\title{
Quantifying Socioeconomic Inequality in Childhood Obesity
}

\author{
Justus Laugwitz \\ Mark Mitchell \\ Patricio Valdivieso Massa *
}

This version: November, 2020

Link to latest version

\begin{abstract}
We use longitudinal data on 11,000 UK-born children to examine the relationship between parental weight and income and children's overweight across childhood. We find that children are three times as likely to be overweight or obese at 14 if they have an obese parent. Irrespective of their parents' weight, children in the poorest $20 \%$ of families are twice as likely to be overweight or obese. These relationships persist through childhood, strengthen over time, and are impervious to observed behavioural differences between groups. This suggests that differences in shared social and economic circumstances across childhood lead to the emergence of stark inequality in childhood obesity across the income distribution by age 14 .
\end{abstract}

Keywords: Childhood obesity, health, inequality, intergenerational transmission JEL codes: I0, I12, I14, J13

*Laugwitz: The University of Edinburgh justus.laugwitz@ad.ac.uk; Mitchell: The University of Edinburgh and the Fraser of Allander Institute, mark.mitchell@ad.ac.uk; Valdivieso Massa: Heriot-Watt University, p.valdivieso_massa@hw.ac.uk. We are grateful to Vana Anastasiadou, Steve Dieterle, Otto Lenhart and Andy Snell for helpful comments and dicsussions. 


\section{Introduction}

The prevalence of childhood obesity around the world has risen dramatically over the past three decades. The World Health Organization (WHO) estimates that the proportion of children and adolescents who are overweight or obese around the world has increased from $4 \%$ to $24 \%$ since $1975 .{ }^{1}$ In 2016 , it is estimated that roughly $18 \%$ of school age children in the USA were obese, whilst in England one fifth of children are obese upon beginning secondary school (Hales et al., 2017; NHS Digital, 2019). In both countries, being from a disadvantaged area or having an overweight parent is highly correlated with childhood obesity (Ogden et al., 2018; NHS Digital, 2019). The consequences of obesity are acute. Childhood obesity is associated with reduced physical health and mental health, reduced skill accumulation and academic performance, and a lower quality of life (Cawley and Spiess, 2008; Sahoo et al., 2015). Obese children are significantly more likely to be overweight or obese in adulthood, and by adulthood, obesity is linked to reduced productivity, including lower wages, and poorer physical and mental health. ${ }^{2}$ Overweight and obese adults also live shorter lives (Peeters et al., 2003), a fact recently brought into focus by the high rate of serious illness and mortality among those classified as obese during the Covid-19 pandemic (Public Health England, 2020; Lighter et al., 2020). Obesity has therefore become an important channel through which disadvantage is transmitted across generations.

There is much still to be understood about the economic factors that have given rise to inequality in obesity. This is in spite of the emergence over the past two decades of a wide literature on the childhood origins of inequalities in important components of human capital, including health (Currie and Almond, 2011; Heckman and Kautz, 2012; Almond et al., 2018). Obesity is a distinct adverse health problem, and one whose "development" is almost surely linked to social and economic circumstances in a similar manner as other broad aspects of human capital (e.g Cunha and Heckman (2007, 2008); Cunha et al. (2010)). Our main aim in this study is to establish empirical facts about intergenerational and income gradients in overweight and obesity. We use the Millennium Cohort Study (MCS) - a cohort of roughly 11,000 children born in the UK between 2000-2002 - to model the probability a child is overweight or obese at the ages of $3,5,7,11$, and 14 based on both their contemporaneous socioeconomic conditions and those when they were 9 months old. By doing so, we quantify the strength of the relationship between early conditions and the likelihood children become overweight or obese, and how it evolves over childhood.

We establish three salient features of the relationship between early conditions and childhood overweight and obesity. First, we find that parental income and weight at birth largely predict whether or not a child is overweight or obese at age 14: children who had an obese parent at 9 months of age in both the richest and poorest $20 \%$ of families are more than four times as likely to be obese at 14 as those with the same income who did not. Further, we find that irrespective of their parents' weight, children in families in the bottom $20 \%$ of the income distribution when they are 9 months old are two times as likely to be obese at 14 than those in families in the top $20 \%$. Second, the relationships

\footnotetext{
${ }^{1}$ https://www.who.int/news-room/fact-sheets/detail/obesity-and-overweight

${ }^{2}$ Childhood and Adulthood obesity: Ebbeling et al. (2002); Reilly et al. (2003); wages: Cawley (2004); Baum and Ford (2004); Han et al. (2009); physical and mental health: Mokdad et al. (2003); McElroy et al. (2004); Scott et al. (2008); Dixon (2010);
} 
between family income, parental weight, and the likelihood a child is overweight or obese holds up at every age for which we have data. Moreover, these relationships strengthen over time, to the extent that the gap in the rate of overweight and obesity between children in the bottom $20 \%$ and top $20 \%$ of the income distribution triples between the age of 3 and 14. This age gap is even more pronounced between those with an obese and normal weight main parent, where the difference in the probability of obesity quadruples between the age of 3 and 14 (18 \% - 27\% and 13\% - 37\%). Third, we show healthy behaviour - measured by reported dietary and exercise habits - also differs across income levels and parents' weight at each of these ages, and that some healthy behaviour is associated with a decreased likelihood of overweight and obesity in later childhood, between 11-14 years old. However, observed differences in healthy behaviour between income groups do not explain the observed obesity gap between them.

Our results add to a body of work from epidemiology and the social sciences that has established correlations between socioeconomic status, parents' weight and children's weight across various stages of childhood. ${ }^{3}$ We build on this work in two ways. First, our analysis quantifies socioeconomic and intergenerational gradients explicitly in the onset of overweight and obesity across five different ages. This allows us to analyse how they change over the whole of childhood. Second, we examine how circumstances at 9 months of age predict obesity at age 14. Many studies concerned with these relationships concentrate on correlations at one or two points in time, meaning they are unable to observe how and when they emerge or the extent of their persistence. ${ }^{4}$ We also show that differences in the diet and exercise related home environment exist across childhood, adding to the growing evidence as to the disparities in aspects of children's home-lives that lead to the emergence of socioeconomic gradients in human capital (e.g Carneiro et al. (2013), Cunha et al. (2013), Attanasio et al. (2019)). Again, our results extend findings from similar studies in epidemiology that have shown evidence of the relationship between socioeconomic status and healthy behaviour at various points in the early years (e.g Reilly et al. (2005), Goisis et al. (2016)) by considering the healthy environment across multiple stages of childhood.

Importantly, the relationships we document suggest that the recent rise in childhood obesity is largely an economic problem. Parental income and weight do not cause children to become overweight or obese (over and above any genetic component of body composition), but the fact that we observe such strong correlations shows the extent to which they are associated with unobserved behavioural and environmental factors that do. It is likely common knowledge that a healthy diet and regular physical activity are required to maintain a healthy bodyweight, and it is unlikely that two parents from opposite ends of the income or weight distribution would not be aware of this. However, our results show that these parents do not appear to follow these principles to the same extent, suggesting that there are different shared circumstances across either distribution which underpin the relationship between income and weight - circumstances that could encompass a wide range of cognitive, psychological and

\footnotetext{
${ }^{3}$ For example, birthweight (Currie and Hyson, 1999; Currie, 2009); early weight gain Griffiths et al. (2010); and Body Mass Index (BMI) at different stages of childhood (Crossman et al., 2006; Ludwig et al., 2013; Costa-Font and Gil, 2013; Goisis et al., 2016).

${ }^{4}$ For example, Goisis et al. (2016) use the MCS to analyse the relationship between socioeconomic status and children's weight, but only using data from two rounds, ages 5 and 11. Nader et al. (2006) evaluate the persistence of overweight/obesity over time in a cohort of US children born in 1991, but they do not focus on socioeconomic disparities.
} 
financial "constraints". For example, Cawley $(2010,2011)$ discuss the role of economic mechanisms, suggesting that - among other factors - cheaper food, increases in maternal employment and time-saving technology have played a part in the rise of childhood obesity. From a policy perspective, Downs et al. (2009) and Loewenstein et al. (2012) have discussed the psychological causes of the rise in unhealthy dietary choices - for example, present bias. Similarly, a review of the evidence on psychosocial stressors in the household by Gundersen et al. (2011) shows that there is evidence that measures of family closeness, financial stress and maternal physical and mental health are all correlated with the likelihood a child is overweight or obese. To understand how they have contributed to the socioeconomic inequality that we show exists in childhood obesity, however, a greater understanding of how these factors affect families differently is required.

The economics literature has seen significant progress toward building an understanding of how many social and economic factors act to shape parents' investments in their children's development, and how differences in investments lead to the emergence of early inequality in skills (e.g Cunha et al. (2010)). Many of the concepts in this literature straightforwardly extend and are well-suited to conceptualise many aspects of the relationship between family background, the home environment and children's weight. For example, recent research has focused on beliefs about the returns to "investments" in child development (Cunha et al., 2013; Attanasio et al., 2019), even eliciting that parents with lower levels of education systematically underestimate the importance of healthy habits for their children (Biroli et al., 2020). This branch of literature has also analysed the effect of parents' human capital, networks and neighbourhoods, economic and financial constraints and government social security policy on early inequalities in development. ${ }^{5}$ All of these factors are likely to affect the emergence of gradients in overweight and obesity to some extent. Understanding how and to what extent they do can broaden understanding of the interaction between the environment and weight across childhood, and help inform policy targeting inequality in obesity.

The results of this paper are descriptive. We do not focus on causal relationships, or the inevitably complex dynamics of the emergence of overweight and obesity that result in the emergence of inequality. Instead, we seek to lay out some facts about socioeconomic inequality in childhood obesity, to highlight the strength of the relationship between family circumstances and a key component of health. While we do not identify the causes of childhood obesity, the results show that there are many open questions for future research. For policy, the magnitude, persistence and strengthening of the relationship we find between socioeconomic background and children's weight suggests two things. First, that the eventual emergence of inequality in childhood overweight and obesity could perhaps be curtailed through interventions targeted before age 3 , but that policy interventions would have to consider conditions across all ages. Second, they suggest that such interventions would benefit from being designed to understand and improve the social and economic conditions faced by disadvantaged familes.

The remainder of this paper is structured as follows. Section 2 introduces the data and presents evidence on the effect of early conditions on overweight and obesity at age 14; Section 3 then estimates how income and parents weight affect the likelihood a child is overweight or obese over different stages

${ }^{5}$ Currie and Almond (2011) and Almond et al. (2018) provide two comprehensive reviews of the literature on childhood circumstances and socioeconomic outcomes in later life. 
of childhood; Section 4 examines the relationships between family background, healthy behaviour and overweight and obesity in children; and Section 5 concludes with a discussion of the results.

\section{The Effect of Conditions at Birth on Overweight at Fourteen}

\subsection{Defining Overweight and Obesity Across Childhood}

Whether or not an individual is overweight or obese is defined by placing their BMI - the ratio of their weight to height squared - relative to a threshold. For adults, a BMI of between 25 to 29.9 is considered to indicate being overweight, and between 30 to 39.9 to indicate obesity. Severe, or morbid, obesity is consistent with a BMI of above 40. These thresholds apply at all ages after 18.6 For children, thresholds are not fixed given that they experience large growth through childhood and adolescence. This means that the distribution of both height and weight changes dramatically over these periods, as do the appropriate thresholds for defining overweight and obesity. At each age in our analysis, we define overweight and obesity according to the International Obesity Task Force (IOTF) thresholds (Cole et al., 2000), shown in Appendix Table A1. These thresholds differ for boys and girls and are defined for children above the age of 2 by estimating growth curves consistent with a BMI of 25 and 30 at age 18 respectively. There are alternative BMI thresholds derived by Cole et al. (1995), however these define overweight and obesity relative to estimates of the distribution of BMI among UK children in 1990. We favor using the IOTF thresholds to those of Cole et al. (1995) because the bulk of our analysis is interested in the relationship between the weight of children and their parents - overweight/obesity for the latter is defined according to having a BMI above 25/30. The IOTF definitions are also stricter that those of Cole et al. (1995) in that they result in lower rates of overweight and obesity in children. ${ }^{7}$

Using these age-specific definitions of obesity circumvents many of the issues that arise when comparing raw measures of weight over time at young ages, however two common criticisms of obesity measures as defined by BMI persist. Firstly, BMI does not consider body types. As a result, two individuals could be classed as overweight or obese although having very different body compositions a BMI in the overweight range gives no indication as to whether the reason for being overweight is excess adipose or muscle tissue. While this shortcoming must be considered with the BMI of parents, we consider it less likely to cause differences in children given there are far fewer external factors and lifestyle choices affecting their body composition (i.e exercise habits, hobbies etc.). Secondly, when defining obesity by a cutoff, we are not creating a variable that perfectly indicates healthy weight and unhealthy weight. It is not necessarily the case that being below the threshold indicates a better outcome for a child. For example, a child might be severely underweight and classified as a zero in the binary definition of obesity.

Much of our analysis focuses on determining the relationship between household and parental characteristics and overweight and obesity among children. Given overweight and obesity are defined

\footnotetext{
${ }^{6}$ See the WHO definitions: https://www.who.int/topics/obesity/en/ and https://www.worldobesity.org/about/aboutobesity/obesity-classification.

$77 \%$ vs $20 \%$ for obesity at age 11 based on data from children in all state maintained schools (NHS Digital, 2019). Similar national figures for other nations of the UK are not available.
} 
relative to BMI thresholds, this analysis focuses on ages at which measures of both height and weight are available; in our data this is from age 3 onwards. The data on birth weight and weight at 9 months of age are only used as explanatory variables for children's weight when appropriate. It is also not common to describe toddlers under 2 years old as "obese", but rather as under or overweight relative to their peers. Consequently, Cole et al. (2000) only provide obesity and overweight thresholds for ages 2-18 and we do not use the birth and 9 month data to define obesity. ${ }^{8}$

\subsection{Data and Sample}

We use detailed longitudinal data on roughly 11,000 UK born children who took part in the Millennium Cohort Study (MCS). At the time of writing, the MCS survey has 6 waves, the first of which was conducted between June 2001 and January 2003 when the children were aged 9 months, with five follow-ups at ages 3, 5, 7, 11 and $14 .{ }^{9}$ The survey contains information on the children's family background, home environment and health at each age. It also collects detailed information on the weight and height of parents in all but its last round. Given that our interest is the relationship between parents' and children's weight across the entire period of the study, we would like to extend our analysis to this round. We therefore use either parents' weight from the second to last round (age 11) or as predicted based on their weight in all previous rounds. Although neither will perfectly capture parents' weight at age 14, it does allow this extension and for us to compare results under two assumptions. Appendix A.5 describes how parents' weight was predicted.

The MCS is administered to a "main parent" as opposed to being explicitly aimed at the children's mothers. As a result, in theory, the survey can be completed by either the mother or the father of a child at each age. In practice, however, the main parent is almost exclusively the mother: $99.85 \%$ and $94 \%$ of main respondents were the mothers at ages 9 months and 14 years respectively. The MCS over-sampled children from disadvantaged backgrounds, and so is not nationally representative by design. ${ }^{10}$ There is also considerable attrition in the study - there are almost 8,000 less respondents at age 14 than at 9 months.

An important feature of this attrition is that families from disadvantaged economic backgrounds drop out of the study disproportionately more than those from wealthier backgrounds. Appendix Table A2 provides a statistical summary of the the sample at each age. Columns (5) and (6) are identical except for the measures of parents' overweight and obesity; column (5) uses parents' weight from the previous (age 11) round, and column (6) their predicted weight. A higher share of parents and children become overweight or obese over time, indicating that body composition changes for both over the

\footnotetext{
${ }^{8}$ In the few cases where we define relative weight and 9 months or birth, we instead use definitions of under- and/or over-weight. We consider a weight of less than 2,500 grams at birth as to indicate low birth weight, and a weight of 2 standard deviations below/above the mean weight in the sample as indicating under/overweight at 9 months - both of which are internationally recognised thresholds that are widely used in both epidemiological and economic studies of weight. See (WHO, 2018) for the definitions of underweight at these early ages.

${ }^{9} \mathrm{MCS}$ sampling was carried out so as to sample children of the same age at interview. There are some exceptions to this. The age of cohort members at wave 1 ranges from 6-12 months, however the average age is 9.2 months with a standard deviation of only 0.5 months - 16,500 out of 18,552 (excluding twins and triplets) cohort members are aged 9 or 10 months.

10"Importantly, certain sub-groups of the population were intentionally over-sampled, namely children living in disadvantaged areas, children of ethnic minority backgrounds and children growing up in the smaller nations of the UK." https://cls.ucl.ac.uk/cls-studies/millennium-cohort-study/
} 
period of the study. The sample also gets richer on average, with the income distribution at 9 months becoming skewed towards the higher income quintiles by age 14. This is in spite of it initially being skewed in the opposite direction. The ethnic composition of the sample remains relatively similar across rounds, and by age 14 there are less parents with no qualifications than in the initial wave.

The change in composition of the sample is due to both lower-income families dropping out, and movements along the distribution of those who remain in the sample. Table A3 shows the attrition rate by the initial income quintile of the family. Families from the lowest quintile drop out of the sample with a $50 \%$ probability by wave 6 , compared to $29 \%$ for the highest quintile. Furthermore, the remaining families from all quintiles are much more likely to move up the income distribution than down. In Table A2 we can see that the lowest income quintile makes up only $16 \%$ of the sample by wave 6, whereas the highest income quintile makes up 24\%. Looking at column (1) of the same table, the MCS sampled 25\% from the lowest quintile and only $16 \%$ from the highest quintile, meaning this is a substantial change in the sample composition. Furthermore, overweight and obese parents were also more likely to drop out of the MCS sample by the final wave than normal weight parents. Table A4 shows the same transition matrix as Table A3 but for parents weight category at 9 months and 11. Roughly $54 \%$ of obese or morbidly obese parents dropped out of the study between rounds 1 and 5 . This is compared to slightly less than a $50 \%$ of parents whose weight was in the overweight range, and $47 \%$ of those whose weight was normal in the first round.

It is possible that this attrition is based solely on the observables the MCS measures. However, in light of the substantial movement up the income distribution we observe for the remaining sample, this seems implausible. Partially that is expected as the working members of the families gain an additional 14 years of experience. However, this is unlikely to be the only explanation in light of the UK's low income mobility, particularly for low-earners or those from disadvantaged areas - two sub-populations over-represented in the initial the MCS. ${ }^{11}$ More plausibly, there is likely a correlation between those unobserved heterogeneities that influence workplace productivity and those that impact how likely you are to attrite from the sample. This is particularly worrisome as workplace productivity is a known correlate to obesity and overweight, which in turn is positively correlated with children's weight, and suggests that the final sample consists of overachievers. With this observation in mind we conclude that the restricted MCS sample likely suffers from self-selection bias in our primary variables of interest - obesity and income. The nature of the suspected bias would imply that any raw results we obtain understates the relationship between income and overweight/obesity and might be better interpreted as conservative estimates of true relationships between income or parents' weight and overweight and obesity in children. To account for the MCS sampling design and the likelihood of attrition, we use sampling weights that adjust for both in our analysis. The weights are the inverse of the predicted conditional probability each child is sampled from the UK population in the initial wave and then remains in the sample. ${ }^{12}$ At its root, this adjustment for attrition relies on the assumption that selection into the sample can be predicted based on observable characteristics. If there are unobservable differences between those who do and do not remain in the sample like those we discuss above, however,

\footnotetext{
${ }^{11}$ See for example a recent report by Carniero et al. for the UK's Social Mobility Commission.

${ }^{12}$ Hansen et al. (2014) provides detail on how non-response weights are calculated.
} 
this method will not fully correct our estimates to be representative. We bear this in mind throughout and in some cases compare our main estimates with unweighted results to asses the potential impact of attrition.

\subsection{Early Conditions and Overweight}

We begin with the observation that circumstances very early in children's lives strongly predict whether or not they will be obese or overweight in adolescence.

$$
\operatorname{Pr}\left[W_{i, 14}=1 \mid \mathbf{\Omega}\right]=F\left(\delta_{14}+\boldsymbol{\gamma}_{14} \mathbf{Y}_{i, 9 m}+\boldsymbol{\rho}_{1} 4 \mathbf{M P W} \mathbf{W}_{i, 9 m}+\mathbf{x}_{\mathbf{i}, \mathbf{9} \mathbf{m}} \boldsymbol{\beta}_{i, 14}+\varepsilon_{i, 14}\right) \quad \text { for } W_{i, 14} \in\{O W, O B\}
$$

In $1, \boldsymbol{\Omega}=\left(\mathbf{Y}_{i, 9 m}, \mathbf{M P W}_{i, 9 m}, \mathbf{x}_{i, 9 m}\right)$ contains all information on the right-hand-side of the equation; $F()$ is the logistic cumulative density function; $\boldsymbol{Y}_{i, 9 m}$ is a vector of dummies indicating whether or not equivalised household income ${ }^{13}$ at 9 months of age is in one of five quintiles; $\mathbf{M P W} \mathbf{W}_{i, 9 m}$ is a vector of dummies indicating whether the main parents' weight was in the normal, overweight or obese or morbidly obese (hereafter, obese for brevity) range when the child was 9 months old; $\mathbf{x}_{\mathbf{i}, 9 \mathbf{m}}$ is a vector of control variables; and the outcomes $O W_{i, 14}$ and $O B_{i, 14}$ are whether a child is overweight or obese at 14 respectively. In $\mathbf{x}_{\mathbf{i}, 9 \mathbf{m}}$, we include controls for gender, birth weight, weight gain between birth and 9 months, ethnicity, the number of siblings in the household and the parent's age at birth, level of education, and whether or not they have a long-term illness.

Appendix Table A5 shows the predicted marginal effect of family income and whether or not the main parent is overweight or obese on the probability of children being obese (column (1)) or overweight (column (2)) at age 14, holding all other control variables fixed at their sample means. Being in the lowest as opposed to the highest quintile of the income distribution at 9 months is associated with a 4.4 and 7.6 percentage point increase in the likelihood of being obese or overweight, respectively. Similarly, having a main parent who is obese at the same age is associated with respective increases of 11.7 and 18.6 percentage points. These effects are large relative to the probability of each outcome: the bottom of Table A5 shows that the expected conditional probability of being obese or overweight is 0.043 and 0.169 respectively. Columns (3) and (4) of Table A5 also show analogous results, but unweighted for attrition or the MCS sampling strategy. They are in line with our intuition in the previous section as to the effect sample design and attrition might have on results - the effects of income quintiles in columns (3) and (4) are less pronounced. ${ }^{14}$

As might be expected, the likelihood of a child in the bottom of the income distribution being overweight or obese is relatively high. Calculated from the same regressions used to obtain the marginal effects in Table A5, Figure 1 shows the difference in the conditional probability of children being obese (panel (a)) or overweight (panel (b)) across the lowest and highest income quintiles conditional on

\footnotetext{
${ }^{13}$ In the MCS, household income is equivalised using the OECD equivalisation scales, which adjust family income for family size and composition. Hansen et al. (2014) provide detail on the OECD equivalisation used in the MCS, and how it compares to other commonly used scales.

${ }^{14}$ Note here that although when weighting we use all available observations, there are fewer observations in the weighted regressions in Table A5. This is because the restricted (i.e to those available in the initial and last waves) and unrestricted samples are identical, and a missing value for the weighting variable.
} 


\section{Figure 1: Predicted conditional probabilities of being obese and overweight at 14}

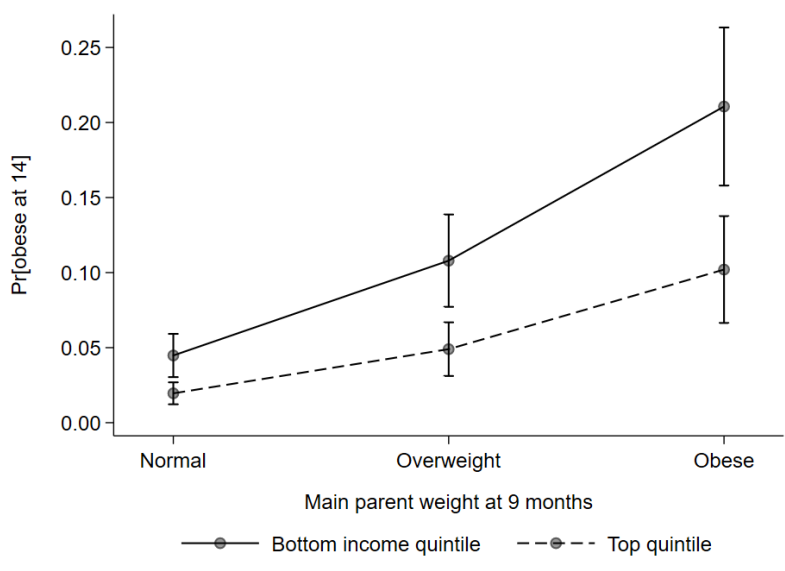

(a) Obese at age 14

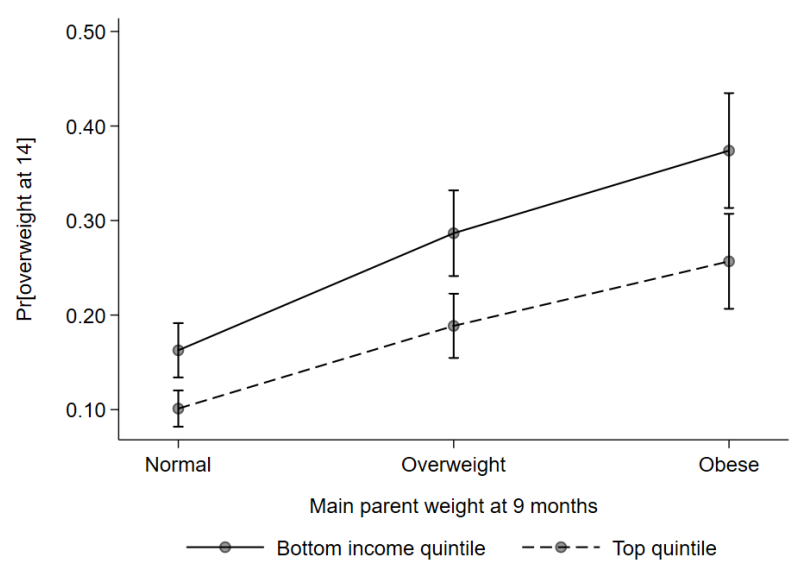

(b) Overweight at 14

Note: Each panel shows the predicted conditional probability of being overweight or obese at 14 under the values of either income or weight of the parent indicated on the $\mathrm{x}$ axis. All other variables are fixed at their mean. Dots represent estimated conditional probabilities and vertical lines their $95 \%$ confidence interval. The regressions from which they were calculated controlled for children's gender, birth weight, weight gain between birth and 9 months, whether they have a long-term illness and the number of health conditions reported, ethnicity, the number of siblings in the household, and the parent's level of education and whether they have a long-term illness. All observations are adjusted for the probability of attrition and being sampled, see (Hansen et al., 2014). Appendix Table A5 shows the full results.

having a parent whose weight is in the normal, overweight or obese range. Figure 1(a) shows two contrasts. Firstly, children at both ends of the income distribution who have an obese parent are over four times more likely to be obese than those whose parents' weight are in the normal range. Those with an overweight parent are almost three times as likely to be obese relative to the same group. Second, irrespective of their parent's weight those in the bottom $20 \%$ of the income distribution are consistently twice as likely to be obese at 14 than those in the top 20\%. Although the slopes in Figure 1(a) are slightly different across income quintiles, the difference is not statistically significant. We also estimate versions of 1 that include interactions of income and parental obesity, however these interaction effects were not statistically significantly different from zero. Together, these results do not provide any evidence that the likelihood a child will be obese given their parent is obese differs significantly between those in the top and bottom of the income distribution. Rather, they suggest that it is differences in income, and the wider environment it captures, that result in higher rates of obesity among the relatively poor children.

To understand when these gradients emerge over childhood, Appendix Figure A1 plots the proportion of children in the top and bottom quintile of the income distribution who are overweight (panel (a)) and obese (panel (b)) at each age. It shows that at all ages between 3 and 14 a larger proportion of those in the bottom quintile are classified as either. The difference stays relatively stable between the ages of 3 and 7, but thereafter an increasing number of those in the bottom income quintile are classified as overweight or obese, meaning that by age 14 the difference is stark.

Importantly, and as we noted in the discussion of our sample, parents' income and weight change over time. It is plausible that the strong correlation between the parent's weight at 9 months and the 
child's weight at 14 years is due to initial conditions linked to the parent's weight. At the same time, their weight, or how it changes at later stages of childhood, influences the child's weight at adolescence. Figure 2 shows the predicted conditional probability that a child is overweight or obese at 14 depending on whether the parent changes their weight (panel (a)) or income (panel (b)) category or not. In panel (a), we can observe a significant gradient: those who either were originally obese and were not by 14 or vice versa were significantly more likely to have an overweight/obese child at 14 . However, if the parent was obese at both points the probability is significantly larger than if only one condition is present. This evidence points to the importance of both initial conditions as well as conditions later in childhood in determining the likelihood a child becomes overweight or obese. If, for example, only initial conditions mattered then we would not expect children of parents whose weight was normal at 9 months but in the range of overweight or obese at 14 to be significantly more likely to be overweight than those whose weight was normal at both ages. Similarly, if only later conditions mattered we would not expect that switching in the opposite direction would result in a significantly different probability of children being overweight or obese relative to those parents who are in the normal/overweight weight at both ages.

Of course this type of comparison does not necessarily consider the magnitude of changes in BMI that led to switches. For example, an increase in BMI from 20 to 31 is treated that same as an increase in BMI from 29-31 - both result in a change from being in the normal/overweight to the obese range. With this in mind, we found the trend from Figure 2 to be robust to excluding those whose BMI only changes marginally: restricting the analysis to only those whose category switched as a result of an increase in BMI of, for example, 5 or greater, the picture is broadly unchanged.

Figure 2(b) shows the difference in likelihood a child is overweight or obese conditional on whether or not their family moved up or down the income distribution in the lowest and highest income quintiles. Relative to those who stayed in the same position, the probability a child is overweight or obese is slightly higher among those whose families moved down the distribution, and slightly lower among those who moved up. These differences are not statistically significant, however, meaning we cannot infer a strong correlation between moving quintiles and children being overweight or obese. Two broad messages therefore emerge from Figures 2(a) and 2(b). Firstly, both initial conditions and those thereafter matter for the the likelihood a child is overweight or obese. Secondly, the difference in this likelihood is greater when comparing initial versus later weight than income conditions. Again, it is not that we would like to infer causal effects of changes in weight or income category here, but rather understand how group characteristics are correlated with overweight and obesity in children. This, in turn, allows us to understand what underpins our results in following sections. 


\section{Figure 2: Predicted conditional probabilities of being overweight or obese and overweight at 14, given changes in parents' weight and income}

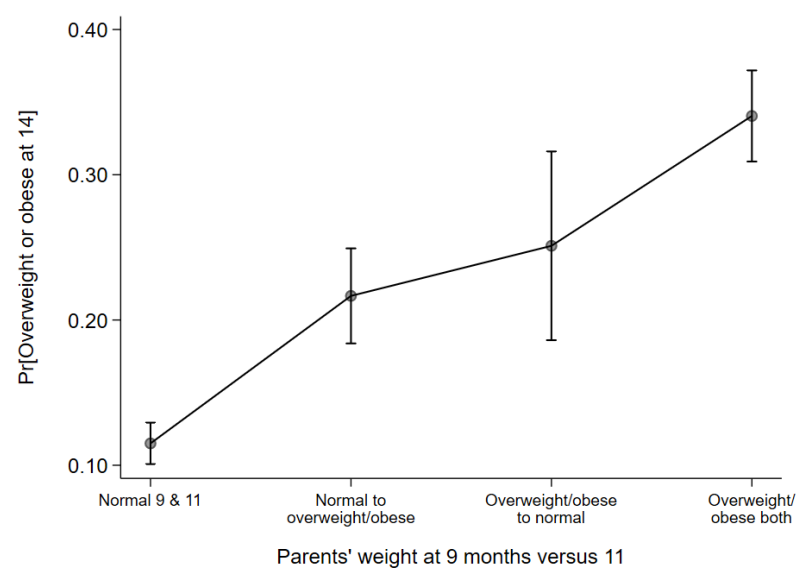

(a) By changes in parents' weight

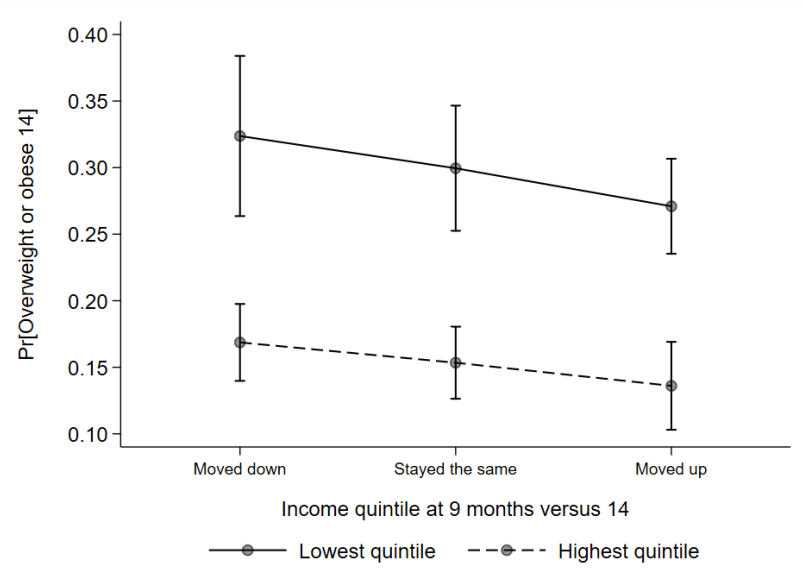

(b) By movements across the income distribution

Note: No parents in the sample moved from classified as obese at 9 months to a normal/overweight at 14. Each panel shows the predicted conditional probability of being overweight or obese at 14 under the values of either income or weight of the parent indicated on the $\mathrm{x}$ axis. All other variables are fixed at their mean. Dots represent estimated conditional probabilities and vertical lines their $95 \%$ confidence interval. The regressions from which they were calculated controlled for children's gender, birth weight, weight gain between birth and 9 months, whether they have a long-term illness and the number of health conditions reported, ethnicity, the number of siblings in the household, and the parent's level of education and whether they have a long-term illness. All observations are adjusted for the probability of attrition and being sampled, see (Hansen et al., 2014). 


\subsection{Height, Weight and healthy behaviour Across Childhood}

Given that overweight and obesity are ultimately defined by relative weight and height, Appendix Figures A1(c) and A1(d) also show how these two characteristics evolve in the MCS over time respectively. For comparison over time, the figure plots the average, height (panel (c)) and weight (panel (d)) z-scores at the ages which we have data. Together the two panels show that the prevalence of overweight and obesity at the bottom of the income distribution relative to the top results from two features of the groups. Firstly, children in the bottom quintile are relatively shorter, on average, at every age, and that this gap widens over time. Secondly, although the same group are much lighter very early, by age 3 their weight converges very close to those in the top quintile. After age 7 weights diverge and those at the bottom of the income distribution become relatively heavier, and those at the top relatively lighter. ${ }^{15}$ Appendix Figures A3(a) and A3(b) also show that there are pronounced gaps in obesity and or overweight respectively when children are grouped by whether or not their main parent is obese.

These descriptive trends raise questions about what occurs or changes that leads to the emergence of gaps in obesity across income levels. The age at which these gaps begin to widen, between the ages of 7 and 11, undoubtedly coincides with a time of increasing self-determination for children - by age 11 the children in the MCS sample (a UK-based study) are soon to be entering their high school years. It is likely that over the adolescent years, children begin to engage in more obesogenic - obesity causing - behaviours themselves outside their homes (Nelson et al., 2006; Brodersen et al., 2007). It is also possible that parents' behaviour changes at this time, and that as children get older they reduce the enforcement of lifestyle choices. At the same time, it could be the case that at the onset of puberty the accumulation of lifestyle and/or genetic factors begin to take effect as children begin the largest period of growth they will experience outside of gestation.

If lifestyle choices have an intergenerational component, then it is very likely that all three of these factors are intertwined. Although we do not fully pick them apart here, Appendix Figure A4 shows that the gap between rates of obesity also widens for parents over time. Initial small differences in the proportion considered obese (panel (b)) widen such that at children's age 14 parents at the bottom of the income distribution are far more likely to be classified as such. Although the gap does not widen over time, parents in the bottom income quintile are consistently more likely to be overweight across the same period pPanel (b)). This suggests that relatively poor parents are not only more likely to be obese when children are born, but also much more likely to become so at later ages, and that the trends in children's weight across childhood are somewhat tied to the unequal changes in parents' weight: considered alongside Figure 2(a), these findings show that low-income parents are more likely to become obese and that these changes appear to be linked to the likelihood that children also do. There are of course many aspects of family environment which are correlated with income and parents' weight, such as general health and illnesses, household composition and education that might explain the differences and changes in parental weight we have outlined here. We explore this in the next section.

\footnotetext{
${ }^{15}$ Appendix Figure A1 uses income quintiles based on income in each round. The trends are identical, if not even more pronounced, when fixing income at its level at 9 months (Appendix Figure A2)
} 
Ultimately weight gain is a consequence of consuming calories at a surplus relative to calories burnt. Although we cannot measure the caloric intake and expenditure in our data set, we do observe whether children have diet and exercise related healthy behaviour. Appendix Figure A5(b) shows that slight differences in reported healthy behaviour ${ }^{16}$ emerge between children who are overweight and normal weight at age 14 over the span of their childhood. For children who are obese at 14, a similar pattern in the reduction of the proportion of children reporting healthy behaviour emerges, however it is considerably larger and remains large throughout the sample from age 5 onward (Figure A5(b)). Healthy behaviour and weight are of course likely reversely correlated, such that healthy behaviour is linked to lower body weight but higher body weight might increase pressure on the parents and children to engage in healthy behaviour. Appendix Figures A5(a) and A5(b) seems to suggest that the former effect outweighs the latter slightly for overweight children and strongly for obese children.

Figure A6 shows that the lifestyle choices linked to obesity observed in our data are also strongly connected to the intergenerational and socioeconomic correlates of obesity discussed above. Overweight and obese (panel (a)) parents are less likely to introduce healthy behaviour into their children's lifestyle Finally, Figure A6(b) shows that a marked difference in healthy behaviours can be observed across socioeconomic groups. Over $40 \%$ of families in the top $20 \%$ of the income distribution report healthy behaviour at age 14 and around $60 \%$ at age 5 to 11 , consistently 20 to 40 percentage points more than in the bottom income quintile for the same ages. ${ }^{17}$

In summary we describe the following six stylised facts about gradients in overweight and obesity among children. (i) Low-income children are considerably more likely to be overweight at adolescence than high-income children. (ii) This trend is a consequence of both lower height and higher body weight. (iii) Obese parents are more likely to have children who become overweight by adolescence. (iv) Moreover, low-income obese parents are more likely to have overweight children at adolescence than high-income obese parents. (v) Healthy dieting and exercise behaviours are less likely to be observed in (a) children who become overweight by adolescence, (b) children from low-income backgrounds, and (c) children with obese parents. Finally, (vi) the above stylised facts are far more pronounced for children who become obese by adolescence than children who become only overweight. The following sections will explore these facts in more depth.

\section{Socioeconomic Status and Overweight Across Childhood}

So far we have analysed the relationship between initial conditions (at 9 months) and obesity and overweight in children at 14 , and descriptively documented how children's weight evolves across categories of parents' weight and income over childhood. We have not, however, considered the wide range of circumstantial factors that might be driving this relationship at each point in time. In this section we quantify the relationship between income, parents' weight and overweight and obesity in children at each age - 3,5,7,11, and 14 - net of a wide range of family and background characteristics.

\footnotetext{
${ }^{16}$ This measure of healthy behaviour was created using questions asked to the parents in the MCS about the diet/exercise habits of their children. Appendix Table A6(a) describes these questions, and Section 4 describes how we constructed this composite measure in more detail.

${ }^{17}$ See footnote 16.
} 
In specifying determinants of the probability of a child being overweight or obese, our primary interest is in the two transmission mechanisms discussed so far: parents' weight and family income. In a similar fashion to Equation 1, we assume that whether or not a child is classified as overweight or obese at each age is determined as follows:

$$
\operatorname{Pr}\left[W_{i t}=1 \mid \mathbf{\Omega}\right]=F\left(\delta_{t}+\boldsymbol{\gamma}_{t} \mathbf{Y}_{i t}+\boldsymbol{\rho}_{t} \mathbf{M P} \mathbf{W}_{i t}+\mathbf{x}_{\mathbf{i t}}{ }^{\prime} \boldsymbol{\beta}_{t}+\varepsilon_{i t}\right) \quad \text { for } W_{i t} \in\{O W, O B, O W O B\},
$$

where $\boldsymbol{\Omega}=\left(\mathbf{Y}_{i t}, \mathbf{M P W}_{i t}, \mathbf{x}_{i t}\right)$ now contains all contemporaneous information on the right-hand-side of the equation; $F()$ is the logistic cumulative density function; $\boldsymbol{Y}_{i t}$ is a vector of dummies indicating whether or not equivalised household income at age $t$ is in one of five quintiles; $\mathbf{M P \mathbf { w } _ { i t }}$ is a vector of dummies indicating whether the main parents' weight is in the normal, overweight or obese range; $\mathbf{x}_{\mathbf{i t}}$ is a vector of control variables; and the outcomes $O W_{i t}, O B_{i t}$ and $O W O B_{i t}$ indicate whether a child is overweight, obese or either at age $t$. We estimate Equation 2 separately at each age $(t \in\{3,5,7,11,14\})$, and interpret $\gamma_{t}$ and $\rho_{t}$ - the main parameter vectors of interest - as indicating the strength of the relationship between parental income and obesity and children's probability of overweight/obesity at each point in time.

In estimating Equation 2, we are not attempting to estimate the causal relationships between parents' weight and income and children's weight, which would require guaranteeing that both are conditionally uncorrelated with $\varepsilon_{i t}$. Overweight/obesity in children is an anthropometric outcome, meaning that $\varepsilon_{i t}$ is almost surely comprised of both individual heterogeneity that is correlated with these characteristics as well as a purely random component. For our purposes it makes little sense to treat income and parents' weight in a way that represents a search for a causal relationship, given that these two features of the early environment do not necessarily cause obesity, but rather are correlated with unobervables that do. This heterogeneity could capture, among others, aspects of health, the family environment, economic constraints, or psychological or cognitive factors which affect both parents' income and weight, and the likelihood a child is overweight or obese.

We do not explicitly model this heterogeneity here, however we do condition on an extensive range of characteristics in order to control for the effects of health and demographics: in our main specifications, $\mathbf{x}_{\mathbf{i t}}$ contains controls for gender, birth weight, weight gain between birth and 9 months, number of siblings in the household, ethnicity, health conditions and long-term illnesses of the main parent and the child, and the age and education level of the main parent. Doing so captures components of this individual heterogeneity within income and weight groupings with which they are correlated. In estimating $\rho$ we therefore aim to capture the combined behavioural and genetic channel through which parental weight affects the likelihood a child becomes overweight or obese. Our estimates of $\gamma$ s should capture only the behavioural channel through which income affects the same outcome. For example, if the marginal effect of being in the bottom as opposed to the top income quintile is positive, we would infer that the associated increase in probability of being overweight or obese is due to a combination of, for example, economic, cognitive or psychological constraints that induce unhealthy behaviour. If the same were true of our estimate of $\rho$, we could infer that it also captures all of these things, as well 
as any remaining genetic influences. We do not un-pick how any specific factor contributes to these channels or how they change over time but rather focus on the magnitude of these overall correlations: ${ }^{18}$ these give an indication of the extent to which differences in these remaining unobservables across groups affect the likelihood children become overweight. However, in the next section we do examine differences in healthy behaviour over childhood and the extent to which they explain any of them.

Lastly, in Section 2 we discussed how our sample was likely comprised of over-achievers, and that parents who change weight or income classification over time are likely to differ systematically from those who do not. At the end of this section, we therefore examine how initial conditions (at 9 months) affect the likelihood of overweight and obesity net of the effect of contemporaneous conditions.

\subsection{Income and Intergenerational Gradients in Overweight from 3 to 14}

Table 1 reports the marginal effects of MPW and $\boldsymbol{Y}$ on the probability of overweight (panel A), probability of obese (panel B) and the probability of overweight or obese (panel C), using the thresholds presented in Appendix Table A1. Results with the complete set of covariates are reported are in Appendix Tables B2-B4. Given that we do not have information on parents' BMI at age 14, we report marginal effects at age 14 treating parents' BMI in two ways: in column (5) we assume it is constant between 11 and 14, while in column (6) we use predicted values, the estimation of which is outlined in Appendix A.5. ${ }^{19}$

Across all outcomes and all ages there is a large effect of having an obese parent relative to one whose weight is in the normal range. This effect is broadly increasing over time, such that by age 14 having an obese parent increases the probability of a child being overweight or obese themselves by roughly 24 percentage points. Again, this effect is large: it is larger than the estimated conditional probability of being overweight or obese, shown at the bottom of panel C. This appears to be driven by the relationship between parental and child obesity: Panel B shows that across all ages the marginal effect of having an obese parent is greater than the overall estimated conditional probability of being obese, shown at the bottom of the Panel. By age 14, it is 2.5 times as large.

Similarly, the income quintile of a child's family positively affects the probability of being obese or overweight in each period. Panel $\mathrm{C}$ of Table 1 shows the marginal effect of being in the lowest, second, third, and fourth income quintile as opposed to the highest on overweight or obesity is increasing over time, particularly for those in families in the bottom quintile: between ages 3 and 14, this marginal effect increases by around 12 percentage points. The result is a relative effect of around 17 percentage points on the likelihood of being overweight or obese by this age, about $85 \%$ of the overall conditional probability. As was the case with parents' weight, although the broad patterns are similar and result in clear differences by age 14, the effect of income varies in magnitude when considering overweight and obesity separately. Again, the marginal effects on the likelihood of being overweight are large, however

\footnotetext{
${ }^{18}$ In some instances we use the term "correlations" to loosely refer to marginal effects from our logit models. These marginal effects coefficients represent the effect of a change in some explanatory variable on the predicted probability of our binary outcome keeping other covariates fixed, but for the ease of exposition we might at some particular instances refer to these marginal effects coefficients as correlations to accentuate the fact that our estimates do not represent causal effects.

${ }^{19}$ In Table 1 all standard errors are calculated using the delta method, including those using predicted parental weight. These are unchanged when using a bootstrap, however.
} 
Table 1: The determinants of child overweight and obesity across childhood

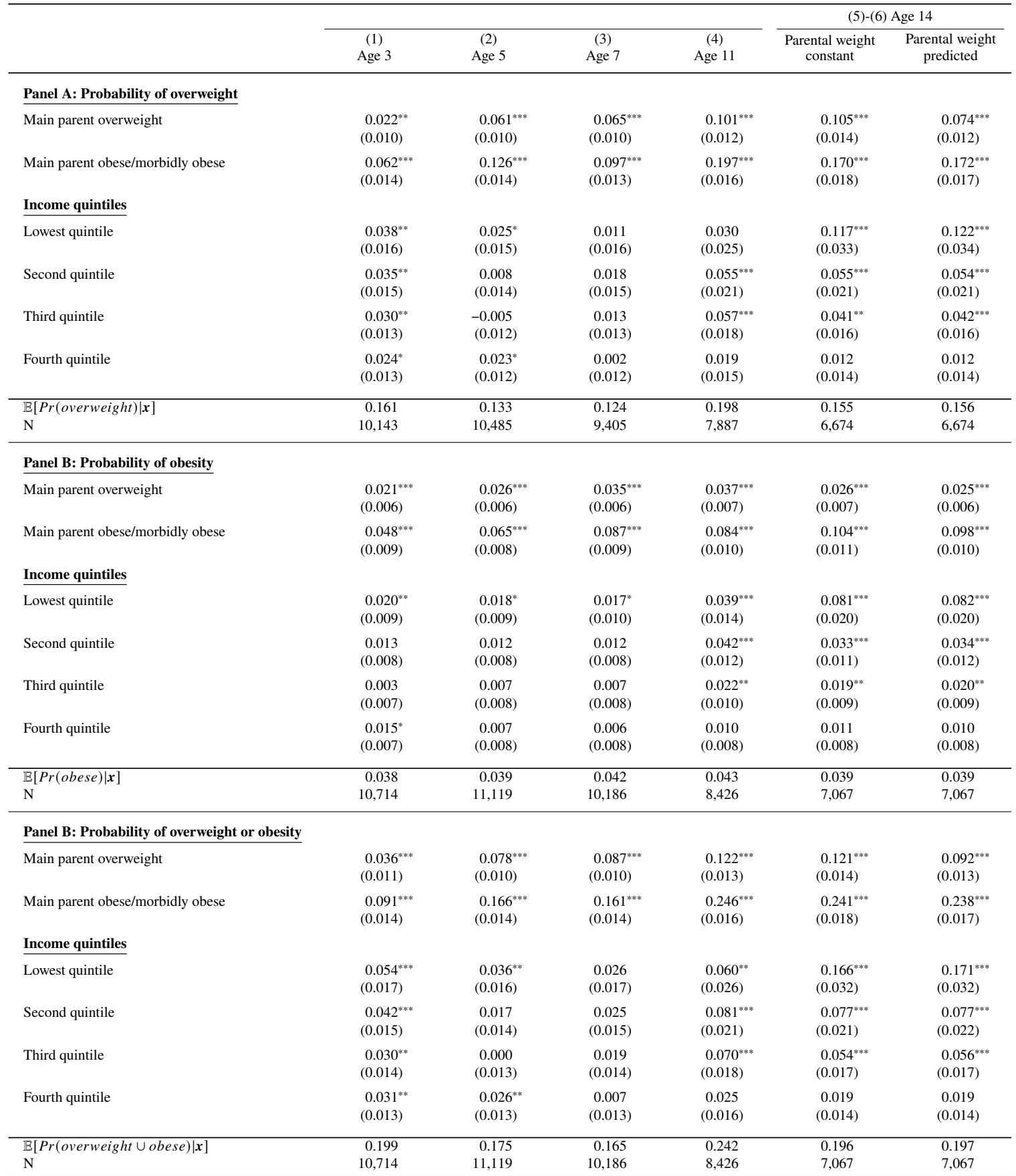

Note: $* * *$ and $* * *$ denote statistical significance it $10 \%, 5 \%$ and $1 \%$ respectively. The outcome in each column is indicated by Panels A-C, and are defined using the the IOTF cutoffs (Table A1). The effects reported are marginal effects obtained after estimating Equation 2 fixing the independent variables at their sample mean. The MCS data do not contain parents' BMI at age 14, so columns 5 and 6 use BMI from age 11 or as predicted to define obesity. The omitted income category is the highest quintile. All observations are adjusted for the probability of attrition and being sampled, see (Hansen et al., 2014). The omitted income category is the highest quintile. The regressions from which they were calculated controlled for children's gender, birth weight, weight gain between birth and 9 months, whether they have a long-term illness and the number of health conditions reported, ethnicity, the number of siblings in the household, and the parent's level of education and whether they have a long-term illness. Appendix Tables B2-B4 show full results. $\mathbb{E}[\operatorname{Pr}($ outcome $) \mid x]$ represents the estimated conditional expectation of each outcome. The main parent is the mother for $99 \%$ of children at 9 months. Ns differ in Panel A because these regressions exclude obese children. Ns differ across columns because of missing data. 
they are more striking for obesity: by age 14 being in the bottom relative to the top of the income distribution is associated with an increase in probability of being obese of 8 percentage points, over double the size of the conditional probability of being obese. Appendix Table B1 shows analagous estimates to those in Table 1 but using the restricted sample and not adjusting for attrition and sampling design. It shows the change in the relationship between parental income and weight and children's weight is less pronounced when not accounting for these two features of the sample. Again this is in line with our previous intuition that the MCS was comprised of overachievers. Of course, we still cannot rule out that there are unobservables which determine selection into the sample further affecting our estimates.

These results imply two things about the relationship between children's weight and parents' weight and income over childhood. Firstly, over and above a rich set of controls they affect the likelihood that children are overweight or obese at every age we study. Second, the relationship between the three strengthens over time, such that the differences in the prevalence of overweight and obesity across parents weight and income at the end of childhood are very pronounced. Figures 3(a) and Figures 3(b) show the predicted probability of being overweight or obese across the top and bottom of the income distribution and whether or not a parent is obese at age 3 and 14. They show the extent to which both gradients increase over time, and the magnitude of the increase. Children in the lowest income quintile are initially about $32 \%$ more likely to be overweight or obese than those in the highest quintile, but by age 14 this gap more than triples and they are over $100 \%$ more (or twice as) likely to be so. Similarly, children who have an obese parent are about 53\% more likely to be overweight or obese themselves at 3 than those who do not, but at 14 this difference increases to over $200 \%$, or more than three times the likelihood. Panel (c) then shows that conditioning on parents' weight being in each of the three categories, children in the lowest income quintle are consistently twice as likely to be overweight or obese by age 14 .

Tables B2-B4 also suggest that various demographic and circumstantial factors affect the likelihood children are overweight or obese across ages. For example, females are consistently more likely to be overweight or obese across all of childhood. ${ }^{20}$ Parental level of qualifications also appears to be important across various ages, and at age 14 having a parent with the highest level of qualification is associated with a 7 percentage point reduction in the likelihood a child is overweight or obese (Table B4). That income has a strong effect over and above education suggests that income groupings, although highly correlated with educational groupings, better capture group characteristics that explain the likelihood of overweight and obesity. Both birthweight and weight gain between 9 months and 3 years of age have a strong, positive marginal effect on this outcome, as well as being overweight and obese separately. The number of siblings consistently has a negative effect on all outcomes, with having an additional sibling in the household being estimated to reduce the probability of becoming overweight or obese (Table B4) by as much as 3 percentage points at ages 11 and 14. The number of health conditions children affects the likelihood they are obese at some ages (Table B3), but not consistently or to a large extent. Similarly, whether or not parents or children themselves have long-term illnesses is not consistently a significant predictor of any outcome. Importantly, Tables B2-B4 show that none of

\footnotetext{
${ }^{20}$ This could also partly reflect differences in thresholds for overweight/obesity.
} 
Figure 3: Predicted conditional probabilities of being obese and overweight at 3 and 14 , by income and parents' weight

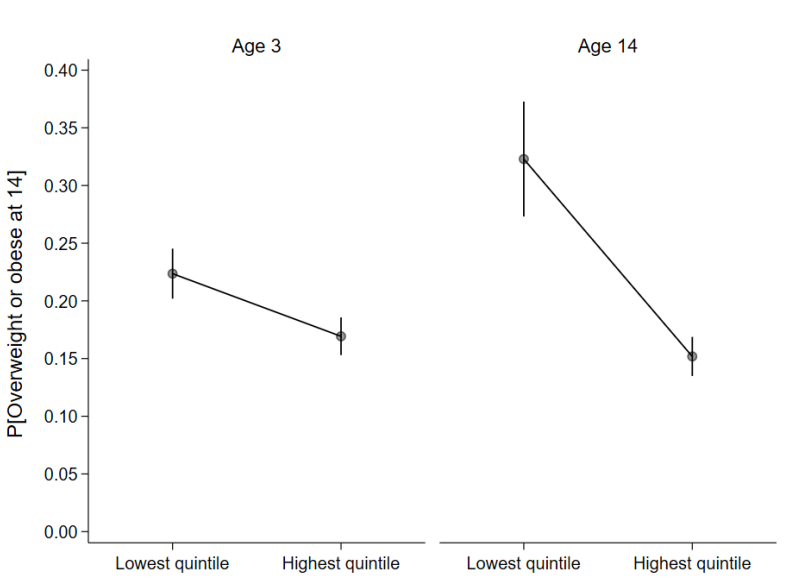

(a) In the top and bottom income quintiles

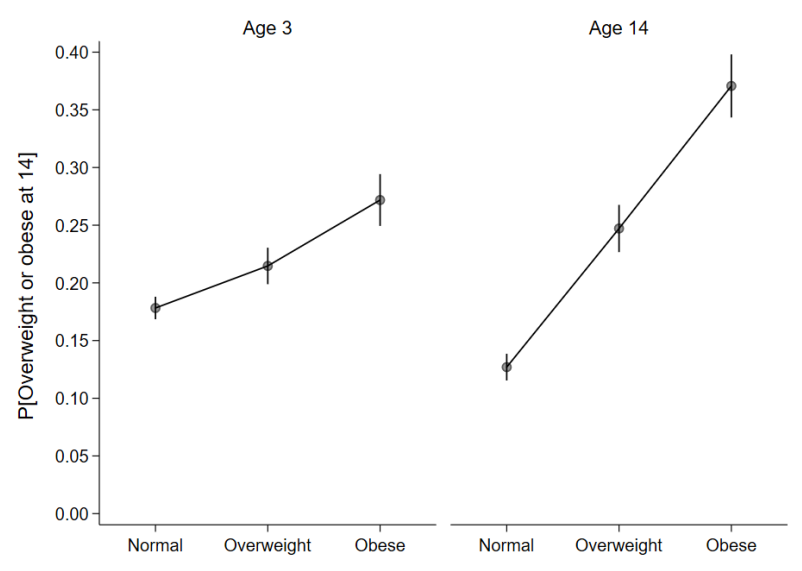

(b) By whether or not the main parent is overweight or obese

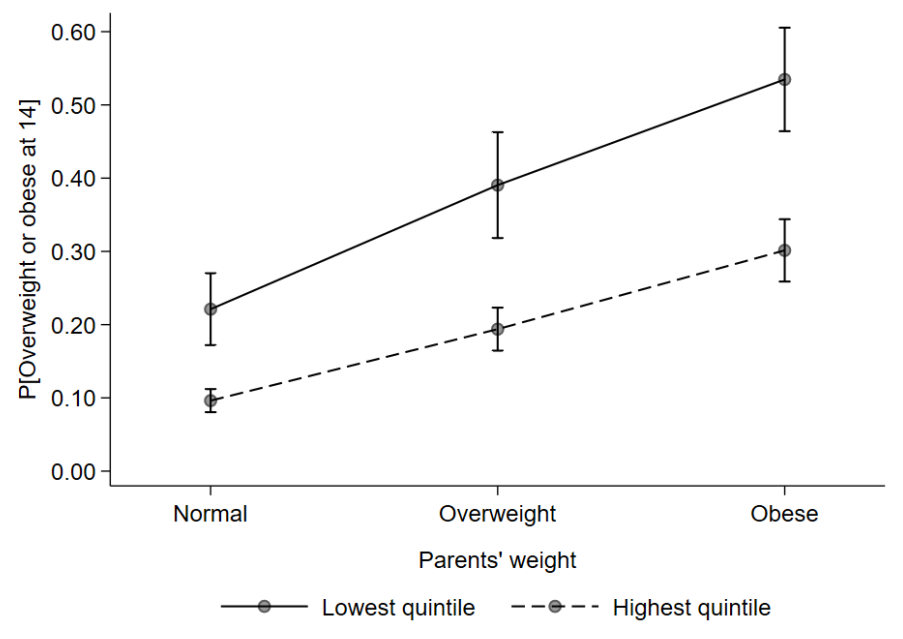

(c) Across income quintiles and parents' weight at 14

Note: Each panel shows the predicted conditional probability of the outcome on their y axis under the values of either income or weight of parents indicated on their $\mathrm{x}$ axis. Probabilities were calculated after estimating Equation 2 at age 3 and 14 for each outcome. Dots represent estimated conditional probabilities and vertical lines their 95\% confidence interval. The regressions from which they were calculated controlled for children's gender, birth weight, weight gain between birth and 9 months, whether they have a long-term illness and the number of health conditions reported, ethnicity, the number of siblings in the household, and the parent's level of education and whether they have a long-term illness. All observations are adjusted for the probability of attrition and being sampled, see (Hansen et al., 2014). Appendix Tables B2-B4 show full results. All other variables were fixed at their mean.

these demographic or health-related factors explain the gaps in childhood obesity across the parental income or weight distribution, and suggest that varying social, economic, and psychological factors (captured in the $\gamma \mathrm{s}$ ) across the two play a large role in determining children's weight. 


\subsection{Initial Versus Contemporaneous Conditions}

As we outlined above, the effects in Table 1 are estimates of the overall relationship between parental weight and income and children's weight at each point in time. Circumstances change over childhood, and parents' income and weight change over time in the sample. On average, families are in fact more likely to move up both the income and weight distribution over the study period. Tables A3 and A4 show this in the form of transition matrices for parents' income and weight class. A higher proportion of parents move up from the overweight class than down, and roughly $22 \%$ of those who were obese at 9 months were in the overweight weight range at 11. The group of parents in the normal weight range is also much larger than the obese group, and so the overall size of the overweight and obese groups increase (Table A2). Furthermore, as shown in Section 2, parents in the bottom quintile of the income distribution are far more likely to become obese or overweight during the sample period than parents in the highest quintile.

We can classify two broad channels through which the correlation between parents' weight and income and children's weight arises: (i) initial conditions (the parent's weight/income at birth/early childhood) and (ii) current conditions (the parent's contemporaneous weight/income if it has changed). Understanding to what extent the child's weight is linked to either of these channels is of crucial importance for the design of effective intervention and policy. However, by using contemporaneous income and weight groupings at every age to obtain the point-in-time relationships in Table 1, we mix these two effects. Initial conditions in income and weight are strongly correlated with current conditions. Using only current parental weight and income, we cannot attempt to understand whether the effects capture relationships at the current age or if they are due to "scarring" effects from initial conditions.

We therefore replace contemporaneous income and weight classifications in Equation 2 with their counterpart when children were aged 9 months. Doing this does not isolate the "effect" of initial conditions. Instead, it captures how the relative likelihood of overweight/obesity evolves in children based on these conditions. Changes in, for example, the $\gamma \mathrm{s}$ we estimate over time will result from both changes in the rates of overweight/obesity in children of parents who were obese at 9 months, and the changing role of conditions/unobservables. Using changes in parental weight and income classification we can attempt to separate to some extent the effect of current from initial conditions/unobservables, however. ${ }^{21}$ We therefore also include in our new version of Equation 2 dummy variables indicating whether, and how, parents' contemporaneous positions in the distribution of income and weight have changed. Appendix Tables B5, B6, and B7 report the marginal effects of these regressions for each of the outcomes in Table 1.

The estimates show that both initial and current parental weight significantly affect the likelihood of being overweight and obese across all ages. In all three tables, the estimated marginal effects of having an obese parent at 9 months are (often substantially) greater than the contemporaneous estimates from Table 1 at all ages between 3 and 14. Moreover, the estimated effects are again large in magnitude

\footnotetext{
${ }^{21}$ This is an imperfect estimate as we are not capturing all weight changes. For example, moving from a BMI of 40 to 31 would be indexed as no change. Using BMI changes rather than change of weight-class however comes with its own set of problems due to the non-linearity of BMI.
} 
relative to the conditional probability of each outcome. The parent changing to a heavier weight classification is associated with a large and significant increase in the likelihood a child is overweight or obese across all estimations. The reverse is not statistically significant for parents moving to a lighter weight classification at any age, suggesting that those who become obese are more likely to have overweight or obese children, but that weight declines in parents are not necessarily associated with differences in children's weight. Given that we know from Section 2 that low income parents are far more likely to become overweight or obese across the MCS, it is likely that these increases in weight are concentrated among low-income households. Despite this, the marginal effect of low-income remains large and significant and therefore the effect of low-income is not solely explained by an increased likelihood of children's parents becoming overweight and obese. Overall, these findings predict an even stronger relationship between initial and contemporaneous parental weight and child weight than Table 1 suggests.

The picture is less clear with the effect of moving up or down the income distribution. There are small negative (positive) point estimates of the effect of moving up (down) the income distribution at many ages. These findings are in line with intuition but often statistically insignificant. Overall they suggest that initial conditions in parental income are more important than changes in income in predicting your likelihood of overweight and obesity, perhaps because the constraints parents face when their child is 9 months old are predictive of those they face across the rest of childhood, even if their income increases. The point estimates of the effects of parental income quintiles at 9 months in Tables B5-B7 are broadly similar to their analogues in Table 1, although even more pronounced across the early ages.

Together, these results suggest that conditions at birth are important in determining overweight and obesity in children. Separating the estimates from Table 1 into some measure of contemporaneous and initial conditions accentuates the overall effect of parental income and weight on child weight. Although we do not attempt identify why we observe this relationship, the findings again show its magnitude. More so, they suggest that initial conditions in parental income and weight are predictive of the unobservable group characteristics - the many "constraints" we have discussed throughout - that will eventually result in children becoming overweight or obese.

\section{Healthy behaviour, Socioeconomic Status and Overweight}

So far we have found that children's weight is strongly correlated with their parents' weight and income across childhood, particularly over the early teenage years. This raises the question of why trajectories appear to diverge at this point in time. One answer might be that children grow a great deal during this period, and as their bodies undergo large changes the cumulative effects of lifestyle choices up until that point take effect. Another might be that it is at these ages that healthy behaviours and lifestyle choices themselves diverge across the income distribution and, as a consequence, so does the children's weight. In this section, we therefore address whether healthy behaviour similarly varies across the distribution of parents' income and weight and, if so, at what time differences emerge.

The MCS asks parents whether their child takes part in a range of healthy behaviour across all of 
its rounds. For example, it asks whether the child has regular meal times, how often they have fruit and vegetables, play sports or drink sweetened drinks. Unfortunately, however, the questions asked are not consistent over time. Only some appear consistently in multiple rounds, such as how often a child eats fruit and vegetables or plays sport with their parents. As a result, although we can look at the correlations between income and parents' weight and healthy behaviours at each age, it is difficult to make strict comparisons over time about their relative strength. Furthermore, it is important to emphasise once again that there is a degree of reverse causality between healthy behaviour and weight. In this section, we therefore again do not focus on estimating causal relationships between, for example, regular exercise and overweight. Rather, we analyse the extent to which patterns in the relationship between socioeconomic conditions, parental weight, and children's weight can be explained by any observed discrepancies in healthy behaviour across these groups.

All of the variables we use ask about frequencies with which children/parents engage in healthy behaviours. We transform these to binary variables to indicate presence of a healthy behaviour. In the example of fruit and vegetable consumption, the corresponding MCS question asks "how many portions of fruit or vegetables does the child have per day", with answers ranging from "None" to "Three or more". ${ }^{22}$ From this we create an indicator of whether or not the child has fruit or vegetables at least once a day. We then create a composite "index" of healthy behaviour, which indicates whether or not children engage in the majority of the individual healthy behaviours about which parents are asked. For example, at age 3 a child would be assigned a value of 1 if they eat fruit or vegetables once a day, have regular meal times, and play sport at least once a week. This is all three of the measures available at this age, and they cover both diet and exercise. At age 14, a child's lifestyle is marked as healthy if they engage in four of six healthy behaviours. At this age there are no exercise-related measures and so we rely solely on information on diet. With this index we aim to achieve a relatively consistent proportion of children being classified as healthy over time rather than a consistent definition of what is healthy, since the type and number of variables for healthy behaviour in our dataset change over time. ${ }^{23}$

This is not a perfect index of a healthy lifestyle. However, there are several advantages to working with such a composite index. To begin with, a healthy lifestyle is not a unique combination of factors. None of the identified individual behaviour indicators are strictly necessary and the composite can separate individuals by a minimum requirement for a healthy lifestyle. Furthermore, given the measures of healthy behaviour are discrete and highly correlated, the composite index avoids problems of collinearity in our regressions. Finally, our main question of interest in this section is how healthy behaviour varies across parental weight and income groups and how much of the variation in child's weight is explained by behaviour rather than membership of either of these groups. A composite index helps address these questions by attempting to define, albeit imperfectly, the overall environment as either healthy or not, and we will use it jointly with the individual measures available. A full list of

${ }^{22}$ This question actually differs slightly across ages. At age 3, it explicitly asks Does the child have fruit/veg. once a day?, but at age 14 the question is "How often [child] eats at least 2 portions of fruit?" with "every day" being a possible response. We define this answer as the measure of this type of health behaviour.

${ }^{23} \mathrm{~A}$ secondary concern in constructing the index was that the index was healthy relative to the average child in the survey. Although not an explicit target, the index we create classifies between 30\%-50\% of our sample as healthy across all ages. The qualitative results of this section remain unchanged using various different definitions for the composite measure of healthy behaviour, or the underlying measures from which it is constructed. 
the original variables, how we transform them and how they are then used to create our indicator of a healthy lifestyle is in Appendix A.2.

\subsection{Income, Parental Weight and Healthy Behaviour}

Table 2 shows the marginal effects of parental overweight and income from the following logit regressions using as an outcome our healthy behaviour index in each round:

$$
\operatorname{Pr}\left[I_{i t}=1 \mid \mathbf{\Omega}\right]=F\left(\delta_{t}+\boldsymbol{\gamma}_{t} \mathbf{Y}_{i t}+\boldsymbol{\rho}_{t} \mathbf{M P} \mathbf{W}_{i t}+\alpha_{t} O W O B_{i t}+\mathbf{x}_{i t}^{\prime} \boldsymbol{\beta}_{t}+\varepsilon_{i t}\right),
$$

where $\mathbf{\Omega}=\left(\mathbf{Y}_{i t}, \mathbf{M P W}_{i t}, O W O B_{i t}, \mathbf{x}_{i t}\right), I_{i t}$ is the indicator of whether a child engages in healthy behaviour defined above, and $F(), \mathbf{Y}_{\mathbf{i t}}, \mathbf{M P W _ { i t }}$ and $\mathbf{x}_{\mathbf{i t}}$ are as in Equation 2. Here, we also include an indicator of whether the child is overweight or obese at the relevant point in time, $O W O B_{i t}$.

The results show that there is a negative association between parental weight and income and the likelihood a child engages in healthy behaviour. For both, this association is statistically different from zero from age 5 . Whether the child is overweight or obese only shows a negative association from age 7 onward. Appendix Tables B9-B13 also show regressions using each individual healthy behaviour at each age as an outcome of Equation 3. These tables show that for the individual healthy behaviours the picture is much less clear. Although at every age there is a negative relationship between some healthy behaviour and parental obesity, across ages they are not consistent. For example, at age 5 having an obese parent is linked with a lower probability a child has regular meals, plays physically active games or sport, or plays sport with their parent (B10). It does not have an effect on consumption of fresh fruit and veg here, but does at age 7. The marginal effect of parents' weight is then negative but statistically indistinct from zero in determining whether a child has breakfast every day, or two of three exercise-related variables at age 11 (B12). It is unlikely that these components are affected so differently across ages. More plausibly, the issues with these estimates discussed before manifest themselves to varying extents across the separate samples.

The negative relationship between income and healthy behaviour is statistically significant at all ages except age 3 in Table 2. There is a negative marginal effect of belonging to any quintile relative to the highest, and these effects are consistently higher for the lowest quintiles across ages. Although there is a drop in the effect between the ages of 5 and 7, the marginal effects of being in each income quintile are largest at age 11 and 14. Looking at Tables B9-B13 we find that the effect of income is broad-based across types of behaviour and ages. Although again its relative effect on different individual behaviours is not consistent across the samples, in the majority of cases case we find large and significant negative estimates for the marginal effect of the lower income quintiles on healthy behaviours.

To help quantify the differences in behaviour across levels of income and parents' weight, Figures 4(a) and 4(b) show the predicted conditional probability that parents in the top versus the bottom income quintile and who are and are not obese meet our index of healthy behaviour respectively. These probabilities are computed from our estimates of Equation 3. The figure shows that the gradient in this measure of healthy behaviour is much larger across income quintiles and that it widens over time - by age 14 , a child in the highest income quintile is 21 percentage points more likely to engage in 
Table 2: Determinants of healthy behaviour index across ages

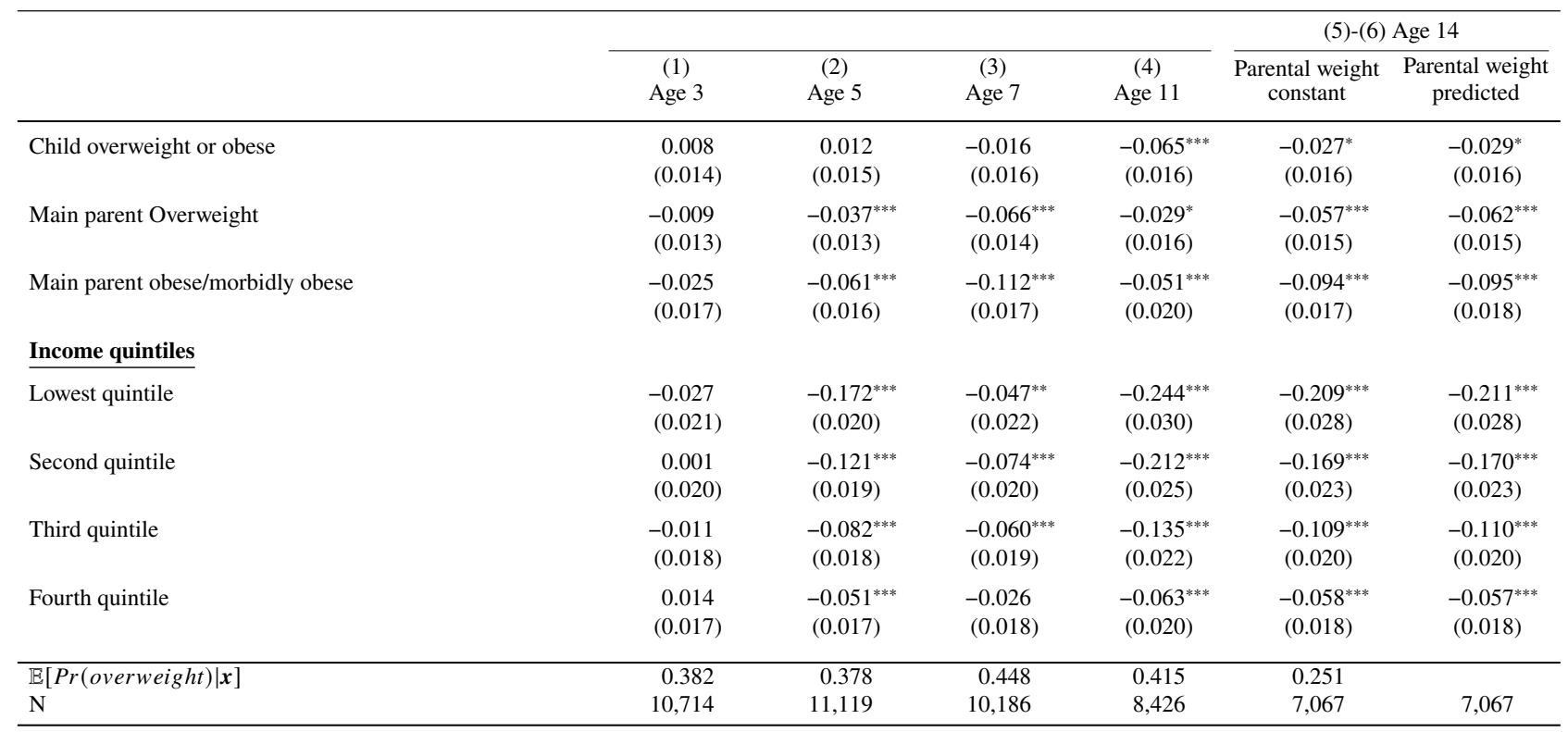

Note: $* * *$ and $* * *$ denote statistical significance it $10 \%, 5 \%$ and $1 \%$ respectively. The outcome in each column is whether a child has a healthy lifestyle, defined as described in Appendix A.2. The effects reported are marginal effects obtained after estimating Equation 3 fixing the independent variables at their sample mean. The MCS data does not contain parents' BMI at age 14, so columns 5 and 6 use BMI from age 11 or as predicted to define obesity. All observations are adjusted for the probability of attrition and being sampled, see (Hansen et al., 2014). The omitted categories are income: highest quintile; parents' education: no qualifications; ethnicity: white. $\mathbb{E}[\operatorname{Pr}($ Healthybehaviour $) \mid \boldsymbol{x}]$ represents the estimated conditional expectation a child exihibits healthy beaviour. The main parent is the mother for over $99 \%$ of children at 9 months. Ns differ across columns because of missing data.

healthy behaviour than those in the lowest. In line with the results of this section so far, the differences are smaller across parents' weight at all ages, and at age 14 children of parents whose BMI is in the obese range are only 9.5 percentage points less likely to engage in this behaviour. Note that the exact definition of the healthy behaviour index changes over time and that these trends are consistent with different definitions of the index.

Overall, the results in Tables B9-B13 suggest that there are differences in the healthy behaviour of parents who are obese and/or who are in the lower end of the income distribution. These differences are present across all of childhood and in both nutritional and exercise based healthy behaviour. Given that we capture these relationships in our index measure and individual measures of healthy behaviour, we interpret these findings as evidence that healthy behaviour is consistently less prevalent in lower income quintiles and families with overweight and obese parents. In the next section, we explore how much of the correlations identified between children's weight and their parents' weight and income can be explained by variation in healthy behaviour across these groups. 
Figure 4: Predicted conditional probability of healthy behaviour across ages, by income quintile and parents' wieght

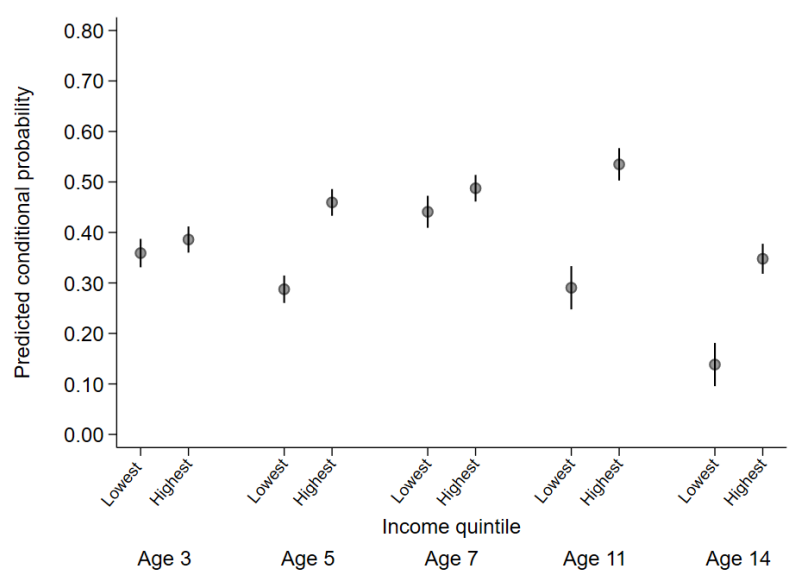

(a) Income quintile

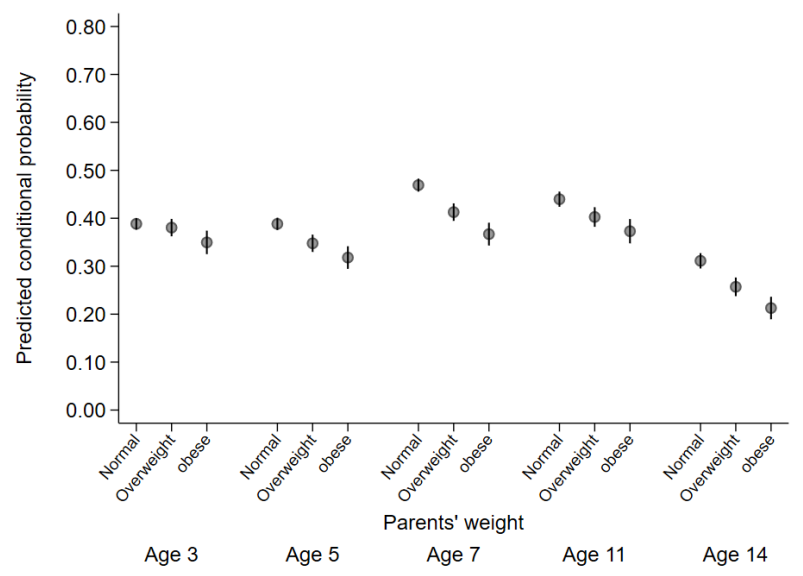

(b) Parents' weight

Note: Each panel shows conditional probabilities predicted by estimating a version of Equation 3 at age 3 and 14 . The outcome, healthy behaviour, is defined in Appendix A.2. Each panel shows the predicted conditional probability of this outcome atage 3 and 14 under the values of either income (panel (a)) or parents' weight (panel (b)) indicated along their $\mathrm{x}$ axes. Dots represent estimated conditional probabilities and vertical lines their $95 \%$ confidence interval. The regressions from which they were calculated controlled for children's weight, gender, birth weight, weight gain between birth and 9 months, whether they have a long-term illness and the number of health conditions reported, ethnicity, the number of siblings in the household, and the parent's level of education and whether they have a long-term illness. All observations are adjusted for the probability of attrition and being sampled, see (Hansen et al., 2014). Appendix Tables B9-B13 show estimates of how all of these are associated with individual healthy behaviours at each age. All other variables are fixed at their mean.

\subsection{Healthy Behaviour and Socioeconomic Gradients in Overweight}

Parental income and weight are correlated with healthy behaviour across the majority of childhood. To address the question of whether healthy behaviour is associated with lower incidence of overweight and obesity in children, and whether it can explain any of the effect of income and parental weight on children's weight, we return to the specification of Section 3, augmenting it with our healthy behaviour index. That is, we augment Equation 2 with $I_{i t}$ in the following way:

$$
\operatorname{Pr}\left[O W O B_{i t}=1 \mid \mathbf{\Omega}\right]=F\left(\delta_{t}+\theta_{t} I_{i t}+\gamma_{t} \mathbf{Y}_{i t}+\boldsymbol{\rho}_{t} \mathbf{M P W}_{i t}+\mathbf{x}_{\mathbf{i t}}{ }^{\prime} \boldsymbol{\beta}_{t}+\varepsilon_{i t}\right),
$$

where now $\mathbf{\Omega}=\left(\mathbf{Y}_{i t}, \mathbf{M P W} \mathbf{W}_{i t}, I_{i t}, \mathbf{x}_{i t}\right)$ but all other variables are as in Equation 2. Again, we estimate this equation separately across all ages and assess the extent to which healthy behaviour impacts on overweight and obesity. In Section 3 we discussed that we did not seek to account for unobserved behavioural factors that might influence the relationship between parental income and weight and children's weight. Including $I_{i t}$ allows us to explicitly capture some of these factors and analyse to what extent these relationships are a result of differences in healthy behaviour. Similarly to Table 1, Table 3 shows the marginal effects of $\mathbf{M P W _ { i t }}$ and $\mathbf{Y}_{i t}$ on overweight, obesity and either in children across all ages, but with the inclusion of $I_{i t}$.

Healthy behaviour as we measure it in our index only has a statistically significant relationship 
with children's weight at ages 11 and 14. This effect is present at 11 in both the likelihood a child is overweight (panel A) and obese (panel B) and at 14 only it is only significant for the likelihood a child is either (panel C). Appendix Tables B17(a)-B19(b) show the marginal effects of MPW $\mathbf{W}_{i t}$ and $\mathbf{Y}_{i t}$ on the same outcomes in including all individual health behaviours that make up the composite index $I_{i t}$ at each age.

Focusing initially on the incidence of overweight or obesity, Table B19(a) shows that the relationship we find in Table 3 at age 11 and 14 is a result of the negative correlation of overweight with playing physically active games or sport once a week, having breakfast every day, and drinking artificially sweetened drinks less than once a day. The lack of sports variables at age 14 could explain why we find a stronger estimate at age 11 . We also find significant positive estimates for the effect of consuming less fast food and sweetened drinks. This shows the effect of reverse causality between weight and dietary behaviour - parents introducing restrictions on their children's diet - and should not be read as evidence that these behaviours reduce the likelihood of obesity. Finally, at age 3, 5, and 7, no individual behaviour is statistically significant, not even consistently the indicators of playing active games and sport which are significant at later ages. This could hint towards the behaviour observed in our dataset only having sizable effects later in childhood. It could also be that the divergence we observe in healthy behaviour across income quintiles in Figure 4(a) plays a role in the widening of rates of overweight and obesity across the income distribution. However, because our index is not entirely consistent over time and because we do not interpret these marginal effects as causal, we can only take this as suggestive evidence. Without a better understanding of both the home environment and the biases present in these regressions, these results are not sufficient evidence to arrive at any strong conclusions.

Comparing the effects of income quintiles and parents' obesity in Table 3 with those in 1 we can grasp how much of their effect is explained by differences in the healthy behaviour we measure. Focusing on the effect of parental obesity on the likelihood of children's overweight we find that although there is very slight attenuation of the effect, the direction and significance of our estimated effects with and without the inclusion of healthy behaviour are almost identical. The size of the effect is virtually always within one standard deviation of the previous estimates. Finally, these conclusions are the same if we use the full set of behaviours (Appendix Table B14 to B16) or the composite index (Table 3).

Looking at the estimates for the impact of being in different income quintiles with and without accounting for the observed behavioural tendencies the conclusions are very similar to the impact of parental weight. Overall, here, estimates are again often slightly attenuated when accounting for behaviour, but none of our estimates change significance, or even magnitude by more than one standard deviation. Although we find slightly more attenuation for the estimated effects when accounting for all individual behaviours separately, these conclusions once again are robust to this change. ${ }^{24}$

Overall, although the effects of income and parents' weight are slightly attenuated when healthy behaviours are considered as determinants of overweight and obesity, the difference they make is marginal. This suggests that differences in the healthy behaviours on which we have measures do not explain differences in the likelihood of overweight and obesity in children across the income

\footnotetext{
${ }^{24}$ Again, our qualitative results are robust to various definitions of both the composite index and its underlying measures.
} 
Table 3: Healthy behaviours and overweight and obesity in children across ages

\begin{tabular}{|c|c|c|c|c|c|c|}
\hline & & & & & \multicolumn{2}{|c|}{ (5)-(6) Age 14} \\
\hline & $\begin{array}{c}\text { (1) } \\
\text { Age } 3\end{array}$ & $\begin{array}{c}\text { (2) } \\
\text { Age } 5\end{array}$ & $\begin{array}{c}\text { (3) } \\
\text { Age } 7\end{array}$ & $\begin{array}{c}(4) \\
\text { Age } 11\end{array}$ & $\begin{array}{l}M P B M I \\
\text { constant }\end{array}$ & $\begin{array}{c}\text { MPBMI } \\
\text { predicted }\end{array}$ \\
\hline \multicolumn{7}{|l|}{ Panel A: Probability of overweight } \\
\hline Healthy lifestyle & $\begin{array}{c}-0.003 \\
(0.008)\end{array}$ & $\begin{array}{c}0.006 \\
(0.008)\end{array}$ & $\begin{array}{l}-0.008 \\
(0.008)\end{array}$ & $\begin{array}{c}-0.028^{* *} \\
(0.011)\end{array}$ & $\begin{array}{l}-0.018 \\
(0.012)\end{array}$ & $\begin{array}{c}-0.019 \\
(0.012)\end{array}$ \\
\hline Main parent overweight & $\begin{array}{l}0.022^{* *} \\
(0.010)\end{array}$ & $\begin{array}{l}0.058^{* * *} \\
(0.009)\end{array}$ & $\begin{array}{l}0.061^{* * *} \\
(0.010)\end{array}$ & $\begin{array}{l}0.099^{* * *} \\
(0.013)\end{array}$ & $\begin{array}{l}0.102^{* * *} \\
(0.014)\end{array}$ & $\begin{array}{l}0.072^{* * *} \\
(0.012)\end{array}$ \\
\hline Main parent obese/morbidly obese & $\begin{array}{l}0.061^{* * *} \\
(0.014)\end{array}$ & $\begin{array}{l}0.124^{* * *} \\
(0.014)\end{array}$ & $\begin{array}{l}0.093^{* * *} \\
(0.013)\end{array}$ & $\begin{array}{l}0.197^{* * *} \\
(0.017)\end{array}$ & $\begin{array}{l}0.168^{* * *} \\
(0.018)\end{array}$ & $\begin{array}{l}0.169^{* * *} \\
(0.017)\end{array}$ \\
\hline \multicolumn{7}{|l|}{ Income quintiles } \\
\hline Lowest quintile & $\begin{array}{l}0.037^{* *} \\
(0.016)\end{array}$ & $\begin{array}{r}0.024^{*} \\
(0.014)\end{array}$ & $\begin{array}{c}0.010 \\
(0.015)\end{array}$ & $\begin{array}{c}0.024 \\
(0.025)\end{array}$ & $\begin{array}{l}0.112^{* * *} \\
(0.033)\end{array}$ & $\begin{array}{l}0.116^{* * *} \\
(0.033)\end{array}$ \\
\hline Second quintile & $\begin{array}{l}0.034^{* *} \\
(0.014)\end{array}$ & $\begin{array}{c}0.009 \\
(0.013)\end{array}$ & $\begin{array}{c}0.017 \\
(0.014)\end{array}$ & $\begin{array}{l}0.049^{* *} \\
(0.021)\end{array}$ & $\begin{array}{l}0.051^{* * *} \\
(0.021)\end{array}$ & $\begin{array}{l}0.050^{* *} \\
(0.021)\end{array}$ \\
\hline Third quintile & $\begin{array}{l}0.029^{* *} \\
(0.013)\end{array}$ & $\begin{array}{c}-0.004 \\
(0.011)\end{array}$ & $\begin{array}{c}0.012 \\
(0.013)\end{array}$ & $\begin{array}{l}0.053^{* * *} \\
(0.018)\end{array}$ & $\begin{array}{c}0.038^{* *} \\
(0.016)\end{array}$ & $\begin{array}{l}0.039^{* *} \\
(0.016)\end{array}$ \\
\hline Fourth quintile & $\begin{array}{r}0.023^{*} \\
(0.012)\end{array}$ & $\begin{array}{r}0.022^{*} \\
(0.011)\end{array}$ & $\begin{array}{c}0.002 \\
(0.011)\end{array}$ & $\begin{array}{c}0.017 \\
(0.015)\end{array}$ & $\begin{array}{c}0.011 \\
(0.013)\end{array}$ & $\begin{array}{c}0.010 \\
(0.013)\end{array}$ \\
\hline $\begin{array}{l}\mathbb{E}[\operatorname{Pr}(\text { overweight }) \mid x] \\
\mathrm{N}\end{array}$ & $\begin{array}{r}0.161 \\
10,143\end{array}$ & $\begin{array}{r}0.133 \\
10,485\end{array}$ & $\begin{array}{l}0.124 \\
9,405\end{array}$ & $\begin{array}{l}0.198 \\
7,887\end{array}$ & $\begin{array}{l}0.155 \\
6,674\end{array}$ & $\begin{array}{l}0.156 \\
6,674\end{array}$ \\
\hline \multicolumn{7}{|l|}{ Panel B: Probability of obesity } \\
\hline Healthy lifestyle & $\begin{array}{c}0.009^{* *} \\
(0.004)\end{array}$ & $\begin{array}{l}-0.001 \\
(0.004)\end{array}$ & $\begin{array}{c}-0.001 \\
(0.004)\end{array}$ & $\begin{array}{l}-0.022^{* * *} \\
(0.005)\end{array}$ & $\begin{array}{l}-0.007 \\
(0.006)\end{array}$ & $\begin{array}{l}-0.007 \\
(0.006)\end{array}$ \\
\hline Main parent overweight & $\begin{array}{l}0.018^{* * *} \\
(0.005)\end{array}$ & $\begin{array}{l}0.023^{* * *} \\
(0.005)\end{array}$ & $\begin{array}{l}0.031^{* * *} \\
(0.005)\end{array}$ & $\begin{array}{l}0.031^{* * *} \\
(0.006)\end{array}$ & $\begin{array}{l}0.022^{* * *} \\
(0.006)\end{array}$ & $\begin{array}{l}0.021^{* * *} \\
(0.005)\end{array}$ \\
\hline Main parent obese/morbidly obese & $\begin{array}{l}0.041^{* * * *} \\
(0.008)\end{array}$ & $\begin{array}{l}0.057^{* * *} \\
(0.008)\end{array}$ & $\begin{array}{c}0.079^{* * *} \\
(0.009)\end{array}$ & $\begin{array}{l}0.071^{* * *} \\
(0.009)\end{array}$ & $\begin{array}{l}0.092^{* * *} \\
(0.011)\end{array}$ & $\begin{array}{l}0.086^{* * *} \\
(0.010)\end{array}$ \\
\hline \multicolumn{7}{|l|}{ Income quintiles } \\
\hline Lowest quintile & $\begin{array}{c}0.017^{* *} \\
(0.008)\end{array}$ & $\begin{array}{c}0.014^{*} \\
(0.008)\end{array}$ & $\begin{array}{c}0.013^{*} \\
(0.008)\end{array}$ & $\begin{array}{c}0.026^{* *} \\
(0.011)\end{array}$ & $\begin{array}{l}0.063^{* * *} \\
(0.018)\end{array}$ & $\begin{array}{l}0.063^{* * *} \\
(0.017)\end{array}$ \\
\hline Second quintile & $\begin{array}{c}0.011 \\
(0.006)\end{array}$ & $\begin{array}{c}0.010 \\
(0.007)\end{array}$ & $\begin{array}{c}0.010 \\
(0.007)\end{array}$ & $\begin{array}{l}0.028^{* * *} \\
(0.009)\end{array}$ & $\begin{array}{l}0.024^{* * *} \\
(0.009)\end{array}$ & $\begin{array}{l}0.024^{* * *} \\
(0.009)\end{array}$ \\
\hline Third quintile & $\begin{array}{c}0.003 \\
(0.006)\end{array}$ & $\begin{array}{c}0.005 \\
(0.006)\end{array}$ & $\begin{array}{c}0.006 \\
(0.006)\end{array}$ & $\begin{array}{c}0.015^{*} \\
(0.008)\end{array}$ & $\begin{array}{c}0.014^{* *} \\
(0.007)\end{array}$ & $\begin{array}{l}0.015^{* *} \\
(0.007)\end{array}$ \\
\hline Fourth quintile & $\begin{array}{c}0.012^{*} \\
(0.006)\end{array}$ & $\begin{array}{c}0.005 \\
(0.006)\end{array}$ & $\begin{array}{c}0.005 \\
(0.006)\end{array}$ & $\begin{array}{c}0.006 \\
(0.006)\end{array}$ & $\begin{array}{c}0.008 \\
(0.006)\end{array}$ & $\begin{array}{c}0.007 \\
(0.006)\end{array}$ \\
\hline $\mathbb{E}[\operatorname{Pr}($ obese $) \mid x]$ & $\begin{array}{r}0.038 \\
10714\end{array}$ & $\begin{array}{r}0.039 \\
1119\end{array}$ & $\begin{array}{r}0.042 \\
10186\end{array}$ & $\begin{array}{l}0.042 \\
8.426\end{array}$ & $\begin{array}{l}0.039 \\
7.067\end{array}$ & $\begin{array}{l}0.038 \\
7.067\end{array}$ \\
\hline \multicolumn{7}{|c|}{ Panel B: Probability of overweight or obesity } \\
\hline Healthy lifestyle & $\begin{array}{c}0.005 \\
(0.009)\end{array}$ & $\begin{array}{c}0.005 \\
(0.009)\end{array}$ & $\begin{array}{c}-0.009 \\
(0.009)\end{array}$ & $\begin{array}{l}-0.049^{* * *} \\
(0.012)\end{array}$ & $\begin{array}{c}-0.025^{*} \\
(0.013)\end{array}$ & $\begin{array}{c}-0.026^{*} \\
(0.013)\end{array}$ \\
\hline Main parent overweight & $\begin{array}{c}0.036^{* * * *} \\
(0.011)\end{array}$ & $\begin{array}{l}0.077^{* * *} \\
(0.010)\end{array}$ & $\begin{array}{l}0.085^{* * *} \\
(0.010)\end{array}$ & $\begin{array}{l}0.122^{* * *} \\
(0.013)\end{array}$ & $\begin{array}{l}0.119^{* * *} \\
(0.014)\end{array}$ & $\begin{array}{l}0.090^{* * * *} \\
(0.013)\end{array}$ \\
\hline Main parent obese/morbidly obese & $\begin{array}{l}0.094^{* * *} \\
(0.015)\end{array}$ & $\begin{array}{l}0.169^{* * *} \\
(0.015)\end{array}$ & $\begin{array}{l}0.159^{* * *} \\
(0.014)\end{array}$ & $\begin{array}{l}0.249^{* * *} \\
(0.017)\end{array}$ & $\begin{array}{l}0.241^{* * *} \\
(0.018)\end{array}$ & $\begin{array}{c}0.238^{* * *} \\
(0.018)\end{array}$ \\
\hline \multicolumn{7}{|l|}{ Income quintiles } \\
\hline Lowest quintile & $\begin{array}{c}0.054^{* * *} \\
(0.017)\end{array}$ & $\begin{array}{c}0.037^{* *} \\
(0.016)\end{array}$ & $\begin{array}{c}0.025 \\
(0.016)\end{array}$ & $\begin{array}{c}0.051^{* *} \\
(0.026)\end{array}$ & $\begin{array}{l}0.165^{* * *} \\
(0.033)\end{array}$ & $\begin{array}{l}0.169^{* * *} \\
(0.034)\end{array}$ \\
\hline Second quintile & $\begin{array}{l}0.042^{* * *} \\
(0.015)\end{array}$ & $\begin{array}{c}0.017 \\
(0.014)\end{array}$ & $\begin{array}{c}0.023 \\
(0.015)\end{array}$ & $\begin{array}{l}0.074^{* * *} \\
(0.022)\end{array}$ & $\begin{array}{l}0.073^{* * *} \\
(0.022)\end{array}$ & $\begin{array}{c}0.073^{* * *} \\
(0.022)\end{array}$ \\
\hline Third quintile & $\begin{array}{c}0.030^{* *} \\
(0.014)\end{array}$ & $\begin{array}{c}0.001 \\
(0.013)\end{array}$ & $\begin{array}{c}0.018 \\
(0.014)\end{array}$ & $\begin{array}{l}0.066^{* * *} \\
(0.019)\end{array}$ & $\begin{array}{l}0.052^{* * *} \\
(0.017)\end{array}$ & $\begin{array}{l}0.053^{* * *} \\
(0.017)\end{array}$ \\
\hline Fourth quintile & $\begin{array}{c}0.031^{* *} \\
(0.013)\end{array}$ & $\begin{array}{l}0.026^{* *} \\
(0.013)\end{array}$ & $\begin{array}{c}0.006 \\
(0.013)\end{array}$ & $\begin{array}{c}0.023 \\
(0.016)\end{array}$ & $\begin{array}{c}0.018 \\
(0.014)\end{array}$ & $\begin{array}{c}0.017 \\
(0.014)\end{array}$ \\
\hline $\mathbb{E}[\operatorname{Pr}($ overweight $\cup$ obese $) \mid x]$ & 0.199 & 0.175 & 0.165 & 0.241 & 0.196 & 0.197 \\
\hline $\mathrm{N}$ & 10,714 & 11,119 & 10,186 & 8,426 & 7,067 & 7,067 \\
\hline
\end{tabular}

Note: $* * *$ and $* * *$ denote statistical significance it $10 \%, 5 \%$ and $1 \%$ respectively. The outcome in each column is indicated by Panels A-C, and are defined using the the IOTF cutoffs (Table A1). The effects reported are marginal effects obtained after estimating Equation 4 fixing the independent variables at their sample mean. The MCS data do not contain parents' BMI at age 14 , so columns 5 and 6 use BMI from age 11 or as predicted to define obesity. The omitted income category is the highest quintile. AThe regressions from which they were calculated controlled for children's gender, birth weight, weight gain between birth and 9 months, whether they have a long-term illness and the number of health conditions reported, ethnicity, the number of siblings in the household, and the parent's level of education and whether they have a long-term illness. Appendix Tables B2-B4 show the full results. $\mathbb{E}[\operatorname{Pr}($ outcome $) \mid \boldsymbol{x}]$ represents the estimated conditional expectation of each outcome. The main parent is the mother for over $99 \%$ of children at 9 months. Ns differ in Panel A because these regressions exclude obse children. Ns differ across columns because of missing data. 
distribution or whether their parent is obese themselves. Taken together with the fact that, even with our composite index, we observe differences in healthy behaviour over time across groups (Table B8), these results suggest that the variation in healthy behaviour we measure is indicative that there are systematic differences in the wider environment children face across childhood. Measuring these wider differences is key to understanding the mechanisms that give way to the relationship between income and parent's weight we observed in Section 3.

\section{Conclusion}

In this paper we studied the evolution of socioeconomic gradients in overweight and obesity amongst a cohort of UK children born at the turn of the millennium. We focus on the extent to which early conditions predict whether children are overweight or obese at 14, and how the relationship between socioeconomic status and children's weight changes between the ages of 3 and 14 . We further analyse how accounting for healthy behaviour affects these outcomes and how behaviour is determined by parents' weight and family income.

We find that conditions at 9 months largely predict whether children are overweight or obese at age 14. Children at both the top and bottom of the income distribution are more than four times as likely to be obese if they have an obese parent at 9 months of age than if they do not. Moreover, our results show the children from low-income families are also consistently more likely to be obese, whether their parent has normal, overweight or obese BMI: by age 14, children born into the poorest $20 \%$ of families as opposed to the richest $20 \%$ are twice as likely to be obese. After controlling for a rich set of environmental and circumstantial factors, we find that the relationship between children's weight and the income and weight of their parents holds up at all ages for which we have data and in fact strengthens as children age.

In our data, as children age their parents' weight and income changes. We show that both initial and contemporaneous conditions determine weight at any given age. We find that children whose parent's become obese during their childhood have an increased likelihood of becoming overweight or obese themselves, however the effect is smaller than the estimated effect of parental weight at birth. Moreover, movements up or down the income distribution have little effect and it is largely only initial parental income that correlates with children's weight. This suggests that children's socioeconomic background as early as 9 months is predictive of the conditions that result in the onset of overweight or obesity at some point in childhood. We further analyse the determinants of healthy behaviour across ages, and find differences in engagement across both parents' weight and income. Children in the bottom $20 \%$ of the income distribution are far less likely than those in the top $20 \%$ to engage in healthy behaviour across all ages. However, despite observing a positive relationship between observed healthy behaviour and parental weight and income, accounting for it in our estimations has very little effect in the sign, significance, and size of the relationships we find between parental income and weight and children's weight.

Our findings highlight the extent to which childhood obesity - and obesity more generally - is an economic problem. Parental income and weight do not cause children to be obese. Obesity is caused by 
consuming more calories than are burnt for a sustained period of time. This relationship is individually determined in a complex system of social, environmental, biological, economic, psychological, and behavioural factors. Our results show that parental income and weight are strongly correlated to these unobserved factors. Observing the difference in conditions between socioeconomic groups, even without describing exactly what these conditions are, highlights the importance of economic conditions in determining the onset of obesity. It shows that different groups in our society play a separating equilibrium when it comes to healthy behaviour and that this difference is to the detriment of the already disadvantaged. As a result, relatively small differences in children's weight across socioeconomic groups appear as early as age 3 , and widen significantly over time to generate inequality in obesity by the teenage years. Both of these facts suggest policies for reducing these inequalities should aim to mitigate the detrimental effects of socioeconomic conditions on the healthy environment early in childhood. Doing so might act to prevent the onset of obesity, and reduce the need for remedial policies in later life.

The economics discipline has made progress toward understanding how inequality in important components of human capital emerge as a result of early social and economic conditions. The same tools that have generated this progress can, and should, be used to shed light on what is driving inequality in obesity and its transmission across generations. 


\section{References}

Almond, D., J. Currie, and V. Duque. 2018. "Childhood circumstances and adult outcomes: Act ii." Journal of Economic Literature, 56(4): 1360-1446.

Attanasio, O., T. Boneva, and C. Rauh. 2019. "Parental beliefs about returns to different types of investments in school children.”Technical report, National Bureau of Economic Research.

Baum, C. L., and W. F. Ford. 2004. "The wage effects of obesity: a longitudinal study." Health economics, 13(9): 885-899.

Biroli, P., T. Boneva, A. Raja, and C. Rauh. 2020. "Parental beliefs about returns to child health investments." Journal of Econometrics.

Brodersen, N. H., A. Steptoe, D. R. Boniface, and J. Wardle. 2007. "Trends in physical activity and sedentary behaviour in adolescence: ethnic and socioeconomic differences." British journal of sports medicine, 41(3): 140-144.

Carneiro, P., C. Meghir, and M. Parey. 2013. "Maternal education, home environments, and the development of children and adolescents." Journal of the European Economic Association, 11(suppl_1): 123-160.

Carniero, P., S. Cattan, L. Dearden, L. van der Erve, S. Krutikova, and L. Macmillan."The long shadow of deprivation: Differences in opportunities across england.’Technical report.

Cawley, J. 2004. “The impact of obesity on wages." Journal of Human resources, 39(2): 451-474.

Cawley, J. 2010. “The economics of childhood obesity.” Health affairs, 29(3): 364-371.

Cawley, J. 2011. The Oxford handbook of the social science of obesity. Oxford University Press.

Cawley, J., and C. K. Spiess. 2008. “Obesity and skill attainment in early childhood.” Economics \& Human Biology, 6(3): 388-397.

Cole, T. J., M. C. Bellizzi, K. M. Flegal, and W. H. Dietz. 2000. "Establishing a standard definition for child overweight and obesity worldwide: international survey." Bmj, 320(7244): , p. 1240.

Cole, T. J., J. V. Freeman, and M. A. Preece. 1995. "Body mass index reference curves for the uk, 1990.." Archives of disease in childhood, 73(1): 25-29.

Costa-Font, J., and J. Gil. 2013. "Intergenerational and socioeconomic gradients of child obesity." Social science \& medicine, 93 29-37.

Crossman, A., D. A. Sullivan, and M. Benin. 2006. "The family environment and american adolescents' risk of obesity as young adults." Social science \& medicine, 63(9): 2255-2267.

Cunha, F., I. Elo, and J. Culhane. 2013. "Eliciting maternal expectations about the technology of cognitive skill formation.’Technical report, National Bureau of Economic Research. 
Cunha, F., and J. Heckman. 2007. "The technology of skill formation.” American Economic Review, 97(2): 31-47.

Cunha, F., and J. J. Heckman. 2008. "Formulating, identifying and estimating the technology of cognitive and noncognitive skill formation." Journal of human resources, 43(4): 738-782.

Cunha, F., J. J. Heckman, and S. M. Schennach. 2010. "Estimating the technology of cognitive and noncognitive skill formation.” Econometrica, 78(3): 883-931.

Currie, J. 2009. "Healthy, wealthy, and wise: Socioeconomic status, poor health in childhood, and human capital development." Journal of economic literature, 47(1): 87-122.

Currie, J., and D. Almond. 2011. "Human capital development before age five." In Handbook of labor economics. 4 Elsevier, 1315-1486.

Currie, J., and R. Hyson. 1999. "Is the impact of health shocks cushioned by socioeconomic status? the case of low birthweight." American Economic Review, 89(2): 245-250.

Dixon, J. B. 2010. "The effect of obesity on health outcomes." Molecular and cellular endocrinology, 316(2): 104-108.

Downs, J. S., G. Loewenstein, and J. Wisdom. 2009. "Strategies for promoting healthier food choices." American Economic Review, 99(2): 159-64.

Ebbeling, C. B., D. B. Pawlak, and D. S. Ludwig. 2002. "Childhood obesity: public-health crisis, common sense cure." The lancet, 360(9331): 473-482.

Goisis, A., A. Sacker, and Y. Kelly. 2016. "Why are poorer children at higher risk of obesity and overweight? a uk cohort study." The European Journal of Public Health, 26(1): 7-13.

Griffiths, L., S. Hawkins, T. Cole, and C. Dezateux. 2010. "Risk factors for rapid weight gain in preschool children: findings from a uk-wide prospective study." International journal of obesity, 34(4): 624-632.

Gundersen, C., D. Mahatmya, S. Garasky, and B. Lohman. 2011. "Linking psychosocial stressors and childhood obesity." Obesity reviews, 12(5): e54-e63.

Hales, C. M., M. D. Carroll, C. D. Fryar, and C. L. Ogden. 2017. "Prevalence of obesity among adults and youth: United states, 2015-2016.”Technical report, National Centre for Health Statistics.

Han, E., E. C. Norton, and S. C. Stearns. 2009. "Weight and wages: fat versus lean paychecks." Health economics, 18(5): 535-548.

Hansen, K., J. Johnson, L. Calderwood, T. Mostafa, L. Platt, R. Rosenberg, and K. Smith. 2014. "Millennium cohort study: A guide to the datasets (eighth edition).”'Technical report, Centre for Longitudinal Studies. 
Heckman, J. J., and T. Kautz. 2012. "Hard evidence on soft skills." Labour economics, 19(4): 451-464.

Lighter, J., M. Phillips, S. Hochman, S. Sterling, D. Johnson, F. Francois, and A. Stachel. 2020. "Obesity in patients younger than 60 years is a risk factor for covid-19 hospital admission." Clinical Infectious Diseases.

Loewenstein, G., D. A. Asch, J. Y. Friedman, L. A. Melichar, and K. G. Volpp. 2012. "Can behavioural economics make us healthier?" Bmj, 344.

Ludwig, D. S., H. L. Rouse, and J. Currie. 2013. "Pregnancy weight gain and childhood body weight: a within-family comparison." PLoS medicine, 10(10): .

McElroy, S. L., R. Kotwal, S. Malhotra, E. B. Nelson, P. E. Keck Jr, and C. B. Nemeroff. 2004. "Are mood disorders and obesity related? a review for the mental health professional.." The Journal of Clinical Psychiatry.

Mokdad, A. H., E. S. Ford, B. A. Bowman, W. H. Dietz, F. Vinicor, V. S. Bales, and J. S. Marks. 2003. "Prevalence of obesity, diabetes, and obesity-related health risk factors, 2001." Jama, 289(1): 76-79.

Nader, P. R., M. O'Brien, R. Houts, R. Bradley, J. Belsky, R. Crosnoe, S. Friedman, Z. Mei, E. J. Susman et al. 2006. "Identifying risk for obesity in early childhood." Pediatrics, 118(3): e594-e601.

Nelson, M. C., D. Neumark-Stzainer, P. J. Hannan, J. R. Sirard, and M. Story. 2006. "Longitudinal and secular trends in physical activity and sedentary behavior during adolescence." Pediatrics, 118(6): e1627-e1634.

NHS Digital. 2019. “Statistics on obesity, physical activity and diet, england, 2019.”Technical report, Lifestyles Team, NHS Digital.

Ogden, C. L., M. D. Carroll, T. H. Fakhouri, C. M. Hales, C. D. Fryar, X. Li, and D. S. Freedman. 2018. "Prevalence of obesity among youths by household income and education level of head of household—united states 2011-2014." Morbidity and mortality weekly report, 67(6): , p. 186.

Peeters, A., J. J. Barendregt, F. Willekens, J. P. Mackenbach, A. A. Mamun, and L. Bonneux. 2003. "Obesity in adulthood and its consequences for life expectancy: a life-table analysis." Annals of internal medicine, 138(1): 24-32.

Public Health England. 2020. “Excess weight and covid-19, insights from new evidence.’Technical report, Public Health England [Accessed 2 September 2020].

Reilly, J. J., J. Armstrong, A. R. Dorosty, P. M. Emmett, A. Ness, I. Rogers, C. Steer, and A. Sherriff. 2005. "Early life risk factors for obesity in childhood: cohort study." Bmj, 330(7504): , p. 1357. 
Reilly, J. J., E. Methven, Z. C. McDowell, B. Hacking, D. Alexander, L. Stewart, and C. J. Kelnar. 2003. "Health consequences of obesity." Archives of disease in childhood, 88(9): 748-752.

Sahoo, K., B. Sahoo, A. K. Choudhury, N. Y.Sofi, R. Kumar, and A. S. Bhadoria. 2015. "Childhood obesity: causes and consequences." Journal of family medicine and primary care, 4(2): , p. 187.

Scott, K. M., M. A. McGee, J. E. Wells, and M. A. O. Browne. 2008. "Obesity and mental disorders in the adult general population.” Journal of psychosomatic research, 64(1): 97-105.

WHO. 2018. International Classification of Diseases $\left(11^{\text {th }}\right.$ revision). World Health Organization. 


\section{A Additional Descriptive Results}

\section{A.1 Additional descriptive tables and figures}

Table A1: Thresholds for overweight and obesity in children in the MCS, by age and gender

\begin{tabular}{lcccc}
\hline & \multicolumn{2}{c}{ Boys } & \multicolumn{2}{c}{ Girls } \\
& Overweight & Obese & Overweight & Obese \\
\hline 3 years & 17.89 & 19.57 & 17.56 & 19.36 \\
5 years & 17.42 & 19.30 & 17.14 & 19.17 \\
7 years & 17.92 & 20.63 & 17.75 & 20.51 \\
11 years & 20.55 & 25.10 & 20.74 & 25.42 \\
14 years & 23.29 & 28.30 & 23.94 & 29.11 \\
\hline
\end{tabular}

Source: International Obesity Task Force (IOTF) Body Mass Index (BMI) cutoffs for overweight and obesity, Cole et al. (2000). 
Table A2: Characteristics of the full MCS sample across waves

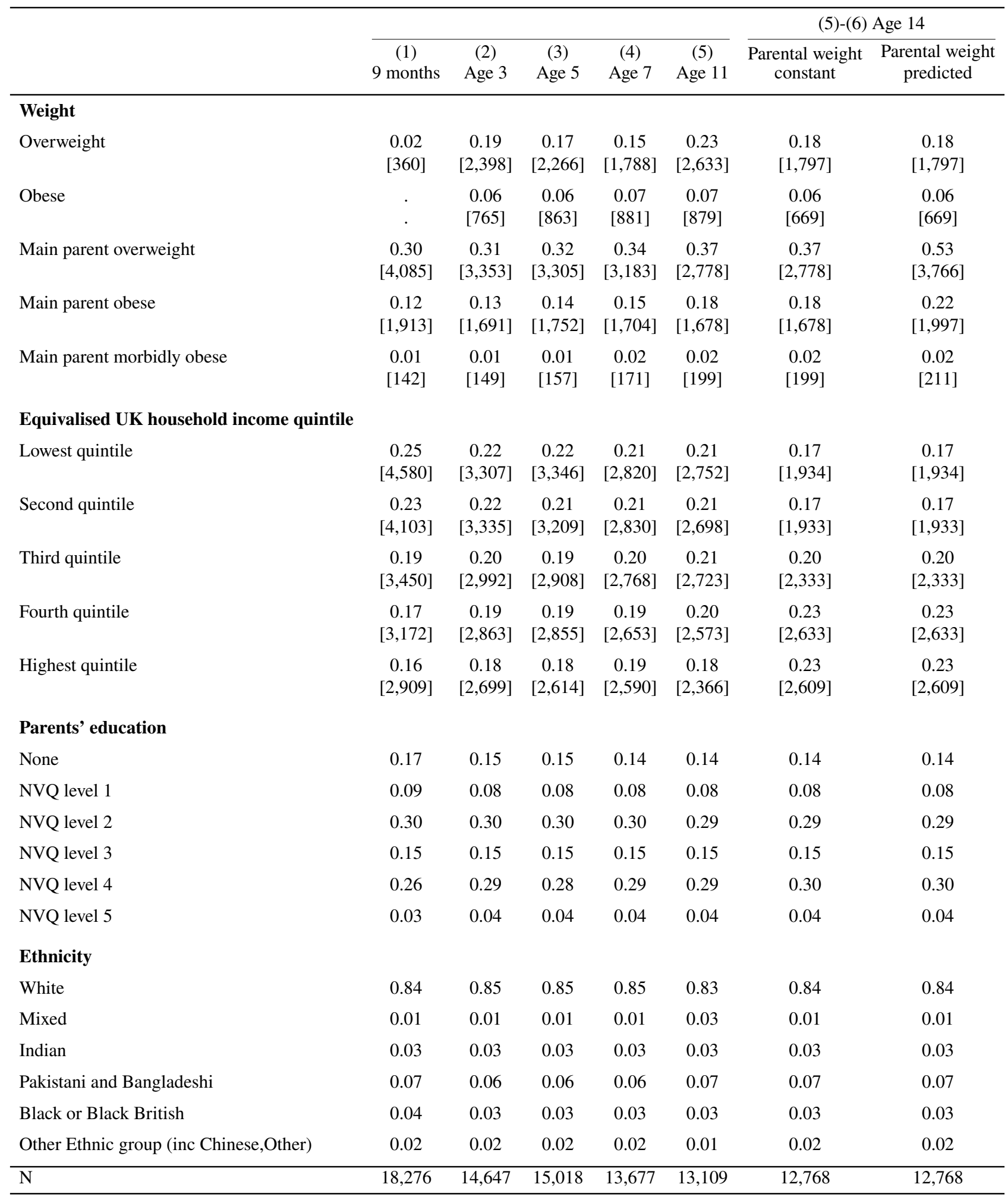

Note: For all variables except income numbers are proportions. Numbers in square brackets are counts. Household income is equivalised using the OECD equivalisation scales, and is in 2010 prices. Exchange rates were retrieved from https://www.bankofengland.co.uk/monetary-policy/inflation/inflation-calculator. The scales adjust income for family size and composition relative to the income of a couple with no children. Hansen et al. (2014) provide detail on the OECD equivalisation used in the MCS, and how it compares to other commonly used scales. 
Table A3: Percent of families in each UK income quintile at age 14, by UK income quintile at age 9 months

\begin{tabular}{|c|c|c|c|c|c|c|c|}
\hline & \multicolumn{7}{|c|}{ UK income quintile age 14} \\
\hline & & 1 & 2 & 3 & 4 & 5 & $\%$ Missing \\
\hline & 1 & 46.90 & 28.75 & 15.50 & 6.34 & 2.52 & 49.72 \\
\hline $\begin{array}{l}\text { UK Income } \\
\text { quintile }\end{array}$ & 2 & 23.49 & 28.02 & 25.99 & 16.55 & 5.95 & 43.46 \\
\hline \multirow[t]{3}{*}{9 months } & 3 & 5.13 & 14.17 & 28.67 & 34.27 & 17.75 & 38.43 \\
\hline & 4 & 1.97 & 6.87 & 19.92 & 34.94 & 36.31 & 31.15 \\
\hline & 5 & 0.97 & 3.52 & 11.63 & 26.21 & 57.67 & 28.77 \\
\hline
\end{tabular}

Note: Each of the first 5 rows/columns indicates the income quintile a family was in when their child was aged 14 given their income quintle at 9 months for those present at both ages. The first 5 columns sum to $100 \%$ for each row. \% Missing represents to proportion in each income quintile at 9 months who were not present at age 14. Income quintiles are defined out of sample relative the the UK household income distribution.

Table A4: Percent of parents overweight or obese at age 11, by weight at age 9 months

\begin{tabular}{ccccccc}
\hline \multicolumn{7}{c}{ Parental weight at age 11 } \\
\hline & & Normal range & Overweight & Obese & Morbidly obese & \% Missing \\
Parental & Normal range & 73.51 & 22.24 & 4.00 & 0.25 & 46.57 \\
weight & Overweight & 16.59 & 53.72 & 28.61 & 1.07 & 49.69 \\
& Obese & 2.74 & 21.80 & 65.18 & 10.27 & 54.18 \\
& Morbidly obese & 0 & 1.52 & 34.85 & 63.64 & 53.52 \\
\hline
\end{tabular}

Note: Each of the first 4 rows/columns indicates the BMI range of parents' weight when their child was aged 11 given their category at 9 months for those present at both ages. The first 4 columns sum to $100 \%$ for each row. $\%$ Missing represents to proportion in each category at 9 months who were not present at age 11. Overweight is defined by having a BMI of between 25 and 30, obesit between 30 and 40, and morbid obesity above 40 . 
Table A5: The early predictors of obesity and overweight at age 14

\begin{tabular}{|c|c|c|c|c|}
\hline & \multicolumn{2}{|c|}{ Weighted } & \multicolumn{2}{|c|}{ Un-weighted } \\
\hline & $\begin{array}{l}\text { (1) } \\
\text { Obese }\end{array}$ & $\begin{array}{c}\text { (2) } \\
\text { Overweight }\end{array}$ & $\begin{array}{l}\text { (1) } \\
\text { Obese }\end{array}$ & $\begin{array}{c}\text { (2) } \\
\text { Overweight }\end{array}$ \\
\hline Main parent overweight at 9 months & $\begin{array}{l}0.047^{* * *} \\
(0.000)\end{array}$ & $\begin{array}{l}0.107^{* * *} \\
(0.000)\end{array}$ & $\begin{array}{l}0.043^{* * *} \\
(0.000)\end{array}$ & $\begin{array}{l}0.107^{* * *} \\
(0.000)\end{array}$ \\
\hline Main parent obese at 9 months & $\begin{array}{l}0.117^{* * *} \\
(0.000)\end{array}$ & $\begin{array}{l}0.186^{* * *} \\
(0.000)\end{array}$ & $\begin{array}{l}0.108^{* * *} \\
(0.000)\end{array}$ & $\begin{array}{l}0.213^{* * *} \\
(0.000)\end{array}$ \\
\hline \multicolumn{5}{|l|}{ Income quintiles } \\
\hline Lowest quintile & $\begin{array}{l}0.044^{* * *} \\
(0.000)\end{array}$ & $\begin{array}{l}0.076^{* * *} \\
(0.000)\end{array}$ & $\begin{array}{l}0.034^{* * *} \\
(0.000)\end{array}$ & $\begin{array}{l}0.061^{* * *} \\
(0.000)\end{array}$ \\
\hline Second quintile & $\begin{array}{l}0.032^{* * *} \\
(0.001)\end{array}$ & $\begin{array}{c}0.043^{* *} \\
(0.018)\end{array}$ & $\begin{array}{l}0.029^{* * *} \\
(0.000)\end{array}$ & $\begin{array}{c}0.026^{*} \\
(0.069)\end{array}$ \\
\hline Third quintile & $\begin{array}{c}-0.002 \\
(0.728)\end{array}$ & $\begin{array}{l}0.046^{* * *} \\
(0.005)\end{array}$ & $\begin{array}{c}0.013^{* *} \\
(0.039)\end{array}$ & $\begin{array}{l}0.044^{* * *} \\
(0.001)\end{array}$ \\
\hline Fourth quintile & $\begin{array}{c}0.006 \\
(0.444)\end{array}$ & $\begin{array}{c}0.023 \\
(0.107)\end{array}$ & $\begin{array}{c}0.006 \\
(0.286)\end{array}$ & $\begin{array}{c}0.027^{* *} \\
(0.030)\end{array}$ \\
\hline $\mathbb{E}[\operatorname{Pr}($ outcome $) \mid x]$ & 0.043 & 0.169 & 0.043 & 0.163 \\
\hline $\mathrm{N}$ & 8,663 & 8,142 & 8,664 & 8,143 \\
\hline
\end{tabular}

Note: $*$,**, and $* * *$ denote statistical significance at $10 \%, 5 \%$ and $1 \%$ respectively. The effects reported are marginal effects from a logit regression with the outcomes being whether a child is obese (column $1 \& 3$ ) or overweight (column 2 $\& 4)$ at age 14. Family income is equivalised to adjust for household composition using the OECD equivalisation scales (Hansen et al., 2014). All observations in columns 1 and 2 are adjusted for the probability of attrition and being sampled, see (Hansen et al., 2014). The omitted income category is the fifth quintile. Quintiles are relative to the distribution of income in the UK. The regression also controlled for gender, birthweight, weight gain between birth and 9 months, ethnicity, the number of siblings in the household and the parent's age at birth, level of education, and whether of not they have a long-term illness. All are fixed at their means in predicting the marginal effects reported. The main parent is the survey respondent, and is the mother for over $99 \%$ of children at 9 months. $\mathrm{N}$ differs between columns because the outcome in column 2 excludes obese children. 


\section{A.2 Constructing a healthy behaviour index}

Tables A6(a) and A6(b) show how indicators of healthy behaviour were created from MCS variables in each round. From these measures we construct an overall index of healthy behaviour based on the number of healthy habits children are reported to have. As the number, type, and coding of measures differs across ages, so does our threshold for satisfying the index. We define children as having "healthy beaviour" if they have all three behaviours at age 3; four or more at ages 5, 7, and 14; and five at 11 .

\section{Table A6(a): Notes on MCS variables used as measures of healthy behaviours}

\begin{tabular}{|c|c|c|}
\hline MCS variable & Responses & Indicator created \\
\hline \multicolumn{3}{|l|}{ Age 3} \\
\hline$\overline{\text { Child }}$ has fruit/vegetables once a day & 0/1: no/yes & Variable used as it was \\
\hline Child has regular meal times & $\begin{array}{l}1 / 2 / 3 / 4: \text { never or almost } \\
\text { never/sometimes/ usually/always }\end{array}$ & Child always has regular meals \\
\hline Someone does sport with the child & 0/1: no/yes & Variable used as it was \\
\hline \multicolumn{3}{|l|}{ Age 5} \\
\hline$\overline{\text { Portions of fruit/vegetables a day }}$ & $\begin{array}{l}0 / 1 / 2 / 3: \text { none/one/two/three or } \\
\text { more }\end{array}$ & $\begin{array}{l}\text { Child has three portions of } \\
\text { fruit/veg. a day }\end{array}$ \\
\hline Child has regular meal times & See variable at age 3 & Child always has regular meals \\
\hline How often plays physically active games & $\begin{array}{l}1 / 2 / 3 / 4 / 5 / 6: \text { not at all/less } \\
\text { often/once or twice a } \\
\text { month/once or twice a } \\
\text { week/several times a week/every } \\
\text { day }\end{array}$ & $\begin{array}{l}\text { Plays physically active games } \\
\text { with child once a week }\end{array}$ \\
\hline Days per week child does sport/exercise & $\begin{array}{l}\text { 1/2/3/4/5/7: less often or not at } \\
\text { all/one day/two days/three } \\
\text { days/four days/five or more days }\end{array}$ & \\
\hline How often child does sport/exercise with family & $\begin{array}{l}\text { 1/2/3/4/5/6/7: less often or } \\
\text { never/once a year/every few } \\
\text { months/once a month/once or } \\
\text { twice a week/several times a } \\
\text { week/every day }\end{array}$ & $\begin{array}{l}\text { Parent does sport/exercise with } \\
\text { child at least once a week }\end{array}$ \\
\hline \multicolumn{3}{|l|}{ Age 7} \\
\hline$\overline{\text { How }}$ often child eats fruit/vegetables & See variable at age 5 & \\
\hline Child has regular meal times & See variable at age 3 & \\
\hline How often plays physically active games & See variable at age 5 & \\
\hline Days per week child does sport/exercise & See variable at age 5 & \\
\hline How often parent does sport/exercise with child & $\begin{array}{l}1 / 2 / 3 / 4 / 5 / 6: \text { not at all/less than } \\
\text { once a month/once or twice a } \\
\text { month/once or twice a } \\
\text { week/several times a week/every } \\
\text { day or almost every day }\end{array}$ & \\
\hline
\end{tabular}




\section{Table A6(b): Notes on MCS variables used as measures of healthy behaviours cont.}

\begin{tabular}{|c|c|c|}
\hline MCS variable & Responses & Indicator created \\
\hline \multicolumn{3}{|l|}{ Age 11} \\
\hline$\overline{\text { How often child eats fruit/vegetables }}$ & See variable at age 5 & \\
\hline How often parent does sport/exercise with child & See variable at age 7 & \\
\hline Days per week child does sport/exercise & See variable at age 5 & \\
\hline Days per week child does physical activities & $\begin{array}{l}\text { 1/2/3/4/5/6/7: not at all/less } \\
\text { often than once a week/one } \\
\text { day/two days/three days/four } \\
\text { days/five or more days }\end{array}$ & $\begin{array}{l}\text { Child plays physically active } \\
\text { games at least once a week }\end{array}$ \\
\hline Days per week child has breakfast & $1 / 2 / 3 / 4 / 5 / 6 / 7$ & Child has breakfast every day \\
\hline How often drinks sweetened drinks & $\begin{array}{l}\text { 1/2/3/4/5/6/7: more than once a } \\
\text { day/once a day/3-6 days a } \\
\text { week/1-2 days/once a month/less } \\
\text { than once a month/never }\end{array}$ & $\begin{array}{l}\text { Child drinks sweetened drinks } \\
\text { less than once a day }\end{array}$ \\
\hline How often drinks artificially sweetened drinks & $\begin{array}{l}\text { 1/2/3/4/5/6/7: more than once a } \\
\text { day/once a day/3-6 days a } \\
\text { week/1-2 days/once a month/less } \\
\text { than once a month/never }\end{array}$ & $\begin{array}{l}\text { Child drinks artificially } \\
\text { sweetened drinks less than once } \\
\text { a day }\end{array}$ \\
\hline \multicolumn{3}{|l|}{ Age 14} \\
\hline How often child two portions of fruit/vegetables & $\begin{array}{l}\text { 1/2/3: never/some days/every } \\
\text { day }\end{array}$ & \\
\hline Days per week child eats breakfast & $1 / 2 / 3 / 4 / 5 / 6 / 7$ & \\
\hline How often drinks sweetened drinks & See variable at age 11 & \\
\hline How often drinks artificially sweetened drinks & See variable at age 11 & \\
\hline How often has fast food & $\begin{array}{l}\text { 1/2/3/4/5/6/7: more than once a } \\
\text { day/once a day/3- } 6 \text { days a } \\
\text { week/1-2 days/once a month/less } \\
\text { than once a month/never }\end{array}$ & $\begin{array}{l}\text { child has fast food less than once } \\
\text { a month }\end{array}$ \\
\hline
\end{tabular}




\section{A.3 Additional figures on height and weight across rounds of the MCS}

Figure A1: Overweight and obesity across childhood in the MCS in the top and bottom income quintiles

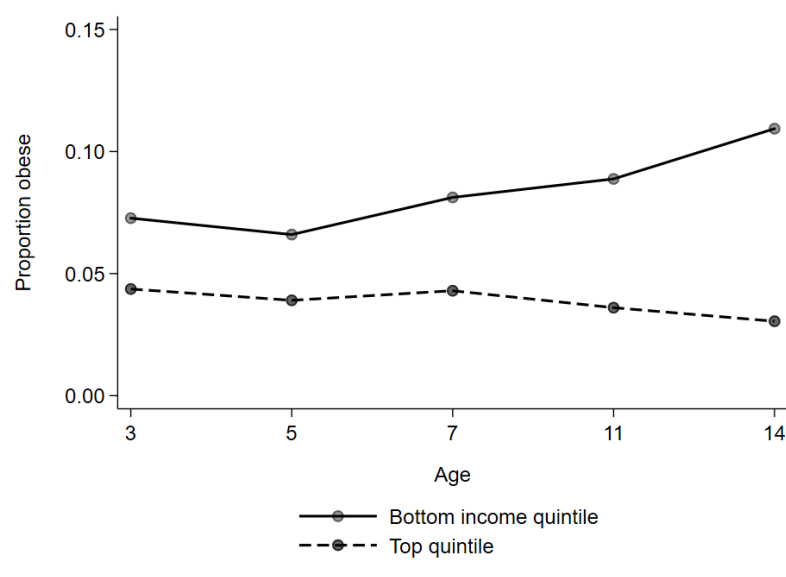

(a) Obesity

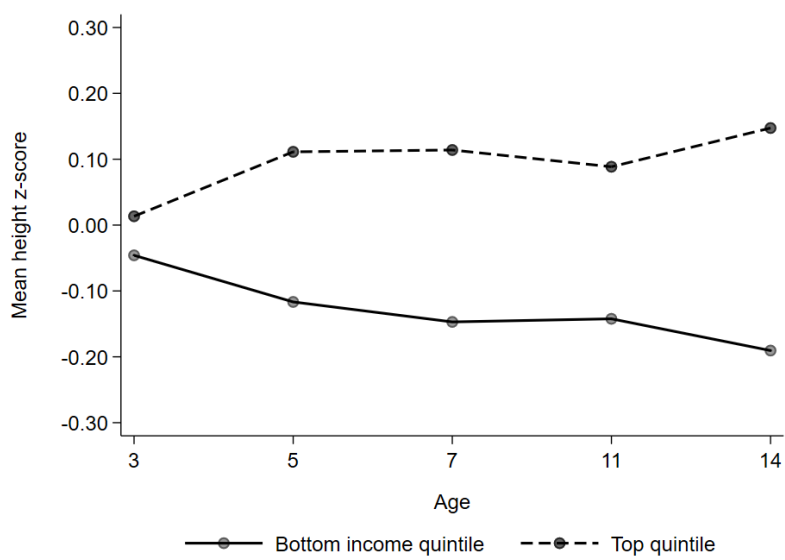

(c) Height z-score

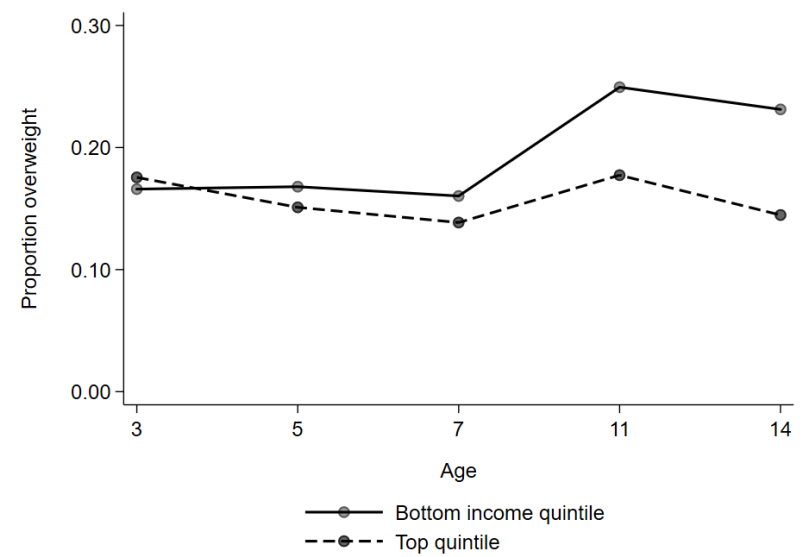

(b) Overweight

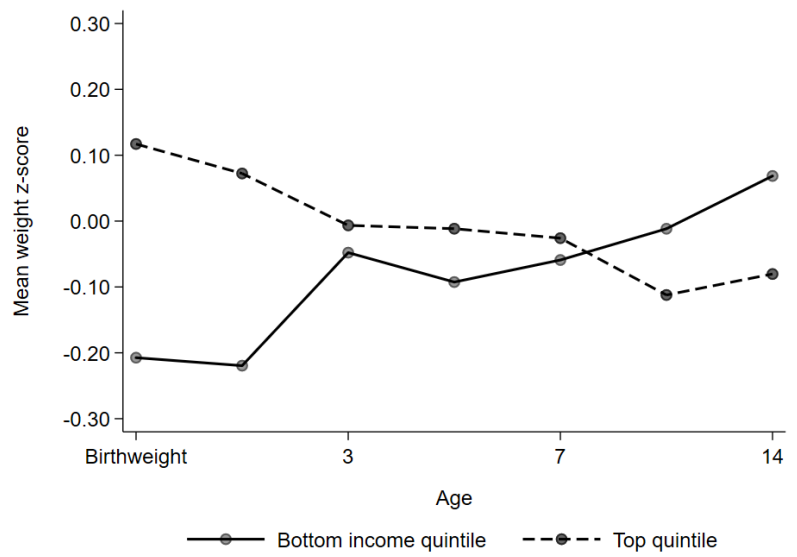

(d) weight z-score

Note: Income quintiles are relative to the UK income distribution are defined in sample using households' equivalised income, calculated using the OECD equivalisation scales to adjust for family size and composition. Panel (a) shows the proportion of children at each age that classified as obese and panel (b) the proportion classified overweight. Both definitions are based on the International Obesity Task Force age-specific BMI thresholds (see Table A1). Panel (c) shows the the average height Z-score of children and panel (d) the average weight Z-score in each of these quintiles at each age. For comparability, the sample includes 11,714 children who remained in the sample across all waves. 


\section{Figure A2: Obesity across waves in the MCS in the top and bottom income quintiles}

at age 9 months

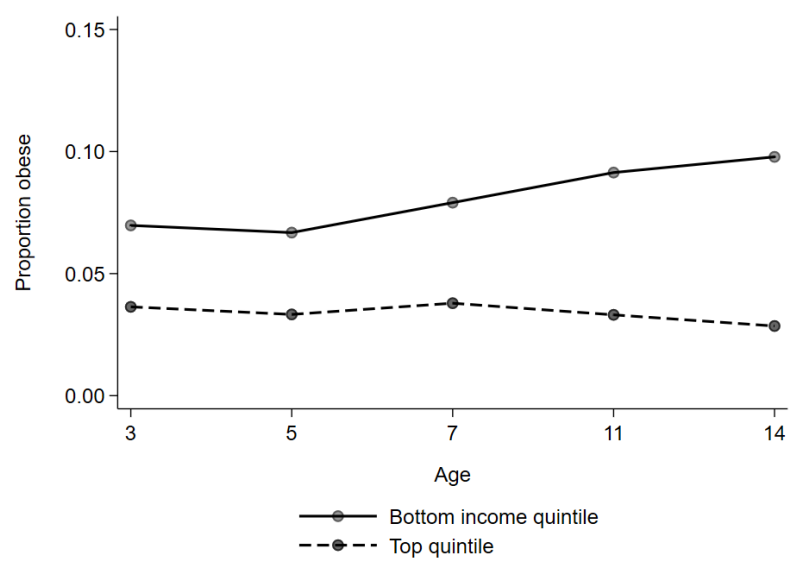

(a)

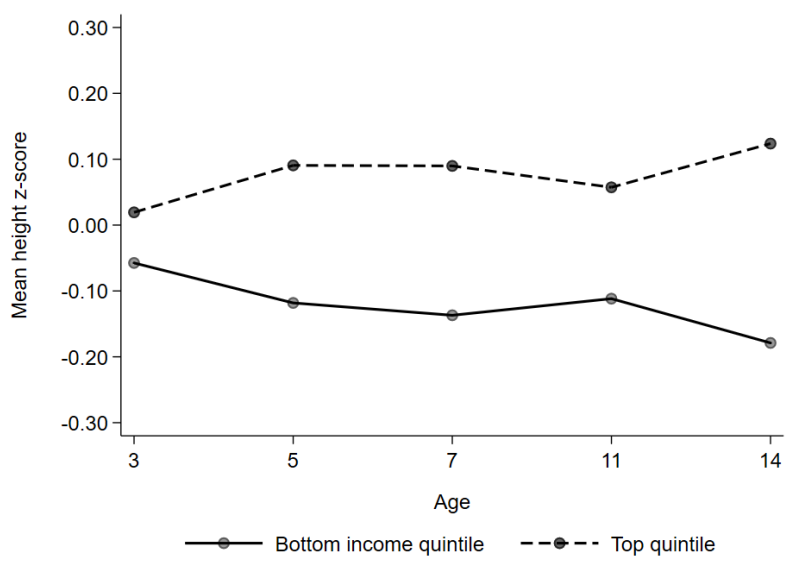

(c)

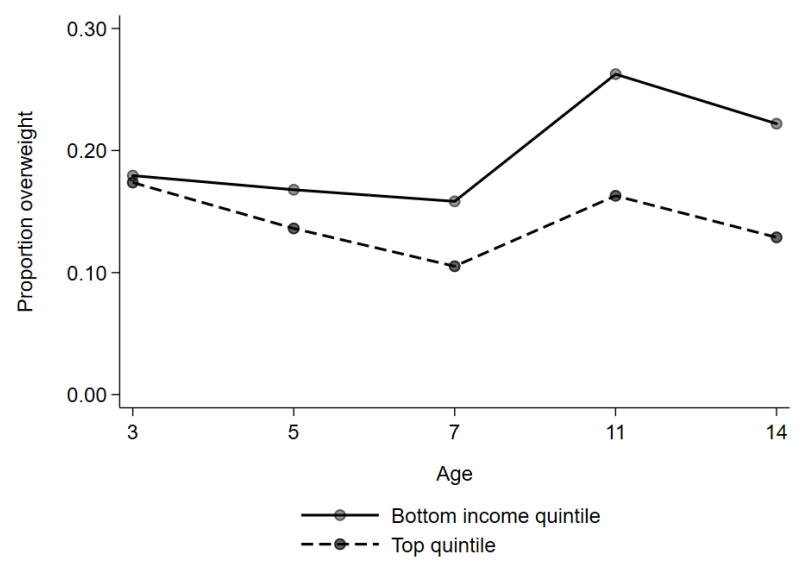

(b)

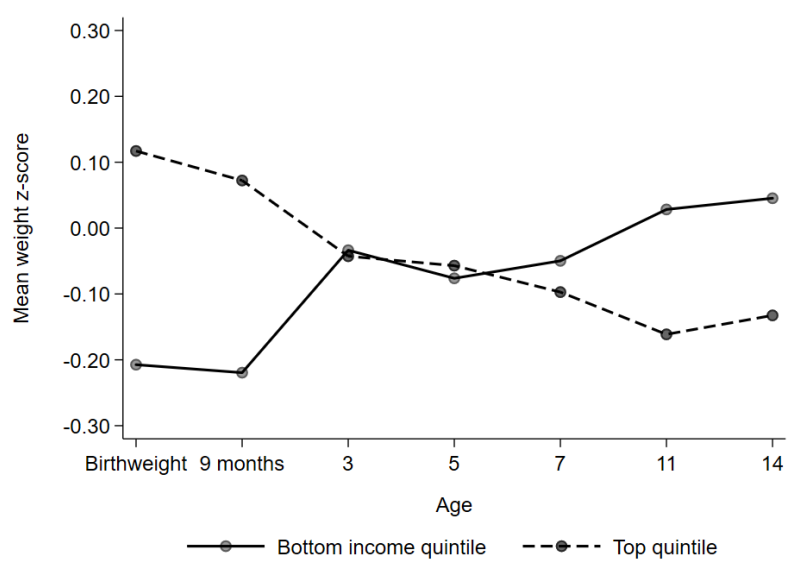

(d)

Note: Income quintiles are relative to the UK income distribution are defined in sample using households' equivalised income, calculated using the OECD equivalisation scales to adjust for family size and composition. Income is fixed at its level when children were 9 months old. Panel (a) shows the proportion of children at each age classified as obese and panel (b) the proportion classified overweight. Both definitions are based on the International Obesity Task Force age-specific BMI thresholds (see Table A1). Panel (c) shows the the average height Z-score of children and panel (d) the average weight $\mathrm{Z}$-score in each of these quintiles at each age. For comparability, the sample includes children who remained in the sample across all waves. 
Figure A3: Obesity and overweight across waves in the MCS, by main parent's weight category

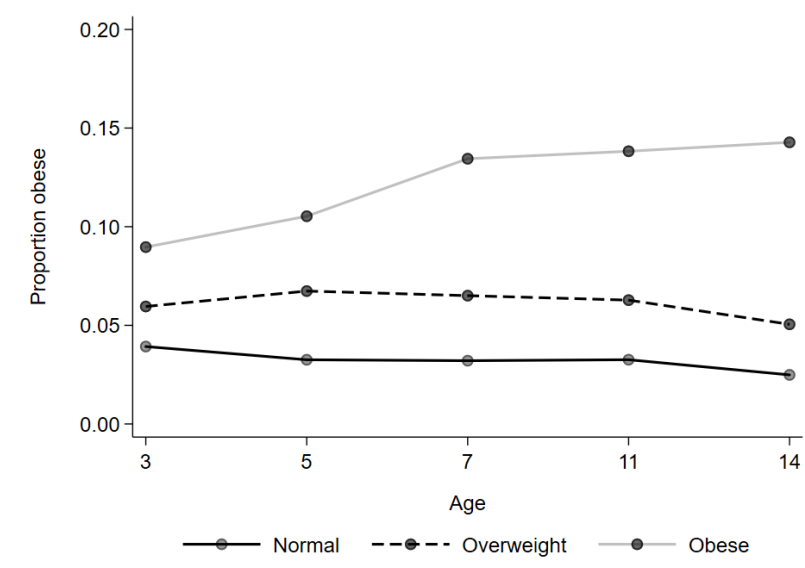

(a)

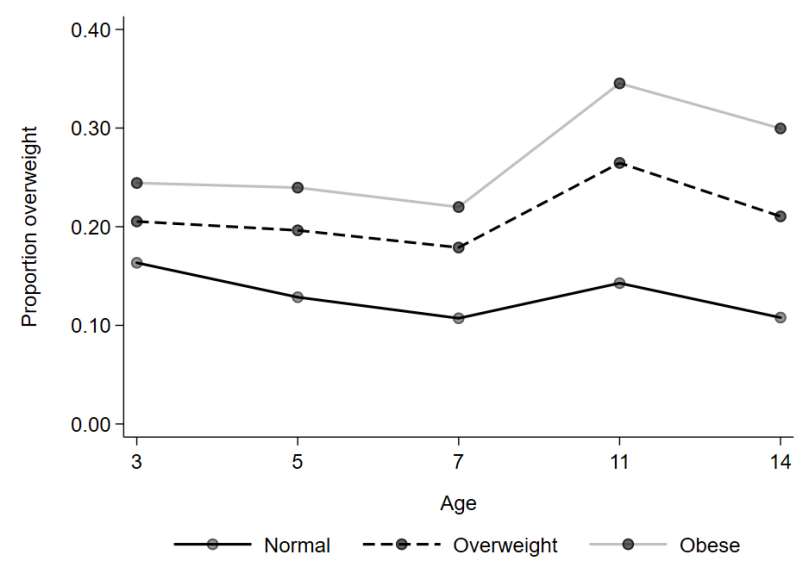

(b)

Note: Panel (a) shows the proportion of children at each age classified as obese and panel (b) the proportion classified overweight based on whether or not their parents are either overweight or obese. Definitions of overweight and obesity for children are based on the International Obesity Task Force age-specific BMI thresholds (see Table A1). For parents obesity is defined by having a BMI of between 30 and 40, and morbid obesity as a BMI above 40. For comparability, the sample includes parents of children who remained in the sample across all waves. 
Figure A4: Overweight and obesity of parents across waves in the MCS, by income quintile

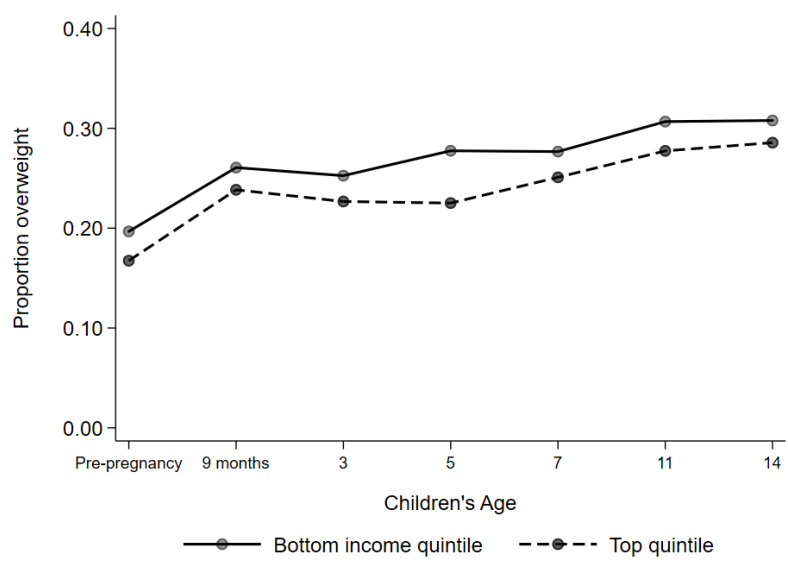

(a) Income varying over time

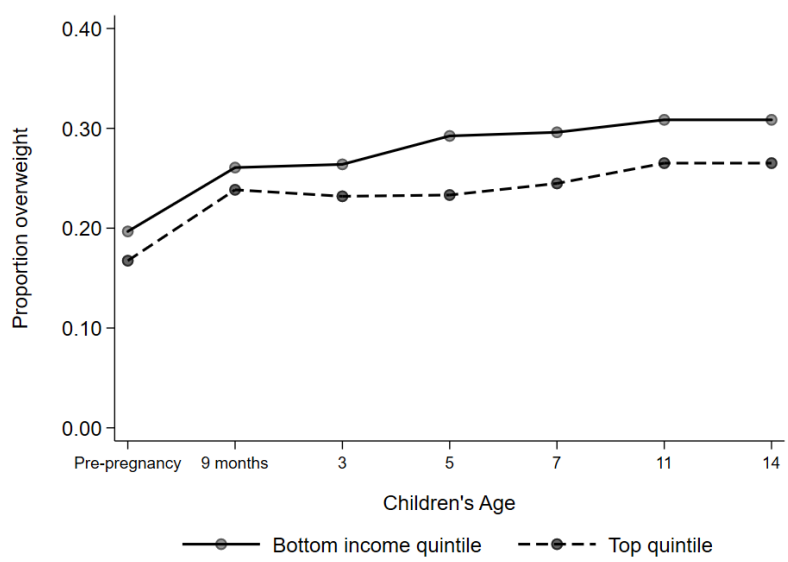

(c) Income fixed at 9 months

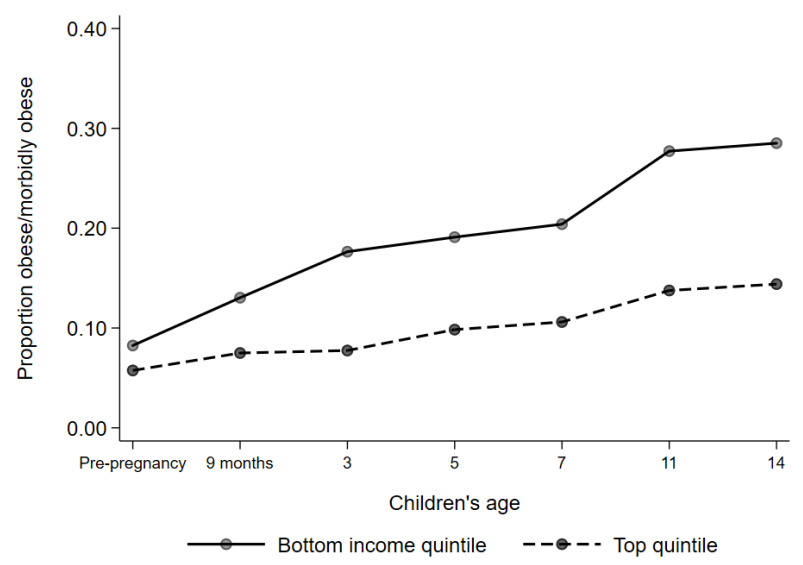

(b) Income varying over time

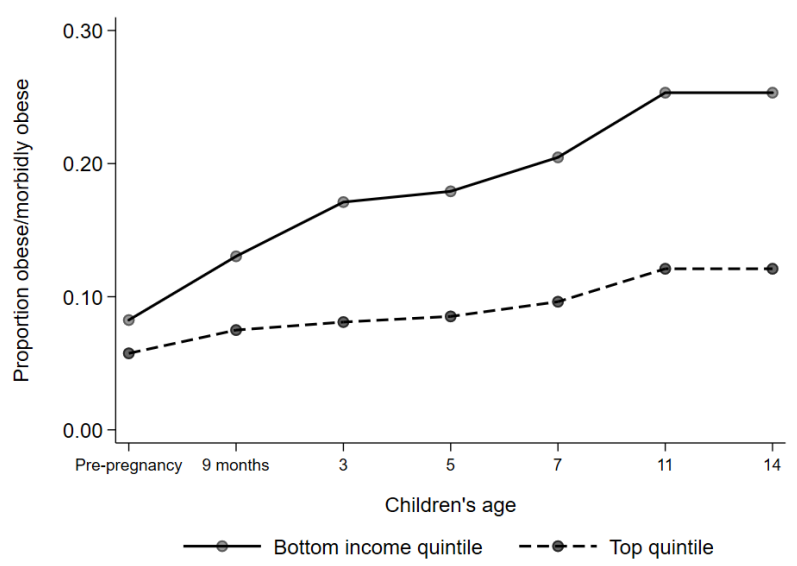

(d) Income fixed at 9 months

Note: Income quintiles are relative to the UK income distribution are defined in sample using households' equivalised income, calculated using the OECD equivalisation scales to adjust for family size and composition. In panels (a) and (b) quintiles are re-calculated at each age. In panels (c) and (d) they are fixed at their 9-months value. Panels (a) and (c) shows the proportion parents at each age that classified as obese and panel (b) and (d) the proportion classified morbidly obese. Overweight is defined by having a BMI of between 30 and 40, and obesity as a BMI above 40. For comparability, the sample includes parents of children who remained in the sample across all waves. 


\section{A.4 Additional figures on healthy behaviours across rounds}

Figure A5: Proportion of parents reporting diet and exercise related healthy behaviour across waves in the MCS, by whether a child is overweight or obese at 14

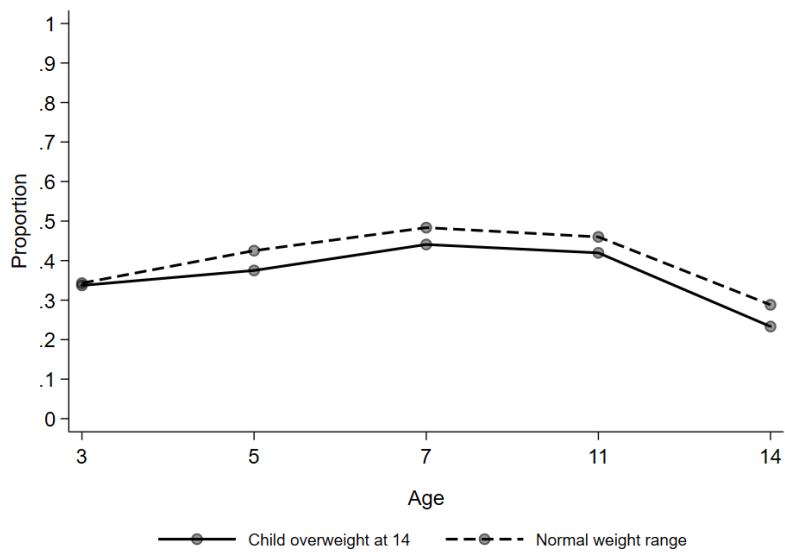

(a) Overweight at 14

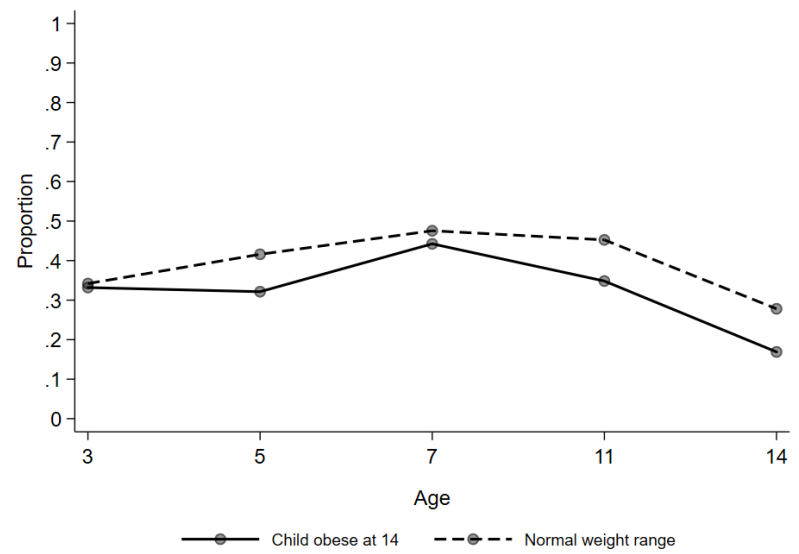

(b) Obese at 14

Note: The y axis on both panels is the proportion children engaging in one diet based and one exercise based healthy behaviour. Measures of healthy behaviours are described in Table A6(a). Panel a charts this outcome by whether or not children are overweight at 14 and panel b by whether they are obese. Both definitions are based on the International Obesity Task Force age-specific BMI thresholds (see Table A1).

Figure A6: Proportion of parents reporting diet and exercise related healthy behaviour across waves in the MCS, by parents' weight and income

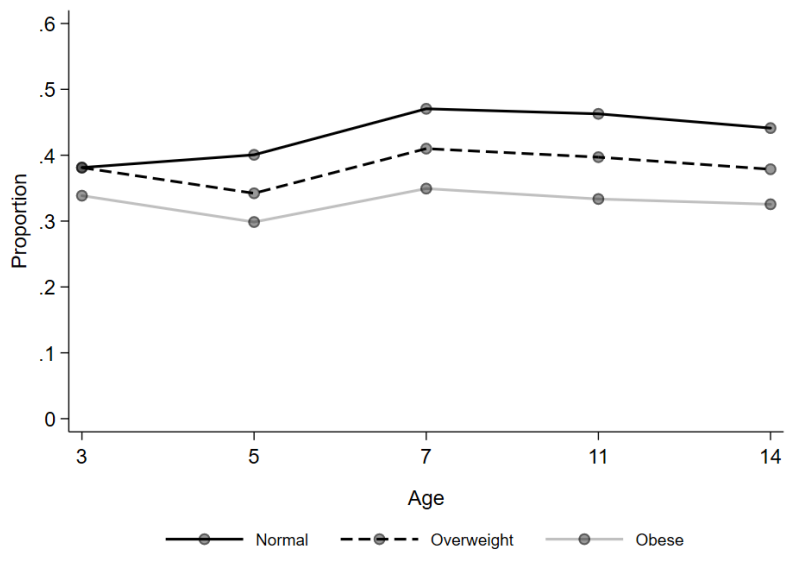

(a) By whether or not parent is obese

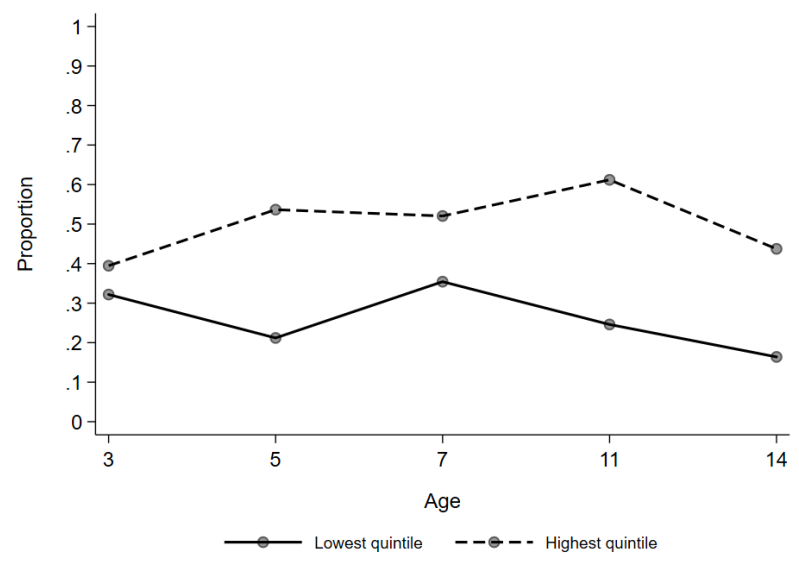

(b) In the highest and lowest income quintile

Note: The y axis on all panels is the proportion children engaging in one diet based and one exercise based healthy behaviour. Measures of healthy behaviours are described in Table A6(a). Panels a and b chart this outcome by whether or not parents are overweight or obese respectively. Obesity is defined by having a BMI of between 30 and 40, and morbid obesity as a BMI above 40. In panel (c) Income quintiles are relative to the UK income distribution at each age. Income is adjusted for household composition using the OECD equivalisation scales. For comparability, the sample includes parents of children who remained in the sample across all waves. 


\section{A.5 Predicting parents' weight at age 14}

The MCS does not have weight or height information on parents when children are age 14. We therefore estimate how parents weight evolves over childhood using the following equation:

$$
M P W_{i t}=\beta_{0}+\beta_{1} M P W_{i t-1}+\beta_{2} M P H e i g h t_{i t}+\beta_{3} t+\beta_{4} t^{2}+\varepsilon_{i t},
$$

where $M P W_{i t}$ is the weight of the main parent in kilograms, $M P W_{i t-1}$ is lagged weight, MPHeight $t_{i t}$ is height in metres, $t$ and $t^{2}$ represent a quadratic time-trend, and $\beta_{0}$ is a constant. We do not explicitly model individual heterogeneity here since we are not interested in strictly interpreting the parameters themselves. We estimate the parameters of this equation using information on parents' weight from pre-pregnancy to age 11 - the MCS asks respondents their BMI before pregnancy from which we are able to calculate their weight in kilograms pre-pregnancy, given that height is constant across rounds. Table A7 shows these estimates, and Figures A7(a)-A7(c) respectively show plots of the residuals versus fitted values, density of the residuals, and the correlation between actual and predicted values of parents weight from this regression. We then use the parameters in Table A7 to predict parents' weight when children are aged 14.

Table A7: Determinants of parental weight across childhood

\begin{tabular}{lc}
\hline & $\beta$ \\
\hline Lagged weight & $0.892^{* * *}$ \\
& $(0.007)$ \\
Height in metres & $5.138^{* * *}$ \\
& $(0.669)$ \\
Linear trend & $-2.267 * * *$ \\
& $(0.422)$ \\
Quadratic & $0.307 * * *$ \\
& $(0.048)$ \\
Constant & $3.216^{*}$ \\
& $(1.283)$ \\
\hline Observations & 19,245 \\
R-Squared & 0.770 \\
\hline
\end{tabular}

Note: ***,**, and * represent statistical significance at $1 \%, 5 \%$, and $10 \%$ respectively. Standard errors in parentheses are clustered at the individual level. The outcome is weight in kilograms. 
Figure A7: Properties of the residuals and fitted values from estimating the determinants of parental weight from pre-pregnancy to age 11

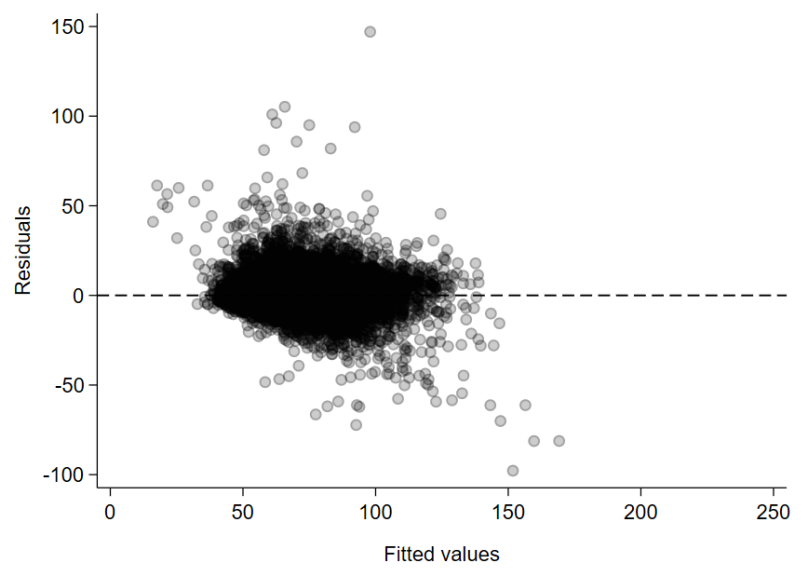

(a) Residuals versus fitted values

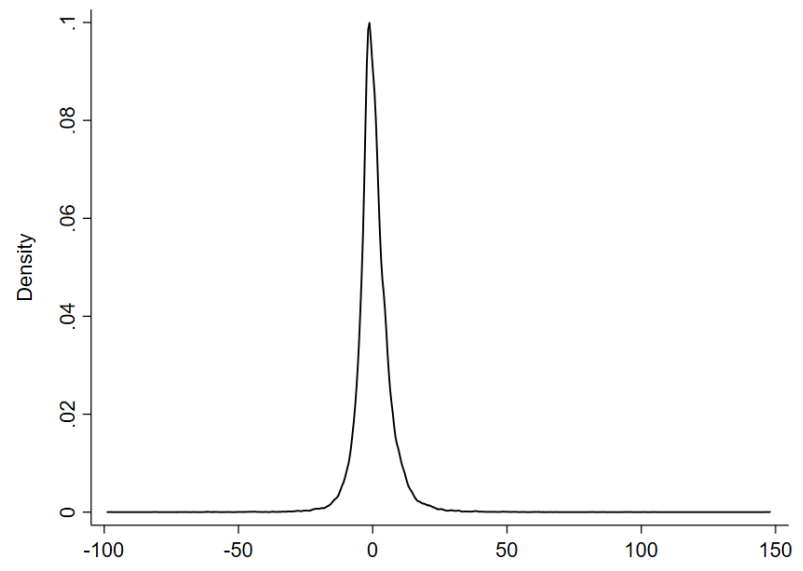

(b) Residual distribution

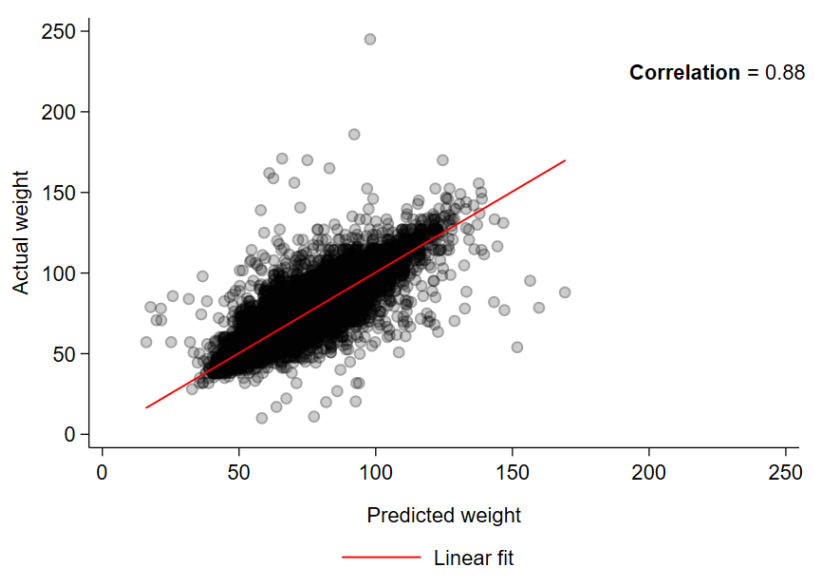

(c) Actual versus fitted values

Note: All panels use residuals and/or fitted values from estimating how lagged weight, height, and a quadratic time-trend explain parents' weight from pre-pregnancy to when children are aged 11 (Equation A6). Results of this regression are shown in Table A7. 


\section{B Additional results}

B.1 Additional tables on the determinants of overweight and obesity 
Table B1: The determinants of child overweight and obesity across childhood, using restricted sample and not adjusting for attrition or sample design

\begin{tabular}{|c|c|c|c|c|c|c|}
\hline & & & & & \multicolumn{2}{|c|}{ (5)-(6) Age 14} \\
\hline & $\begin{array}{c}(1) \\
\text { Age } 3\end{array}$ & $\begin{array}{l}\text { (2) } \\
\text { Age } 5\end{array}$ & $\begin{array}{c}(3) \\
\text { Age } 7\end{array}$ & $\begin{array}{c}(4) \\
\text { Age } 11\end{array}$ & $\begin{array}{l}\text { Parental weight } \\
\text { constant }\end{array}$ & $\begin{array}{l}\text { Parental weight } \\
\text { predicted }\end{array}$ \\
\hline \multicolumn{7}{|l|}{ Panel A: Probability of overweight } \\
\hline Main parent overweight & $\begin{array}{l}0.028^{* * *} \\
(0.011)\end{array}$ & $\begin{array}{l}0.058^{* * *} \\
(0.010)\end{array}$ & $\begin{array}{l}0.063^{* * *} \\
(0.009)\end{array}$ & $\begin{array}{l}0.113^{* * *} \\
(0.011)\end{array}$ & $\begin{array}{l}0.099^{* * *} \\
(0.010)\end{array}$ & $\begin{array}{l}0.074^{* * *} \\
(0.009)\end{array}$ \\
\hline Main parent obese/morbidly obese & $\begin{array}{l}0.065^{* * *} \\
(0.014)\end{array}$ & $\begin{array}{l}0.100^{* * *} \\
(0.013)\end{array}$ & $\begin{array}{l}0.091^{* * *} \\
(0.013)\end{array}$ & $\begin{array}{l}0.184^{* * *} \\
(0.015)\end{array}$ & $\begin{array}{l}0.171^{* * *} \\
(0.014)\end{array}$ & $\begin{array}{l}0.169^{* * *} \\
(0.013)\end{array}$ \\
\hline \multicolumn{7}{|l|}{ Income quintiles } \\
\hline Lowest quintile & $\begin{array}{c}0.026 \\
(0.017)\end{array}$ & $\begin{array}{l}0.033^{* *} \\
(0.016)\end{array}$ & $\begin{array}{c}0.021 \\
(0.016)\end{array}$ & $\begin{array}{l}0.062^{* * *} \\
(0.023)\end{array}$ & $\begin{array}{l}0.083^{* * *} \\
(0.023)\end{array}$ & $\begin{array}{l}0.085^{* * *} \\
(0.023)\end{array}$ \\
\hline Second quintile & $\begin{array}{c}0.024 \\
(0.015)\end{array}$ & $\begin{array}{c}0.013 \\
(0.014)\end{array}$ & $\begin{array}{c}0.012 \\
(0.014)\end{array}$ & $\begin{array}{l}0.063^{* * *} \\
(0.018)\end{array}$ & $\begin{array}{l}0.040^{* *} \\
(0.017)\end{array}$ & $\begin{array}{l}0.040^{* *} \\
(0.017)\end{array}$ \\
\hline Third quintile & $\begin{array}{r}0.026^{*} \\
(0.014)\end{array}$ & $\begin{array}{c}0.003 \\
(0.012)\end{array}$ & $\begin{array}{c}0.003 \\
(0.013)\end{array}$ & $\begin{array}{l}0.060^{* * *} \\
(0.016)\end{array}$ & $\begin{array}{l}0.044^{* * *} \\
(0.014)\end{array}$ & $\begin{array}{l}0.046^{* * *} \\
(0.014)\end{array}$ \\
\hline Fourth quintile & $\begin{array}{r}0.024^{*} \\
(0.013)\end{array}$ & $\begin{array}{l}0.024^{* *} \\
(0.012)\end{array}$ & $\begin{array}{c}-0.006 \\
(0.012)\end{array}$ & $\begin{array}{l}0.034^{* *} \\
(0.014)\end{array}$ & $\begin{array}{c}0.015 \\
(0.012)\end{array}$ & $\begin{array}{c}0.014 \\
(0.012)\end{array}$ \\
\hline $\begin{array}{l}\mathbb{E}[\operatorname{Pr}(\text { overweight }) \mid x] \\
\mathrm{N}\end{array}$ & $\begin{array}{l}0.162 \\
7,203\end{array}$ & $\begin{array}{l}0.138 \\
7,775\end{array}$ & $\begin{array}{l}0.125 \\
7,462\end{array}$ & $\begin{array}{l}0.199 \\
6,848\end{array}$ & $\begin{array}{l}0.153 \\
6,674\end{array}$ & $\begin{array}{l}0.154 \\
6,674\end{array}$ \\
\hline \multicolumn{7}{|l|}{ Panel B: Probability of obesity } \\
\hline Main parent overweight & $\begin{array}{l}0.014^{* * *} \\
(0.006)\end{array}$ & $\begin{array}{l}0.026^{* * *} \\
(0.006)\end{array}$ & $\begin{array}{l}0.026^{* * *} \\
(0.006)\end{array}$ & $\begin{array}{l}0.026^{* * *} \\
(0.006)\end{array}$ & $\begin{array}{l}0.023^{* * *} \\
(0.005)\end{array}$ & $\begin{array}{l}0.025^{\text {*** }} \\
(0.005)\end{array}$ \\
\hline Main parent obese/morbidly obese & $\begin{array}{l}0.037^{* * *} \\
(0.008)\end{array}$ & $\begin{array}{l}0.054^{* * *} \\
(0.008)\end{array}$ & $\begin{array}{l}0.084^{* * *} \\
(0.009)\end{array}$ & $\begin{array}{l}0.081^{* * * *} \\
(0.009)\end{array}$ & $\begin{array}{l}0.094^{* * *} \\
(0.009)\end{array}$ & $\begin{array}{l}0.092^{* * *} \\
(0.008)\end{array}$ \\
\hline \multicolumn{7}{|l|}{ Income quintiles } \\
\hline Lowest quintile & $\begin{array}{l}0.021^{* *} \\
(0.010)\end{array}$ & $\begin{array}{c}0.010 \\
(0.009)\end{array}$ & $\begin{array}{c}0.010 \\
(0.010)\end{array}$ & $\begin{array}{l}0.027^{* *} \\
(0.013)\end{array}$ & $\begin{array}{l}0.075^{* * *} \\
(0.015)\end{array}$ & $\begin{array}{l}0.076^{* * *} \\
(0.015)\end{array}$ \\
\hline Second quintile & $\begin{array}{c}0.012 \\
(0.008)\end{array}$ & $\begin{array}{c}0.008 \\
(0.008)\end{array}$ & $\begin{array}{c}0.008 \\
(0.009)\end{array}$ & $\begin{array}{l}0.037^{* * *} \\
(0.011)\end{array}$ & $\begin{array}{l}0.036^{* * *} \\
(0.010)\end{array}$ & $\begin{array}{l}0.035^{* * *} \\
(0.010)\end{array}$ \\
\hline Third quintile & $\begin{array}{c}-0.002 \\
(0.007)\end{array}$ & $\begin{array}{c}0.004 \\
(0.008)\end{array}$ & $\begin{array}{c}0.004 \\
(0.008)\end{array}$ & $\begin{array}{l}0.021^{* *} \\
(0.009)\end{array}$ & $\begin{array}{l}0.021^{* * *} \\
(0.007)\end{array}$ & $\begin{array}{l}0.022^{* * *} \\
(0.007)\end{array}$ \\
\hline Fourth quintile & $\begin{array}{c}0.007 \\
(0.008)\end{array}$ & $\begin{array}{c}0.001 \\
(0.008)\end{array}$ & $\begin{array}{c}-0.000 \\
(0.008)\end{array}$ & $\begin{array}{c}0.012 \\
(0.008)\end{array}$ & $\begin{array}{l}0.016^{* *} \\
(0.007)\end{array}$ & $\begin{array}{l}0.016^{* *} \\
(0.007)\end{array}$ \\
\hline $\begin{array}{l}\mathbb{E}[\operatorname{Pr}(\text { obese }) \mid x] \\
\mathrm{N}\end{array}$ & $\begin{array}{l}0.039 \\
7,589\end{array}$ & $\begin{array}{l}0.038 \\
8,193\end{array}$ & $\begin{array}{l}0.042 \\
8,023\end{array}$ & $\begin{array}{l}0.046 \\
7,296\end{array}$ & $\begin{array}{l}0.038 \\
7,067\end{array}$ & $\begin{array}{l}0.038 \\
7,067\end{array}$ \\
\hline \multicolumn{7}{|c|}{ Panel B: Probability of overweight or obesity } \\
\hline Main parent overweight & $\begin{array}{l}0.036^{* * *} \\
(0.011)\end{array}$ & $\begin{array}{l}0.074^{* * *} \\
(0.010)\end{array}$ & $\begin{array}{l}0.079^{* * *} \\
(0.010)\end{array}$ & $\begin{array}{l}0.126^{* * *} \\
(0.012)\end{array}$ & $\begin{array}{l}0.114^{* * *} \\
(0.011)\end{array}$ & $\begin{array}{l}0.092^{* * *} \\
(0.010)\end{array}$ \\
\hline Main parent obese/morbidly obese & $\begin{array}{l}0.087^{* * *} \\
(0.014)\end{array}$ & $\begin{array}{l}0.135^{* * *} \\
(0.014)\end{array}$ & $\begin{array}{l}0.152^{* * *} \\
(0.013)\end{array}$ & $\begin{array}{l}0.233^{* * *} \\
(0.015)\end{array}$ & $\begin{array}{l}0.234^{* * *} \\
(0.014)\end{array}$ & $\begin{array}{l}0.232^{* * * *} \\
(0.014)\end{array}$ \\
\hline \multicolumn{7}{|l|}{ Income quintiles } \\
\hline Lowest quintile & $\begin{array}{l}0.044^{* *} \\
(0.017)\end{array}$ & $\begin{array}{l}0.038^{* *} \\
(0.016)\end{array}$ & $\begin{array}{r}0.029^{*} \\
(0.017)\end{array}$ & $\begin{array}{l}0.080^{* * *} \\
(0.024)\end{array}$ & $\begin{array}{l}0.134^{* * *} \\
(0.023)\end{array}$ & $\begin{array}{l}0.136^{* * *} \\
(0.023)\end{array}$ \\
\hline Second quintile & $\begin{array}{r}0.030^{*} \\
(0.015)\end{array}$ & $\begin{array}{c}0.020 \\
(0.015)\end{array}$ & $\begin{array}{c}0.016 \\
(0.015)\end{array}$ & $\begin{array}{l}0.087^{* * *} \\
(0.019)\end{array}$ & $\begin{array}{l}0.066^{* * *} \\
(0.017)\end{array}$ & $\begin{array}{l}0.065^{* * *} \\
(0.017)\end{array}$ \\
\hline Third quintile & $\begin{array}{r}0.024^{*} \\
(0.014)\end{array}$ & $\begin{array}{c}0.006 \\
(0.013)\end{array}$ & $\begin{array}{c}0.006 \\
(0.014)\end{array}$ & $\begin{array}{l}0.072^{* * *} \\
(0.016)\end{array}$ & $\begin{array}{l}0.058^{* * *} \\
(0.014)\end{array}$ & $\begin{array}{l}0.060^{* * *} \\
(0.014)\end{array}$ \\
\hline Fourth quintile & $\begin{array}{r}0.026^{*} \\
(0.014)\end{array}$ & $\begin{array}{r}0.024^{*} \\
(0.013)\end{array}$ & $\begin{array}{c}-0.006 \\
(0.013)\end{array}$ & $\begin{array}{l}0.039^{* * *} \\
(0.015)\end{array}$ & $\begin{array}{l}0.027^{* *} \\
(0.013)\end{array}$ & $\begin{array}{l}0.026^{* *} \\
(0.013)\end{array}$ \\
\hline $\mathbb{E}[\operatorname{Pr}($ overweight $\cup$ obese $) \mid x]$ & 0.201 & 0.178 & 0.167 & 0.244 & 0.193 & 0.193 \\
\hline $\mathrm{N}$ & 7,589 & 8,193 & 8,023 & 7,296 & 7,067 & 7,067 \\
\hline
\end{tabular}

Note: $* * *$ and $* * *$ denote statistical significance it $10 \%, 5 \%$ and $1 \%$ respectively. The outcome in each column is indicated by Panels A-C, defined using the the IOTF cutoffs (Table A1). The effects reported are marginal effects obtained after estimating Equation 2 fixing the independent variables at their sample mean. The MCS data do not contain parents' BMI at age 14, so columns 5 and 6 use BMI from age 11 or as predicted to define obesity. The omitted income category is the highest quintile. All regressions also controlled for children's gender, birthweight, weight gain between birth and 9 months, whether they have a long-term illness and the number of health conditions reported, ethnicity, the number of siblings in the household, and the parent's level of education and whether they have a long-term illness. Appendix Tables B2-B4 show full results. $\mathbb{E}[\operatorname{Pr}($ outcome $) \mid \boldsymbol{x}]$ represents the estimated conditional expectation of each outcome. The main parent is the mother for $99 \%$ of children at 9 months. Ns differ in Panel A because these regressions exclude obese children. Ns differ across columns because of missing data. 
Table B2: The determinants of child overweight across childhood with controls

\begin{tabular}{|c|c|c|c|c|c|c|}
\hline & \multirow[b]{2}{*}{$\begin{array}{c}(1) \\
\text { Age } 3\end{array}$} & \multirow[b]{2}{*}{$\begin{array}{c}(2) \\
\text { Age } 5\end{array}$} & \multirow[b]{2}{*}{$\begin{array}{c}(3) \\
\text { Age } 7\end{array}$} & \multirow[b]{2}{*}{$\begin{array}{c}\text { (4) } \\
\text { Age } 11\end{array}$} & \multicolumn{2}{|c|}{ (5)-(6) Age 14} \\
\hline & & & & & $\begin{array}{l}\text { Parental weight } \\
\text { constant }\end{array}$ & $\begin{array}{l}\text { Parental weight } \\
\text { predicted }\end{array}$ \\
\hline Main parent overweight & $\begin{array}{l}0.022^{* *} \\
(0.010)\end{array}$ & $\begin{array}{l}0.061^{* * *} \\
(0.010)\end{array}$ & $\begin{array}{l}0.065^{* * *} \\
(0.010)\end{array}$ & $\begin{array}{l}0.101^{* * *} \\
(0.012)\end{array}$ & $\begin{array}{l}0.105^{* * *} \\
(0.014)\end{array}$ & $\begin{array}{l}0.074^{* * *} \\
(0.012)\end{array}$ \\
\hline Main parent obese/morbidly obese & $\begin{array}{l}0.062^{* * *} \\
(0.014)\end{array}$ & $\begin{array}{l}0.126^{* * *} \\
(0.014)\end{array}$ & $\begin{array}{l}0.097^{* * *} \\
(0.013)\end{array}$ & $\begin{array}{l}0.197^{* * *} \\
(0.016)\end{array}$ & $\begin{array}{l}0.170^{* * *} \\
(0.018)\end{array}$ & $\begin{array}{l}0.172^{* * *} \\
(0.017)\end{array}$ \\
\hline \multicolumn{7}{|l|}{ Income quintiles } \\
\hline Lowest quintile & $\begin{array}{l}0.038^{* *} \\
(0.016)\end{array}$ & $\begin{array}{r}0.025^{*} \\
(0.015)\end{array}$ & $\begin{array}{c}0.011 \\
(0.016)\end{array}$ & $\begin{array}{l}0.030 \\
(0.025)\end{array}$ & $\begin{array}{l}0.117^{* * * *} \\
(0.033)\end{array}$ & $\begin{array}{l}0.122^{* * * *} \\
(0.034)\end{array}$ \\
\hline Second quintile & $\begin{array}{l}0.035^{* *} \\
(0.015)\end{array}$ & $\begin{array}{c}0.008 \\
(0.014)\end{array}$ & $\begin{array}{c}0.018 \\
(0.015)\end{array}$ & $\begin{array}{l}0.055^{* * *} \\
(0.021)\end{array}$ & $\begin{array}{l}0.055^{* * *} \\
(0.021)\end{array}$ & $\begin{array}{l}0.054^{* * * *} \\
(0.021)\end{array}$ \\
\hline Third quintile & $\begin{array}{l}0.030^{* *} \\
(0.013)\end{array}$ & $\begin{array}{c}-0.005 \\
(0.012)\end{array}$ & $\begin{array}{c}0.013 \\
(0.013)\end{array}$ & $\begin{array}{l}0.057^{* * * *} \\
(0.018)\end{array}$ & $\begin{array}{l}0.041^{* *} \\
(0.016)\end{array}$ & $\begin{array}{l}0.042^{* * *} \\
(0.016)\end{array}$ \\
\hline Fourth quintile & $\begin{array}{r}0.024^{*} \\
(0.013)\end{array}$ & $\begin{array}{c}0.023^{*} \\
(0.012)\end{array}$ & $\begin{array}{c}0.002 \\
(0.012)\end{array}$ & $\begin{array}{c}0.019 \\
(0.015)\end{array}$ & $\begin{array}{c}0.012 \\
(0.014)\end{array}$ & $\begin{array}{c}0.012 \\
(0.014)\end{array}$ \\
\hline Female & $\begin{array}{l}0.063^{* * *} \\
(0.009)\end{array}$ & $\begin{array}{l}0.092^{* * *} \\
(0.009)\end{array}$ & $\begin{array}{l}0.093^{* * *} \\
(0.009)\end{array}$ & $\begin{array}{l}0.069^{* * * *} \\
(0.011)\end{array}$ & $\begin{array}{l}0.044^{* * *} \\
(0.013)\end{array}$ & $\begin{array}{l}0.045^{* * *} \\
(0.013)\end{array}$ \\
\hline Child long-term illness & $\begin{array}{c}0.016 \\
(0.012)\end{array}$ & $\begin{array}{c}-0.016 \\
(0.011)\end{array}$ & $\begin{array}{c}-0.006 \\
(0.011)\end{array}$ & $\begin{array}{c}0.004 \\
(0.018)\end{array}$ & $\begin{array}{c}0.006 \\
(0.021)\end{array}$ & $\begin{array}{c}0.007 \\
(0.021)\end{array}$ \\
\hline Health conditions & $\begin{array}{c}0.004 \\
(0.004)\end{array}$ & $\begin{array}{c}0.006 \\
(0.004)\end{array}$ & $\begin{array}{c}0.003 \\
(0.004)\end{array}$ & $\begin{array}{c}0.001 \\
(0.005)\end{array}$ & $\begin{array}{c}0.006 \\
(0.010)\end{array}$ & $\begin{array}{c}0.005 \\
(0.010)\end{array}$ \\
\hline Main parent long-term illness & $\begin{array}{c}-0.015 \\
(0.010)\end{array}$ & $\begin{array}{c}-0.003 \\
(0.010)\end{array}$ & $\begin{array}{c}0.018^{*} \\
(0.010)\end{array}$ & $\begin{array}{c}0.007 \\
(0.013)\end{array}$ & $\begin{array}{c}-0.006 \\
(0.015)\end{array}$ & $\begin{array}{c}-0.003 \\
(0.015)\end{array}$ \\
\hline No. of siblings & $\begin{array}{c}0.003 \\
(0.005)\end{array}$ & $\begin{array}{c}-0.005 \\
(0.004)\end{array}$ & $\begin{array}{l}-0.011^{* *} \\
(0.005)\end{array}$ & $\begin{array}{l}-0.021^{* * *} \\
(0.006)\end{array}$ & $\begin{array}{l}-0.025^{* * *} \\
(0.007)\end{array}$ & $\begin{array}{l}-0.025^{* * *} \\
(0.007)\end{array}$ \\
\hline Birthweight & $\begin{array}{l}0.109^{* * *} \\
(0.009)\end{array}$ & $\begin{array}{l}0.090^{* * * *} \\
(0.008)\end{array}$ & $\begin{array}{l}0.058^{* * *} \\
(0.008)\end{array}$ & $\begin{array}{l}0.033^{* * *} \\
(0.010)\end{array}$ & $\begin{array}{l}0.024^{* *} \\
(0.010)\end{array}$ & $\begin{array}{l}0.028^{* * *} \\
(0.010)\end{array}$ \\
\hline Weight gain 9 months $-3(\mathrm{~kg})$ & $\begin{array}{l}0.077^{* * *} \\
(0.005)\end{array}$ & $\begin{array}{l}0.068^{* * * *} \\
(0.004)\end{array}$ & $\begin{array}{l}0.041^{* * *} \\
(0.004)\end{array}$ & $\begin{array}{l}0.035^{* * *} \\
(0.005)\end{array}$ & $\begin{array}{l}0.023^{* * *} \\
(0.007)\end{array}$ & $\begin{array}{l}0.022^{* * *} \\
(0.007)\end{array}$ \\
\hline \multicolumn{7}{|l|}{ Main Parent's education } \\
\hline NVQ level 1 & $\begin{array}{c}0.008 \\
(0.021)\end{array}$ & $\begin{array}{c}0.019 \\
(0.020)\end{array}$ & $\begin{array}{c}-0.030 \\
(0.020)\end{array}$ & $\begin{array}{c}-0.016 \\
(0.027)\end{array}$ & $\begin{array}{c}-0.009 \\
(0.033)\end{array}$ & $\begin{array}{c}-0.014 \\
(0.034)\end{array}$ \\
\hline NVQ level 2 & $\begin{array}{c}-0.004 \\
(0.017)\end{array}$ & $\begin{array}{c}-0.007 \\
(0.015)\end{array}$ & $\begin{array}{c}-0.007 \\
(0.016)\end{array}$ & $\begin{array}{c}-0.006 \\
(0.022)\end{array}$ & $\begin{array}{c}-0.003 \\
(0.024)\end{array}$ & $\begin{array}{c}-0.006 \\
(0.024)\end{array}$ \\
\hline NVQ level 3 & $\begin{array}{c}-0.004 \\
(0.019)\end{array}$ & $\begin{array}{c}-0.000 \\
(0.017)\end{array}$ & $\begin{array}{r}-0.032^{*} \\
(0.018)\end{array}$ & $\begin{array}{c}-0.025 \\
(0.024)\end{array}$ & $\begin{array}{c}-0.025 \\
(0.026)\end{array}$ & $\begin{array}{c}-0.030 \\
(0.026)\end{array}$ \\
\hline NVQ level 4 & $\begin{array}{c}0.001 \\
(0.018)\end{array}$ & $\begin{array}{c}0.004 \\
(0.016)\end{array}$ & $\begin{array}{c}-0.021 \\
(0.017)\end{array}$ & $\begin{array}{c}-0.016 \\
(0.024)\end{array}$ & $\begin{array}{c}-0.006 \\
(0.025)\end{array}$ & $\begin{array}{c}-0.011 \\
(0.025)\end{array}$ \\
\hline NVQ level 5 & $\begin{array}{l}0.071^{* *} \\
(0.030)\end{array}$ & $\begin{array}{c}0.004 \\
(0.025)\end{array}$ & $\begin{array}{c}-0.026 \\
(0.026)\end{array}$ & $\begin{array}{c}-0.024 \\
(0.035)\end{array}$ & $\begin{array}{c}-0.054 \\
(0.032)\end{array}$ & $\begin{array}{r}-0.058^{*} \\
(0.033)\end{array}$ \\
\hline \multicolumn{7}{|l|}{ Ethnicity } \\
\hline Mixed & $\begin{array}{c}0.032 \\
(0.052)\end{array}$ & $\begin{array}{c}-0.009 \\
(0.040)\end{array}$ & $\begin{array}{c}-0.055 \\
(0.034)\end{array}$ & $\begin{array}{c}0.049 \\
(0.038)\end{array}$ & $\begin{array}{c}-0.030 \\
(0.052)\end{array}$ & $\begin{array}{c}-0.035 \\
(0.049)\end{array}$ \\
\hline Indian & $\begin{array}{c}-0.089^{* * * *} \\
(0.026)\end{array}$ & $\begin{array}{c}0.017 \\
(0.038)\end{array}$ & $\begin{array}{c}0.047 \\
(0.037)\end{array}$ & $\begin{array}{c}0.059 \\
(0.041)\end{array}$ & $\begin{array}{c}0.094 \\
(0.091)\end{array}$ & $\begin{array}{c}0.098 \\
(0.096)\end{array}$ \\
\hline Pakistani and Bangladeshi & $\begin{array}{c}-0.021 \\
(0.023)\end{array}$ & $\begin{array}{c}-0.012 \\
(0.023)\end{array}$ & $\begin{array}{c}-0.000 \\
(0.024)\end{array}$ & $\begin{array}{c}0.065^{* *} \\
(0.033)\end{array}$ & $\begin{array}{c}-0.001 \\
(0.030)\end{array}$ & $\begin{array}{c}-0.004 \\
(0.029)\end{array}$ \\
\hline Black or Black British & $\begin{array}{c}0.014 \\
(0.032)\end{array}$ & $\begin{array}{l}0.062^{* *} \\
(0.031)\end{array}$ & $\begin{array}{c}0.073^{* *} \\
(0.035)\end{array}$ & $\begin{array}{l}0.110^{* * *} \\
(0.041)\end{array}$ & $\begin{array}{c}0.043 \\
(0.037)\end{array}$ & $\begin{array}{c}0.041 \\
(0.038)\end{array}$ \\
\hline Other Ethnic group (inc Chinese, Other) & $\begin{array}{c}-0.013 \\
(0.040)\end{array}$ & $\begin{array}{c}-0.042 \\
(0.032)\end{array}$ & $\begin{array}{c}-0.020 \\
(0.038)\end{array}$ & $\begin{array}{c}0.001 \\
(0.063)\end{array}$ & $\begin{array}{c}0.061 \\
(0.072)\end{array}$ & $\begin{array}{c}0.054 \\
(0.071)\end{array}$ \\
\hline $\mathbb{E}[\operatorname{Pr}($ overweight $) \mid x]$ & 0.161 & 0.133 & 0.124 & 0.198 & 0.155 & 0.156 \\
\hline $\mathrm{N}$ & 10,143 & 10,485 & 9,405 & 7,887 & 6,674 & 6,674 \\
\hline
\end{tabular}

Note: $*$, ** and $* * *$ denote statistical significance it $10 \%, 5 \%$ and $1 \%$ respectively. The outcome in each column is whether a child is overweight, defined using using the the IOTF cutoffs (Table A1). The effects reported are marginal effects obtained after estimating Equation 2 fixing the independent variables at their sample mean. The MCS data do not contain parents' BMI at age 14, so columns 5 and 6 use BMI from age 11 or as predicted to define obesity. All observations are adjusted for the probability of attrition and being sampled, see (Hansen et al., 2014). The omitted categories are income: highest quintile; parents' education: no qualifications; ethnicity: white. Female is an indicator of whether a child is female. $\mathbb{E}[\operatorname{Pr}($ over weight $) \mid \boldsymbol{x}]$ represents the estimated conditional probability a child is overweight at each age. The main parent is the mother for over $99 \%$ of children at 9 months. Ns differ across columns because of missing data. 
Table B3: The determinants of child obesity across childhood with controls

\begin{tabular}{|c|c|c|c|c|c|c|}
\hline & & & & & \multicolumn{2}{|c|}{ (5)-(6) Age 14} \\
\hline & $\begin{array}{c}\text { (1) } \\
\text { Age } 3\end{array}$ & $\begin{array}{c}\text { (2) } \\
\text { Age } 5\end{array}$ & $\begin{array}{c}\text { (3) } \\
\text { Age } 7\end{array}$ & $\begin{array}{c}(4) \\
\text { Age } 11\end{array}$ & $\begin{array}{l}\text { Parental weight } \\
\text { constant }\end{array}$ & $\begin{array}{l}\text { Parental weight } \\
\text { predicted }\end{array}$ \\
\hline Main parent overweight & $\begin{array}{l}0.021^{* * *} \\
(0.006)\end{array}$ & $\begin{array}{l}0.026^{* * *} \\
(0.006)\end{array}$ & $\begin{array}{l}0.035^{* * *} \\
(0.006)\end{array}$ & $\begin{array}{l}0.037^{* * *} \\
(0.007)\end{array}$ & $\begin{array}{l}0.026^{* * *} \\
(0.007)\end{array}$ & $\begin{array}{l}0.025^{* * *} \\
(0.006)\end{array}$ \\
\hline Main parent obese/morbidly obese & $\begin{array}{l}0.048^{* * *} \\
(0.009)\end{array}$ & $\begin{array}{l}0.065^{* * *} \\
(0.008)\end{array}$ & $\begin{array}{l}0.087^{* * *} \\
(0.009)\end{array}$ & $\begin{array}{l}0.084^{* * *} \\
(0.010)\end{array}$ & $\begin{array}{l}0.104^{* * *} \\
(0.011)\end{array}$ & $\begin{array}{l}0.098^{* * *} \\
(0.010)\end{array}$ \\
\hline \multicolumn{7}{|l|}{ Income quintiles } \\
\hline Lowest quintile & $\begin{array}{l}0.020^{* *} \\
(0.009)\end{array}$ & $\begin{array}{r}0.018^{*} \\
(0.009)\end{array}$ & $\begin{array}{c}0.017^{*} \\
(0.010)\end{array}$ & $\begin{array}{l}0.039^{* * * *} \\
(0.014)\end{array}$ & $\begin{array}{l}0.081^{* * *} \\
(0.020)\end{array}$ & $\begin{array}{l}0.082^{* * *} \\
(0.020)\end{array}$ \\
\hline Second quintile & $\begin{array}{c}0.013 \\
(0.008)\end{array}$ & $\begin{array}{c}0.012 \\
(0.008)\end{array}$ & $\begin{array}{c}0.012 \\
(0.008)\end{array}$ & $\begin{array}{l}0.042^{* * *} \\
(0.012)\end{array}$ & $\begin{array}{l}0.033^{* * *} \\
(0.011)\end{array}$ & $\begin{array}{l}0.034^{* * *} \\
(0.012)\end{array}$ \\
\hline Third quintile & $\begin{array}{c}0.003 \\
(0.007)\end{array}$ & $\begin{array}{c}0.007 \\
(0.008)\end{array}$ & $\begin{array}{c}0.007 \\
(0.008)\end{array}$ & $\begin{array}{c}0.022^{* *} \\
(0.010)\end{array}$ & $\begin{array}{c}0.019^{* *} \\
(0.009)\end{array}$ & $\begin{array}{l}0.020^{* *} \\
(0.009)\end{array}$ \\
\hline Fourth quintile & $\begin{array}{c}0.015^{*} \\
(0.007)\end{array}$ & $\begin{array}{c}0.007 \\
(0.008)\end{array}$ & $\begin{array}{c}0.006 \\
(0.008)\end{array}$ & $\begin{array}{c}0.010 \\
(0.008)\end{array}$ & $\begin{array}{c}0.011 \\
(0.008)\end{array}$ & $\begin{array}{c}0.010 \\
(0.008)\end{array}$ \\
\hline Female & $\begin{array}{l}0.023^{* * *} \\
(0.005)\end{array}$ & $\begin{array}{l}0.017^{* * *} \\
(0.005)\end{array}$ & $\begin{array}{l}0.028^{* * *} \\
(0.005)\end{array}$ & $\begin{array}{l}0.023^{* * *} \\
(0.007)\end{array}$ & $\begin{array}{l}0.025^{* * *} \\
(0.007)\end{array}$ & $\begin{array}{l}0.025^{* * *} \\
(0.007)\end{array}$ \\
\hline Child long-term illness & $\begin{array}{r}-0.012^{*} \\
(0.006)\end{array}$ & $\begin{array}{c}0.017^{* *} \\
(0.007)\end{array}$ & $\begin{array}{c}0.003 \\
(0.007)\end{array}$ & $\begin{array}{c}0.003 \\
(0.009)\end{array}$ & $\begin{array}{c}0.009 \\
(0.012)\end{array}$ & $\begin{array}{c}0.010 \\
(0.012)\end{array}$ \\
\hline Health conditions & $\begin{array}{c}0.002 \\
(0.002)\end{array}$ & $\begin{array}{c}0.001 \\
(0.002)\end{array}$ & $\begin{array}{l}0.005^{* *} \\
(0.002)\end{array}$ & $\begin{array}{l}0.005^{* *} \\
(0.002)\end{array}$ & $\begin{array}{l}0.005 \\
(0.004)\end{array}$ & $\begin{array}{c}0.004 \\
(0.005)\end{array}$ \\
\hline Main parent long-term illness & $\begin{array}{c}-0.001 \\
(0.006)\end{array}$ & $\begin{array}{r}0.010^{*} \\
(0.006)\end{array}$ & $\begin{array}{c}0.006 \\
(0.006)\end{array}$ & $\begin{array}{c}0.016^{* *} \\
(0.008)\end{array}$ & $\begin{array}{c}0.009 \\
(0.008)\end{array}$ & $\begin{array}{c}0.010 \\
(0.009)\end{array}$ \\
\hline No. of siblings & $\begin{array}{c}0.000 \\
(0.002)\end{array}$ & $\begin{array}{c}-0.007^{* * *} \\
(0.002)\end{array}$ & $\begin{array}{c}-0.006^{* *} \\
(0.003)\end{array}$ & $\begin{array}{c}-0.010^{* * *} \\
(0.004)\end{array}$ & $\begin{array}{c}-0.010^{* * *} \\
(0.004)\end{array}$ & $\begin{array}{c}-0.010^{* * *} \\
(0.004)\end{array}$ \\
\hline Birthweight & $\begin{array}{l}0.014^{* * *} \\
(0.005)\end{array}$ & $\begin{array}{l}0.026^{* * *} \\
(0.005)\end{array}$ & $\begin{array}{l}0.012^{* * *} \\
(0.005)\end{array}$ & $\begin{array}{l}0.020^{* * *} \\
(0.005)\end{array}$ & $\begin{array}{l}0.027^{* * *} \\
(0.006)\end{array}$ & $\begin{array}{l}0.028^{* * *} \\
(0.006)\end{array}$ \\
\hline Weight gain 9 months-3 (kg) & $\begin{array}{l}0.024^{* * * *} \\
(0.002)\end{array}$ & $\begin{array}{l}0.018^{* * *} \\
(0.002)\end{array}$ & $\begin{array}{l}0.017^{* * *} \\
(0.002)\end{array}$ & $\begin{array}{l}0.014^{* * *} \\
(0.003)\end{array}$ & $\begin{array}{l}0.012^{* * *} \\
(0.003)\end{array}$ & $\begin{array}{l}0.012^{* * *} \\
(0.003)\end{array}$ \\
\hline \multicolumn{7}{|l|}{ Main Parent's education } \\
\hline NVQ level 1 & $\begin{array}{c}0.007 \\
(0.012)\end{array}$ & $\begin{array}{c}-0.003 \\
(0.012)\end{array}$ & $\begin{array}{c}0.001 \\
(0.012)\end{array}$ & $\begin{array}{c}0.006 \\
(0.016)\end{array}$ & $\begin{array}{c}0.014 \\
(0.015)\end{array}$ & $\begin{array}{c}0.013 \\
(0.016)\end{array}$ \\
\hline NVQ level 2 & $\begin{array}{r}-0.010 \\
(0.009)\end{array}$ & $\begin{array}{c}-0.007 \\
(0.009)\end{array}$ & $\begin{array}{c}0.004 \\
(0.009)\end{array}$ & $\begin{array}{c}-0.017 \\
(0.012)\end{array}$ & $\begin{array}{c}0.011 \\
(0.012)\end{array}$ & $\begin{array}{c}0.010 \\
(0.012)\end{array}$ \\
\hline NVQ level 3 & $\begin{array}{c}-0.014 \\
(0.010)\end{array}$ & $\begin{array}{c}-0.024^{* *} \\
(0.010)\end{array}$ & $\begin{array}{c}0.001 \\
(0.011)\end{array}$ & $\begin{array}{c}-0.035^{* * *} \\
(0.012)\end{array}$ & $\begin{array}{c}0.007 \\
(0.014)\end{array}$ & $\begin{array}{c}0.006 \\
(0.014)\end{array}$ \\
\hline NVQ level 4 & $\begin{array}{c}-0.008 \\
(0.009)\end{array}$ & $\begin{array}{c}-0.024^{* * *} \\
(0.009)\end{array}$ & $\begin{array}{c}-0.013 \\
(0.009)\end{array}$ & $\begin{array}{r}-0.025^{*} \\
(0.013)\end{array}$ & $\begin{array}{c}-0.007 \\
(0.012)\end{array}$ & $\begin{array}{c}-0.008 \\
(0.012)\end{array}$ \\
\hline NVQ level 5 & $\begin{array}{c}0.006 \\
(0.018)\end{array}$ & $\begin{array}{c}-0.035^{* *} \\
(0.013)\end{array}$ & $\begin{array}{c}-0.034^{* *} \\
(0.012)\end{array}$ & $\begin{array}{c}-0.054^{* * *} \\
(0.016)\end{array}$ & $\begin{array}{c}-0.015 \\
(0.018)\end{array}$ & $\begin{array}{c}-0.016 \\
(0.018)\end{array}$ \\
\hline \multicolumn{7}{|l|}{ Ethnicity } \\
\hline Mixed & $\begin{array}{l}0.047^{* *} \\
(0.030)\end{array}$ & $\begin{array}{c}0.009 \\
(0.023)\end{array}$ & $\begin{array}{c}-0.030 \\
(0.018)\end{array}$ & $\begin{array}{r}0.037^{*} \\
(0.023)\end{array}$ & $\begin{array}{c}-0.008 \\
(0.032)\end{array}$ & $\begin{array}{r}-0.008 \\
(0.032)\end{array}$ \\
\hline Indian & $\begin{array}{c}-0.002 \\
(0.020)\end{array}$ & $\begin{array}{c}0.017 \\
(0.025)\end{array}$ & $\begin{array}{c}0.036 \\
(0.028)\end{array}$ & $\begin{array}{r}-0.032^{*} \\
(0.012)\end{array}$ & $\begin{array}{c}-0.011 \\
(0.021)\end{array}$ & $\begin{array}{c}-0.011 \\
(0.021)\end{array}$ \\
\hline Pakistani and Bangladeshi & $\begin{array}{c}0.004 \\
(0.011)\end{array}$ & $\begin{array}{l}0.039^{* * * *} \\
(0.016)\end{array}$ & $\begin{array}{c}0.027^{* *} \\
(0.016)\end{array}$ & $\begin{array}{c}0.028 \\
(0.020)\end{array}$ & $\begin{array}{c}0.008 \\
(0.017)\end{array}$ & $\begin{array}{c}0.008 \\
(0.017)\end{array}$ \\
\hline Black or Black British & $\begin{array}{l}0.049^{* * *} \\
(0.020)\end{array}$ & $\begin{array}{l}0.059^{* * *} \\
(0.022)\end{array}$ & $\begin{array}{l}0.081^{* * * *} \\
(0.022)\end{array}$ & $\begin{array}{c}0.043^{* *} \\
(0.023)\end{array}$ & $\begin{array}{c}0.016 \\
(0.021)\end{array}$ & $\begin{array}{c}0.017 \\
(0.021)\end{array}$ \\
\hline Other Ethnic group (inc Chinese,Other) & $\begin{array}{c}0.019 \\
(0.026)\end{array}$ & $\begin{array}{c}0.018 \\
(0.028)\end{array}$ & $\begin{array}{c}0.026 \\
(0.032)\end{array}$ & $\begin{array}{c}-0.001 \\
(0.028)\end{array}$ & $\begin{array}{c}-0.010 \\
(0.023)\end{array}$ & $\begin{array}{c}-0.012 \\
(0.023)\end{array}$ \\
\hline $\mathbb{E}[\operatorname{Pr}($ obese $) \mid x]$ & 0.038 & 0.039 & 0.042 & 0.043 & 0.039 & 0.039 \\
\hline $\mathrm{N}$ & 10,714 & 11,119 & 10,186 & 8,426 & 7,067 & 7,067 \\
\hline
\end{tabular}

Note: $*, * *$ and $* * *$ denote statistical significance it $10 \%, 5 \%$ and $1 \%$ respectively. The outcome in each column is whether a child is obese, defined using using the the IOTF cutoffs (Table A1). The effects reported are marginal effects obtained after estimating Equation 2 fixing the independent variables at their sample mean. The MCS data do not contain parents' BMI at age 14, so columns 5 and 6 use BMI from age 11 or as predicted to define obesity. All observations are adjusted for the probability of attrition and being sampled, see (Hansen et al., 2014). The omitted categories are income: highest quintile; parents' education: no qualifications; ethnicity: white. Female is an indicator of whether a child is female. $\mathbb{E}[\operatorname{Pr}($ obese $) \mid x]$ represents the estimated conditional probability a child is obese at each age. The main parent is the mother for over $99 \%$ of children at 9 months. Ns differ across columns because of missing data. 
Table B4: The determinants of child overweight or obesity across childhood with controls

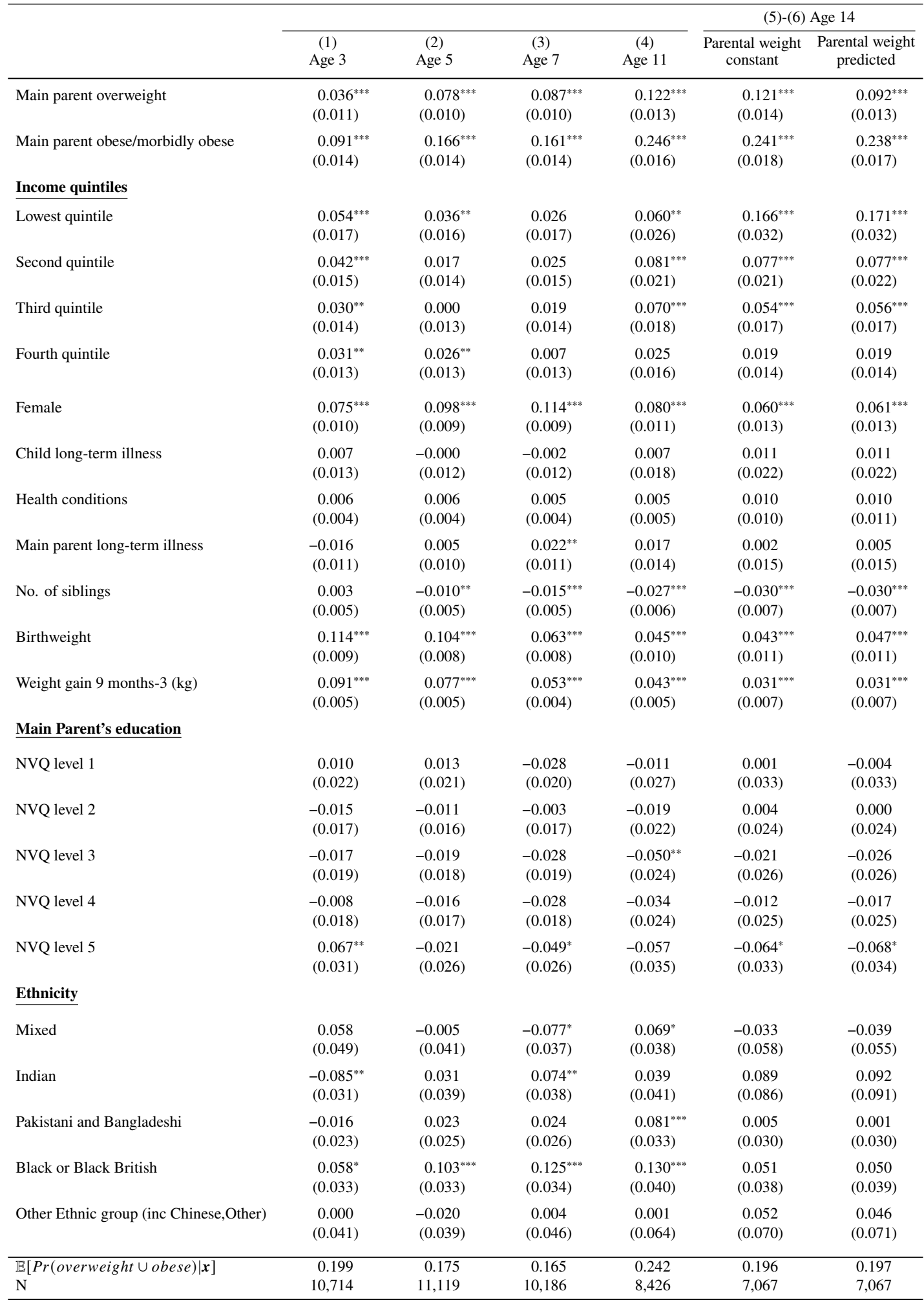

Note: $* * *$ and $* * *$ denote statistical significance it $10 \%, 5 \%$ and $1 \%$ respectively. The outcome in each column is whether a child is overweight or obese, defined using using the the IOTF cutoffs (Table A1). The effects reported are marginal effects obtained after estimating Equation 2 fixing the independent variables at their sample mean. The MCS data do not contain parents' BMI at age 14, so columns 5 and 6 use BMI from age 11 or as predicted to define obesity. All observations are adjusted for the probability of attrition and being sampled, see (Hansen et al., 2014). The omitted categories are income: highest quintile; parents' education: no qualifications; ethnicity: white. Female is an indicator of whether a child is female. $\mathbb{E}[\operatorname{Pr}($ overweight $\cup$ obese $) \mid x]$ represents the estimated conditional probability a child is overweight or ebeseat each age. The main parent is the mother for over $99 \%$ of children at 9 months. Ns differ across columns because of missing data. 
Table B5: The determinants of child overweight across childhood fixing income and parents' weight at their level when child was 9 months old

\begin{tabular}{|c|c|c|c|c|c|c|}
\hline & & & & & \multicolumn{2}{|c|}{ (5)-(6) Age 14} \\
\hline & $\begin{array}{c}\text { (1) } \\
\text { Age } 3\end{array}$ & $\begin{array}{c}(2) \\
\text { Age } 5\end{array}$ & $\begin{array}{c}\text { (3) } \\
\text { Age } 7\end{array}$ & $\begin{array}{c}(4) \\
\text { Age } 11\end{array}$ & $\begin{array}{l}\text { Parental weight } \\
\text { constant }\end{array}$ & $\begin{array}{l}\text { Parental weight } \\
\text { predicted }\end{array}$ \\
\hline \multicolumn{7}{|l|}{ Main parent weight category at 9 months } \\
\hline Overweight & $\begin{array}{l}0.045^{* * * *} \\
(0.012)\end{array}$ & $\begin{array}{l}0.074^{* * * *} \\
(0.011)\end{array}$ & $\begin{array}{l}0.073^{* * * *} \\
(0.012)\end{array}$ & $\begin{array}{l}0.132^{* * *} \\
(0.015)\end{array}$ & $\begin{array}{l}0.110^{* * * *} \\
(0.016)\end{array}$ & $\begin{array}{l}0.116^{* * *} \\
(0.016)\end{array}$ \\
\hline Obese/Morbidly obese & $\begin{array}{l}0.071^{* * * *} \\
(0.016)\end{array}$ & $\begin{array}{l}0.139^{* * * *} \\
(0.017)\end{array}$ & $\begin{array}{l}0.116^{* * * *} \\
(0.018)\end{array}$ & $\begin{array}{l}0.255^{* * * *} \\
(0.024)\end{array}$ & $\begin{array}{l}0.230^{* * * *} \\
(0.026)\end{array}$ & $\begin{array}{l}0.240^{* * * *} \\
(0.028)\end{array}$ \\
\hline \multicolumn{7}{|l|}{ Current weight } \\
\hline Moved to lighter category & $\begin{array}{c}0.020 \\
(0.018)\end{array}$ & $\begin{array}{l}-0.008 \\
(0.014)\end{array}$ & $\begin{array}{c}0.011 \\
(0.016)\end{array}$ & $\begin{array}{c}-0.026 \\
(0.020)\end{array}$ & $\begin{array}{l}-0.015 \\
(0.020)\end{array}$ & $\begin{array}{l}-0.026 \\
(0.023)\end{array}$ \\
\hline Moved to heavier category & $\begin{array}{c}0.022 \\
(0.015)\end{array}$ & $\begin{array}{l}0.045^{* * *} \\
(0.013)\end{array}$ & $\begin{array}{l}0.040^{* * * *} \\
(0.013)\end{array}$ & $\begin{array}{l}0.061^{* * * *} \\
(0.014)\end{array}$ & $\begin{array}{l}0.078^{* * * *} \\
(0.017)\end{array}$ & $\begin{array}{l}0.060^{* * *} \\
(0.014)\end{array}$ \\
\hline \multicolumn{7}{|l|}{ Income quintiles at 9 months } \\
\hline Lowest quintile & $\begin{array}{l}0.055^{* * * *} \\
(0.019)\end{array}$ & $\begin{array}{l}0.045^{* * *} \\
(0.017)\end{array}$ & $\begin{array}{l}0.050^{* * * *} \\
(0.018)\end{array}$ & $\begin{array}{l}0.094^{* * * *} \\
(0.025)\end{array}$ & $\begin{array}{l}0.114^{* * * *} \\
(0.029)\end{array}$ & $\begin{array}{l}0.116^{* * * *} \\
(0.029)\end{array}$ \\
\hline Second quintile & $\begin{array}{l}0.033^{* *} \\
(0.016)\end{array}$ & $\begin{array}{l}0.032^{* *} \\
(0.015)\end{array}$ & $\begin{array}{l}0.049^{* * * *} \\
(0.015)\end{array}$ & $\begin{array}{l}0.073^{* * * *} \\
(0.021)\end{array}$ & $\begin{array}{l}0.069^{* * *} \\
(0.021)\end{array}$ & $\begin{array}{l}0.069^{* * * *} \\
(0.021)\end{array}$ \\
\hline Third quintile & $\begin{array}{c}0.015 \\
(0.014)\end{array}$ & $\begin{array}{r}0.025^{*} \\
(0.013)\end{array}$ & $\begin{array}{l}0.047^{* * * *} \\
(0.014)\end{array}$ & $\begin{array}{l}0.066^{* * * *} \\
(0.018)\end{array}$ & $\begin{array}{l}0.076^{* * *} \\
(0.019)\end{array}$ & $\begin{array}{l}0.077^{* * * *} \\
(0.019)\end{array}$ \\
\hline Fourth quintile & $\begin{array}{c}0.019 \\
(0.014)\end{array}$ & $\begin{array}{l}0.030^{* *} \\
(0.013)\end{array}$ & $\begin{array}{l}0.034^{* * *} \\
(0.012)\end{array}$ & $\begin{array}{l}0.048^{* * * *} \\
(0.016)\end{array}$ & $\begin{array}{l}0.043^{* * *} \\
(0.015)\end{array}$ & $\begin{array}{l}0.043^{\text {**** }} \\
(0.015)\end{array}$ \\
\hline \multicolumn{7}{|l|}{ Current income quintile } \\
\hline Moved down & $\begin{array}{c}-0.009 \\
(0.012)\end{array}$ & $\begin{array}{l}-0.009 \\
(0.011)\end{array}$ & $\begin{array}{c}0.013 \\
(0.011)\end{array}$ & $\begin{array}{c}-0.006 \\
(0.016)\end{array}$ & $\begin{array}{c}0.003 \\
(0.018)\end{array}$ & $\begin{array}{c}0.004 \\
(0.018)\end{array}$ \\
\hline Moved up & $\begin{array}{r}-0.019^{*} \\
(0.011)\end{array}$ & $\begin{array}{l}-0.015 \\
(0.010)\end{array}$ & $\begin{array}{c}0.015 \\
(0.011)\end{array}$ & $\begin{array}{l}-0.008 \\
(0.014)\end{array}$ & $\begin{array}{l}-0.041^{\text {**** }} \\
(0.016)\end{array}$ & $\begin{array}{l}-0.041^{* * * *} \\
(0.016)\end{array}$ \\
\hline Female & $\begin{array}{l}0.062^{\text {**** }} \\
(0.010)\end{array}$ & $\begin{array}{l}0.090^{* * *} \\
(0.009)\end{array}$ & $\begin{array}{l}0.091^{* * * *} \\
(0.009)\end{array}$ & $\begin{array}{l}0.070^{* * * *} \\
(0.012)\end{array}$ & $\begin{array}{l}0.043^{* * * *} \\
(0.014)\end{array}$ & $\begin{array}{l}0.043^{* * * *} \\
(0.014)\end{array}$ \\
\hline Child long-term illness & $\begin{array}{c}0.019 \\
(0.013)\end{array}$ & $\begin{array}{c}-0.012 \\
(0.012)\end{array}$ & $\begin{array}{l}-0.011 \\
(0.012)\end{array}$ & $\begin{array}{l}-0.002 \\
(0.018)\end{array}$ & $\begin{array}{l}-0.000 \\
(0.022)\end{array}$ & $\begin{array}{l}-0.000 \\
(0.022)\end{array}$ \\
\hline Health conditions & $\begin{array}{c}0.004 \\
(0.004)\end{array}$ & $\begin{array}{c}0.004 \\
(0.004)\end{array}$ & $\begin{array}{c}0.003 \\
(0.004)\end{array}$ & $\begin{array}{c}0.001 \\
(0.005)\end{array}$ & $\begin{array}{c}0.002 \\
(0.011)\end{array}$ & $\begin{array}{c}0.002 \\
(0.012)\end{array}$ \\
\hline Main parent long-term illness & $\begin{array}{c}-0.015 \\
(0.011)\end{array}$ & $\begin{array}{l}-0.006 \\
(0.010)\end{array}$ & $\begin{array}{c}0.017 \\
(0.011)\end{array}$ & $\begin{array}{c}0.003 \\
(0.014)\end{array}$ & $\begin{array}{c}0.002 \\
(0.016)\end{array}$ & $\begin{array}{c}0.004 \\
(0.016)\end{array}$ \\
\hline No. of siblings & $\begin{array}{l}-0.003 \\
(0.005)\end{array}$ & $\begin{array}{l}-0.008^{*} \\
(0.005)\end{array}$ & $\begin{array}{l}-0.014^{* * *} \\
(0.005)\end{array}$ & $\begin{array}{l}-0.020^{* * * *} \\
(0.007)\end{array}$ & $\begin{array}{l}-0.022^{* * *} \\
(0.007)\end{array}$ & $\begin{array}{l}-0.022^{* * *} \\
(0.007)\end{array}$ \\
\hline Birthweight & $\begin{array}{l}0.110^{* * * *} \\
(0.009)\end{array}$ & $\begin{array}{l}0.087^{* * *} \\
(0.008)\end{array}$ & $\begin{array}{l}0.055^{* * * *} \\
(0.008)\end{array}$ & $\begin{array}{c}0.025^{* *} \\
(0.010)\end{array}$ & $\begin{array}{c}0.023^{* *} \\
(0.011)\end{array}$ & $\begin{array}{l}0.024^{* *} \\
(0.011)\end{array}$ \\
\hline Weight gain 9 months-3 (kg) & $\begin{array}{l}0.077^{* * *} \\
(0.005)\end{array}$ & $\begin{array}{l}0.069^{* * *} \\
(0.005)\end{array}$ & $\begin{array}{l}0.041^{* * * *} \\
(0.005)\end{array}$ & $\begin{array}{l}0.036^{* * *} \\
(0.005)\end{array}$ & $\begin{array}{l}0.022^{* * * *} \\
(0.007)\end{array}$ & $\begin{array}{l}0.021^{* * * *} \\
(0.008)\end{array}$ \\
\hline \multicolumn{7}{|l|}{$\underline{\text { Main Parent's education }}$} \\
\hline NVQ level 1 & $\begin{array}{c}-0.004 \\
(0.023)\end{array}$ & $\begin{array}{c}0.009 \\
(0.021)\end{array}$ & $\begin{array}{l}-0.032 \\
(0.020)\end{array}$ & $\begin{array}{c}-0.011 \\
(0.029)\end{array}$ & $\begin{array}{c}-0.009 \\
(0.037)\end{array}$ & $\begin{array}{c}-0.013 \\
(0.038)\end{array}$ \\
\hline NVQ level 2 & $\begin{array}{c}-0.011 \\
(0.018)\end{array}$ & $\begin{array}{l}-0.016 \\
(0.017)\end{array}$ & $\begin{array}{l}-0.003 \\
(0.017)\end{array}$ & $\begin{array}{c}0.001 \\
(0.023)\end{array}$ & $\begin{array}{c}-0.018 \\
(0.027)\end{array}$ & $\begin{array}{l}-0.020 \\
(0.027)\end{array}$ \\
\hline NVQ level 3 & $\begin{array}{c}-0.011 \\
(0.020)\end{array}$ & $\begin{array}{l}-0.007 \\
(0.019)\end{array}$ & $\begin{array}{c}-0.028 \\
(0.019)\end{array}$ & $\begin{array}{l}-0.018 \\
(0.025)\end{array}$ & $\begin{array}{c}-0.043 \\
(0.028)\end{array}$ & $\begin{array}{c}-0.045^{*} \\
(0.029)\end{array}$ \\
\hline NVQ level 4 & $\begin{array}{l}-0.007 \\
(0.020)\end{array}$ & $\begin{array}{c}-0.002 \\
(0.018)\end{array}$ & $\begin{array}{l}-0.007 \\
(0.019)\end{array}$ & $\begin{array}{l}-0.010 \\
(0.025)\end{array}$ & $\begin{array}{c}-0.017 \\
(0.028)\end{array}$ & $\begin{array}{l}-0.020 \\
(0.028)\end{array}$ \\
\hline NVQ level 5 & $\begin{array}{c}0.047 \\
(0.032)\end{array}$ & $\begin{array}{c}-0.003 \\
(0.028)\end{array}$ & $\begin{array}{l}-0.005 \\
(0.029)\end{array}$ & $\begin{array}{l}-0.031 \\
(0.036)\end{array}$ & $\begin{array}{l}-0.050 \\
(0.037)\end{array}$ & $\begin{array}{l}-0.053 \\
(0.037)\end{array}$ \\
\hline \multicolumn{7}{|l|}{ Ethnicity } \\
\hline Mixed & $\begin{array}{c}0.052 \\
(0.058)\end{array}$ & $\begin{array}{c}0.005 \\
(0.045)\end{array}$ & $\begin{array}{l}-0.038 \\
(0.042)\end{array}$ & $\begin{array}{c}0.056 \\
(0.038)\end{array}$ & $\begin{array}{c}-0.011 \\
(0.059)\end{array}$ & $\begin{array}{c}-0.009 \\
(0.059)\end{array}$ \\
\hline Indian & $\begin{array}{c}-0.094^{* * *} \\
(0.026)\end{array}$ & $\begin{array}{c}0.003 \\
(0.041)\end{array}$ & $\begin{array}{c}0.061 \\
(0.042)\end{array}$ & $\begin{array}{c}0.048 \\
(0.048)\end{array}$ & $\begin{array}{c}0.112 \\
(0.103)\end{array}$ & $\begin{array}{c}0.115 \\
(0.108)\end{array}$ \\
\hline Pakistani and Bangladeshi & $\begin{array}{c}-0.029 \\
(0.025)\end{array}$ & $\begin{array}{l}-0.027 \\
(0.024)\end{array}$ & $\begin{array}{c}0.009 \\
(0.029)\end{array}$ & $\begin{array}{c}0.044 \\
(0.035)\end{array}$ & $\begin{array}{l}-0.017 \\
(0.030)\end{array}$ & $\begin{array}{l}-0.017 \\
(0.030)\end{array}$ \\
\hline Black or Black British & $\begin{array}{c}0.030 \\
(0.035)\end{array}$ & $\begin{array}{c}0.063^{* *} \\
(0.033)\end{array}$ & $\begin{array}{c}0.056^{*} \\
(0.036)\end{array}$ & $\begin{array}{l}0.113^{* * * *} \\
(0.045)\end{array}$ & $\begin{array}{c}0.039 \\
(0.039)\end{array}$ & $\begin{array}{c}0.037 \\
(0.039)\end{array}$ \\
\hline Other Ethnic group (inc Chinese, Other) & $\begin{array}{c}-0.011 \\
(0.044)\end{array}$ & $\begin{array}{c}-0.052 \\
(0.033)\end{array}$ & $\begin{array}{l}-0.032 \\
(0.039)\end{array}$ & $\begin{array}{c}0.004 \\
(0.066)\end{array}$ & $\begin{array}{c}0.071 \\
(0.076)\end{array}$ & $\begin{array}{c}0.069 \\
(0.076)\end{array}$ \\
\hline $\begin{array}{l}\mathbb{E}[\operatorname{Pr}(\text { overweight }) \mid x] \\
\mathrm{N}\end{array}$ & $\begin{array}{l}0.159 \\
9,207\end{array}$ & $\begin{array}{l}0.132 \\
9,514\end{array}$ & $\begin{array}{l}0.123 \\
8,566\end{array}$ & $\begin{array}{l}0.195 \\
7,178\end{array}$ & $\begin{array}{l}0.153 \\
6,089\end{array}$ & $\begin{array}{l}0.154 \\
6,089\end{array}$ \\
\hline \multicolumn{7}{|c|}{$\begin{array}{l}\text { Note: *, ** and } * * * \text { denote statistical significance it } 10 \%, 5 \% \text { and } 1 \% \text { respectively. The outcome in each column } \\
\text { is whether a child is overweight, defined using the the IOTF cutoffs (Table A1). The effects reported are marginal } \\
\text { effects obtained after estimating Equation } 2 \text { fixing the independent variables at their sample mean. The MCS } \\
\text { data does not contain parents' BMI at age } 14 \text {, so columns } 5 \text { and } 6 \text { use BMI from age } 11 \text { or as predicted to define } \\
\text { obesity. All observations are adjusted for the probability of attrition and being sampled, see (Hansen et al., 2014). } \\
\text { The omitted categories are income at } 9 \text { months: highest quintile; current income quintile and weight category: } \\
\text { stayed the same; parents' education: no qualifications; ethnicity: white. } \mathbb{E}[\operatorname{Pr}(\text { over weight) } \mid x] \text { represents the } \\
\text { estimated conditional expectation a child is overweight. The main parent is the mother for over } 99 \% \text { of children at } \\
9 \text { months. Ns differ across columns because of missing data. }\end{array}$} \\
\hline
\end{tabular}


Table B6: The determinants of child obesity across childhood fixing income and parents' weight at their level when child was 9 months old

\begin{tabular}{|c|c|c|c|c|c|c|}
\hline & & & & & \multicolumn{2}{|c|}{ (5)-(6) Age 14} \\
\hline & $\begin{array}{c}\text { (1) } \\
\text { Age } 3\end{array}$ & $\begin{array}{c}\text { (2) } \\
\text { Age } 5\end{array}$ & $\begin{array}{c}\text { (3) } \\
\text { Age } 7\end{array}$ & $\begin{array}{c}(4) \\
\text { Age } 11\end{array}$ & $\begin{array}{l}\text { Parental weight } \\
\text { constant }\end{array}$ & $\begin{array}{l}\text { Parental weight } \\
\text { predicted }\end{array}$ \\
\hline \multicolumn{7}{|l|}{ Main parent weight category at 9 months } \\
\hline Overweight & $\begin{array}{l}0.026^{* * *} \\
(0.006)\end{array}$ & $\begin{array}{l}0.026^{* * * *} \\
(0.006)\end{array}$ & $\begin{array}{l}0.045^{* * * *} \\
(0.007)\end{array}$ & $\begin{array}{l}0.050^{* * * *} \\
(0.008)\end{array}$ & $\begin{array}{l}0.044^{* * * *} \\
(0.009)\end{array}$ & $\begin{array}{l}0.045^{* * *} \\
(0.008)\end{array}$ \\
\hline Obese/Morbidly obese & $\begin{array}{l}0.065^{* * * *} \\
(0.011)\end{array}$ & $\begin{array}{l}0.085^{* * *} \\
(0.011)\end{array}$ & $\begin{array}{l}0.114^{* * *} \\
(0.014)\end{array}$ & $\begin{array}{l}0.127^{* * * *} \\
(0.016)\end{array}$ & $\begin{array}{l}0.142^{* * *} \\
(0.019)\end{array}$ & $\begin{array}{l}0.147^{\text {**** }} \\
(0.022)\end{array}$ \\
\hline \multicolumn{7}{|l|}{ Current weight } \\
\hline Moved to lighter category & $\begin{array}{c}0.003 \\
(0.009)\end{array}$ & $\begin{array}{c}-0.005 \\
(0.008)\end{array}$ & $\begin{array}{r}-0.015^{*} \\
(0.007)\end{array}$ & $\begin{array}{l}-0.003 \\
(0.009)\end{array}$ & $\begin{array}{l}-0.014 \\
(0.009)\end{array}$ & $\begin{array}{l}-0.013 \\
(0.011)\end{array}$ \\
\hline Moved to heavier category & $\begin{array}{c}0.012 \\
(0.009)\end{array}$ & $\begin{array}{l}0.034^{* * *} \\
(0.010)\end{array}$ & $\begin{array}{l}0.027^{* * * *} \\
(0.009)\end{array}$ & $\begin{array}{r}0.015^{*} \\
(0.009)\end{array}$ & $\begin{array}{l}0.033^{* * * *} \\
(0.011)\end{array}$ & $\begin{array}{l}0.028^{* * *} \\
(0.010)\end{array}$ \\
\hline \multicolumn{7}{|l|}{ Income quintiles at 9 months } \\
\hline Lowest quintile & $\begin{array}{r}0.015^{*} \\
(0.009)\end{array}$ & $\begin{array}{l}0.022^{* *} \\
(0.011)\end{array}$ & $\begin{array}{l}0.023^{* *} \\
(0.012)\end{array}$ & $\begin{array}{l}0.044^{* * * *} \\
(0.014)\end{array}$ & $\begin{array}{l}0.063^{* * * *} \\
(0.018)\end{array}$ & $\begin{array}{l}0.063^{* * * *} \\
(0.018)\end{array}$ \\
\hline Second quintile & $\begin{array}{l}0.019^{* *} \\
(0.009)\end{array}$ & $\begin{array}{c}0.006 \\
(0.009)\end{array}$ & $\begin{array}{r}0.018^{*} \\
(0.010)\end{array}$ & $\begin{array}{l}0.038^{* * * *} \\
(0.011)\end{array}$ & $\begin{array}{l}0.040^{* * * *} \\
(0.012)\end{array}$ & $\begin{array}{l}0.040^{* * *} \\
(0.012)\end{array}$ \\
\hline Third quintile & $\begin{array}{l}0.018^{* *} \\
(0.007)\end{array}$ & $\begin{array}{c}0.001 \\
(0.008)\end{array}$ & $\begin{array}{c}0.001 \\
(0.008)\end{array}$ & $\begin{array}{l}0.020^{* *} \\
(0.009)\end{array}$ & $\begin{array}{c}0.011 \\
(0.009)\end{array}$ & $\begin{array}{c}0.011 \\
(0.009)\end{array}$ \\
\hline Fourth quintile & $\begin{array}{l}0.021^{* * * *} \\
(0.008)\end{array}$ & $\begin{array}{c}0.009 \\
(0.008)\end{array}$ & $\begin{array}{c}0.005 \\
(0.008)\end{array}$ & $\begin{array}{l}0.018^{* *} \\
(0.008)\end{array}$ & $\begin{array}{c}0.004 \\
(0.008)\end{array}$ & $\begin{array}{c}0.004 \\
(0.008)\end{array}$ \\
\hline \multicolumn{7}{|l|}{ Current income quintile } \\
\hline Moved down & $\begin{array}{l}-0.000 \\
(0.007)\end{array}$ & $\begin{array}{c}0.007 \\
(0.007)\end{array}$ & $\begin{array}{l}-0.004 \\
(0.007)\end{array}$ & $\begin{array}{c}0.000 \\
(0.009)\end{array}$ & $\begin{array}{c}0.012 \\
(0.011)\end{array}$ & $\begin{array}{c}0.012 \\
(0.011)\end{array}$ \\
\hline Moved up & $\begin{array}{c}0.001 \\
(0.006)\end{array}$ & $\begin{array}{c}0.001 \\
(0.006)\end{array}$ & $\begin{array}{l}-0.006 \\
(0.007)\end{array}$ & $\begin{array}{l}-0.016^{* *} \\
(0.007)\end{array}$ & $\begin{array}{l}-0.005 \\
(0.009)\end{array}$ & $\begin{array}{l}-0.005 \\
(0.009)\end{array}$ \\
\hline Female & $\begin{array}{l}0.025^{* * * *} \\
(0.006)\end{array}$ & $\begin{array}{l}0.019^{* * *} \\
(0.005)\end{array}$ & $\begin{array}{l}0.028^{* * * *} \\
(0.006)\end{array}$ & $\begin{array}{l}0.021^{* * * *} \\
(0.007)\end{array}$ & $\begin{array}{l}0.022^{* * *} \\
(0.007)\end{array}$ & $\begin{array}{l}0.022^{* * * *} \\
(0.007)\end{array}$ \\
\hline Child long-term illness & $\begin{array}{c}-0.010 \\
(0.006)\end{array}$ & $\begin{array}{l}0.016^{* *} \\
(0.007)\end{array}$ & $\begin{array}{c}0.001 \\
(0.007)\end{array}$ & $\begin{array}{c}0.007 \\
(0.010)\end{array}$ & $\begin{array}{c}0.007 \\
(0.012)\end{array}$ & $\begin{array}{c}0.006 \\
(0.012)\end{array}$ \\
\hline Health conditions & $\begin{array}{c}0.002 \\
(0.002)\end{array}$ & $\begin{array}{c}0.001 \\
(0.002)\end{array}$ & $\begin{array}{c}0.004 \\
(0.002)\end{array}$ & $\begin{array}{c}0.003 \\
(0.002)\end{array}$ & $\begin{array}{c}0.003 \\
(0.005)\end{array}$ & $\begin{array}{c}0.003 \\
(0.005)\end{array}$ \\
\hline Main parent long-term illness & $\begin{array}{c}-0.001 \\
(0.006)\end{array}$ & $\begin{array}{c}0.012^{*} \\
(0.006)\end{array}$ & $\begin{array}{c}0.004 \\
(0.006)\end{array}$ & $\begin{array}{r}0.012^{*} \\
(0.008)\end{array}$ & $\begin{array}{c}0.010 \\
(0.009)\end{array}$ & $\begin{array}{c}0.011 \\
(0.009)\end{array}$ \\
\hline No. of siblings & $\begin{array}{c}0.001 \\
(0.003)\end{array}$ & $\begin{array}{l}-0.008^{* * * *} \\
(0.002)\end{array}$ & $\begin{array}{c}-0.007^{\text {*** }} \\
(0.003)\end{array}$ & $\begin{array}{l}-0.012^{\text {**** }} \\
(0.004)\end{array}$ & $\begin{array}{c}-0.004 \\
(0.004)\end{array}$ & $\begin{array}{l}-0.004 \\
(0.004)\end{array}$ \\
\hline Birthweight & $\begin{array}{l}0.010^{* *} \\
(0.005)\end{array}$ & $\begin{array}{l}0.024^{* * * *} \\
(0.005)\end{array}$ & $\begin{array}{c}0.009^{*} \\
(0.005)\end{array}$ & $\begin{array}{l}0.016^{* * * *} \\
(0.006)\end{array}$ & $\begin{array}{l}0.026^{* * *} \\
(0.006)\end{array}$ & $\begin{array}{l}0.027^{* * *} \\
(0.006)\end{array}$ \\
\hline Weight gain 9 months-3 $(\mathrm{kg})$ & $\begin{array}{l}0.024^{* * * *} \\
(0.003)\end{array}$ & $\begin{array}{l}0.018^{* * *} \\
(0.002)\end{array}$ & $\begin{array}{l}0.017^{* * * *} \\
(0.002)\end{array}$ & $\begin{array}{l}0.014^{* * * *} \\
(0.003)\end{array}$ & $\begin{array}{l}0.014^{* * * *} \\
(0.003)\end{array}$ & $\begin{array}{l}0.014^{\text {**** }} \\
(0.003)\end{array}$ \\
\hline \multicolumn{7}{|l|}{ Main Parent's education } \\
\hline NVQ level 1 & $\begin{array}{c}-0.003 \\
(0.013)\end{array}$ & $\begin{array}{c}0.004 \\
(0.012)\end{array}$ & $\begin{array}{c}0.003 \\
(0.012)\end{array}$ & $\begin{array}{c}0.015 \\
(0.017)\end{array}$ & $\begin{array}{c}0.012 \\
(0.016)\end{array}$ & $\begin{array}{c}0.011 \\
(0.016)\end{array}$ \\
\hline NVQ level 2 & $\begin{array}{r}-0.017^{*} \\
(0.010)\end{array}$ & $\begin{array}{c}0.001 \\
(0.010)\end{array}$ & $\begin{array}{c}0.008 \\
(0.010)\end{array}$ & $\begin{array}{c}-0.014 \\
(0.013)\end{array}$ & $\begin{array}{c}0.013 \\
(0.012)\end{array}$ & $\begin{array}{c}0.012 \\
(0.013)\end{array}$ \\
\hline NVQ level 3 & $\begin{array}{r}-0.021^{*} \\
(0.011)\end{array}$ & $\begin{array}{r}-0.017^{*} \\
(0.010)\end{array}$ & $\begin{array}{c}-0.003 \\
(0.011)\end{array}$ & $\begin{array}{l}-0.034^{\text {**** }} \\
(0.013)\end{array}$ & $\begin{array}{c}0.003 \\
(0.013)\end{array}$ & $\begin{array}{c}0.002 \\
(0.014)\end{array}$ \\
\hline NVQ level 4 & $\begin{array}{c}-0.013 \\
(0.011)\end{array}$ & $\begin{array}{c}-0.015 \\
(0.010)\end{array}$ & $\begin{array}{c}-0.010 \\
(0.010)\end{array}$ & $\begin{array}{r}-0.023^{*} \\
(0.014)\end{array}$ & $\begin{array}{c}-0.003 \\
(0.013)\end{array}$ & $\begin{array}{c}-0.003 \\
(0.013)\end{array}$ \\
\hline NVQ level 5 & $\begin{array}{c}0.010 \\
(0.021)\end{array}$ & $\begin{array}{c}-0.023 \\
(0.015)\end{array}$ & $\begin{array}{c}-0.031^{* *} \\
(0.013)\end{array}$ & $\begin{array}{c}-0.049^{* *} \\
(0.016)\end{array}$ & $\begin{array}{c}-0.009 \\
(0.019)\end{array}$ & $\begin{array}{l}-0.010 \\
(0.019)\end{array}$ \\
\hline \multicolumn{7}{|l|}{ Ethnicity } \\
\hline Mixed & $\begin{array}{l}0.085^{* * * *} \\
(0.037)\end{array}$ & $\begin{array}{c}0.016 \\
(0.025)\end{array}$ & $\begin{array}{l}-0.023 \\
(0.023)\end{array}$ & $\begin{array}{l}0.037^{* * *} \\
(0.022)\end{array}$ & $\begin{array}{l}-0.006 \\
(0.039)\end{array}$ & $\begin{array}{l}-0.005 \\
(0.040)\end{array}$ \\
\hline Indian & $\begin{array}{c}-0.001 \\
(0.022)\end{array}$ & $\begin{array}{c}0.024 \\
(0.030)\end{array}$ & $\begin{array}{c}0.036 \\
(0.031)\end{array}$ & $\begin{array}{c}-0.031 \\
(0.014)\end{array}$ & $\begin{array}{c}-0.000 \\
(0.023)\end{array}$ & $\begin{array}{l}-0.000 \\
(0.023)\end{array}$ \\
\hline Pakistani and Bangladeshi & $\begin{array}{c}-0.001 \\
(0.013)\end{array}$ & $\begin{array}{l}0.042^{* * * *} \\
(0.018)\end{array}$ & $\begin{array}{c}0.010 \\
(0.015)\end{array}$ & $\begin{array}{c}0.036^{*} \\
(0.023)\end{array}$ & $\begin{array}{c}0.025 \\
(0.024)\end{array}$ & $\begin{array}{c}0.025 \\
(0.025)\end{array}$ \\
\hline Black or Black British & $\begin{array}{l}0.040^{* *} \\
(0.021)\end{array}$ & $\begin{array}{l}0.054^{* * *} \\
(0.023)\end{array}$ & $\begin{array}{l}0.067^{* * *} \\
(0.023)\end{array}$ & $\begin{array}{l}0.041^{* * *} \\
(0.025)\end{array}$ & $\begin{array}{c}0.026 \\
(0.023)\end{array}$ & $\begin{array}{c}0.025 \\
(0.023)\end{array}$ \\
\hline Other Ethnic group (inc Chinese, Other) & $\begin{array}{c}0.021 \\
(0.027)\end{array}$ & $\begin{array}{c}0.015 \\
(0.030)\end{array}$ & $\begin{array}{c}0.035 \\
(0.035)\end{array}$ & $\begin{array}{c}-0.015 \\
(0.023)\end{array}$ & $\begin{array}{c}-0.018 \\
(0.019)\end{array}$ & $\begin{array}{c}-0.018 \\
(0.018)\end{array}$ \\
\hline $\begin{array}{l}\mathbb{E}[\operatorname{Pr}(\text { obese }) \mid x] \\
\mathrm{N}\end{array}$ & $\begin{array}{l}0.036 \\
9,718\end{array}$ & $\begin{array}{r}0.037 \\
10,065\end{array}$ & $\begin{array}{l}0.041 \\
9,271\end{array}$ & $\begin{array}{l}0.039 \\
7,662\end{array}$ & $\begin{array}{l}0.036 \\
6,435\end{array}$ & $\begin{array}{l}0.036 \\
6,435\end{array}$ \\
\hline
\end{tabular}

Note: $* * *$ and $* * *$ denote statistical significance it $10 \%, 5 \%$ and $1 \%$ respectively. The outcome in each column is whether a child is overweight, defined using the the IOTF cutoffs (Table A1). The effects reported are marginal effects obtained after estimating Equation 2 fixing the independent variables at their sample mean. The MCS data does not contain parents' BMI at age 14, so columns 5 and 6 use BMI from age 11 or as predicted to define obesity. All observations are adjusted for the probability of attrition and being sampled, see (Hansen et al., 2014). The omitted categories are income at 9 months: highest quintile; current income quintile and weight category: stayed the same; parents' education: no qualifications; ethnicity: white. $\mathbb{E}[\operatorname{Pr}($ overweight $) \mid x]$ represents the estimated conditional expectation a child is overweight. The main parent is the mother for over $99 \%$ of children at 9 months. Ns differ across columns because of missing data. 
Table B7: The determinants of child overweight and obesity across childhood fixing income and parents' weight at their level when child was 9 months old

\begin{tabular}{|c|c|c|c|c|c|c|}
\hline & \multirow[b]{2}{*}{$\begin{array}{c}\text { (1) } \\
\text { Age } 3\end{array}$} & \multirow[b]{2}{*}{$\begin{array}{l}\text { (2) } \\
\text { Age } 5\end{array}$} & \multirow[b]{2}{*}{$\begin{array}{c}\text { (3) } \\
\text { Age } 7\end{array}$} & \multirow[b]{2}{*}{$\begin{array}{c}\text { (4) } \\
\text { Age } 11\end{array}$} & \multicolumn{2}{|c|}{ (5)-(6) Age 14} \\
\hline & & & & & $\begin{array}{c}\text { Parental weight } \\
\text { constant }\end{array}$ & $\begin{array}{c}\text { Parental weight } \\
\text { predicted }\end{array}$ \\
\hline \multicolumn{7}{|l|}{ Main parent weight category at 9 months } \\
\hline Overweight & $\begin{array}{l}0.061^{\text {**** }} \\
(0.012)\end{array}$ & $\begin{array}{l}0.089^{* * * *} \\
(0.011)\end{array}$ & $\begin{array}{l}0.102^{\text {**** }} \\
(0.012)\end{array}$ & $\begin{array}{l}0.163^{\text {**** }} \\
(0.015)\end{array}$ & $\begin{array}{l}0.141^{\text {**** }} \\
(0.016)\end{array}$ & $\begin{array}{l}0.147^{* * *} \\
(0.016)\end{array}$ \\
\hline Obese/Morbidly obese & $\begin{array}{l}0.112^{\text {**** }} \\
(0.016)\end{array}$ & $\begin{array}{l}0.189^{* * *} \\
(0.017)\end{array}$ & $\begin{array}{l}0.192^{\text {**** }} \\
(0.018)\end{array}$ & $\begin{array}{l}0.321^{\text {**** }} \\
(0.022)\end{array}$ & $\begin{array}{l}0.311^{* * * *} \\
(0.025)\end{array}$ & $\begin{array}{l}0.321^{* * * *} \\
(0.026)\end{array}$ \\
\hline \multicolumn{7}{|l|}{ Current weight } \\
\hline Moved to lighter category & $\begin{array}{c}0.028 \\
(0.018)\end{array}$ & $\begin{array}{c}-0.010 \\
(0.015)\end{array}$ & $\begin{array}{c}-0.006 \\
(0.016)\end{array}$ & $\begin{array}{c}-0.028 \\
(0.020)\end{array}$ & $\begin{array}{l}-0.027 \\
(0.020)\end{array}$ & $\begin{array}{l}-0.035 \\
(0.024)\end{array}$ \\
\hline Moved to heavier category & $\begin{array}{c}0.029^{*} \\
(0.016)\end{array}$ & $\begin{array}{l}0.066^{* * * *} \\
(0.014)\end{array}$ & $\begin{array}{l}0.058^{* * * *} \\
(0.013)\end{array}$ & $\begin{array}{l}0.067^{* * * *} \\
(0.014)\end{array}$ & $\begin{array}{l}0.094^{* * * *} \\
(0.017)\end{array}$ & $\begin{array}{l}0.075^{* * *} \\
(0.014)\end{array}$ \\
\hline \multicolumn{7}{|l|}{ Income quintiles at 9 months } \\
\hline Lowest quintile & $\begin{array}{l}0.064^{* * * *} \\
(0.019)\end{array}$ & $\begin{array}{l}0.061^{* * *} \\
(0.018)\end{array}$ & $\begin{array}{l}0.066^{* * * *} \\
(0.019)\end{array}$ & $\begin{array}{l}0.121^{* * * *} \\
(0.026)\end{array}$ & $\begin{array}{l}0.152^{* * * *} \\
(0.030)\end{array}$ & $\begin{array}{l}0.155^{\text {**** }} \\
(0.030)\end{array}$ \\
\hline Second quintile & $\begin{array}{l}0.046^{* * * *} \\
(0.017)\end{array}$ & $\begin{array}{l}0.035^{* *} \\
(0.016)\end{array}$ & $\begin{array}{l}0.062^{* * * *} \\
(0.016)\end{array}$ & $\begin{array}{l}0.095^{* * * *} \\
(0.022)\end{array}$ & $\begin{array}{l}0.096^{* * *} \\
(0.022)\end{array}$ & $\begin{array}{l}0.096^{* * *} \\
(0.022)\end{array}$ \\
\hline Third quintile & $\begin{array}{c}0.028^{*} \\
(0.015)\end{array}$ & $\begin{array}{c}0.026^{*} \\
(0.014)\end{array}$ & $\begin{array}{l}0.046^{* * * *} \\
(0.015)\end{array}$ & $\begin{array}{l}0.077^{\text {**** }} \\
(0.019)\end{array}$ & $\begin{array}{l}0.078^{* * * *} \\
(0.019)\end{array}$ & $\begin{array}{l}0.079^{\text {**** }} \\
(0.019)\end{array}$ \\
\hline Fourth quintile & $\begin{array}{l}0.034^{* * *} \\
(0.014)\end{array}$ & $\begin{array}{l}0.035^{* * * *} \\
(0.013)\end{array}$ & $\begin{array}{l}0.037^{* * * *} \\
(0.013)\end{array}$ & $\begin{array}{l}0.059^{* * * *} \\
(0.016)\end{array}$ & $\begin{array}{l}0.045^{* * * *} \\
(0.016)\end{array}$ & $\begin{array}{l}0.045^{* * * *} \\
(0.016)\end{array}$ \\
\hline \multicolumn{7}{|l|}{ Current income quintile } \\
\hline Moved down & $\begin{array}{c}-0.010 \\
(0.012)\end{array}$ & $\begin{array}{c}-0.004 \\
(0.011)\end{array}$ & $\begin{array}{c}0.010 \\
(0.012)\end{array}$ & $\begin{array}{c}-0.006 \\
(0.016)\end{array}$ & $\begin{array}{c}0.010 \\
(0.018)\end{array}$ & $\begin{array}{c}0.012 \\
(0.018)\end{array}$ \\
\hline Moved up & $\begin{array}{c}-0.019 \\
(0.011)\end{array}$ & $\begin{array}{c}-0.013 \\
(0.011)\end{array}$ & $\begin{array}{c}0.009 \\
(0.011)\end{array}$ & $\begin{array}{c}-0.019 \\
(0.014)\end{array}$ & $\begin{array}{l}-0.041^{* *} \\
(0.016)\end{array}$ & $\begin{array}{l}-0.041^{* *} \\
(0.016)\end{array}$ \\
\hline Female & $\begin{array}{l}0.076^{\text {**** }} \\
(0.010)\end{array}$ & $\begin{array}{l}0.098^{* * * *} \\
(0.009)\end{array}$ & $\begin{array}{l}0.112^{* * * *} \\
(0.010)\end{array}$ & $\begin{array}{l}0.079^{* * * *} \\
(0.012)\end{array}$ & $\begin{array}{l}0.055^{* * * *} \\
(0.014)\end{array}$ & $\begin{array}{l}0.056^{\text {**** }} \\
(0.014)\end{array}$ \\
\hline Child long-term illness & $\begin{array}{c}0.011 \\
(0.013)\end{array}$ & $\begin{array}{c}0.001 \\
(0.012)\end{array}$ & $\begin{array}{c}-0.009 \\
(0.012)\end{array}$ & $\begin{array}{c}0.004 \\
(0.018)\end{array}$ & $\begin{array}{c}0.003 \\
(0.023)\end{array}$ & $\begin{array}{c}0.002 \\
(0.023)\end{array}$ \\
\hline Health conditions & $\begin{array}{c}0.005 \\
(0.004)\end{array}$ & $\begin{array}{c}0.004 \\
(0.004)\end{array}$ & $\begin{array}{c}0.005 \\
(0.004)\end{array}$ & $\begin{array}{c}0.003 \\
(0.005)\end{array}$ & $\begin{array}{c}0.007 \\
(0.012)\end{array}$ & $\begin{array}{c}0.007 \\
(0.012)\end{array}$ \\
\hline Main parent long-term illness & $\begin{array}{c}-0.015 \\
(0.011)\end{array}$ & $\begin{array}{c}0.002 \\
(0.011)\end{array}$ & $\begin{array}{c}0.021^{*} \\
(0.011)\end{array}$ & $\begin{array}{c}0.010 \\
(0.014)\end{array}$ & $\begin{array}{c}0.009 \\
(0.016)\end{array}$ & $\begin{array}{c}0.012 \\
(0.016)\end{array}$ \\
\hline No. of siblings & $\begin{array}{c}-0.002 \\
(0.005)\end{array}$ & $\begin{array}{c}-0.013^{* * * *} \\
(0.005)\end{array}$ & $\begin{array}{l}-0.018^{* * * *} \\
(0.005)\end{array}$ & $\begin{array}{l}-0.027^{* * * *} \\
(0.007)\end{array}$ & $\begin{array}{l}-0.024^{* * *} \\
(0.007)\end{array}$ & $\begin{array}{l}-0.023^{* * * *} \\
(0.007)\end{array}$ \\
\hline Birthweight & $\begin{array}{l}0.114^{* * * *} \\
(0.009)\end{array}$ & $\begin{array}{l}0.101^{* * * *} \\
(0.009)\end{array}$ & $\begin{array}{l}0.057^{* * * *} \\
(0.009)\end{array}$ & $\begin{array}{l}0.035^{\text {**** }} \\
(0.011)\end{array}$ & $\begin{array}{l}0.041^{* * *} \\
(0.011)\end{array}$ & $\begin{array}{l}0.043^{* * * *} \\
(0.011)\end{array}$ \\
\hline Weight gain 9 months-3 $(\mathrm{kg})$ & $\begin{array}{l}0.092^{* * * *} \\
(0.005)\end{array}$ & $\begin{array}{l}0.078^{* * *} \\
(0.005)\end{array}$ & $\begin{array}{l}0.052^{\text {**** }} \\
(0.005)\end{array}$ & $\begin{array}{l}0.044^{* * * *} \\
(0.005)\end{array}$ & $\begin{array}{l}0.031^{* * *} \\
(0.007)\end{array}$ & $\begin{array}{l}0.031^{* * *} \\
(0.007)\end{array}$ \\
\hline \multicolumn{7}{|l|}{$\underline{\text { Main Parent's education }}$} \\
\hline NVQ level 1 & $\begin{array}{c}-0.009 \\
(0.023)\end{array}$ & $\begin{array}{c}0.008 \\
(0.022)\end{array}$ & $\begin{array}{l}-0.029 \\
(0.021)\end{array}$ & $\begin{array}{c}-0.004 \\
(0.029)\end{array}$ & $\begin{array}{c}-0.001 \\
(0.036)\end{array}$ & $\begin{array}{l}-0.004 \\
(0.037)\end{array}$ \\
\hline NVQ level 2 & $\begin{array}{c}-0.027 \\
(0.019)\end{array}$ & $\begin{array}{c}-0.013 \\
(0.017)\end{array}$ & $\begin{array}{c}0.005 \\
(0.018)\end{array}$ & $\begin{array}{c}-0.011 \\
(0.023)\end{array}$ & $\begin{array}{c}-0.009 \\
(0.027)\end{array}$ & $\begin{array}{l}-0.011 \\
(0.027)\end{array}$ \\
\hline NVQ level 3 & $\begin{array}{c}-0.028 \\
(0.021)\end{array}$ & $\begin{array}{c}-0.019 \\
(0.019)\end{array}$ & $\begin{array}{l}-0.027 \\
(0.020)\end{array}$ & $\begin{array}{c}-0.043^{*} \\
(0.025)\end{array}$ & $\begin{array}{c}-0.041 \\
(0.028)\end{array}$ & $\begin{array}{l}-0.043 \\
(0.028)\end{array}$ \\
\hline NVQ level 4 & $\begin{array}{c}-0.020 \\
(0.020)\end{array}$ & $\begin{array}{c}-0.014 \\
(0.019)\end{array}$ & $\begin{array}{c}-0.012 \\
(0.019)\end{array}$ & $\begin{array}{c}-0.028 \\
(0.026)\end{array}$ & $\begin{array}{c}-0.019 \\
(0.028)\end{array}$ & $\begin{array}{c}-0.022 \\
(0.028)\end{array}$ \\
\hline NVQ level 5 & $\begin{array}{c}0.047 \\
(0.033)\end{array}$ & $\begin{array}{c}-0.019 \\
(0.029)\end{array}$ & $\begin{array}{l}-0.028 \\
(0.029)\end{array}$ & $\begin{array}{r}-0.063^{*} \\
(0.037)\end{array}$ & $\begin{array}{c}-0.055 \\
(0.037)\end{array}$ & $\begin{array}{l}-0.058 \\
(0.038)\end{array}$ \\
\hline \multicolumn{7}{|l|}{ Ethnicity } \\
\hline Mixed & $\begin{array}{c}0.098^{*} \\
(0.055)\end{array}$ & $\begin{array}{c}0.014 \\
(0.045)\end{array}$ & $\begin{array}{l}-0.054 \\
(0.046)\end{array}$ & $\begin{array}{l}0.074^{* *} \\
(0.037)\end{array}$ & $\begin{array}{c}-0.014 \\
(0.065)\end{array}$ & $\begin{array}{c}-0.012 \\
(0.065)\end{array}$ \\
\hline Indian & $\begin{array}{l}-0.085^{* *} \\
(0.033)\end{array}$ & $\begin{array}{c}0.022 \\
(0.044)\end{array}$ & $\begin{array}{l}0.088^{* * *} \\
(0.042)\end{array}$ & $\begin{array}{c}0.032 \\
(0.048)\end{array}$ & $\begin{array}{c}0.113 \\
(0.100)\end{array}$ & $\begin{array}{c}0.116 \\
(0.104)\end{array}$ \\
\hline Pakistani and Bangladeshi & $\begin{array}{c}-0.026 \\
(0.025)\end{array}$ & $\begin{array}{c}0.009 \\
(0.026)\end{array}$ & $\begin{array}{c}0.019 \\
(0.029)\end{array}$ & $\begin{array}{l}0.069^{* *} \\
(0.035)\end{array}$ & $\begin{array}{c}0.005 \\
(0.034)\end{array}$ & $\begin{array}{c}0.005 \\
(0.034)\end{array}$ \\
\hline Black or Black British & $\begin{array}{l}0.066^{* * *} \\
(0.036)\end{array}$ & $\begin{array}{l}0.101^{* * *} \\
(0.035)\end{array}$ & $\begin{array}{l}0.102^{* * *} \\
(0.036)\end{array}$ & $\begin{array}{l}0.133^{* * *} \\
(0.045)\end{array}$ & $\begin{array}{c}0.055 \\
(0.040)\end{array}$ & $\begin{array}{c}0.053 \\
(0.040)\end{array}$ \\
\hline Other Ethnic group (inc Chinese, Other) & $\begin{array}{c}0.002 \\
(0.044)\end{array}$ & $\begin{array}{c}-0.034 \\
(0.041)\end{array}$ & $\begin{array}{c}-0.001 \\
(0.048)\end{array}$ & $\begin{array}{c}-0.006 \\
(0.068)\end{array}$ & $\begin{array}{c}0.060 \\
(0.076)\end{array}$ & $\begin{array}{c}0.058 \\
(0.077)\end{array}$ \\
\hline $\begin{array}{l}\mathbb{E}[\operatorname{Pr}(\text { overweight } \cup \text { obese }) \mid x] \\
\mathrm{N}\end{array}$ & $\begin{array}{l}0.196 \\
9,718\end{array}$ & $\begin{array}{r}0.172 \\
10,065\end{array}$ & $\begin{array}{l}0.163 \\
9,271\end{array}$ & $\begin{array}{l}0.237 \\
7.662\end{array}$ & $\begin{array}{l}0.193 \\
6,435\end{array}$ & $\begin{array}{l}0.193 \\
6.435\end{array}$ \\
\hline
\end{tabular}

Note: $* * *$ and $* * *$ denote statistical significance it $10 \%, 5 \%$ and $1 \%$ respectively. The outcome in each column is whether a child is overweight, defined using the the IOTF cutoffs (Table A1). The effects reported are marginal effects obtained after estimating Equation 2 fixing the independent variables at their sample mean. The MCS data does not contain parents' BMI at age 14, so columns 5 and 6 use BMI from age 11 or as predicted to define obesity. All observations are adjusted for the probability of attrition and being sampled, see (Hansen et al., 2014). The omitted categories are income at 9 months: highest quintile; current income quintile and weight category: stayed the same; parents' education: no qualifications; ethnicity: white. $\mathbb{E}[\operatorname{Pr}($ overweight $) \mid x]$ represents the estimated conditional expectation a child is overweight. The main parent is the mother for over $99 \%$ of children at 9 months. Ns differ across columns because of missing data. 


\section{B.2 Additional tables of the determinants of healthy behaviours across ages}

Table B8: Determinants of healthy behaviour index across ages with full controls

\begin{tabular}{|c|c|c|c|c|c|c|}
\hline & & & & & $(5)-(6)$ & Age 14 \\
\hline & $\begin{array}{c}\text { (1) } \\
\text { Age } 3\end{array}$ & $\begin{array}{c}\text { (2) } \\
\text { Age } 5\end{array}$ & $\begin{array}{c}\text { (3) } \\
\text { Age } 7\end{array}$ & $\begin{array}{c}(4) \\
\text { Age } 11\end{array}$ & $\begin{array}{l}\text { Parental weight } \\
\text { constant }\end{array}$ & $\begin{array}{c}\text { Parental weight } \\
\text { predicted }\end{array}$ \\
\hline Child overweight or obese & $\begin{array}{c}0.008 \\
(0.014)\end{array}$ & $\begin{array}{c}0.012 \\
(0.015)\end{array}$ & $\begin{array}{l}-0.016 \\
(0.016)\end{array}$ & $\begin{array}{l}-0.065^{* * *} \\
(0.016)\end{array}$ & $\begin{array}{c}-0.027^{*} \\
(0.016)\end{array}$ & $\begin{array}{l}-0.029^{*} \\
(0.016)\end{array}$ \\
\hline Main parent overweight & $\begin{array}{c}-0.009 \\
(0.013)\end{array}$ & $\begin{array}{l}-0.037^{* * *} \\
(0.013)\end{array}$ & $\begin{array}{l}-0.066^{* * * *} \\
(0.014)\end{array}$ & $\begin{array}{r}-0.029^{*} \\
(0.016)\end{array}$ & $\begin{array}{l}-0.057^{* * *} \\
(0.015)\end{array}$ & $\begin{array}{l}-0.062^{* * * *} \\
(0.015)\end{array}$ \\
\hline Main parent obese/morbidly obese & $\begin{array}{l}-0.025 \\
(0.017)\end{array}$ & $\begin{array}{l}-0.061^{* * *} \\
(0.016)\end{array}$ & $\begin{array}{l}-0.112^{* * *} \\
(0.017)\end{array}$ & $\begin{array}{l}-0.051^{* * * *} \\
(0.020)\end{array}$ & $\begin{array}{l}-0.094^{* * *} \\
(0.017)\end{array}$ & $\begin{array}{l}-0.095^{* * *} \\
(0.018)\end{array}$ \\
\hline Income quintiles & & & & & & \\
\hline Lowest quintile & $\begin{array}{c}-0.027 \\
(0.021)\end{array}$ & $\begin{array}{l}-0.172^{* * *} \\
(0.020)\end{array}$ & $\begin{array}{c}-0.047^{* *} \\
(0.022)\end{array}$ & $\begin{array}{l}-0.244^{* * * *} \\
(0.030)\end{array}$ & $\begin{array}{l}-0.209^{* * *} \\
(0.028)\end{array}$ & $\begin{array}{l}-0.211^{* * * *} \\
(0.028)\end{array}$ \\
\hline Second quintile & $\begin{array}{c}0.001 \\
(0.020)\end{array}$ & $\begin{array}{l}-0.121^{\text {**** }} \\
(0.019)\end{array}$ & $\begin{array}{l}-0.074^{* * *} \\
(0.020)\end{array}$ & $\begin{array}{l}-0.212^{* * * *} \\
(0.025)\end{array}$ & $\begin{array}{l}-0.169^{* * *} \\
(0.023)\end{array}$ & $\begin{array}{l}-0.170^{* * * *} \\
(0.023)\end{array}$ \\
\hline Third quintile & $\begin{array}{c}-0.011 \\
(0.018)\end{array}$ & $\begin{array}{l}-0.082^{* * *} \\
(0.018)\end{array}$ & $\begin{array}{l}-0.060^{* * * *} \\
(0.019)\end{array}$ & $\begin{array}{l}-0.135^{* * *} \\
(0.022)\end{array}$ & $\begin{array}{l}-0.109^{* * *} \\
(0.020)\end{array}$ & $\begin{array}{l}-0.110^{* * * *} \\
(0.020)\end{array}$ \\
\hline Fourth quintile & $\begin{array}{c}0.014 \\
(0.017)\end{array}$ & $\begin{array}{l}-0.051^{* * *} \\
(0.017)\end{array}$ & $\begin{array}{c}-0.026 \\
(0.018)\end{array}$ & $\begin{array}{l}-0.063^{* * * *} \\
(0.020)\end{array}$ & $\begin{array}{l}-0.058^{* * *} \\
(0.018)\end{array}$ & $\begin{array}{l}-0.057^{* * * *} \\
(0.018)\end{array}$ \\
\hline Main parent's education & & & & & & \\
\hline NVQ level 1 & $\begin{array}{c}-0.007 \\
(0.026)\end{array}$ & $\begin{array}{c}0.029 \\
(0.024)\end{array}$ & $\begin{array}{c}0.034 \\
(0.028)\end{array}$ & $\begin{array}{c}-0.017 \\
(0.034)\end{array}$ & $\begin{array}{l}-0.031 \\
(0.034)\end{array}$ & $\begin{array}{l}-0.028 \\
(0.034)\end{array}$ \\
\hline NVQ level 2 & $\begin{array}{l}-0.010 \\
(0.020)\end{array}$ & $\begin{array}{l}0.108^{* * *} \\
(0.019)\end{array}$ & $\begin{array}{l}0.055^{* *} \\
(0.022)\end{array}$ & $\begin{array}{c}0.036 \\
(0.029)\end{array}$ & $\begin{array}{c}0.000 \\
(0.027)\end{array}$ & $\begin{array}{c}0.001 \\
(0.027)\end{array}$ \\
\hline NVQ level 3 & $\begin{array}{r}0.042^{*} \\
(0.023)\end{array}$ & $\begin{array}{l}0.169^{* * *} \\
(0.022)\end{array}$ & $\begin{array}{l}0.096^{* * *} \\
(0.025)\end{array}$ & $\begin{array}{l}0.092^{* * * *} \\
(0.031)\end{array}$ & $\begin{array}{c}0.055^{*} \\
(0.030)\end{array}$ & $\begin{array}{r}0.056^{*} \\
(0.030)\end{array}$ \\
\hline NVQ level 4 & $\begin{array}{c}0.031 \\
(0.022)\end{array}$ & $\begin{array}{l}0.249^{* * * *} \\
(0.020)\end{array}$ & $\begin{array}{l}0.112^{* * * *} \\
(0.024)\end{array}$ & $\begin{array}{l}0.183^{\text {**** }} \\
(0.030)\end{array}$ & $\begin{array}{l}0.132^{* * * *} \\
(0.029)\end{array}$ & $\begin{array}{l}0.133^{* * *} \\
(0.029)\end{array}$ \\
\hline NVQ level 5 & $\begin{array}{c}0.009 \\
(0.034)\end{array}$ & $\begin{array}{l}0.259^{* * * *} \\
(0.034)\end{array}$ & $\begin{array}{l}0.103^{* * *} \\
(0.036)\end{array}$ & $\begin{array}{l}0.295^{* * * *} \\
(0.044)\end{array}$ & $\begin{array}{l}0.231^{* * *} \\
(0.043)\end{array}$ & $\begin{array}{l}0.231^{* * * *} \\
(0.043)\end{array}$ \\
\hline Female & $\begin{array}{c}-0.000 \\
(0.012)\end{array}$ & $\begin{array}{c}0.004 \\
(0.012)\end{array}$ & $\begin{array}{l}-0.029^{* *} \\
(0.012)\end{array}$ & $\begin{array}{c}-0.008 \\
(0.014)\end{array}$ & $\begin{array}{c}-0.018 \\
(0.013)\end{array}$ & $\begin{array}{l}-0.018 \\
(0.013)\end{array}$ \\
\hline Child long-term illness & $\begin{array}{c}0.002 \\
(0.016)\end{array}$ & $\begin{array}{c}-0.012 \\
(0.016)\end{array}$ & $\begin{array}{c}-0.004 \\
(0.017)\end{array}$ & $\begin{array}{c}-0.036 \\
(0.023)\end{array}$ & $\begin{array}{c}0.004 \\
(0.025)\end{array}$ & $\begin{array}{c}0.005 \\
(0.025)\end{array}$ \\
\hline Health conditions & $\begin{array}{r}0.009^{*} \\
(0.005)\end{array}$ & $\begin{array}{c}0.007 \\
(0.005)\end{array}$ & $\begin{array}{c}0.001 \\
(0.005)\end{array}$ & $\begin{array}{r}-0.009^{*} \\
(0.006)\end{array}$ & $\begin{array}{c}0.008 \\
(0.013)\end{array}$ & $\begin{array}{c}0.008 \\
(0.013)\end{array}$ \\
\hline Main parent long-term illness & $\begin{array}{c}-0.005 \\
(0.014)\end{array}$ & $\begin{array}{c}0.006 \\
(0.014)\end{array}$ & $\begin{array}{c}0.006 \\
(0.015)\end{array}$ & $\begin{array}{c}-0.016 \\
(0.017)\end{array}$ & $\begin{array}{c}-0.023 \\
(0.015)\end{array}$ & $\begin{array}{c}-0.025 \\
(0.015)\end{array}$ \\
\hline No. of siblings & $\begin{array}{l}0.014^{* *} \\
(0.006)\end{array}$ & $\begin{array}{c}-0.002 \\
(0.006)\end{array}$ & $\begin{array}{c}-0.006 \\
(0.006)\end{array}$ & $\begin{array}{c}0.009 \\
(0.008)\end{array}$ & $\begin{array}{l}0.016^{* *} \\
(0.007)\end{array}$ & $\begin{array}{l}0.015^{* *} \\
(0.007)\end{array}$ \\
\hline Birthweight & $\begin{array}{c}0.023^{* *} \\
(0.010)\end{array}$ & $\begin{array}{c}0.014 \\
(0.010)\end{array}$ & $\begin{array}{c}0.009 \\
(0.011)\end{array}$ & $\begin{array}{c}0.004 \\
(0.012)\end{array}$ & $\begin{array}{c}0.001 \\
(0.012)\end{array}$ & $\begin{array}{c}-0.000 \\
(0.012)\end{array}$ \\
\hline Weight gain 9 months -3 (kg) & $\begin{array}{c}0.007 \\
(0.005)\end{array}$ & $\begin{array}{c}0.006 \\
(0.005)\end{array}$ & $\begin{array}{c}0.007 \\
(0.005)\end{array}$ & $\begin{array}{c}0.005 \\
(0.006)\end{array}$ & $\begin{array}{c}-0.004 \\
(0.006)\end{array}$ & $\begin{array}{c}-0.004 \\
(0.006)\end{array}$ \\
\hline Ethnicity & & & & & & \\
\hline Mixed & $\begin{array}{c}-0.052 \\
(0.060)\end{array}$ & $\begin{array}{c}-0.081 \\
(0.065)\end{array}$ & $\begin{array}{c}-0.155^{* *} \\
(0.066)\end{array}$ & $\begin{array}{c}-0.024 \\
(0.046)\end{array}$ & $\begin{array}{c}-0.043 \\
(0.067)\end{array}$ & $\begin{array}{c}-0.041 \\
(0.067)\end{array}$ \\
\hline Indian & $\begin{array}{c}0.001 \\
(0.040)\end{array}$ & $\begin{array}{l}-0.131^{* * *} \\
(0.036)\end{array}$ & $\begin{array}{c}-0.114^{* *} \\
(0.043)\end{array}$ & $\begin{array}{c}-0.039 \\
(0.052)\end{array}$ & $\begin{array}{l}0.109^{* *} \\
(0.051)\end{array}$ & $\begin{array}{l}0.110^{* *} \\
(0.052)\end{array}$ \\
\hline Pakistani and Bangladeshi & $\begin{array}{l}-0.089^{* * *} \\
(0.027)\end{array}$ & $\begin{array}{l}-0.258^{* * *} \\
(0.023)\end{array}$ & $\begin{array}{c}-0.191^{* * *} \\
(0.029)\end{array}$ & $\begin{array}{c}-0.042 \\
(0.040)\end{array}$ & $\begin{array}{c}0.033 \\
(0.047)\end{array}$ & $\begin{array}{c}0.035 \\
(0.047)\end{array}$ \\
\hline Black or Black British & $\begin{array}{c}-0.114^{* * *} \\
(0.034)\end{array}$ & $\begin{array}{l}-0.252^{* * *} \\
(0.025)\end{array}$ & $\begin{array}{c}-0.234^{* * *} \\
(0.033)\end{array}$ & $\begin{array}{c}0.035 \\
(0.053)\end{array}$ & $\begin{array}{c}-0.008 \\
(0.075)\end{array}$ & $\begin{array}{c}-0.007 \\
(0.074)\end{array}$ \\
\hline Other Ethnic group (inc Chinese,Other) & $\begin{array}{c}-0.142^{* * * *} \\
(0.040)\end{array}$ & $\begin{array}{l}-0.161^{* * *} \\
(0.042)\end{array}$ & $\begin{array}{c}-0.071 \\
(0.052)\end{array}$ & $\begin{array}{c}0.017 \\
(0.077)\end{array}$ & $\begin{array}{r}0.106^{*} \\
(0.069)\end{array}$ & $\begin{array}{c}0.107^{*} \\
(0.070)\end{array}$ \\
\hline $\mathbb{E}[\operatorname{Pr}($ Healthybehaviour $) \mid x]$ & 0.382 & 0.378 & 0.448 & 0.415 & 0.251 & \\
\hline $\mathrm{N}$ & 10,714 & 11,119 & 10,186 & 8,426 & 7,067 & 7,067 \\
\hline
\end{tabular}

Note: $*, * *$ and $* * *$ denote statistical significance it $10 \%, 5 \%$ and $1 \%$ respectively. The outcome in each column is whether a child displays healthy behaviour as defined in Appendix A.2. The effects reported are marginal effects obtained after estimating Equation 3 fixing the independent variables at their sample mean. The MCS data does not contain parents' BMI at age 14, so columns 5 and 6 use BMI from age 11 or as predicted to define obesity. All observations are adjusted for the probability of attrition and being sampled, see (Hansen et al., 2014). The omitted categories are income: highest quintile; parents' education: no qualifications; ethnicity: white. $\mathbb{E}[\operatorname{Pr}($ Healthybehaviour $) \mid \boldsymbol{x}]$ represents the estimated conditional expectation a child exhibits healthy behaviour. The main parent is the mother for over $99 \%$ of children at 9 months. Ns differ across columns because of missing data. 
Table B9: Determinants of individual healthy behaviours at age 3

\begin{tabular}{|c|c|c|c|}
\hline & $\begin{array}{c}\text { Fresh fruit/veg } \\
\text { once a day }\end{array}$ & $\begin{array}{l}\text { Child has } \\
\text { regular meal times }\end{array}$ & $\begin{array}{l}\text { Someone does } \\
\text { sport with child }\end{array}$ \\
\hline Child overweight or obese & $\begin{array}{c}0.003 \\
(0.005)\end{array}$ & $\begin{array}{c}0.000 \\
(0.014)\end{array}$ & $\begin{array}{c}0.007 \\
(0.011)\end{array}$ \\
\hline Main parent overweight & $\begin{array}{l}0.000 \\
(0.005)\end{array}$ & $\begin{array}{l}-0.001 \\
(0.013)\end{array}$ & $\begin{array}{c}0.003 \\
(0.011)\end{array}$ \\
\hline Main parent obese/morbidly obese & $\begin{array}{l}-0.004 \\
(0.006)\end{array}$ & $\begin{array}{l}-0.022 \\
(0.017)\end{array}$ & $\begin{array}{c}0.001 \\
(0.013)\end{array}$ \\
\hline \multicolumn{4}{|l|}{ Equivalised household income quintiles } \\
\hline Lowest quintile & $\begin{array}{l}-0.034^{* * *} \\
(0.007)\end{array}$ & $\begin{array}{c}0.031 \\
(0.021)\end{array}$ & $\begin{array}{l}-0.072^{* * *} \\
(0.017)\end{array}$ \\
\hline Second quintile & $\begin{array}{l}-0.033^{* * *} \\
(0.006)\end{array}$ & $\begin{array}{l}0.028 \\
(0.020)\end{array}$ & $\begin{array}{l}-0.048^{* * *} \\
(0.015)\end{array}$ \\
\hline Third quintile & $\begin{array}{r}-0.009^{*} \\
(0.005)\end{array}$ & $\begin{array}{c}0.010 \\
(0.019)\end{array}$ & $\begin{array}{l}-0.049^{* * *} \\
(0.014)\end{array}$ \\
\hline Fourth quintile & $\begin{array}{l}-0.011^{* *} \\
(0.005)\end{array}$ & $\begin{array}{r}0.035^{*} \\
(0.018)\end{array}$ & $\begin{array}{l}-0.023 \\
(0.014)\end{array}$ \\
\hline Female & $\begin{array}{l}-0.000 \\
(0.004)\end{array}$ & $\begin{array}{c}0.013 \\
(0.012)\end{array}$ & $\begin{array}{l}-0.029^{* * *} \\
(0.009)\end{array}$ \\
\hline Child long-term illness & $\begin{array}{l}-0.005 \\
(0.006)\end{array}$ & $\begin{array}{l}-0.017 \\
(0.016)\end{array}$ & $\begin{array}{r}0.022^{*} \\
(0.012)\end{array}$ \\
\hline Health conditions & $\begin{array}{l}-0.001 \\
(0.002)\end{array}$ & $\begin{array}{c}0.008 \\
(0.006)\end{array}$ & $\begin{array}{r}0.009^{*} \\
(0.005)\end{array}$ \\
\hline Main parent long-term illness & $\begin{array}{c}0.001 \\
(0.005)\end{array}$ & $\begin{array}{l}-0.019 \\
(0.014)\end{array}$ & $\begin{array}{c}0.013 \\
(0.011)\end{array}$ \\
\hline No. of siblings & $\begin{array}{c}0.003 \\
(0.002)\end{array}$ & $\begin{array}{c}0.008 \\
(0.006)\end{array}$ & $\begin{array}{l}0.011^{* *} \\
(0.004)\end{array}$ \\
\hline Birthweight & $\begin{array}{c}0.003 \\
(0.004)\end{array}$ & $\begin{array}{l}0.023^{* *} \\
(0.010)\end{array}$ & $\begin{array}{c}0.007 \\
(0.008)\end{array}$ \\
\hline Weight gain 9 months-3 (kg) & $\begin{array}{c}-0.001 \\
(0.002)\end{array}$ & $\begin{array}{c}0.006 \\
(0.005)\end{array}$ & $\begin{array}{c}0.003 \\
(0.004)\end{array}$ \\
\hline \multicolumn{4}{|l|}{ Main parent's education } \\
\hline NVQ level 1 & $\begin{array}{l}-0.006 \\
(0.010)\end{array}$ & $\begin{array}{l}-0.021 \\
(0.026)\end{array}$ & $\begin{array}{c}0.017 \\
(0.021)\end{array}$ \\
\hline NVQ level 2 & $\begin{array}{c}0.011 \\
(0.008)\end{array}$ & $\begin{array}{c}-0.029 \\
(0.021)\end{array}$ & $\begin{array}{c}0.015 \\
(0.016)\end{array}$ \\
\hline NVQ level 3 & $\begin{array}{l}0.019^{* *} \\
(0.009)\end{array}$ & $\begin{array}{c}0.034 \\
(0.024)\end{array}$ & $\begin{array}{c}0.024 \\
(0.019)\end{array}$ \\
\hline NVQ level 4 & $\begin{array}{l}0.034^{* * *} \\
(0.008)\end{array}$ & $\begin{array}{c}0.010 \\
(0.023)\end{array}$ & $\begin{array}{l}0.037^{* *} \\
(0.018)\end{array}$ \\
\hline NVQ level 5 & $\begin{array}{l}0.034^{* *} \\
(0.011)\end{array}$ & $\begin{array}{c}0.000 \\
(0.035)\end{array}$ & $\begin{array}{c}0.022 \\
(0.029)\end{array}$ \\
\hline \multicolumn{4}{|l|}{ Ethnicity } \\
\hline Mixed & $\begin{array}{l}-0.005 \\
(0.019)\end{array}$ & $\begin{array}{l}-0.005 \\
(0.064)\end{array}$ & $\begin{array}{l}-0.015 \\
(0.052)\end{array}$ \\
\hline Indian & $\begin{array}{l}0.028^{* * *} \\
(0.004)\end{array}$ & $\begin{array}{l}-0.000 \\
(0.041)\end{array}$ & $\begin{array}{l}-0.006 \\
(0.031)\end{array}$ \\
\hline Pakistani and Bangladeshi & $\begin{array}{l}0.021^{* * *} \\
(0.004)\end{array}$ & $\begin{array}{l}-0.070^{* *} \\
(0.028)\end{array}$ & $\begin{array}{l}-0.138^{* * *} \\
(0.026)\end{array}$ \\
\hline Black or Black British & $\begin{array}{l}-0.015 \\
(0.014)\end{array}$ & $\begin{array}{l}-0.170^{* * *} \\
(0.034)\end{array}$ & $\begin{array}{l}-0.010 \\
(0.029)\end{array}$ \\
\hline Other Ethnic group (inc Chinese,Other) & $\begin{array}{c}0.021 \\
(0.008)\end{array}$ & $\begin{array}{l}-0.147^{* * *} \\
(0.045)\end{array}$ & $\begin{array}{l}-0.057 \\
(0.042)\end{array}$ \\
\hline $\begin{array}{l}\text { Outcome mean } \\
\mathrm{N}\end{array}$ & $\begin{array}{c}0.97 \\
10,714\end{array}$ & $\begin{array}{c}0.47 \\
10,714\end{array}$ & $\begin{array}{c}0.79 \\
10,714\end{array}$ \\
\hline
\end{tabular}

Note: $*$, ** and $* * *$ denote statistical significance it $10 \%, 5 \%$ and $1 \%$ respectively. The outcome in each column is the healthy behaviour indicated at the top of the column. See appendix Table A6(a) for how they were constructed. The effects reported are marginal effects obtained after estimating Equation 3 with the outcome in each column as the dependent variable and fixing the independent variables at their sample mean. All observations are adjusted for the probability of attrition and being sampled, see (Hansen et al., 2014). The omitted categories are income: highest quintile; parents' education: no qualifications; ethnicity: white. Female is an indicator of whether a child is female. Child overweight/obesity is defined using the the IOTF cutoffs (Table A1). The outcome mean represents the unconditional probability a child engages in each healthy behaviour. 
Table B10: Determinants of individual healthy behaviours at age 5

\begin{tabular}{|c|c|c|c|c|c|}
\hline & Fresh fruit/veg once a day & $\begin{array}{l}\text { Child has } \\
\text { regular meal times }\end{array}$ & $\begin{array}{l}\text { Plays physically } \\
\text { active games }\end{array}$ & $\begin{array}{l}\text { Child play sport } \\
\text { once a week }\end{array}$ & $\begin{array}{l}\text { Does sport/exercise with } \\
\text { child once a week }\end{array}$ \\
\hline Child overweight or obese & $\begin{array}{c}0.009 \\
(0.014)\end{array}$ & $\begin{array}{c}0.011 \\
(0.014)\end{array}$ & $\begin{array}{c}0.011 \\
(0.014)\end{array}$ & $\begin{array}{l}-0.007 \\
(0.013)\end{array}$ & $\begin{array}{c}0.010 \\
(0.013)\end{array}$ \\
\hline Main parent overweight & $\begin{array}{c}0.001 \\
(0.013)\end{array}$ & $\begin{array}{c}-0.032^{* *} \\
(0.013)\end{array}$ & $\begin{array}{c}-0.037^{* * *} \\
(0.013)\end{array}$ & $\begin{array}{c}-0.032^{* * *} \\
(0.012)\end{array}$ & $\begin{array}{l}-0.018 \\
(0.012)\end{array}$ \\
\hline Main parent obese/morbidly obese & $\begin{array}{c}0.005 \\
(0.016)\end{array}$ & $\begin{array}{c}-0.056^{* * *} \\
(0.016)\end{array}$ & $\begin{array}{c}-0.087^{* * *} \\
(0.016)\end{array}$ & $\begin{array}{l}-0.079^{* * *} \\
(0.015)\end{array}$ & $\begin{array}{c}-0.035^{* *} \\
(0.015)\end{array}$ \\
\hline \multicolumn{6}{|l|}{ Equivalised household income quintiles } \\
\hline Lowest quintile & $\begin{array}{c}-0.138^{* * *} \\
(0.021)\end{array}$ & $\begin{array}{l}-0.016 \\
(0.020)\end{array}$ & $\begin{array}{c}-0.010 \\
(0.020)\end{array}$ & $\begin{array}{l}-0.292^{* * *} \\
(0.020)\end{array}$ & $\begin{array}{c}-0.086^{* * *} \\
(0.019)\end{array}$ \\
\hline Second quintile & $\begin{array}{c}-0.102^{* * *} \\
(0.019)\end{array}$ & $\begin{array}{c}0.023 \\
(0.019)\end{array}$ & $\begin{array}{c}-0.019 \\
(0.019)\end{array}$ & $\begin{array}{c}-0.232^{* * *} \\
(0.018)\end{array}$ & $\begin{array}{c}-0.049^{* * *} \\
(0.018)\end{array}$ \\
\hline Third quintile & $\begin{array}{c}-0.084^{* * *} \\
(0.018)\end{array}$ & $\begin{array}{c}0.016 \\
(0.018)\end{array}$ & $\begin{array}{c}-0.021 \\
(0.018)\end{array}$ & $\begin{array}{c}-0.141^{* * *} \\
(0.017)\end{array}$ & $\begin{array}{r}-0.028^{*} \\
(0.017)\end{array}$ \\
\hline Fourth quintile & $\begin{array}{c}-0.063^{* * *} \\
(0.017)\end{array}$ & $\begin{array}{c}0.012 \\
(0.017)\end{array}$ & $\begin{array}{c}-0.017 \\
(0.017)\end{array}$ & $\begin{array}{c}-0.077^{* * *} \\
(0.016)\end{array}$ & $\begin{array}{l}-0.047^{* * *} \\
(0.016)\end{array}$ \\
\hline Female & $\begin{array}{c}0.028^{* *} \\
(0.011)\end{array}$ & $\begin{array}{c}0.006 \\
(0.011)\end{array}$ & $\begin{array}{c}-0.043^{* * *} \\
(0.011)\end{array}$ & $\begin{array}{l}0.082^{* * *} \\
(0.010)\end{array}$ & $\begin{array}{c}-0.042^{* * *} \\
(0.010)\end{array}$ \\
\hline Child long-term illness & $\begin{array}{c}-0.004 \\
(0.015)\end{array}$ & $\begin{array}{c}-0.002 \\
(0.015)\end{array}$ & $\begin{array}{c}-0.022 \\
(0.015)\end{array}$ & $\begin{array}{l}-0.017 \\
(0.014)\end{array}$ & $\begin{array}{c}-0.013 \\
(0.014)\end{array}$ \\
\hline Health conditions & $\begin{array}{c}0.004 \\
(0.005)\end{array}$ & $\begin{array}{c}0.008 \\
(0.005)\end{array}$ & $\begin{array}{c}0.005 \\
(0.005)\end{array}$ & $\begin{array}{c}0.004 \\
(0.005)\end{array}$ & $\begin{array}{c}0.001 \\
(0.005)\end{array}$ \\
\hline Main parent long-term illness & $\begin{array}{l}-0.008 \\
(0.013)\end{array}$ & $\begin{array}{c}-0.003 \\
(0.013)\end{array}$ & $\begin{array}{l}-0.011 \\
(0.013)\end{array}$ & $\begin{array}{l}-0.015 \\
(0.012)\end{array}$ & $\begin{array}{c}0.007 \\
(0.012)\end{array}$ \\
\hline No. of siblings & $\begin{array}{c}0.014^{* *} \\
(0.006)\end{array}$ & $\begin{array}{l}0.020^{* * *} \\
(0.006)\end{array}$ & $\begin{array}{l}-0.036^{* * *} \\
(0.006)\end{array}$ & $\begin{array}{l}-0.018^{* * *} \\
(0.005)\end{array}$ & $\begin{array}{c}-0.018^{* * *} \\
(0.005)\end{array}$ \\
\hline Birthweight & $\begin{array}{c}0.010 \\
(0.010)\end{array}$ & $\begin{array}{r}0.019^{*} \\
(0.010)\end{array}$ & $\begin{array}{l}-0.001 \\
(0.010)\end{array}$ & $\begin{array}{l}0.034^{* * *} \\
(0.009)\end{array}$ & $\begin{array}{c}0.006 \\
(0.009)\end{array}$ \\
\hline Weight gain 9 months- 3 (kg) & $\begin{array}{c}0.008^{*} \\
(0.005)\end{array}$ & $\begin{array}{c}0.003 \\
(0.005)\end{array}$ & $\begin{array}{c}-0.009^{* *} \\
(0.005)\end{array}$ & $\begin{array}{l}0.015^{* * *} \\
(0.004)\end{array}$ & $\begin{array}{c}0.000 \\
(0.004)\end{array}$ \\
\hline \multicolumn{6}{|l|}{ Main parent's education } \\
\hline NVQ level 1 & $\begin{array}{c}-0.004 \\
(0.026)\end{array}$ & $\begin{array}{c}0.012 \\
(0.026)\end{array}$ & $\begin{array}{c}0.000 \\
(0.026)\end{array}$ & $\begin{array}{c}0.053^{* *} \\
(0.026)\end{array}$ & $\begin{array}{c}0.030 \\
(0.024)\end{array}$ \\
\hline NVQ level 2 & $\begin{array}{l}0.119^{* * *} \\
(0.020)\end{array}$ & $\begin{array}{c}0.022 \\
(0.020)\end{array}$ & $\begin{array}{c}0.038^{*} \\
(0.020)\end{array}$ & $\begin{array}{l}0.157^{* * *} \\
(0.020)\end{array}$ & $\begin{array}{c}0.027 \\
(0.019)\end{array}$ \\
\hline NVQ level 3 & $\begin{array}{l}0.182^{* * * *} \\
(0.023)\end{array}$ & $\begin{array}{l}0.064^{* * *} \\
(0.023)\end{array}$ & $\begin{array}{l}0.050^{* *} \\
(0.022)\end{array}$ & $\begin{array}{l}0.218^{* * *} \\
(0.022)\end{array}$ & $\begin{array}{l}0.069^{* * *} \\
(0.021)\end{array}$ \\
\hline NVQ level 4 & $\begin{array}{l}0.241^{* * *} \\
(0.022)\end{array}$ & $\begin{array}{l}0.080^{* * *} \\
(0.022)\end{array}$ & $\begin{array}{c}0.075^{* * *} \\
(0.021)\end{array}$ & $\begin{array}{l}0.287^{* * *} \\
(0.021)\end{array}$ & $\begin{array}{l}0.094^{* * *} \\
(0.020)\end{array}$ \\
\hline NVQ level 5 & $\begin{array}{l}0.242^{* * *} \\
(0.033)\end{array}$ & $\begin{array}{c}0.021 \\
(0.034)\end{array}$ & $\begin{array}{l}0.114^{* * *} \\
(0.033)\end{array}$ & $\begin{array}{l}0.241^{* * *} \\
(0.034)\end{array}$ & $\begin{array}{l}0.138^{* * *} \\
(0.029)\end{array}$ \\
\hline \multicolumn{6}{|l|}{ Ethnicity } \\
\hline Mixed & $\begin{array}{c}0.043 \\
(0.058)\end{array}$ & $\begin{array}{c}-0.052 \\
(0.063)\end{array}$ & $\begin{array}{l}-0.048 \\
(0.059)\end{array}$ & $\begin{array}{c}0.024 \\
(0.053)\end{array}$ & $\begin{array}{l}-0.127^{* *} \\
(0.062)\end{array}$ \\
\hline Indian & $\begin{array}{c}-0.175^{* * *} \\
(0.038)\end{array}$ & $\begin{array}{l}0.121^{* * *} \\
(0.035)\end{array}$ & $\begin{array}{c}-0.053 \\
(0.040)\end{array}$ & $\begin{array}{l}-0.123^{* * *} \\
(0.037)\end{array}$ & $\begin{array}{c}-0.176^{* * *} \\
(0.039)\end{array}$ \\
\hline Pakistani and Bangladeshi & $\begin{array}{c}-0.161^{* * *} \\
(0.029)\end{array}$ & $\begin{array}{c}-0.028 \\
(0.028)\end{array}$ & $\begin{array}{l}-0.155^{* * *} \\
(0.029)\end{array}$ & $\begin{array}{c}-0.225^{* * *} \\
(0.034)\end{array}$ & $\begin{array}{c}-0.133^{* * *} \\
(0.028)\end{array}$ \\
\hline Black or Black British & $\begin{array}{c}-0.186^{* * *} \\
(0.036)\end{array}$ & $\begin{array}{c}-0.114^{* * *} \\
(0.036)\end{array}$ & $\begin{array}{c}-0.164^{* * *} \\
(0.036)\end{array}$ & $\begin{array}{c}-0.117^{* * *} \\
(0.034)\end{array}$ & $\begin{array}{c}-0.236^{* * *} \\
(0.037)\end{array}$ \\
\hline Other Ethnic group (inc Chinese, Other) & $\begin{array}{c}-0.022 \\
(0.050)\end{array}$ & $\begin{array}{c}-0.188^{* * *} \\
(0.047)\end{array}$ & $\begin{array}{c}-0.103^{* *} \\
(0.047)\end{array}$ & $\begin{array}{l}-0.121^{* * *} \\
(0.046)\end{array}$ & $\begin{array}{c}-0.069 \\
(0.045)\end{array}$ \\
\hline Outcome mean & 0.49 & 0.60 & 0.60 & 0.51 & 0.68 \\
\hline $\mathrm{N}$ & 11,117 & 11,119 & 11,117 & 11,119 & 11,119 \\
\hline
\end{tabular}

Note: $* * *$ and $* * *$ denote statistical significance it $10 \%, 5 \%$ and $1 \%$ respectively. The outcome in each column is the healthy behaviour indicated at the top of the column. See appendix Table A6(a) for how they were constructed. The effects reported are marginal effects obtained after estimating Equation 3 with the outcome in each column as the dependent variable and fixing the independent variables at their sample mean. All observations are adjusted for the probability of attrition and being sampled, see (Hansen et al., 2014). The omitted categories are income: highest quintile; parents' education: no qualifications; ethnicity: white. Female is an indicator of whether a child is female. Child overweight/obesity is defined using the the IOTF cutoffs (Table A1). The outcome mean represents the unconditional probability a child engages in each healthy behaviour. 
Table B11: Determinants of individual healthy behaviours at age 7

\begin{tabular}{|c|c|c|c|c|c|}
\hline & $\begin{array}{l}\text { Child has } \\
\text { regular meal times }\end{array}$ & $\begin{array}{c}\text { Fresh fruit/veg } \\
\text { once a day }\end{array}$ & $\begin{array}{l}\text { Plays physically } \\
\text { active games }\end{array}$ & $\begin{array}{l}\text { Child plays sport } \\
\text { once a week }\end{array}$ & $\begin{array}{l}\text { Does sport/exercise with } \\
\text { child once a week }\end{array}$ \\
\hline Child overweight or obese & $\begin{array}{l}0.005 \\
(0.015)\end{array}$ & $\begin{array}{c}0.011 \\
(0.015)\end{array}$ & $\begin{array}{l}-0.003 \\
(0.007)\end{array}$ & $\begin{array}{l}-0.000 \\
(0.015)\end{array}$ & $\begin{array}{l}-0.029^{* * *} \\
(0.008)\end{array}$ \\
\hline Main parent overweight & $\begin{array}{l}-0.031^{* *} \\
(0.013)\end{array}$ & $\begin{array}{l}-0.048^{* * *} \\
(0.014)\end{array}$ & $\begin{array}{l}-0.015^{* *} \\
(0.007)\end{array}$ & $\begin{array}{l}-0.036^{* * *} \\
(0.013)\end{array}$ & $\begin{array}{l}-0.017^{* * *} \\
(0.007)\end{array}$ \\
\hline Main parent obese/morbidly obese & $\begin{array}{l}-0.058^{* * *} \\
(0.017)\end{array}$ & $\begin{array}{l}-0.114^{* * *} \\
(0.017)\end{array}$ & $\begin{array}{l}-0.003 \\
(0.008)\end{array}$ & $\begin{array}{l}-0.070^{* * *} \\
(0.016)\end{array}$ & $\begin{array}{l}-0.010 \\
(0.007)\end{array}$ \\
\hline \multicolumn{6}{|l|}{ Equivalised household income quintiles } \\
\hline Lowest quintile & $\begin{array}{l}-0.077^{* * *} \\
(0.022)\end{array}$ & $\begin{array}{l}-0.001 \\
(0.022)\end{array}$ & $\begin{array}{l}-0.034^{* * *} \\
(0.009)\end{array}$ & $\begin{array}{c}0.012 \\
(0.022)\end{array}$ & $\begin{array}{l}-0.050^{* * *} \\
(0.010)\end{array}$ \\
\hline Second quintile & $\begin{array}{l}-0.074^{* * *} \\
(0.020)\end{array}$ & $\begin{array}{l}-0.033 \\
(0.020)\end{array}$ & $\begin{array}{l}-0.024^{* *} \\
(0.009)\end{array}$ & $\begin{array}{c}-0.043^{* *} \\
(0.020)\end{array}$ & $\begin{array}{l}-0.040^{* * *} \\
(0.009)\end{array}$ \\
\hline Third quintile & $\begin{array}{l}-0.065^{* * *} \\
(0.018)\end{array}$ & $\begin{array}{l}-0.041^{* *} \\
(0.018)\end{array}$ & $\begin{array}{l}-0.011 \\
(0.008)\end{array}$ & $\begin{array}{l}-0.022 \\
(0.018)\end{array}$ & $\begin{array}{l}-0.021^{* * *} \\
(0.007)\end{array}$ \\
\hline Fourth quintile & $\begin{array}{l}-0.025 \\
(0.017)\end{array}$ & $\begin{array}{r}-0.031^{*} \\
(0.017)\end{array}$ & $\begin{array}{l}-0.011 \\
(0.008)\end{array}$ & $\begin{array}{l}-0.016 \\
(0.017)\end{array}$ & $\begin{array}{r}-0.013^{*} \\
(0.007)\end{array}$ \\
\hline Female & $\begin{array}{l}0.045^{* * *} \\
(0.012)\end{array}$ & $\begin{array}{l}-0.038^{* * *} \\
(0.012)\end{array}$ & $\begin{array}{c}0.005 \\
(0.005)\end{array}$ & $\begin{array}{l}-0.040^{* * *} \\
(0.012)\end{array}$ & $\begin{array}{l}-0.017^{* * *} \\
(0.006)\end{array}$ \\
\hline Child long-term illness & $\begin{array}{c}0.012 \\
(0.016)\end{array}$ & $\begin{array}{c}0.003 \\
(0.016)\end{array}$ & $\begin{array}{l}-0.023^{* * *} \\
(0.009)\end{array}$ & $\begin{array}{c}0.002 \\
(0.016)\end{array}$ & $\begin{array}{c}0.003 \\
(0.007)\end{array}$ \\
\hline Health conditions & $\begin{array}{l}-0.001 \\
(0.005)\end{array}$ & $\begin{array}{l}-0.002 \\
(0.005)\end{array}$ & $\begin{array}{l}0.006^{* *} \\
(0.002)\end{array}$ & $\begin{array}{r}0.009^{*} \\
(0.005)\end{array}$ & $\begin{array}{l}-0.002 \\
(0.002)\end{array}$ \\
\hline Main parent long-term illness & $\begin{array}{l}-0.004 \\
(0.014)\end{array}$ & $\begin{array}{l}-0.036^{* *} \\
(0.014)\end{array}$ & $\begin{array}{r}-0.011^{*} \\
(0.007)\end{array}$ & $\begin{array}{c}0.003 \\
(0.014)\end{array}$ & $\begin{array}{r}-0.012^{*} \\
(0.007)\end{array}$ \\
\hline No. of siblings & $\begin{array}{c}0.009 \\
(0.006)\end{array}$ & $\begin{array}{l}-0.023^{* * *} \\
(0.006)\end{array}$ & $\begin{array}{l}0.017^{* * *} \\
(0.003)\end{array}$ & $\begin{array}{l}-0.004 \\
(0.006)\end{array}$ & $\begin{array}{l}0.007^{* * *} \\
(0.002)\end{array}$ \\
\hline Birthweight & $\begin{array}{l}0.035^{* * *} \\
(0.010)\end{array}$ & $\begin{array}{l}-0.021^{*} \\
(0.011)\end{array}$ & $\begin{array}{l}0.010^{* *} \\
(0.004)\end{array}$ & $\begin{array}{c}-0.015 \\
(0.011)\end{array}$ & $\begin{array}{l}0.011^{* *} \\
(0.004)\end{array}$ \\
\hline Weight gain 9 months -3 (kg) & $\begin{array}{c}0.006 \\
(0.005)\end{array}$ & $\begin{array}{c}0.002 \\
(0.005)\end{array}$ & $\begin{array}{l}-0.001 \\
(0.002)\end{array}$ & $\begin{array}{c}0.001 \\
(0.005)\end{array}$ & $\begin{array}{l}0.004^{* *} \\
(0.002)\end{array}$ \\
\hline \multicolumn{6}{|l|}{ Main parent's education } \\
\hline NVQ level 1 & $\begin{array}{c}0.011 \\
(0.028)\end{array}$ & $\begin{array}{c}0.026 \\
(0.028)\end{array}$ & $\begin{array}{c}0.017 \\
(0.014)\end{array}$ & $\begin{array}{l}-0.000 \\
(0.028)\end{array}$ & $\begin{array}{l}0.028^{* *} \\
(0.014)\end{array}$ \\
\hline NVQ level 2 & $\begin{array}{l}0.099^{* * *} \\
(0.022)\end{array}$ & $\begin{array}{c}0.034 \\
(0.022)\end{array}$ & $\begin{array}{l}0.038^{* * *} \\
(0.010)\end{array}$ & $\begin{array}{l}-0.020 \\
(0.022)\end{array}$ & $\begin{array}{l}0.037^{* * *} \\
(0.011)\end{array}$ \\
\hline NVQ level 3 & $\begin{array}{l}0.181^{* * *} \\
(0.025)\end{array}$ & $\begin{array}{l}0.052^{* *} \\
(0.025)\end{array}$ & $\begin{array}{l}0.024^{* *} \\
(0.012)\end{array}$ & $\begin{array}{l}-0.016 \\
(0.025)\end{array}$ & $\begin{array}{l}0.046^{* * *} \\
(0.012)\end{array}$ \\
\hline NVQ level 4 & $\begin{array}{l}0.229^{* * *} \\
(0.024)\end{array}$ & $\begin{array}{c}0.039^{*} \\
(0.024)\end{array}$ & $\begin{array}{l}0.040^{* * *} \\
(0.011)\end{array}$ & $\begin{array}{l}-0.022 \\
(0.023)\end{array}$ & $\begin{array}{l}0.057^{* * *} \\
(0.012)\end{array}$ \\
\hline NVQ level 5 & $\begin{array}{l}0.294^{* * *} \\
(0.034)\end{array}$ & $\begin{array}{c}0.058 \\
(0.036)\end{array}$ & $\begin{array}{l}0.045^{* *} \\
(0.016)\end{array}$ & $\begin{array}{c}-0.079^{* *} \\
(0.034)\end{array}$ & $\begin{array}{l}0.073^{* * *} \\
(0.015)\end{array}$ \\
\hline \multicolumn{6}{|l|}{ Ethnicity } \\
\hline Mixed & $\begin{array}{c}0.006 \\
(0.071)\end{array}$ & $\begin{array}{l}-0.108 \\
(0.072)\end{array}$ & $\begin{array}{l}-0.074^{* *} \\
(0.045)\end{array}$ & $\begin{array}{l}-0.202^{* * *} \\
(0.064)\end{array}$ & $\begin{array}{c}0.009 \\
(0.030)\end{array}$ \\
\hline Indian & $\begin{array}{c}-0.076^{*} \\
(0.040)\end{array}$ & $\begin{array}{l}-0.027 \\
(0.041)\end{array}$ & $\begin{array}{c}-0.044^{* *} \\
(0.022)\end{array}$ & $\begin{array}{c}-0.124^{* * *} \\
(0.040)\end{array}$ & $\begin{array}{l}-0.000 \\
(0.021)\end{array}$ \\
\hline Pakistani and Bangladeshi & $\begin{array}{c}-0.071^{* *} \\
(0.030)\end{array}$ & $\begin{array}{l}-0.099^{* * *} \\
(0.031)\end{array}$ & $\begin{array}{l}-0.082^{* * *} \\
(0.018)\end{array}$ & $\begin{array}{c}-0.227^{* * *} \\
(0.025)\end{array}$ & $\begin{array}{l}-0.001 \\
(0.013)\end{array}$ \\
\hline Black or Black British & $\begin{array}{c}-0.174^{* * *} \\
(0.042)\end{array}$ & $\begin{array}{c}-0.149^{* * *} \\
(0.040)\end{array}$ & $\begin{array}{c}-0.104^{* * *} \\
(0.030)\end{array}$ & $\begin{array}{c}-0.205^{* * *} \\
(0.033)\end{array}$ & $\begin{array}{c}0.008 \\
(0.015)\end{array}$ \\
\hline Other Ethnic group (inc Chinese,Other) & $\begin{array}{l}-0.077 \\
(0.055)\end{array}$ & $\begin{array}{c}-0.127^{* *} \\
(0.049)\end{array}$ & $\begin{array}{l}-0.031 \\
(0.026)\end{array}$ & $\begin{array}{l}-0.142^{* * *} \\
(0.049)\end{array}$ & $\begin{array}{l}-0.006 \\
(0.023)\end{array}$ \\
\hline $\begin{array}{l}\text { Outcome mean } \\
\mathrm{N}\end{array}$ & $\begin{array}{c}0.50 \\
10,183\end{array}$ & $\begin{array}{c}0.50 \\
10,185\end{array}$ & $\begin{array}{c}0.93 \\
10,186\end{array}$ & $\begin{array}{c}0.41 \\
10,185\end{array}$ & $\begin{array}{c}0.93 \\
10,181\end{array}$ \\
\hline
\end{tabular}

Note: $* * *$ and $* * *$ denote statistical significance it $10 \%, 5 \%$ and $1 \%$ respectively. The outcome in each column is the healthy behaviour indicated at the top of the column. See appendix Table A6(a) for how they were constructed. The effects reported are marginal effects obtained after estimating Equation 3 with the outcome in each column as the dependent variable and fixing the independent variables at their sample mean. All observations are adjusted for the probability of attrition and being sampled, see (Hansen et al., 2014). The omitted categories are income: highest quintile; parents' education: no qualifications; ethnicity: white. Female is an indicator of whether a child is female. Child overweight/obesity is defined using the the IOTF cutoffs (Table A1). The outcome mean represents the unconditional probability a child engages in each healthy behaviour. 
Table B12: Determinants of individual healthy behaviours at age 11

\begin{tabular}{|c|c|c|c|c|c|c|c|}
\hline & $\begin{array}{c}\text { Fresh fruit/veg } \\
\text { once a day }\end{array}$ & $\begin{array}{l}\text { Plays physically } \\
\text { active games }\end{array}$ & $\begin{array}{l}\text { Child play sport } \\
\text { once a week }\end{array}$ & $\begin{array}{l}\text { Does sport/exercise with } \\
\text { child once a week }\end{array}$ & $\begin{array}{l}\text { Has breakfast } \\
\text { every day }\end{array}$ & $\begin{array}{l}\text { Drinks sweetened drinks } \\
\text { less than once a day }\end{array}$ & $\begin{array}{l}\text { Drinks artificially } \\
\text { sweetened drinks } \\
\text { less than once a day }\end{array}$ \\
\hline Child overweight or obese & $\begin{array}{l}-0.014 \\
(0.015)\end{array}$ & $\begin{array}{l}-0.056^{* * *} \\
(0.015)\end{array}$ & $\begin{array}{l}-0.028^{* * *} \\
(0.009)\end{array}$ & $\begin{array}{l}-0.003 \\
(0.009)\end{array}$ & $\begin{array}{l}-0.023^{* *} \\
(0.011)\end{array}$ & $\begin{array}{l}-0.011 \\
(0.014)\end{array}$ & $\begin{array}{l}-0.042^{* * *} \\
(0.015)\end{array}$ \\
\hline Main parent overweight & $\begin{array}{l}-0.033^{* *} \\
(0.015)\end{array}$ & $\begin{array}{l}-0.012 \\
(0.015)\end{array}$ & $\begin{array}{c}-0.002 \\
(0.009)\end{array}$ & $\begin{array}{l}-0.007 \\
(0.009)\end{array}$ & $\begin{array}{l}-0.006 \\
(0.011)\end{array}$ & $\begin{array}{c}0.022 \\
(0.014)\end{array}$ & $\begin{array}{l}-0.054^{* * *} \\
(0.015)\end{array}$ \\
\hline Main parent obese/morbidly obese & $\begin{array}{c}0.004 \\
(0.019)\end{array}$ & $\begin{array}{l}-0.038^{* *} \\
(0.018)\end{array}$ & $\begin{array}{l}-0.016 \\
(0.010)\end{array}$ & $\begin{array}{l}-0.002 \\
(0.010)\end{array}$ & $\begin{array}{c}0.009 \\
(0.012)\end{array}$ & $\begin{array}{c}0.011 \\
(0.016)\end{array}$ & $\begin{array}{l}-0.074^{* * *} \\
(0.018)\end{array}$ \\
\hline \multicolumn{8}{|l|}{ Equivalised household income quintiles } \\
\hline Lowest quintile & $\begin{array}{l}-0.168^{* * *} \\
(0.031)\end{array}$ & $\begin{array}{l}-0.215^{* * *} \\
(0.032)\end{array}$ & $\begin{array}{l}-0.022 \\
(0.018)\end{array}$ & $\begin{array}{l}-0.004 \\
(0.017)\end{array}$ & $\begin{array}{l}-0.133^{* * *} \\
(0.023)\end{array}$ & $\begin{array}{l}-0.108^{* * *} \\
(0.030)\end{array}$ & $\begin{array}{l}-0.114^{* * *} \\
(0.030)\end{array}$ \\
\hline Second quintile & $\begin{array}{l}-0.124^{* * *} \\
(0.025)\end{array}$ & $\begin{array}{l}-0.191^{* * *} \\
(0.025)\end{array}$ & $\begin{array}{l}-0.023 \\
(0.014)\end{array}$ & $\begin{array}{l}-0.012 \\
(0.015)\end{array}$ & $\begin{array}{l}-0.101^{* * *} \\
(0.016)\end{array}$ & $\begin{array}{r}-0.040^{*} \\
(0.023)\end{array}$ & $\begin{array}{l}-0.112^{* * *} \\
(0.024)\end{array}$ \\
\hline Third quintile & $\begin{array}{l}-0.107^{* * *} \\
(0.022)\end{array}$ & $\begin{array}{l}-0.078^{* * *} \\
(0.021)\end{array}$ & $\begin{array}{c}0.001 \\
(0.012)\end{array}$ & $\begin{array}{l}-0.011 \\
(0.012)\end{array}$ & $\begin{array}{l}-0.045^{* * *} \\
(0.013)\end{array}$ & $\begin{array}{r}-0.037^{*} \\
(0.020)\end{array}$ & $\begin{array}{l}-0.116^{* * *} \\
(0.021)\end{array}$ \\
\hline Fourth quintile & $\begin{array}{l}-0.053^{* * *} \\
(0.019)\end{array}$ & $\begin{array}{l}-0.031 \\
(0.019)\end{array}$ & $\begin{array}{l}-0.005 \\
(0.012)\end{array}$ & $\begin{array}{l}-0.007 \\
(0.011)\end{array}$ & $\begin{array}{l}-0.024^{* *} \\
(0.011)\end{array}$ & $\begin{array}{l}-0.003 \\
(0.018)\end{array}$ & $\begin{array}{l}-0.040^{* *} \\
(0.018)\end{array}$ \\
\hline Female & $\begin{array}{l}0.052^{* * *} \\
(0.013)\end{array}$ & $\begin{array}{l}-0.072^{* * *} \\
(0.013)\end{array}$ & $\begin{array}{l}-0.020^{* * *} \\
(0.008)\end{array}$ & $\begin{array}{c}0.010 \\
(0.008)\end{array}$ & $\begin{array}{l}-0.037^{* * *} \\
(0.009)\end{array}$ & $\begin{array}{l}0.028^{* *} \\
(0.012)\end{array}$ & $\begin{array}{c}0.013 \\
(0.013)\end{array}$ \\
\hline Child long-term illness & $\begin{array}{c}0.021 \\
(0.021)\end{array}$ & $\begin{array}{c}-0.066^{* * *} \\
(0.021)\end{array}$ & $\begin{array}{l}-0.053^{* * *} \\
(0.014)\end{array}$ & $\begin{array}{l}0.036^{\text {**** }} \\
(0.013)\end{array}$ & $\begin{array}{c}0.015 \\
(0.013)\end{array}$ & $\begin{array}{l}-0.018 \\
(0.019)\end{array}$ & $\begin{array}{l}-0.021 \\
(0.020)\end{array}$ \\
\hline Health conditions & $\begin{array}{c}-0.009 \\
(0.005)\end{array}$ & $\begin{array}{l}-0.001 \\
(0.005)\end{array}$ & $\begin{array}{l}0.005^{*} \\
(0.003)\end{array}$ & $\begin{array}{c}-0.002 \\
(0.003)\end{array}$ & $\begin{array}{c}-0.004 \\
(0.004)\end{array}$ & $\begin{array}{c}-0.002 \\
(0.005)\end{array}$ & $\begin{array}{c}-0.002 \\
(0.005)\end{array}$ \\
\hline Main parent long-term illness & $\begin{array}{c}-0.001 \\
(0.016)\end{array}$ & $\begin{array}{c}-0.028^{*} \\
(0.016)\end{array}$ & $\begin{array}{r}-0.018^{*} \\
(0.010)\end{array}$ & $\begin{array}{c}-0.013 \\
(0.009)\end{array}$ & $\begin{array}{c}-0.026^{* *} \\
(0.011)\end{array}$ & $\begin{array}{c}0.002 \\
(0.015)\end{array}$ & $\begin{array}{c}0.013 \\
(0.015)\end{array}$ \\
\hline No. of siblings & $\begin{array}{l}0.017^{* *} \\
(0.007)\end{array}$ & $\begin{array}{c}0.003 \\
(0.007)\end{array}$ & $\begin{array}{c}0.006 \\
(0.004)\end{array}$ & $\begin{array}{l}-0.005 \\
(0.004)\end{array}$ & $\begin{array}{l}0.012^{* *} \\
(0.005)\end{array}$ & $\begin{array}{c}0.003 \\
(0.007)\end{array}$ & $\begin{array}{c}0.001 \\
(0.007)\end{array}$ \\
\hline Birthweight & $\begin{array}{c}0.011 \\
(0.011)\end{array}$ & $\begin{array}{l}0.029^{* *} \\
(0.011)\end{array}$ & $\begin{array}{c}-0.010 \\
(0.007)\end{array}$ & $\begin{array}{l}-0.016^{* *} \\
(0.006)\end{array}$ & $\begin{array}{c}-0.003 \\
(0.008)\end{array}$ & $\begin{array}{c}0.005 \\
(0.011)\end{array}$ & $\begin{array}{c}-0.012 \\
(0.011)\end{array}$ \\
\hline Weight gain 9 months- 3 (kg) & $\begin{array}{l}0.008 \\
(0.005)\end{array}$ & $\begin{array}{c}-0.001 \\
(0.006)\end{array}$ & $\begin{array}{c}0.001 \\
(0.003)\end{array}$ & $\begin{array}{c}-0.004 \\
(0.003)\end{array}$ & $\begin{array}{l}0.012^{* * *} \\
(0.004)\end{array}$ & $\begin{array}{c}0.007 \\
(0.005)\end{array}$ & $\begin{array}{c}-0.004 \\
(0.005)\end{array}$ \\
\hline \multicolumn{8}{|l|}{ Main parent's education } \\
\hline NVQ level 1 & $\begin{array}{l}-0.026 \\
(0.033)\end{array}$ & $\begin{array}{c}0.031 \\
(0.034)\end{array}$ & $\begin{array}{c}0.033^{*} \\
(0.018)\end{array}$ & $\begin{array}{l}-0.024 \\
(0.018)\end{array}$ & $\begin{array}{c}0.017 \\
(0.023)\end{array}$ & $\begin{array}{c}0.024 \\
(0.031)\end{array}$ & $\begin{array}{l}-0.066^{* *} \\
(0.032)\end{array}$ \\
\hline NVQ level 2 & $\begin{array}{c}0.050^{*} \\
(0.027)\end{array}$ & $\begin{array}{l}0.068^{* *} \\
(0.027)\end{array}$ & $\begin{array}{c}0.024^{*} \\
(0.015)\end{array}$ & $\begin{array}{l}-0.007 \\
(0.016)\end{array}$ & $\begin{array}{l}0.036^{* *} \\
(0.018)\end{array}$ & $\begin{array}{c}0.038 \\
(0.024)\end{array}$ & $\begin{array}{c}-0.048^{*} \\
(0.025)\end{array}$ \\
\hline NVQ level 3 & $\begin{array}{l}0.077^{* *} \\
(0.030)\end{array}$ & $\begin{array}{l}0.058^{*} \\
(0.030)\end{array}$ & $\begin{array}{l}0.036^{* *} \\
(0.016)\end{array}$ & $\begin{array}{c}-0.011 \\
(0.018)\end{array}$ & $\begin{array}{l}0.049^{* *} \\
(0.021)\end{array}$ & $\begin{array}{l}0.064^{* *} \\
(0.027)\end{array}$ & $\begin{array}{c}0.001 \\
(0.028)\end{array}$ \\
\hline NVQ level 4 & $\begin{array}{l}0.138^{* * *} \\
(0.029)\end{array}$ & $\begin{array}{l}0.134^{* * *} \\
(0.029)\end{array}$ & $\begin{array}{l}0.044^{* * *} \\
(0.016)\end{array}$ & $\begin{array}{l}-0.020 \\
(0.017)\end{array}$ & $\begin{array}{l}0.064^{* * *} \\
(0.021)\end{array}$ & $\begin{array}{l}0.101^{* * * *} \\
(0.027)\end{array}$ & $\begin{array}{l}0.051^{*} \\
(0.028)\end{array}$ \\
\hline NVQ level 5 & $\begin{array}{l}0.158^{* * *} \\
(0.042)\end{array}$ & $\begin{array}{l}0.180^{* * *} \\
(0.041)\end{array}$ & $\begin{array}{l}0.061^{* *} \\
(0.021)\end{array}$ & $\begin{array}{l}-0.050^{* *} \\
(0.020)\end{array}$ & $\begin{array}{l}0.129^{* * *} \\
(0.022)\end{array}$ & $\begin{array}{l}0.181^{* * *} \\
(0.036)\end{array}$ & $\begin{array}{l}0.181^{* * * *} \\
(0.037)\end{array}$ \\
\hline \multicolumn{8}{|l|}{ Ethnicity } \\
\hline Mixed & $\begin{array}{c}0.058 \\
(0.044)\end{array}$ & $\begin{array}{c}-0.102^{* *} \\
(0.042)\end{array}$ & $\begin{array}{c}-0.035 \\
(0.026)\end{array}$ & $\begin{array}{l}-0.055^{* * *} \\
(0.012)\end{array}$ & $\begin{array}{c}-0.002 \\
(0.030)\end{array}$ & $\begin{array}{c}0.055 \\
(0.036)\end{array}$ & $\begin{array}{c}0.070 \\
(0.041)\end{array}$ \\
\hline Indian & $\begin{array}{c}-0.039 \\
(0.044)\end{array}$ & $\begin{array}{r}-0.108^{*} \\
(0.056)\end{array}$ & $\begin{array}{c}-0.120^{* * *} \\
(0.037)\end{array}$ & $\begin{array}{c}0.025 \\
(0.034)\end{array}$ & $\begin{array}{c}0.017 \\
(0.037)\end{array}$ & $\begin{array}{c}-0.039 \\
(0.048)\end{array}$ & $\begin{array}{l}0.168^{* * *} \\
(0.043)\end{array}$ \\
\hline Pakistani and Bangladeshi & $\begin{array}{l}-0.024 \\
(0.038)\end{array}$ & $\begin{array}{c}-0.198^{* * *} \\
(0.038)\end{array}$ & $\begin{array}{l}-0.091^{* * *} \\
(0.026)\end{array}$ & $\begin{array}{l}-0.009 \\
(0.019)\end{array}$ & $\begin{array}{l}0.059^{* * * *} \\
(0.016)\end{array}$ & $\begin{array}{c}-0.066^{* *} \\
(0.034)\end{array}$ & $\begin{array}{l}0.214^{* * *} \\
(0.027)\end{array}$ \\
\hline Black or Black British & $\begin{array}{l}0.105^{* *} \\
(0.045)\end{array}$ & $\begin{array}{l}-0.091^{* *} \\
(0.041)\end{array}$ & $\begin{array}{l}-0.078^{* * *} \\
(0.028)\end{array}$ & $\begin{array}{c}-0.034 \\
(0.019)\end{array}$ & $\begin{array}{c}-0.023 \\
(0.031)\end{array}$ & $\begin{array}{l}-0.008 \\
(0.042)\end{array}$ & $\begin{array}{l}0.248^{* * *} \\
(0.032)\end{array}$ \\
\hline Other Ethnic group (inc Chinese,Other) & $\begin{array}{c}0.080 \\
(0.072)\end{array}$ & $\begin{array}{l}-0.083 \\
(0.064)\end{array}$ & $\begin{array}{c}-0.136^{* * *} \\
(0.061)\end{array}$ & $\begin{array}{c}0.012 \\
(0.042)\end{array}$ & $\begin{array}{c}0.060 \\
(0.033)\end{array}$ & $\begin{array}{c}0.048 \\
(0.064)\end{array}$ & $\begin{array}{l}0.195^{* *} \\
(0.063)\end{array}$ \\
\hline $\begin{array}{l}\text { Outcome mean } \\
\mathrm{N}\end{array}$ & $\begin{array}{l}0.42 \\
8,419\end{array}$ & $\begin{array}{l}0.52 \\
8,426\end{array}$ & $\begin{array}{l}0.90 \\
8,422\end{array}$ & $\begin{array}{l}0.09 \\
8,425\end{array}$ & $\begin{array}{l}0.87 \\
8,422\end{array}$ & $\begin{array}{l}0.69 \\
8,425\end{array}$ & $\begin{array}{l}0.60 \\
8,423\end{array}$ \\
\hline
\end{tabular}

Note: $* * *$ and $* * *$ denote statistical significance it $10 \%, 5 \%$ and $1 \%$ respectively. The outcome in each column is the healthy behaviour indicated at the top of the column. See appendix Table A6(a) for how they were constructed. The effects reported are marginal effects obtained after estimating Equation 3 with the outcome in each column as the dependent variable and fixing the independent variables at their sample mean. All observations are adjusted for the probability of attrition and being sampled, see (Hansen et al., 2014). The omitted categories are income: highest quintile; parents' education: no qualifications; ethnicity: white. Female is an indicator of whether a child is female. Child overweight/obesity is defined using the the IOTF cutoffs (Table A1). The outcome mean represents the unconditional probability a child engages in each healthy behaviour. 
Table B13: Determinants of individual healthy behaviours at age 14

\begin{tabular}{|c|c|c|c|c|c|}
\hline & $\begin{array}{c}\text { Fresh fruit/veg } \\
\text { once a day }\end{array}$ & $\begin{array}{c}\text { Has breakfast } \\
\text { every day }\end{array}$ & $\begin{array}{l}\text { Drinks sweetened drinks } \\
\text { less than once a day }\end{array}$ & $\begin{array}{l}\text { Drinks artificially } \\
\text { sweetened drinks } \\
\text { less than once a day }\end{array}$ & $\begin{array}{l}\text { Has fast food } \\
\text { less than once a month }\end{array}$ \\
\hline Child overweight or obese & $\begin{array}{c}0.011 \\
(0.017)\end{array}$ & $\begin{array}{l}-0.078^{* * *} \\
(0.018)\end{array}$ & $\begin{array}{c}0.013 \\
(0.015)\end{array}$ & $\begin{array}{l}-0.067^{* * *} \\
(0.015)\end{array}$ & $\begin{array}{r}0.032^{*} \\
(0.018)\end{array}$ \\
\hline Main parent overweight & $\begin{array}{c}-0.033^{* *} \\
(0.015)\end{array}$ & $\begin{array}{l}-0.055^{* * *} \\
(0.017)\end{array}$ & $\begin{array}{l}-0.043^{* * *} \\
(0.015)\end{array}$ & $\begin{array}{l}-0.061^{* * *} \\
(0.014)\end{array}$ & $\begin{array}{l}-0.025 \\
(0.016)\end{array}$ \\
\hline Main parent obese/Morbidly obese & $\begin{array}{l}-0.065^{* * *} \\
(0.018)\end{array}$ & $\begin{array}{l}-0.079^{* * *} \\
(0.020)\end{array}$ & $\begin{array}{l}-0.034^{* *} \\
(0.017)\end{array}$ & $\begin{array}{l}-0.038^{* *} \\
(0.015)\end{array}$ & $\begin{array}{l}-0.057^{* * *} \\
(0.018)\end{array}$ \\
\hline \multicolumn{6}{|l|}{ Equivalised household income quintiles } \\
\hline Lowest quintile & $\begin{array}{l}-0.163^{* * *} \\
(0.029)\end{array}$ & $\begin{array}{l}-0.257^{* * *} \\
(0.034)\end{array}$ & $\begin{array}{l}-0.189^{* * *} \\
(0.031)\end{array}$ & $\begin{array}{l}-0.071^{* *} \\
(0.029)\end{array}$ & $\begin{array}{l}-0.086^{* *} \\
(0.034)\end{array}$ \\
\hline Second quintile & $\begin{array}{l}-0.121^{* * *} \\
(0.025)\end{array}$ & $\begin{array}{l}-0.210^{* * *} \\
(0.026)\end{array}$ & $\begin{array}{l}-0.119^{* * *} \\
(0.023)\end{array}$ & $\begin{array}{l}-0.062^{* * *} \\
(0.022)\end{array}$ & $\begin{array}{l}-0.112^{* * *} \\
(0.024)\end{array}$ \\
\hline Third quintile & $\begin{array}{l}-0.102^{* * *} \\
(0.020)\end{array}$ & $\begin{array}{l}-0.153^{* * *} \\
(0.022)\end{array}$ & $\begin{array}{l}-0.067^{* * *} \\
(0.018)\end{array}$ & $\begin{array}{l}-0.004 \\
(0.017)\end{array}$ & $\begin{array}{l}-0.092^{* * *} \\
(0.020)\end{array}$ \\
\hline Fourth quintile & $\begin{array}{r}-0.031^{*} \\
(0.018)\end{array}$ & $\begin{array}{l}-0.084^{* * *} \\
(0.019)\end{array}$ & $\begin{array}{c}-0.028^{*} \\
(0.016)\end{array}$ & $\begin{array}{c}-0.033^{* *} \\
(0.015)\end{array}$ & $\begin{array}{c}-0.031^{*} \\
(0.018)\end{array}$ \\
\hline Female & $\begin{array}{c}0.013 \\
(0.013)\end{array}$ & $\begin{array}{l}-0.160^{* * *} \\
(0.015)\end{array}$ & $\begin{array}{l}0.054^{* * *} \\
(0.013)\end{array}$ & $\begin{array}{l}0.036^{* * *} \\
(0.012)\end{array}$ & $\begin{array}{c}0.016 \\
(0.014)\end{array}$ \\
\hline Child long-term illness & $\begin{array}{c}0.001 \\
(0.027)\end{array}$ & $\begin{array}{l}-0.026 \\
(0.028)\end{array}$ & $\begin{array}{c}0.031 \\
(0.022)\end{array}$ & $\begin{array}{c}-0.024 \\
(0.022)\end{array}$ & $\begin{array}{l}-0.021 \\
(0.025)\end{array}$ \\
\hline Health conditions & $\begin{array}{c}0.001 \\
(0.015)\end{array}$ & $\begin{array}{c}0.024 \\
(0.015)\end{array}$ & $\begin{array}{c}-0.014 \\
(0.011)\end{array}$ & $\begin{array}{c}-0.015 \\
(0.010)\end{array}$ & $\begin{array}{l}0.032^{* *} \\
(0.014)\end{array}$ \\
\hline Main parent long-term illness & $\begin{array}{c}-0.032^{* *} \\
(0.016)\end{array}$ & $\begin{array}{r}-0.029^{*} \\
(0.018)\end{array}$ & $\begin{array}{c}0.001 \\
(0.016)\end{array}$ & $\begin{array}{r}0.026^{*} \\
(0.014)\end{array}$ & $\begin{array}{c}0.012 \\
(0.017)\end{array}$ \\
\hline No. of siblings & $\begin{array}{l}0.010 \\
(0.007)\end{array}$ & $\begin{array}{c}0.002 \\
(0.007)\end{array}$ & $\begin{array}{l}0.028^{* * *} \\
(0.007)\end{array}$ & $\begin{array}{l}0.024^{* * *} \\
(0.006)\end{array}$ & $\begin{array}{l}0.009 \\
(0.007)\end{array}$ \\
\hline Birthweight & $\begin{array}{c}0.004 \\
(0.012)\end{array}$ & $\begin{array}{c}0.029^{* *} \\
(0.013)\end{array}$ & $\begin{array}{l}0.040^{* * *} \\
(0.011)\end{array}$ & $\begin{array}{l}0.030^{* * *} \\
(0.010)\end{array}$ & $\begin{array}{c}-0.014 \\
(0.012)\end{array}$ \\
\hline Weight gain 9 months $-3(\mathrm{~kg})$ & $\begin{array}{c}0.000 \\
(0.006)\end{array}$ & $\begin{array}{c}0.013^{*} \\
(0.007)\end{array}$ & $\begin{array}{c}-0.008 \\
(0.005)\end{array}$ & $\begin{array}{c}0.008 \\
(0.005)\end{array}$ & $\begin{array}{c}-0.009 \\
(0.007)\end{array}$ \\
\hline \multicolumn{6}{|l|}{ Main parent's education } \\
\hline NVQ level 1 & $\begin{array}{c}0.016 \\
(0.032)\end{array}$ & $\begin{array}{c}0.001 \\
(0.038)\end{array}$ & $\begin{array}{c}-0.025 \\
(0.032)\end{array}$ & $\begin{array}{c}0.043 \\
(0.028)\end{array}$ & $\begin{array}{c}-0.002 \\
(0.039)\end{array}$ \\
\hline NVQ level 2 & $\begin{array}{l}0.062^{* *} \\
(0.025)\end{array}$ & $\begin{array}{l}-0.023 \\
(0.030)\end{array}$ & $\begin{array}{c}-0.008 \\
(0.025)\end{array}$ & $\begin{array}{l}-0.013 \\
(0.024)\end{array}$ & $\begin{array}{c}0.003 \\
(0.029)\end{array}$ \\
\hline NVQ level 3 & $\begin{array}{l}0.102^{* * *} \\
(0.029)\end{array}$ & $\begin{array}{c}0.016 \\
(0.033)\end{array}$ & $\begin{array}{c}0.060^{* * *} \\
(0.027)\end{array}$ & $\begin{array}{c}0.022 \\
(0.026)\end{array}$ & $\begin{array}{c}0.035 \\
(0.031)\end{array}$ \\
\hline NVQ level 4 & $\begin{array}{l}0.169^{* * *} \\
(0.027)\end{array}$ & $\begin{array}{l}0.054^{*} \\
(0.031)\end{array}$ & $\begin{array}{c}0.064^{* *} \\
(0.026)\end{array}$ & $\begin{array}{l}0.042^{*} \\
(0.025)\end{array}$ & $\begin{array}{l}0.100^{* * *} \\
(0.031)\end{array}$ \\
\hline NVQ level 5 & $\begin{array}{l}0.216^{* * *} \\
(0.040)\end{array}$ & $\begin{array}{c}0.092^{* *} \\
(0.043)\end{array}$ & $\begin{array}{l}0.108^{* * *} \\
(0.035)\end{array}$ & $\begin{array}{c}0.039 \\
(0.036)\end{array}$ & $\begin{array}{l}0.174^{* * *} \\
(0.043)\end{array}$ \\
\hline \multicolumn{6}{|l|}{ Ethnicity } \\
\hline Mixed & $\begin{array}{l}-0.141^{* *} \\
(0.054)\end{array}$ & $\begin{array}{c}0.106 \\
(0.092)\end{array}$ & $\begin{array}{r}-0.146^{*} \\
(0.094)\end{array}$ & $\begin{array}{l}-0.027 \\
(0.085)\end{array}$ & $\begin{array}{c}-0.071 \\
(0.069)\end{array}$ \\
\hline Indian & $\begin{array}{c}0.086^{* *} \\
(0.045)\end{array}$ & $\begin{array}{c}0.130^{* *} \\
(0.060)\end{array}$ & $\begin{array}{l}0.149^{* * *} \\
(0.025)\end{array}$ & $\begin{array}{c}0.057 \\
(0.031)\end{array}$ & $\begin{array}{c}0.019 \\
(0.084)\end{array}$ \\
\hline Pakistani and Bangladeshi & $\begin{array}{l}0.171^{* * *} \\
(0.046)\end{array}$ & $\begin{array}{l}0.157^{* * *} \\
(0.033)\end{array}$ & $\begin{array}{c}-0.007 \\
(0.035)\end{array}$ & $\begin{array}{c}0.019 \\
(0.027)\end{array}$ & $\begin{array}{c}-0.103^{* * *} \\
(0.034)\end{array}$ \\
\hline Black or Black British & $\begin{array}{c}-0.131^{* * *} \\
(0.035)\end{array}$ & $\begin{array}{c}-0.049 \\
(0.057)\end{array}$ & $\begin{array}{l}0.072^{*} \\
(0.035)\end{array}$ & $\begin{array}{l}0.088^{* * *} \\
(0.027)\end{array}$ & $\begin{array}{c}-0.023 \\
(0.065)\end{array}$ \\
\hline Other Ethnic group (inc Chinese,Other) & $\begin{array}{c}0.182^{* *} \\
(0.076)\end{array}$ & $\begin{array}{c}0.045 \\
(0.067)\end{array}$ & $\begin{array}{l}0.167^{* * *} \\
(0.031)\end{array}$ & $\begin{array}{c}0.055 \\
(0.058)\end{array}$ & $\begin{array}{c}-0.107^{* *} \\
(0.042)\end{array}$ \\
\hline Outcome mean & 0.31 & 0.53 & 0.76 & 0.80 & 0.27 \\
\hline $\mathrm{N}$ & 7,026 & 7,029 & 7,010 & 7,004 & 7,022 \\
\hline
\end{tabular}

Note: $* * *$ and $* * *$ denote statistical significance it $10 \%, 5 \%$ and $1 \%$ respectively. The outcome in each column is the healthy behaviour indicated at the top of the column. See appendix Table A6(a) for how they were constructed. The effects reported are marginal effects obtained after estimating Equation 3 with the outcome in each column as the dependent variable and fixing the independent variables at their sample mean. All observations are adjusted for the probability of attrition and being sampled, see (Hansen et al., 2014). The omitted categories are income: highest quintile; parents' education: no qualifications; ethnicity: white. Female is an indicator of whether a child is female. Child overweight/obesity is defined using the the IOTF cutoffs (Table A1). The outcome mean represents the unconditional probability a child engages in each healthy behaviour. 
B.3 Additional tables on healthy behaviour and children's weight across ages 
Table B14: Index of healthy behaviours and overweight in children across ages with full controls

\begin{tabular}{|c|c|c|c|c|c|c|}
\hline & \multirow[b]{2}{*}{$\begin{array}{c}\text { (1) } \\
\text { Age } 3\end{array}$} & \multirow[b]{2}{*}{$\begin{array}{l}\text { (2) } \\
\text { Age } 5\end{array}$} & \multirow[b]{2}{*}{$\begin{array}{c}\text { (3) } \\
\text { Age } 7\end{array}$} & \multirow[b]{2}{*}{$\begin{array}{c}(4) \\
\text { Age } 11\end{array}$} & \multicolumn{2}{|c|}{ (5)-(6) Age 14} \\
\hline & & & & & $\begin{array}{l}\text { Parental weight } \\
\text { constant }\end{array}$ & $\begin{array}{c}\text { Parental weight } \\
\text { predicted }\end{array}$ \\
\hline Healthy lifestyle & $\begin{array}{c}-0.003 \\
(0.008)\end{array}$ & $\begin{array}{c}0.006 \\
(0.008)\end{array}$ & $\begin{array}{l}-0.008 \\
(0.008)\end{array}$ & $\begin{array}{l}-0.028^{* *} \\
(0.011)\end{array}$ & $\begin{array}{l}-0.018 \\
(0.012)\end{array}$ & $\begin{array}{c}-0.019 \\
(0.012)\end{array}$ \\
\hline Main parent overweight & $\begin{array}{l}0.022^{* *} \\
(0.010)\end{array}$ & $\begin{array}{l}0.058^{* * *} \\
(0.009)\end{array}$ & $\begin{array}{l}0.061^{* * *} \\
(0.010)\end{array}$ & $\begin{array}{l}0.099^{* * * *} \\
(0.013)\end{array}$ & $\begin{array}{l}0.102^{* * *} \\
(0.014)\end{array}$ & $\begin{array}{l}0.072^{* * *} \\
(0.012)\end{array}$ \\
\hline Main parent obese/morbidly obese & $\begin{array}{l}0.061^{* * *} \\
(0.014)\end{array}$ & $\begin{array}{l}0.124^{* * *} \\
(0.014)\end{array}$ & $\begin{array}{l}0.093^{* * *} \\
(0.013)\end{array}$ & $\begin{array}{l}0.197^{* * * *} \\
(0.017)\end{array}$ & $\begin{array}{l}0.168^{* * *} \\
(0.018)\end{array}$ & $\begin{array}{l}0.169^{* * * *} \\
(0.017)\end{array}$ \\
\hline \multicolumn{7}{|l|}{ Income quintiles } \\
\hline Lowest quintile & $\begin{array}{l}0.037^{* *} \\
(0.016)\end{array}$ & $\begin{array}{r}0.024^{*} \\
(0.014)\end{array}$ & $\begin{array}{c}0.010 \\
(0.015)\end{array}$ & $\begin{array}{c}0.024 \\
(0.025)\end{array}$ & $\begin{array}{l}0.112^{* * *} \\
(0.033)\end{array}$ & $\begin{array}{l}0.116^{* * *} \\
(0.033)\end{array}$ \\
\hline Second quintile & $\begin{array}{l}0.034^{* *} \\
(0.014)\end{array}$ & $\begin{array}{c}0.009 \\
(0.013)\end{array}$ & $\begin{array}{c}0.017 \\
(0.014)\end{array}$ & $\begin{array}{l}0.049^{* *} \\
(0.021)\end{array}$ & $\begin{array}{l}0.051^{* * *} \\
(0.021)\end{array}$ & $\begin{array}{l}0.050^{* *} \\
(0.021)\end{array}$ \\
\hline Third quintile & $\begin{array}{l}0.029^{* *} \\
(0.013)\end{array}$ & $\begin{array}{l}-0.004 \\
(0.011)\end{array}$ & $\begin{array}{c}0.012 \\
(0.013)\end{array}$ & $\begin{array}{l}0.053^{* * *} \\
(0.018)\end{array}$ & $\begin{array}{l}0.038^{* *} \\
(0.016)\end{array}$ & $\begin{array}{l}0.039^{* *} \\
(0.016)\end{array}$ \\
\hline Fourth quintile & $\begin{array}{c}0.023^{*} \\
(0.012)\end{array}$ & $\begin{array}{r}0.022^{*} \\
(0.011)\end{array}$ & $\begin{array}{c}0.002 \\
(0.011)\end{array}$ & $\begin{array}{c}0.017 \\
(0.015)\end{array}$ & $\begin{array}{c}0.011 \\
(0.013)\end{array}$ & $\begin{array}{c}0.010 \\
(0.013)\end{array}$ \\
\hline Female & $\begin{array}{l}0.061^{* * *} \\
(0.009)\end{array}$ & $\begin{array}{l}0.087^{* * *} \\
(0.008)\end{array}$ & $\begin{array}{l}0.089^{* * *} \\
(0.008)\end{array}$ & $\begin{array}{l}0.069^{* * * *} \\
(0.011)\end{array}$ & $\begin{array}{l}0.043^{* * *} \\
(0.013)\end{array}$ & $\begin{array}{l}0.043^{* * * *} \\
(0.013)\end{array}$ \\
\hline Child long-term illness & $\begin{array}{c}0.015 \\
(0.012)\end{array}$ & $\begin{array}{c}-0.014 \\
(0.010)\end{array}$ & $\begin{array}{l}-0.005 \\
(0.011)\end{array}$ & $\begin{array}{c}0.004 \\
(0.018)\end{array}$ & $\begin{array}{c}0.005 \\
(0.020)\end{array}$ & $\begin{array}{c}0.007 \\
(0.021)\end{array}$ \\
\hline Health conditions & $\begin{array}{c}0.004 \\
(0.004)\end{array}$ & $\begin{array}{c}0.005 \\
(0.003)\end{array}$ & $\begin{array}{c}0.003 \\
(0.003)\end{array}$ & $\begin{array}{c}0.001 \\
(0.005)\end{array}$ & $\begin{array}{c}0.006 \\
(0.010)\end{array}$ & $\begin{array}{c}0.005 \\
(0.010)\end{array}$ \\
\hline Main parent long-term illness & $\begin{array}{l}-0.015 \\
(0.010)\end{array}$ & $\begin{array}{l}-0.003 \\
(0.009)\end{array}$ & $\begin{array}{r}0.017^{*} \\
(0.010)\end{array}$ & $\begin{array}{c}0.007 \\
(0.014)\end{array}$ & $\begin{array}{l}-0.006 \\
(0.014)\end{array}$ & $\begin{array}{l}-0.004 \\
(0.015)\end{array}$ \\
\hline No. of siblings & $\begin{array}{c}0.003 \\
(0.004)\end{array}$ & $\begin{array}{l}-0.005 \\
(0.004)\end{array}$ & $\begin{array}{c}-0.011^{* *} \\
(0.004)\end{array}$ & $\begin{array}{l}-0.020^{* * * *} \\
(0.006)\end{array}$ & $\begin{array}{l}-0.024^{* * *} \\
(0.006)\end{array}$ & $\begin{array}{l}-0.024^{* * *} \\
(0.006)\end{array}$ \\
\hline Birthweight & $\begin{array}{l}0.106^{* * *} \\
(0.008)\end{array}$ & $\begin{array}{l}0.084^{* * *} \\
(0.007)\end{array}$ & $\begin{array}{l}0.055^{* * *} \\
(0.007)\end{array}$ & $\begin{array}{l}0.033^{* * *} \\
(0.010)\end{array}$ & $\begin{array}{l}0.024^{* *} \\
(0.010)\end{array}$ & $\begin{array}{l}0.027^{* * * *} \\
(0.010)\end{array}$ \\
\hline Weight gain 9 months -3 (kg) & $\begin{array}{l}0.075^{* * *} \\
(0.005)\end{array}$ & $\begin{array}{l}0.064^{* * *} \\
(0.004)\end{array}$ & $\begin{array}{l}0.039^{* * *} \\
(0.004)\end{array}$ & $\begin{array}{l}0.035^{* * * *} \\
(0.005)\end{array}$ & $\begin{array}{l}0.022^{* * *} \\
(0.007)\end{array}$ & $\begin{array}{l}0.022^{* * *} \\
(0.007)\end{array}$ \\
\hline \multicolumn{7}{|l|}{$\underline{\text { Main Parent's education }}$} \\
\hline NVQ level 1 & $\begin{array}{c}0.008 \\
(0.021)\end{array}$ & $\begin{array}{c}0.018 \\
(0.019)\end{array}$ & $\begin{array}{l}-0.028 \\
(0.019)\end{array}$ & $\begin{array}{c}-0.016 \\
(0.027)\end{array}$ & $\begin{array}{l}-0.009 \\
(0.032)\end{array}$ & $\begin{array}{l}-0.014 \\
(0.033)\end{array}$ \\
\hline NVQ level 2 & $\begin{array}{c}-0.004 \\
(0.016)\end{array}$ & $\begin{array}{c}-0.007 \\
(0.014)\end{array}$ & $\begin{array}{c}-0.006 \\
(0.016)\end{array}$ & $\begin{array}{c}-0.005 \\
(0.022)\end{array}$ & $\begin{array}{c}-0.003 \\
(0.023)\end{array}$ & $\begin{array}{c}-0.006 \\
(0.024)\end{array}$ \\
\hline NVQ level 3 & $\begin{array}{c}-0.004 \\
(0.018)\end{array}$ & $\begin{array}{c}-0.001 \\
(0.016)\end{array}$ & $\begin{array}{r}-0.030^{*} \\
(0.017)\end{array}$ & $\begin{array}{c}-0.023 \\
(0.024)\end{array}$ & $\begin{array}{c}-0.023 \\
(0.025)\end{array}$ & $\begin{array}{c}-0.028 \\
(0.025)\end{array}$ \\
\hline NVQ level 4 & $\begin{array}{c}0.001 \\
(0.017)\end{array}$ & $\begin{array}{c}0.003 \\
(0.015)\end{array}$ & $\begin{array}{c}-0.019 \\
(0.017)\end{array}$ & $\begin{array}{c}-0.011 \\
(0.024)\end{array}$ & $\begin{array}{l}-0.004 \\
(0.024)\end{array}$ & $\begin{array}{l}-0.008 \\
(0.025)\end{array}$ \\
\hline NVQ level 5 & $\begin{array}{c}0.071^{* *} \\
(0.031)\end{array}$ & $\begin{array}{c}0.002 \\
(0.024)\end{array}$ & $\begin{array}{c}-0.024 \\
(0.024)\end{array}$ & $\begin{array}{c}-0.016 \\
(0.035)\end{array}$ & $\begin{array}{c}-0.049 \\
(0.031)\end{array}$ & $\begin{array}{c}-0.052 \\
(0.032)\end{array}$ \\
\hline \multicolumn{7}{|l|}{$\underline{\text { Ethnicity }}$} \\
\hline Mixed & $\begin{array}{c}0.031 \\
(0.052)\end{array}$ & $\begin{array}{l}-0.008 \\
(0.037)\end{array}$ & $\begin{array}{c}-0.051 \\
(0.030)\end{array}$ & $\begin{array}{c}0.049 \\
(0.039)\end{array}$ & $\begin{array}{c}-0.030 \\
(0.049)\end{array}$ & $\begin{array}{c}-0.034 \\
(0.046)\end{array}$ \\
\hline Indian & $\begin{array}{l}-0.083^{* * *} \\
(0.023)\end{array}$ & $\begin{array}{c}0.017 \\
(0.036)\end{array}$ & $\begin{array}{c}0.045 \\
(0.036)\end{array}$ & $\begin{array}{c}0.059 \\
(0.042)\end{array}$ & $\begin{array}{c}0.097 \\
(0.094)\end{array}$ & $\begin{array}{c}0.101 \\
(0.099)\end{array}$ \\
\hline Pakistani and Bangladeshi & $\begin{array}{l}-0.020 \\
(0.022)\end{array}$ & $\begin{array}{c}-0.011 \\
(0.021)\end{array}$ & $\begin{array}{c}-0.002 \\
(0.023)\end{array}$ & $\begin{array}{l}0.066^{* * *} \\
(0.034)\end{array}$ & $\begin{array}{l}-0.000 \\
(0.029)\end{array}$ & $\begin{array}{c}-0.003 \\
(0.029)\end{array}$ \\
\hline Black or Black British & $\begin{array}{c}0.014 \\
(0.032)\end{array}$ & $\begin{array}{c}0.062^{* *} \\
(0.032)\end{array}$ & $\begin{array}{c}0.069^{* *} \\
(0.035)\end{array}$ & $\begin{array}{l}0.114^{* * *} \\
(0.043)\end{array}$ & $\begin{array}{c}0.041 \\
(0.037)\end{array}$ & $\begin{array}{c}0.039 \\
(0.037)\end{array}$ \\
\hline Other Ethnic group (inc Chinese,Other) & $\begin{array}{c}-0.013 \\
(0.038)\end{array}$ & $\begin{array}{c}-0.037 \\
(0.028)\end{array}$ & $\begin{array}{c}-0.019 \\
(0.035)\end{array}$ & $\begin{array}{c}0.002 \\
(0.063)\end{array}$ & $\begin{array}{c}0.063 \\
(0.073)\end{array}$ & $\begin{array}{c}0.056 \\
(0.072)\end{array}$ \\
\hline $\begin{array}{l}\mathbb{E}[\operatorname{Pr}(\text { overweight }) \mid x] \\
\mathrm{N}\end{array}$ & $\begin{array}{r}0.161 \\
10.143\end{array}$ & $\begin{array}{r}0.133 \\
10.485\end{array}$ & $\begin{array}{l}0.124 \\
9.405\end{array}$ & $\begin{array}{l}0.198 \\
7,887\end{array}$ & $\begin{array}{l}0.155 \\
6.674\end{array}$ & $\begin{array}{l}0.156 \\
6.674\end{array}$ \\
\hline
\end{tabular}

Note: $*, * *$ and $* * *$ denote statistical significance it $10 \%, 5 \%$ and $1 \%$ respectively. The outcome in each column is whether or not a child is overweight, defined using the the IOTF cutoffs (Table A1). The effects reported are marginal effects obtained after estimating Equation 4 fixing the independent variables at their sample mean. The MCS data do not contain parents' BMI at age 14, so columns 5 and 6 use BMI from age 11 or as predicted to define obesity. All observations are adjusted for the probability of attrition and being sampled, see (Hansen et al., 2014). The omitted categories are income: highest quintile; parents' education: no qualifications; ethnicity: white. Female is an indicator of whether a child is female. Appendix Table A. 2 describes how the index was constructed. $\mathbb{E}[\operatorname{Pr}($ overweight $) \mid x]$ represents estimated the conditional expectation of a child being overweight. The main parent is the mother for over $99 \%$ of children at 9 months. Ns differ across columns because of missing data. 
Table B15: Index of healthy behaviours and obesity in children across ages with full controls

\begin{tabular}{|c|c|c|c|c|c|c|}
\hline & & & & & \multicolumn{2}{|c|}{ (5)-(6) Age 14} \\
\hline & $\begin{array}{c}\text { (1) } \\
\text { Age } 3\end{array}$ & $\begin{array}{c}(2) \\
\text { Age } 5\end{array}$ & $\begin{array}{c}\text { (3) } \\
\text { Age } 7\end{array}$ & $\begin{array}{c}\text { (4) } \\
\text { Age } 11\end{array}$ & $\begin{array}{l}\text { Parental weight } \\
\text { constant }\end{array}$ & $\begin{array}{c}\text { Parental weight } \\
\text { predicted }\end{array}$ \\
\hline Healthy lifestyle & $\begin{array}{c}0.009^{* *} \\
(0.004)\end{array}$ & $\begin{array}{l}-0.001 \\
(0.004)\end{array}$ & $\begin{array}{l}-0.001 \\
(0.004)\end{array}$ & $\begin{array}{l}-0.022^{* * *} \\
(0.005)\end{array}$ & $\begin{array}{l}-0.007 \\
(0.006)\end{array}$ & $\begin{array}{l}-0.007 \\
(0.006)\end{array}$ \\
\hline Main parent overweight & $\begin{array}{l}0.018^{* * *} \\
(0.005)\end{array}$ & $\begin{array}{l}0.023^{* * *} \\
(0.005)\end{array}$ & $\begin{array}{l}0.031^{* * *} \\
(0.005)\end{array}$ & $\begin{array}{l}0.031^{* * *} \\
(0.006)\end{array}$ & $\begin{array}{l}0.022^{* * *} \\
(0.006)\end{array}$ & $\begin{array}{l}0.021^{* * *} \\
(0.005)\end{array}$ \\
\hline Main parent obese/morbidly obese & $\begin{array}{l}0.041^{* * *} \\
(0.008)\end{array}$ & $\begin{array}{l}0.057^{* * *} \\
(0.008)\end{array}$ & $\begin{array}{l}0.079^{* * *} \\
(0.009)\end{array}$ & $\begin{array}{l}0.071^{* * *} \\
(0.009)\end{array}$ & $\begin{array}{l}0.092^{* * *} \\
(0.011)\end{array}$ & $\begin{array}{l}0.086^{* * *} \\
(0.010)\end{array}$ \\
\hline \multicolumn{7}{|l|}{ Income quintiles } \\
\hline Lowest quintile & $\begin{array}{l}0.017^{* *} \\
(0.008)\end{array}$ & $\begin{array}{r}0.014^{*} \\
(0.008)\end{array}$ & $\begin{array}{r}0.013^{*} \\
(0.008)\end{array}$ & $\begin{array}{l}0.026^{* *} \\
(0.011)\end{array}$ & $\begin{array}{l}0.063^{* * *} \\
(0.018)\end{array}$ & $\begin{array}{l}0.063^{* * *} \\
(0.017)\end{array}$ \\
\hline Second quintile & $\begin{array}{c}0.011 \\
(0.006)\end{array}$ & $\begin{array}{c}0.010 \\
(0.007)\end{array}$ & $\begin{array}{c}0.010 \\
(0.007)\end{array}$ & $\begin{array}{l}0.028^{* * *} \\
(0.009)\end{array}$ & $\begin{array}{l}0.024^{* * *} \\
(0.009)\end{array}$ & $\begin{array}{l}0.024^{* * * *} \\
(0.009)\end{array}$ \\
\hline Third quintile & $\begin{array}{c}0.003 \\
(0.006)\end{array}$ & $\begin{array}{c}0.005 \\
(0.006)\end{array}$ & $\begin{array}{c}0.006 \\
(0.006)\end{array}$ & $\begin{array}{r}0.015^{*} \\
(0.008)\end{array}$ & $\begin{array}{l}0.014^{* *} \\
(0.007)\end{array}$ & $\begin{array}{l}0.015^{* *} \\
(0.007)\end{array}$ \\
\hline Fourth quintile & $\begin{array}{r}0.012^{*} \\
(0.006)\end{array}$ & $\begin{array}{c}0.005 \\
(0.006)\end{array}$ & $\begin{array}{c}0.005 \\
(0.006)\end{array}$ & $\begin{array}{c}0.006 \\
(0.006)\end{array}$ & $\begin{array}{c}0.008 \\
(0.006)\end{array}$ & $\begin{array}{c}0.007 \\
(0.006)\end{array}$ \\
\hline Female & $\begin{array}{l}0.019^{* * *} \\
(0.004)\end{array}$ & $\begin{array}{l}0.014^{* * *} \\
(0.004)\end{array}$ & $\begin{array}{l}0.022^{* * *} \\
(0.004)\end{array}$ & $\begin{array}{l}0.017^{* * *} \\
(0.005)\end{array}$ & $\begin{array}{l}0.018^{* * *} \\
(0.005)\end{array}$ & $\begin{array}{l}0.018^{* * *} \\
(0.005)\end{array}$ \\
\hline Child long-term illness & $\begin{array}{l}-0.010^{*} \\
(0.005)\end{array}$ & $\begin{array}{l}0.014^{* *} \\
(0.006)\end{array}$ & $\begin{array}{c}0.002 \\
(0.006)\end{array}$ & $\begin{array}{c}0.002 \\
(0.007)\end{array}$ & $\begin{array}{l}0.007 \\
(0.009)\end{array}$ & $\begin{array}{c}0.007 \\
(0.009)\end{array}$ \\
\hline Health conditions & $\begin{array}{c}0.002 \\
(0.002)\end{array}$ & $\begin{array}{c}0.001 \\
(0.002)\end{array}$ & $\begin{array}{c}0.004^{* *} \\
(0.002)\end{array}$ & $\begin{array}{l}0.004^{* *} \\
(0.002)\end{array}$ & $\begin{array}{c}0.003 \\
(0.003)\end{array}$ & $\begin{array}{c}0.003 \\
(0.003)\end{array}$ \\
\hline Main parent long-term illness & $\begin{array}{l}-0.001 \\
(0.005)\end{array}$ & $\begin{array}{r}0.008^{*} \\
(0.005)\end{array}$ & $\begin{array}{c}0.005 \\
(0.005)\end{array}$ & $\begin{array}{l}0.012^{* *} \\
(0.006)\end{array}$ & $\begin{array}{c}0.006 \\
(0.006)\end{array}$ & $\begin{array}{c}0.007 \\
(0.006)\end{array}$ \\
\hline No. of siblings & $\begin{array}{c}0.000 \\
(0.002)\end{array}$ & $\begin{array}{l}-0.006^{* * *} \\
(0.002)\end{array}$ & $\begin{array}{l}-0.005^{* *} \\
(0.002)\end{array}$ & $\begin{array}{l}-0.008^{* * *} \\
(0.003)\end{array}$ & $\begin{array}{l}-0.007^{* * *} \\
(0.003)\end{array}$ & $\begin{array}{l}-0.007^{* * *} \\
(0.003)\end{array}$ \\
\hline Birthweight & $\begin{array}{l}0.011^{* * * *} \\
(0.004)\end{array}$ & $\begin{array}{l}0.021^{* * *} \\
(0.004)\end{array}$ & $\begin{array}{l}0.010^{* * * *} \\
(0.004)\end{array}$ & $\begin{array}{l}0.015^{* * *} \\
(0.004)\end{array}$ & $\begin{array}{l}0.019^{* * *} \\
(0.004)\end{array}$ & $\begin{array}{l}0.020^{* * * *} \\
(0.004)\end{array}$ \\
\hline Weight gain 9 months $-3(\mathrm{~kg})$ & $\begin{array}{l}0.019^{* * *} \\
(0.002)\end{array}$ & $\begin{array}{l}0.014^{* * *} \\
(0.002)\end{array}$ & $\begin{array}{l}0.014^{* * *} \\
(0.002)\end{array}$ & $\begin{array}{l}0.011^{* * *} \\
(0.002)\end{array}$ & $\begin{array}{l}0.009^{* * *} \\
(0.002)\end{array}$ & $\begin{array}{l}0.008^{* * *} \\
(0.002)\end{array}$ \\
\hline \multicolumn{7}{|l|}{ Main Parent's education } \\
\hline NVQ level 1 & $\begin{array}{c}0.006 \\
(0.010)\end{array}$ & $\begin{array}{l}-0.002 \\
(0.010)\end{array}$ & $\begin{array}{c}0.001 \\
(0.010)\end{array}$ & $\begin{array}{c}0.005 \\
(0.012)\end{array}$ & $\begin{array}{c}0.010 \\
(0.012)\end{array}$ & $\begin{array}{c}0.009 \\
(0.012)\end{array}$ \\
\hline NVQ level 2 & $\begin{array}{l}-0.008 \\
(0.007)\end{array}$ & $\begin{array}{l}-0.006 \\
(0.007)\end{array}$ & $\begin{array}{c}0.003 \\
(0.008)\end{array}$ & $\begin{array}{c}-0.012 \\
(0.009)\end{array}$ & $\begin{array}{c}0.008 \\
(0.009)\end{array}$ & $\begin{array}{c}0.007 \\
(0.009)\end{array}$ \\
\hline NVQ level 3 & $\begin{array}{l}-0.012 \\
(0.008)\end{array}$ & $\begin{array}{c}-0.019^{* *} \\
(0.008)\end{array}$ & $\begin{array}{c}0.001 \\
(0.009)\end{array}$ & $\begin{array}{l}-0.025^{* * *} \\
(0.009)\end{array}$ & $\begin{array}{c}0.005 \\
(0.010)\end{array}$ & $\begin{array}{c}0.004 \\
(0.010)\end{array}$ \\
\hline NVQ level 4 & $\begin{array}{l}-0.007 \\
(0.008)\end{array}$ & $\begin{array}{l}-0.020^{* * *} \\
(0.008)\end{array}$ & $\begin{array}{c}-0.010 \\
(0.008)\end{array}$ & $\begin{array}{c}-0.015 \\
(0.010)\end{array}$ & $\begin{array}{c}-0.005 \\
(0.009)\end{array}$ & $\begin{array}{c}-0.005 \\
(0.009)\end{array}$ \\
\hline NVQ level 5 & $\begin{array}{c}0.006 \\
(0.015)\end{array}$ & $\begin{array}{c}-0.028^{* *} \\
(0.011)\end{array}$ & $\begin{array}{c}-0.026^{* *} \\
(0.010)\end{array}$ & $\begin{array}{c}-0.035^{* *} \\
(0.013)\end{array}$ & $\begin{array}{c}-0.010 \\
(0.013)\end{array}$ & $\begin{array}{c}-0.010 \\
(0.013)\end{array}$ \\
\hline \multicolumn{7}{|l|}{ Ethnicity } \\
\hline Mixed & $\begin{array}{c}0.041^{* *} \\
(0.026)\end{array}$ & $\begin{array}{c}0.007 \\
(0.019)\end{array}$ & $\begin{array}{c}-0.023 \\
(0.013)\end{array}$ & $\begin{array}{c}0.028^{*} \\
(0.018)\end{array}$ & $\begin{array}{c}-0.006 \\
(0.023)\end{array}$ & $\begin{array}{c}-0.006 \\
(0.022)\end{array}$ \\
\hline Indian & $\begin{array}{c}-0.002 \\
(0.016)\end{array}$ & $\begin{array}{c}0.014 \\
(0.021)\end{array}$ & $\begin{array}{c}0.030 \\
(0.024)\end{array}$ & $\begin{array}{r}-0.022^{*} \\
(0.008)\end{array}$ & $\begin{array}{l}-0.007 \\
(0.015)\end{array}$ & $\begin{array}{l}-0.008 \\
(0.015)\end{array}$ \\
\hline Pakistani and Bangladeshi & $\begin{array}{c}0.004 \\
(0.009)\end{array}$ & $\begin{array}{l}0.032^{* * *} \\
(0.014)\end{array}$ & $\begin{array}{r}0.022^{*} \\
(0.013)\end{array}$ & $\begin{array}{c}0.021 \\
(0.015)\end{array}$ & $\begin{array}{c}0.006 \\
(0.013)\end{array}$ & $\begin{array}{c}0.006 \\
(0.013)\end{array}$ \\
\hline Black or Black British & $\begin{array}{l}0.044^{* * *} \\
(0.018)\end{array}$ & $\begin{array}{c}0.049^{* * *} \\
(0.019)\end{array}$ & $\begin{array}{l}0.069^{* * *} \\
(0.020)\end{array}$ & $\begin{array}{l}0.034^{* *} \\
(0.019)\end{array}$ & $\begin{array}{c}0.012 \\
(0.016)\end{array}$ & $\begin{array}{c}0.012 \\
(0.016)\end{array}$ \\
\hline Other Ethnic group (inc Chinese,Other) & $\begin{array}{c}0.017 \\
(0.022)\end{array}$ & $\begin{array}{c}0.015 \\
(0.023)\end{array}$ & $\begin{array}{c}0.021 \\
(0.027)\end{array}$ & $\begin{array}{l}-0.000 \\
(0.022)\end{array}$ & $\begin{array}{l}-0.007 \\
(0.017)\end{array}$ & $\begin{array}{l}-0.008 \\
(0.016)\end{array}$ \\
\hline $\mathbb{E}[\operatorname{Pr}($ overweight $) \mid x]$ & 0.038 & 0.039 & 0.042 & 0.042 & 0.039 & 0.038 \\
\hline $\mathrm{N}$ & 10,714 & 11,119 & 10,186 & 8,426 & 7,067 & 7,067 \\
\hline
\end{tabular}

Note: $*, * *$ and $* * *$ denote statistical significance it $10 \%, 5 \%$ and $1 \%$ respectively. The outcome in each column is whether or not a child is obese, defined using the the IOTF cutoffs (Table A1). The effects reported are marginal effects obtained after estimating Equation 4 fixing the independent variables at their sample mean. The MCS data do not contain parents' BMI at age 14, so columns 5 and 6 use BMI from age 11 or as predicted to define obesity. All observations are adjusted for the probability of attrition and being sampled, see (Hansen et al., 2014). The omitted categories are income: highest quintile; parents' education: no qualifications; ethnicity: white. Female is an indicator of whether a child is female. Appendix Table A.2 describes how the index was constructed. $\mathbb{E}[\operatorname{Pr}($ obese $) \mid \boldsymbol{x}]$ represents estimated the conditional expectation of a child being obese. The main parent is the mother for over $99 \%$ of children at 9 months. Ns differ across columns because of missing data. 
Table B16: Index of healthy behaviours and overweight and obesity in children across ages with full controls

\begin{tabular}{|c|c|c|c|c|c|c|}
\hline & & & & & \multicolumn{2}{|c|}{ (5)-(6) Age 14} \\
\hline & $\begin{array}{c}\text { (1) } \\
\text { Age } 3\end{array}$ & $\begin{array}{c}\text { (2) } \\
\text { Age } 5\end{array}$ & $\begin{array}{c}\text { (3) } \\
\text { Age } 7\end{array}$ & $\begin{array}{c}(4) \\
\text { Age } 11\end{array}$ & $\begin{array}{l}\text { Parental weight } \\
\text { constant }\end{array}$ & $\begin{array}{l}\text { Parental weight } \\
\text { predicted }\end{array}$ \\
\hline Healthy lifestyle & $\begin{array}{c}0.005 \\
(0.009)\end{array}$ & $\begin{array}{c}0.005 \\
(0.009)\end{array}$ & $\begin{array}{c}-0.009 \\
(0.009)\end{array}$ & $\begin{array}{l}-0.049^{* * *} \\
(0.012)\end{array}$ & $\begin{array}{r}-0.025^{*} \\
(0.013)\end{array}$ & $\begin{array}{r}-0.026^{*} \\
(0.013)\end{array}$ \\
\hline Main parent overweight & $\begin{array}{l}0.036^{* * *} \\
(0.011)\end{array}$ & $\begin{array}{l}0.077^{* * *} \\
(0.010)\end{array}$ & $\begin{array}{l}0.085^{* * *} \\
(0.010)\end{array}$ & $\begin{array}{l}0.122^{* * *} \\
(0.013)\end{array}$ & $\begin{array}{l}0.119^{* * *} \\
(0.014)\end{array}$ & $\begin{array}{l}0.090^{* * *} \\
(0.013)\end{array}$ \\
\hline Main parent obese/morbidly obese & $\begin{array}{l}0.094^{* * *} \\
(0.015)\end{array}$ & $\begin{array}{l}0.169^{* * *} \\
(0.015)\end{array}$ & $\begin{array}{l}0.159^{* * *} \\
(0.014)\end{array}$ & $\begin{array}{l}0.249^{* * *} \\
(0.017)\end{array}$ & $\begin{array}{l}0.241^{* * *} \\
(0.018)\end{array}$ & $\begin{array}{l}0.238^{* * *} \\
(0.018)\end{array}$ \\
\hline \multicolumn{7}{|l|}{ Income quintiles } \\
\hline Lowest quintile & $\begin{array}{l}0.054^{* * *} \\
(0.017)\end{array}$ & $\begin{array}{l}0.037^{* *} \\
(0.016)\end{array}$ & $\begin{array}{l}0.025 \\
(0.016)\end{array}$ & $\begin{array}{l}0.051^{* *} \\
(0.026)\end{array}$ & $\begin{array}{l}0.165^{* * *} \\
(0.033)\end{array}$ & $\begin{array}{l}0.169^{* * * *} \\
(0.034)\end{array}$ \\
\hline Second quintile & $\begin{array}{l}0.042^{* * *} \\
(0.015)\end{array}$ & $\begin{array}{c}0.017 \\
(0.014)\end{array}$ & $\begin{array}{c}0.023 \\
(0.015)\end{array}$ & $\begin{array}{l}0.074^{* * *} \\
(0.022)\end{array}$ & $\begin{array}{l}0.073^{* * *} \\
(0.022)\end{array}$ & $\begin{array}{l}0.073^{* * * *} \\
(0.022)\end{array}$ \\
\hline Third quintile & $\begin{array}{c}0.030^{* *} \\
(0.014)\end{array}$ & $\begin{array}{c}0.001 \\
(0.013)\end{array}$ & $\begin{array}{l}0.018 \\
(0.014)\end{array}$ & $\begin{array}{l}0.066^{* * *} \\
(0.019)\end{array}$ & $\begin{array}{l}0.052^{* * *} \\
(0.017)\end{array}$ & $\begin{array}{l}0.053^{* * *} \\
(0.017)\end{array}$ \\
\hline Fourth quintile & $\begin{array}{l}0.031^{* *} \\
(0.013)\end{array}$ & $\begin{array}{l}0.026^{* *} \\
(0.013)\end{array}$ & $\begin{array}{c}0.006 \\
(0.013)\end{array}$ & $\begin{array}{c}0.023 \\
(0.016)\end{array}$ & $\begin{array}{c}0.018 \\
(0.014)\end{array}$ & $\begin{array}{c}0.017 \\
(0.014)\end{array}$ \\
\hline Female & $\begin{array}{l}0.077^{* * *} \\
(0.010)\end{array}$ & $\begin{array}{l}0.098^{* * *} \\
(0.009)\end{array}$ & $\begin{array}{l}0.112^{* * *} \\
(0.009)\end{array}$ & $\begin{array}{l}0.083^{* * *} \\
(0.012)\end{array}$ & $\begin{array}{l}0.060^{* * *} \\
(0.013)\end{array}$ & $\begin{array}{l}0.061^{* * *} \\
(0.013)\end{array}$ \\
\hline Child long-term illness & $\begin{array}{c}0.007 \\
(0.013)\end{array}$ & $\begin{array}{l}-0.000 \\
(0.012)\end{array}$ & $\begin{array}{c}-0.002 \\
(0.012)\end{array}$ & $\begin{array}{c}0.006 \\
(0.018)\end{array}$ & $\begin{array}{c}0.011 \\
(0.022)\end{array}$ & $\begin{array}{c}0.012 \\
(0.023)\end{array}$ \\
\hline Health conditions & $\begin{array}{c}0.006 \\
(0.004)\end{array}$ & $\begin{array}{c}0.006 \\
(0.004)\end{array}$ & $\begin{array}{c}0.005 \\
(0.004)\end{array}$ & $\begin{array}{c}0.005 \\
(0.005)\end{array}$ & $\begin{array}{c}0.010 \\
(0.011)\end{array}$ & $\begin{array}{c}0.010 \\
(0.011)\end{array}$ \\
\hline Main parent long-term illness & $\begin{array}{l}-0.016 \\
(0.011)\end{array}$ & $\begin{array}{c}0.005 \\
(0.010)\end{array}$ & $\begin{array}{l}0.022^{* *} \\
(0.011)\end{array}$ & $\begin{array}{c}0.017 \\
(0.014)\end{array}$ & $\begin{array}{c}0.002 \\
(0.015)\end{array}$ & $\begin{array}{c}0.005 \\
(0.016)\end{array}$ \\
\hline No. of siblings & $\begin{array}{c}0.003 \\
(0.005)\end{array}$ & $\begin{array}{l}-0.010^{* *} \\
(0.005)\end{array}$ & $\begin{array}{l}-0.014^{* * *} \\
(0.005)\end{array}$ & $\begin{array}{c}-0.028^{* * *} \\
(0.007)\end{array}$ & $\begin{array}{l}-0.030^{* * *} \\
(0.007)\end{array}$ & $\begin{array}{l}-0.030^{* * *} \\
(0.007)\end{array}$ \\
\hline Birthweight & $\begin{array}{l}0.115^{* * *} \\
(0.009)\end{array}$ & $\begin{array}{l}0.104^{* * *} \\
(0.008)\end{array}$ & $\begin{array}{l}0.062^{* * *} \\
(0.008)\end{array}$ & $\begin{array}{l}0.047^{* * *} \\
(0.010)\end{array}$ & $\begin{array}{l}0.043^{* * *} \\
(0.011)\end{array}$ & $\begin{array}{l}0.048^{* * * *} \\
(0.011)\end{array}$ \\
\hline Weight gain 9 months $-3(\mathrm{~kg})$ & $\begin{array}{l}0.092^{* * *} \\
(0.005)\end{array}$ & $\begin{array}{l}0.077^{* * *} \\
(0.005)\end{array}$ & $\begin{array}{l}0.052^{* * *} \\
(0.004)\end{array}$ & $\begin{array}{l}0.045^{* * *} \\
(0.005)\end{array}$ & $\begin{array}{l}0.031^{* * *} \\
(0.007)\end{array}$ & $\begin{array}{l}0.031^{* * *} \\
(0.007)\end{array}$ \\
\hline \multicolumn{7}{|l|}{ Main Parent's education } \\
\hline NVQ level 1 & $\begin{array}{c}0.011 \\
(0.022)\end{array}$ & $\begin{array}{c}0.013 \\
(0.021)\end{array}$ & $\begin{array}{c}-0.028 \\
(0.020)\end{array}$ & $\begin{array}{c}-0.012 \\
(0.028)\end{array}$ & $\begin{array}{c}0.001 \\
(0.033)\end{array}$ & $\begin{array}{c}-0.005 \\
(0.034)\end{array}$ \\
\hline NVQ level 2 & $\begin{array}{c}-0.015 \\
(0.017)\end{array}$ & $\begin{array}{c}-0.012 \\
(0.016)\end{array}$ & $\begin{array}{c}-0.003 \\
(0.017)\end{array}$ & $\begin{array}{l}-0.018 \\
(0.023)\end{array}$ & $\begin{array}{c}0.004 \\
(0.024)\end{array}$ & $\begin{array}{c}0.000 \\
(0.025)\end{array}$ \\
\hline NVQ level 3 & $\begin{array}{l}-0.017 \\
(0.019)\end{array}$ & $\begin{array}{c}-0.019 \\
(0.018)\end{array}$ & $\begin{array}{c}-0.026 \\
(0.019)\end{array}$ & $\begin{array}{l}-0.047^{*} \\
(0.025)\end{array}$ & $\begin{array}{l}-0.020 \\
(0.026)\end{array}$ & $\begin{array}{c}-0.025 \\
(0.026)\end{array}$ \\
\hline NVQ level 4 & $\begin{array}{c}-0.008 \\
(0.018)\end{array}$ & $\begin{array}{l}-0.017 \\
(0.017)\end{array}$ & $\begin{array}{c}-0.027 \\
(0.018)\end{array}$ & $\begin{array}{l}-0.027 \\
(0.025)\end{array}$ & $\begin{array}{l}-0.010 \\
(0.025)\end{array}$ & $\begin{array}{c}-0.014 \\
(0.025)\end{array}$ \\
\hline NVQ level 5 & $\begin{array}{c}0.070^{* *} \\
(0.033)\end{array}$ & $\begin{array}{c}-0.023 \\
(0.026)\end{array}$ & $\begin{array}{c}-0.047^{*} \\
(0.026)\end{array}$ & $\begin{array}{l}-0.045 \\
(0.037)\end{array}$ & $\begin{array}{l}-0.059^{*} \\
(0.033)\end{array}$ & $\begin{array}{r}-0.062^{*} \\
(0.034)\end{array}$ \\
\hline \multicolumn{7}{|l|}{ Ethnicity } \\
\hline Mixed & $\begin{array}{c}0.061 \\
(0.052)\end{array}$ & $\begin{array}{c}-0.004 \\
(0.040)\end{array}$ & $\begin{array}{c}-0.073^{*} \\
(0.033)\end{array}$ & $\begin{array}{c}0.072^{*} \\
(0.040)\end{array}$ & $\begin{array}{c}-0.034 \\
(0.057)\end{array}$ & $\begin{array}{c}-0.039 \\
(0.054)\end{array}$ \\
\hline Indian & $\begin{array}{c}-0.082^{* *} \\
(0.028)\end{array}$ & $\begin{array}{c}0.032 \\
(0.040)\end{array}$ & $\begin{array}{l}0.073^{* *} \\
(0.039)\end{array}$ & $\begin{array}{c}0.039 \\
(0.043)\end{array}$ & $\begin{array}{c}0.097 \\
(0.093)\end{array}$ & $\begin{array}{c}0.100 \\
(0.098)\end{array}$ \\
\hline Pakistani and Bangladeshi & $\begin{array}{c}-0.016 \\
(0.023)\end{array}$ & $\begin{array}{c}0.024 \\
(0.025)\end{array}$ & $\begin{array}{c}0.022 \\
(0.026)\end{array}$ & $\begin{array}{l}0.084^{* * *} \\
(0.034)\end{array}$ & $\begin{array}{c}0.006 \\
(0.031)\end{array}$ & $\begin{array}{c}0.002 \\
(0.031)\end{array}$ \\
\hline Black or Black British & $\begin{array}{r}0.060^{*} \\
(0.035)\end{array}$ & $\begin{array}{l}0.109^{* * *} \\
(0.035)\end{array}$ & $\begin{array}{l}0.126^{* * *} \\
(0.036)\end{array}$ & $\begin{array}{l}0.140^{* * *} \\
(0.044)\end{array}$ & $\begin{array}{c}0.053 \\
(0.040)\end{array}$ & $\begin{array}{c}0.051 \\
(0.040)\end{array}$ \\
\hline Other Ethnic group (inc Chinese, Other) & $\begin{array}{c}0.001 \\
(0.042)\end{array}$ & $\begin{array}{l}-0.019 \\
(0.038)\end{array}$ & $\begin{array}{c}0.003 \\
(0.045)\end{array}$ & $\begin{array}{c}0.001 \\
(0.067)\end{array}$ & $\begin{array}{c}0.056 \\
(0.074)\end{array}$ & $\begin{array}{c}0.050 \\
(0.075)\end{array}$ \\
\hline $\mathbb{E}[\operatorname{Pr}($ overweight $) \mid x]$ & 0.199 & 0.175 & 0.165 & 0.241 & 0.196 & 0.197 \\
\hline $\mathrm{N}$ & 10,714 & 11,119 & 10,186 & 8,426 & 7,067 & 7,067 \\
\hline
\end{tabular}

Note: $* * *$ and $* * *$ denote statistical significance it $10 \%, 5 \%$ and $1 \%$ respectively. The outcome in each column is whether or not a child is overweight or obese, defined using the the IOTF cutoffs (Table A1). The effects reported are marginal effects obtained after estimating Equation 4 fixing the independent variables at their sample mean. The MCS data do not contain parents' BMI at age 14, so columns 5 and 6 use BMI from age 11 or as predicted to define obesity. All observations are adjusted for the probability of attrition and being sampled, see (Hansen et al., 2014). The omitted categories are income: highest quintile; parents' education: no qualifications; ethnicity: white. Female is an indicator of whether a child is female. Appendix Table A.2 describes how the index was constructed. $\mathbb{E}[\operatorname{Pr}($ overweight $\cup$ obese $) \mid x]$ represents estimated the conditional expectation of a child being overweight or obese. The main parent is the mother for over $99 \%$ of children at 9 months. Ns differ across columns because of missing data. 
Table B17(a): Individual healthy behaviours and overweight in children across ages

\begin{tabular}{|c|c|c|c|c|c|c|}
\hline & & & & & \multicolumn{2}{|c|}{ (5)-(6) Age 14} \\
\hline & $\begin{array}{c}(1) \\
\text { Age } 3\end{array}$ & $\begin{array}{c}(2) \\
\text { Age } 5\end{array}$ & $\begin{array}{c}(3) \\
\text { Age } 7\end{array}$ & $\begin{array}{c}(4) \\
\text { Age } 11\end{array}$ & $\begin{array}{l}\text { Parental weight } \\
\text { constant }\end{array}$ & $\begin{array}{c}\text { Parental weight } \\
\text { predicted }\end{array}$ \\
\hline Main parent overweight & $\begin{array}{l}0.022^{* *} \\
(0.010)\end{array}$ & $\begin{array}{l}0.061^{* * *} \\
(0.010)\end{array}$ & $\begin{array}{l}0.068^{* * *} \\
(0.011)\end{array}$ & $\begin{array}{l}0.100^{* * *} \\
(0.013)\end{array}$ & $\begin{array}{l}0.094^{* * *} \\
(0.013)\end{array}$ & $\begin{array}{l}0.067^{* * *} \\
(0.012)\end{array}$ \\
\hline Main parent obese/morbidly obese & $\begin{array}{l}0.061^{* * *} \\
(0.014)\end{array}$ & $\begin{array}{l}0.125^{* * *} \\
(0.014)\end{array}$ & $\begin{array}{l}0.093^{* * *} \\
(0.014)\end{array}$ & $\begin{array}{l}0.195^{* * *} \\
(0.016)\end{array}$ & $\begin{array}{l}0.167^{* * *} \\
(0.018)\end{array}$ & $\begin{array}{l}0.167^{* * *} \\
(0.017)\end{array}$ \\
\hline \multicolumn{7}{|l|}{ Income quintiles } \\
\hline Lowest quintile & $\begin{array}{l}0.038^{* *} \\
(0.016)\end{array}$ & $\begin{array}{c}0.026^{*} \\
(0.015)\end{array}$ & $\begin{array}{c}0.003 \\
(0.017)\end{array}$ & $\begin{array}{c}0.020 \\
(0.025)\end{array}$ & $\begin{array}{l}0.093^{* * *} \\
(0.029)\end{array}$ & $\begin{array}{l}0.095^{* * *} \\
(0.029)\end{array}$ \\
\hline Second quintile & $\begin{array}{l}0.036^{* *} \\
(0.015)\end{array}$ & $\begin{array}{c}0.009 \\
(0.014)\end{array}$ & $\begin{array}{c}0.013 \\
(0.016)\end{array}$ & $\begin{array}{l}0.044^{* *} \\
(0.021)\end{array}$ & $\begin{array}{l}0.052^{* *} \\
(0.021)\end{array}$ & $\begin{array}{l}0.051^{* *} \\
(0.021)\end{array}$ \\
\hline Third quintile & $\begin{array}{l}0.030^{* *} \\
(0.013)\end{array}$ & $\begin{array}{c}-0.004 \\
(0.012)\end{array}$ & $\begin{array}{c}0.005 \\
(0.014)\end{array}$ & $\begin{array}{l}0.051^{* * *} \\
(0.018)\end{array}$ & $\begin{array}{l}0.039^{* *} \\
(0.017)\end{array}$ & $\begin{array}{l}0.041^{* *} \\
(0.017)\end{array}$ \\
\hline Fourth quintile & $\begin{array}{c}0.025^{*} \\
(0.013)\end{array}$ & $\begin{array}{c}0.024^{*} \\
(0.012)\end{array}$ & $\begin{array}{c}-0.000 \\
(0.013)\end{array}$ & $\begin{array}{c}0.018 \\
(0.015)\end{array}$ & $\begin{array}{c}0.008 \\
(0.014)\end{array}$ & $\begin{array}{c}0.008 \\
(0.014)\end{array}$ \\
\hline \multicolumn{7}{|l|}{ Healthy behaviours } \\
\hline Fruit/veg once a day & $\begin{array}{c}0.014 \\
(0.025)\end{array}$ & $\begin{array}{c}0.010 \\
(0.008)\end{array}$ & $\begin{array}{c}0.003 \\
(0.009)\end{array}$ & $\begin{array}{c}0.007 \\
(0.011)\end{array}$ & $\begin{array}{c}0.012 \\
(0.013)\end{array}$ & $\begin{array}{c}0.012 \\
(0.013)\end{array}$ \\
\hline Regular meals & $\begin{array}{c}-0.004 \\
(0.009)\end{array}$ & $\begin{array}{c}0.003 \\
(0.008)\end{array}$ & & & & \\
\hline Physically active games once a week & $\begin{array}{c}-0.002 \\
(0.011)\end{array}$ & $\begin{array}{c}-0.004 \\
(0.009)\end{array}$ & $\begin{array}{c}-0.001 \\
(0.009)\end{array}$ & $\begin{array}{c}-0.030^{* * *} \\
(0.011)\end{array}$ & & \\
\hline Sport once a week & & $\begin{array}{c}-0.001 \\
(0.009)\end{array}$ & $\begin{array}{c}-0.026^{*} \\
(0.016)\end{array}$ & $\begin{array}{c}-0.029 \\
(0.020)\end{array}$ & & \\
\hline Sport with child once a week & & $\begin{array}{c}0.006 \\
(0.009)\end{array}$ & $\begin{array}{c}0.001 \\
(0.009)\end{array}$ & $\begin{array}{c}-0.010 \\
(0.020)\end{array}$ & & \\
\hline Breakfast every day & & & & $\begin{array}{c}-0.035^{* *} \\
(0.017)\end{array}$ & $\begin{array}{c}-0.037^{* * *} \\
(0.012)\end{array}$ & $\begin{array}{c}-0.038^{* * *} \\
(0.012)\end{array}$ \\
\hline Art. sweetened drinks less than once a week & & & & $\begin{array}{c}-0.010 \\
(0.011)\end{array}$ & $\begin{array}{c}-0.074^{\text {*** }} \\
(0.017)\end{array}$ & $\begin{array}{c}-0.077^{* * *} \\
(0.017)\end{array}$ \\
\hline Sweetened drinks less than once a week & & & & $\begin{array}{c}-0.005 \\
(0.012)\end{array}$ & $\begin{array}{c}0.027^{*} \\
(0.014)\end{array}$ & $\begin{array}{c}0.026^{*} \\
(0.014)\end{array}$ \\
\hline Fast food less than once a week & & & & & $\begin{array}{c}0.021 \\
(0.013)\end{array}$ & $\begin{array}{c}0.023^{*} \\
(0.014)\end{array}$ \\
\hline $\mathbb{E}[\operatorname{Pr}($ overweight $) \mid x]$ & 0.161 & 0.132 & 0.120 & 0.197 & 0.151 & 0.152 \\
\hline $\mathrm{N}$ & 10,143 & 10,481 & 8,285 & 7,871 & 6,600 & 6,600 \\
\hline
\end{tabular}


Table B17(b): Individual healthy behaviours and overweight in children across ages cont.

\begin{tabular}{|c|c|c|c|c|c|c|}
\hline & & & & & \multicolumn{2}{|c|}{ (5)-(6) Age 14} \\
\hline & $\begin{array}{c}\text { (1) } \\
\text { Age } 3\end{array}$ & $\begin{array}{c}\text { (2) } \\
\text { Age } 5\end{array}$ & $\begin{array}{c}(3) \\
\text { Age } 7\end{array}$ & $\begin{array}{c}(4) \\
\text { Age } 11\end{array}$ & $\begin{array}{l}\text { Parental weight } \\
\text { constant }\end{array}$ & $\begin{array}{l}\text { Parental weight } \\
\text { predicted }\end{array}$ \\
\hline Female & $\begin{array}{l}0.063^{* * *} \\
(0.009)\end{array}$ & $\begin{array}{l}0.092^{* * *} \\
(0.009)\end{array}$ & $\begin{array}{l}0.097^{* * *} \\
(0.009)\end{array}$ & $\begin{array}{l}0.064^{* * *} \\
(0.011)\end{array}$ & $\begin{array}{l}0.043^{* * *} \\
(0.012)\end{array}$ & $\begin{array}{l}0.044^{* * *} \\
(0.012)\end{array}$ \\
\hline \multicolumn{7}{|l|}{ Main parent's education } \\
\hline NVQ level 1 & $\begin{array}{c}0.008 \\
(0.021)\end{array}$ & $\begin{array}{c}0.018 \\
(0.020)\end{array}$ & $\begin{array}{l}-0.020 \\
(0.022)\end{array}$ & $\begin{array}{c}-0.011 \\
(0.026)\end{array}$ & $\begin{array}{l}-0.033 \\
(0.028)\end{array}$ & $\begin{array}{l}-0.039 \\
(0.029)\end{array}$ \\
\hline NVQ level 2 & $\begin{array}{c}-0.004 \\
(0.017)\end{array}$ & $\begin{array}{c}-0.008 \\
(0.015)\end{array}$ & $\begin{array}{c}-0.013 \\
(0.018)\end{array}$ & $\begin{array}{c}-0.002 \\
(0.021)\end{array}$ & $\begin{array}{c}-0.014 \\
(0.024)\end{array}$ & $\begin{array}{c}-0.017 \\
(0.024)\end{array}$ \\
\hline NVQ level 3 & $\begin{array}{c}-0.005 \\
(0.019)\end{array}$ & $\begin{array}{c}-0.002 \\
(0.017)\end{array}$ & $\begin{array}{c}-0.029 \\
(0.020)\end{array}$ & $\begin{array}{c}-0.020 \\
(0.024)\end{array}$ & $\begin{array}{l}-0.037 \\
(0.026)\end{array}$ & $\begin{array}{l}-0.041 \\
(0.026)\end{array}$ \\
\hline NVQ level 4 & $\begin{array}{c}0.000 \\
(0.018)\end{array}$ & $\begin{array}{c}0.002 \\
(0.016)\end{array}$ & $\begin{array}{c}-0.024 \\
(0.019)\end{array}$ & $\begin{array}{c}-0.007 \\
(0.024)\end{array}$ & $\begin{array}{l}-0.017 \\
(0.025)\end{array}$ & $\begin{array}{l}-0.021 \\
(0.025)\end{array}$ \\
\hline NVQ level 5 & $\begin{array}{l}0.070^{* *} \\
(0.030)\end{array}$ & $\begin{array}{c}0.002 \\
(0.025)\end{array}$ & $\begin{array}{c}-0.030 \\
(0.027)\end{array}$ & $\begin{array}{c}-0.011 \\
(0.035)\end{array}$ & $\begin{array}{r}-0.064^{*} \\
(0.032)\end{array}$ & $\begin{array}{l}-0.068^{* *} \\
(0.033)\end{array}$ \\
\hline Child long-term illness & $\begin{array}{c}0.016 \\
(0.012)\end{array}$ & $\begin{array}{c}-0.016 \\
(0.011)\end{array}$ & $\begin{array}{c}-0.004 \\
(0.012)\end{array}$ & $\begin{array}{c}0.000 \\
(0.017)\end{array}$ & $\begin{array}{c}0.005 \\
(0.021)\end{array}$ & $\begin{array}{c}0.007 \\
(0.021)\end{array}$ \\
\hline Health conditions & $\begin{array}{c}0.004 \\
(0.004)\end{array}$ & $\begin{array}{c}0.006 \\
(0.004)\end{array}$ & $\begin{array}{c}0.005 \\
(0.004)\end{array}$ & $\begin{array}{c}0.001 \\
(0.005)\end{array}$ & $\begin{array}{c}0.004 \\
(0.010)\end{array}$ & $\begin{array}{c}0.003 \\
(0.010)\end{array}$ \\
\hline Main parent long-term illness & $\begin{array}{c}-0.015 \\
(0.010)\end{array}$ & $\begin{array}{c}-0.003 \\
(0.010)\end{array}$ & $\begin{array}{c}0.016 \\
(0.011)\end{array}$ & $\begin{array}{c}0.005 \\
(0.013)\end{array}$ & $\begin{array}{l}-0.010 \\
(0.014)\end{array}$ & $\begin{array}{l}-0.008 \\
(0.014)\end{array}$ \\
\hline No. of siblings & $\begin{array}{c}0.003 \\
(0.005)\end{array}$ & $\begin{array}{c}-0.005 \\
(0.004)\end{array}$ & $\begin{array}{c}-0.011^{* *} \\
(0.005)\end{array}$ & $\begin{array}{l}-0.019^{* * *} \\
(0.006)\end{array}$ & $\begin{array}{l}-0.022^{* * *} \\
(0.006)\end{array}$ & $\begin{array}{l}-0.022^{* * *} \\
(0.006)\end{array}$ \\
\hline Birthweight & $\begin{array}{l}0.109^{* * *} \\
(0.009)\end{array}$ & $\begin{array}{l}0.090^{* * *} \\
(0.008)\end{array}$ & $\begin{array}{l}0.058^{* * *} \\
(0.008)\end{array}$ & $\begin{array}{l}0.032^{* * *} \\
(0.010)\end{array}$ & $\begin{array}{l}0.024^{* *} \\
(0.010)\end{array}$ & $\begin{array}{l}0.027^{* * *} \\
(0.010)\end{array}$ \\
\hline Weight gain 9 months-3 (kg) & $\begin{array}{l}0.077^{* * *} \\
(0.005)\end{array}$ & $\begin{array}{l}0.068^{* * *} \\
(0.004)\end{array}$ & $\begin{array}{l}0.045^{* * *} \\
(0.005)\end{array}$ & $\begin{array}{l}0.036^{* * *} \\
(0.005)\end{array}$ & $\begin{array}{l}0.029^{* * *} \\
(0.005)\end{array}$ & $\begin{array}{l}0.029^{* * *} \\
(0.005)\end{array}$ \\
\hline \multicolumn{7}{|l|}{ Ethnicity } \\
\hline Mixed & $\begin{array}{c}0.032 \\
(0.052)\end{array}$ & $\begin{array}{c}-0.009 \\
(0.040)\end{array}$ & $\begin{array}{c}-0.019 \\
(0.046)\end{array}$ & $\begin{array}{c}0.048 \\
(0.038)\end{array}$ & $\begin{array}{c}-0.013 \\
(0.054)\end{array}$ & $\begin{array}{c}-0.019 \\
(0.051)\end{array}$ \\
\hline Indian & $\begin{array}{l}-0.090^{* * *} \\
(0.026)\end{array}$ & $\begin{array}{c}0.020 \\
(0.038)\end{array}$ & $\begin{array}{c}0.048 \\
(0.039)\end{array}$ & $\begin{array}{c}0.055 \\
(0.041)\end{array}$ & $\begin{array}{c}-0.010 \\
(0.040)\end{array}$ & $\begin{array}{l}-0.010 \\
(0.042)\end{array}$ \\
\hline Pakistani and Bangladeshi & $\begin{array}{c}-0.022 \\
(0.023)\end{array}$ & $\begin{array}{c}-0.011 \\
(0.023)\end{array}$ & $\begin{array}{c}-0.003 \\
(0.026)\end{array}$ & $\begin{array}{l}0.063^{* *} \\
(0.033)\end{array}$ & $\begin{array}{c}0.002 \\
(0.030)\end{array}$ & $\begin{array}{c}-0.000 \\
(0.030)\end{array}$ \\
\hline Black or Black British & $\begin{array}{c}0.014 \\
(0.032)\end{array}$ & $\begin{array}{l}0.066^{* *} \\
(0.032)\end{array}$ & $\begin{array}{c}0.078^{* *} \\
(0.037)\end{array}$ & $\begin{array}{l}0.109^{* * * *} \\
(0.041)\end{array}$ & $\begin{array}{c}0.044 \\
(0.038)\end{array}$ & $\begin{array}{c}0.043 \\
(0.038)\end{array}$ \\
\hline Other Ethnic group (inc Chinese,Other) & $\begin{array}{c}-0.014 \\
(0.040)\end{array}$ & $\begin{array}{c}-0.041 \\
(0.032)\end{array}$ & $\begin{array}{c}-0.028 \\
(0.040)\end{array}$ & $\begin{array}{c}-0.000 \\
(0.064)\end{array}$ & $\begin{array}{c}0.056 \\
(0.067)\end{array}$ & $\begin{array}{c}0.049 \\
(0.067)\end{array}$ \\
\hline $\mathbb{E}[\operatorname{Pr}($ overweight $) \mid \boldsymbol{x}]$ & 0.161 & 0.132 & 0.120 & 0.197 & 0.151 & 0.152 \\
\hline $\mathrm{N}$ & 10,143 & 10,481 & 8,285 & 7,871 & 6,600 & 6,600 \\
\hline
\end{tabular}

Note: $* * *$ and $* * *$ denote statistical significance it $10 \%, 5 \%$ and $1 \%$ respectively. The outcome in each column is whether or not a child is overweight, defined using the the IOTF cutoffs (Table A1). The effects reported are marginal effects obtained after estimating Equation 4 fixing the independent variables at their sample mean. The MCS data do not contain parents' BMI at age 14, so columns 5 and 6 use BMI from age 11 or as predicted to define obesity. All observations are adjusted for the probability of attrition and being sampled, see (Hansen et al., 2014). The omitted categories are income: highest quintile; parents' education: no qualifications; ethnicity: white. Female is an indicator of whether a child is female. Not all healthy behaviours on which we have measures are available at all ages so each columns include those that are. Appendix Table A6(a) describes how indicators of healthy behaviours were constructed. $\mathbb{E}[\operatorname{Pr}($ overweight $) \mid \boldsymbol{x}]$ represents estimated the conditional expectation of a child being overweight. The main parent is the mother for over $99 \%$ of children at 9 months. Ns differ across columns because of missing data. 
Table B18(a): Individual healthy behaviours and obesity in children across ages

\begin{tabular}{|c|c|c|c|c|c|c|}
\hline & & & & & \multicolumn{2}{|c|}{ (5)-(6) Age 14} \\
\hline & $\begin{array}{c}(1) \\
\text { Age } 3\end{array}$ & $\begin{array}{c}(2) \\
\text { Age } 5\end{array}$ & $\begin{array}{c}(3) \\
\text { Age } 7\end{array}$ & $\begin{array}{c}(4) \\
\text { Age } 11\end{array}$ & $\begin{array}{l}\text { Parental weight } \\
\text { constant }\end{array}$ & $\begin{array}{l}\text { Parental weight } \\
\text { predicted }\end{array}$ \\
\hline Main parent overweight & $\begin{array}{l}0.021^{\text {*** }} \\
(0.006)\end{array}$ & $\begin{array}{l}0.026^{* * *} \\
(0.006)\end{array}$ & $\begin{array}{l}0.029^{* * *} \\
(0.006)\end{array}$ & $\begin{array}{l}0.035^{* * *} \\
(0.007)\end{array}$ & $\begin{array}{l}0.025^{* * *} \\
(0.007)\end{array}$ & $\begin{array}{l}0.025^{* * *} \\
(0.006)\end{array}$ \\
\hline Main parent obese/morbidly obese & $\begin{array}{l}0.048^{* * *} \\
(0.008)\end{array}$ & $\begin{array}{l}0.065^{* * *} \\
(0.009)\end{array}$ & $\begin{array}{l}0.084^{* * *} \\
(0.010)\end{array}$ & $\begin{array}{l}0.080^{* * *} \\
(0.010)\end{array}$ & $\begin{array}{l}0.098^{* * *} \\
(0.011)\end{array}$ & $\begin{array}{l}0.093^{* * *} \\
(0.010)\end{array}$ \\
\hline \multicolumn{7}{|l|}{ Income quintiles } \\
\hline Lowest quintile & $\begin{array}{l}0.021^{* *} \\
(0.010)\end{array}$ & $\begin{array}{c}0.015 \\
(0.009)\end{array}$ & $\begin{array}{c}0.010 \\
(0.010)\end{array}$ & $\begin{array}{l}0.033^{* *} \\
(0.014)\end{array}$ & $\begin{array}{l}0.072^{* * *} \\
(0.019)\end{array}$ & $\begin{array}{l}0.073^{* * *} \\
(0.019)\end{array}$ \\
\hline Second quintile & $\begin{array}{c}0.014^{*} \\
(0.008)\end{array}$ & $\begin{array}{c}0.010 \\
(0.009)\end{array}$ & $\begin{array}{c}0.012 \\
(0.009)\end{array}$ & $\begin{array}{l}0.035^{* * *} \\
(0.011)\end{array}$ & $\begin{array}{l}0.027^{* *} \\
(0.011)\end{array}$ & $\begin{array}{l}0.028^{* *} \\
(0.011)\end{array}$ \\
\hline Third quintile & $\begin{array}{c}0.004 \\
(0.007)\end{array}$ & $\begin{array}{c}0.005 \\
(0.008)\end{array}$ & $\begin{array}{c}0.002 \\
(0.008)\end{array}$ & $\begin{array}{c}0.018^{*} \\
(0.010)\end{array}$ & $\begin{array}{r}0.017^{*} \\
(0.009)\end{array}$ & $\begin{array}{c}0.018^{*} \\
(0.009)\end{array}$ \\
\hline Fourth quintile & $\begin{array}{c}0.015^{*} \\
(0.007)\end{array}$ & $\begin{array}{c}0.006 \\
(0.008)\end{array}$ & $\begin{array}{c}0.003 \\
(0.008)\end{array}$ & $\begin{array}{c}0.008 \\
(0.008)\end{array}$ & $\begin{array}{c}0.007 \\
(0.008)\end{array}$ & $\begin{array}{c}0.007 \\
(0.008)\end{array}$ \\
\hline \multicolumn{7}{|l|}{ Healthy behaviours } \\
\hline Fruit/veg once a day & $\begin{array}{c}0.005 \\
(0.014)\end{array}$ & $\begin{array}{c}-0.004 \\
(0.005)\end{array}$ & $\begin{array}{c}0.007 \\
(0.006)\end{array}$ & $\begin{array}{c}-0.014^{* *} \\
(0.006)\end{array}$ & $\begin{array}{l}-0.000 \\
(0.008)\end{array}$ & $\begin{array}{l}-0.001 \\
(0.008)\end{array}$ \\
\hline Regular meals & $\begin{array}{c}0.005 \\
(0.005)\end{array}$ & $\begin{array}{c}0.004 \\
(0.005)\end{array}$ & & & & \\
\hline Physically active games once a week & $\begin{array}{c}0.011^{*} \\
(0.006)\end{array}$ & $\begin{array}{c}0.010^{*} \\
(0.005)\end{array}$ & $\begin{array}{c}0.010^{*} \\
(0.006)\end{array}$ & $\begin{array}{c}-0.014^{* *} \\
(0.006)\end{array}$ & & \\
\hline Sport once a week & & $\begin{array}{c}-0.008 \\
(0.005)\end{array}$ & $\begin{array}{c}-0.016^{*} \\
(0.009)\end{array}$ & $\begin{array}{c}-0.028^{* * *} \\
(0.012)\end{array}$ & & \\
\hline Sport with child once a week & & $\begin{array}{c}-0.002 \\
(0.005)\end{array}$ & $\begin{array}{c}0.001 \\
(0.006)\end{array}$ & $\begin{array}{c}0.012 \\
(0.013)\end{array}$ & & \\
\hline Breakfast every day & & & & $\begin{array}{c}-0.003 \\
(0.008)\end{array}$ & $\begin{array}{c}-0.029^{* * *} \\
(0.007)\end{array}$ & $\begin{array}{c}-0.029^{* * *} \\
(0.007)\end{array}$ \\
\hline Art. sweetened drinks less than once a week & & & & $\begin{array}{c}-0.029^{* * *} \\
(0.007)\end{array}$ & $\begin{array}{c}-0.018^{*} \\
(0.010)\end{array}$ & $\begin{array}{c}-0.018^{* *} \\
(0.010)\end{array}$ \\
\hline Sweetened drinks less than once a week & & & & $\begin{array}{c}0.001 \\
(0.006)\end{array}$ & $\begin{array}{c}0.006 \\
(0.008)\end{array}$ & $\begin{array}{c}0.006 \\
(0.008)\end{array}$ \\
\hline Fast food less than once a week & & & & & $\begin{array}{c}0.002 \\
(0.008)\end{array}$ & $\begin{array}{c}0.003 \\
(0.008)\end{array}$ \\
\hline $\mathbb{E}[\operatorname{Pr}($ obese $) \mid x]$ & 0.038 & 0.039 & 0.039 & 0.040 & 0.037 & 0.037 \\
\hline $\mathrm{N}$ & 10,714 & 11,115 & 8,942 & 8,408 & 6,985 & 6,985 \\
\hline
\end{tabular}


Table B18(b): Individual healthy behaviours and obesity in children across ages cont.

\begin{tabular}{|c|c|c|c|c|c|c|}
\hline & \multirow[b]{2}{*}{$\begin{array}{c}\text { (1) } \\
\text { Age } 3\end{array}$} & \multirow[b]{2}{*}{$\begin{array}{c}\text { (2) } \\
\text { Age } 5\end{array}$} & \multirow[b]{2}{*}{$\begin{array}{c}\text { (3) } \\
\text { Age } 7\end{array}$} & \multirow[b]{2}{*}{$\begin{array}{l}(4) \\
\text { Age } 11\end{array}$} & \multicolumn{2}{|c|}{ (5)-(6) Age 14} \\
\hline & & & & & $\begin{array}{l}\text { Parental weight } \\
\text { constant }\end{array}$ & $\begin{array}{l}\text { Parental weight } \\
\text { predicted }\end{array}$ \\
\hline Female & $\begin{array}{l}0.023^{* * *} \\
(0.005)\end{array}$ & $\begin{array}{l}0.018^{* * *} \\
(0.005)\end{array}$ & $\begin{array}{l}0.029^{* * *} \\
(0.006)\end{array}$ & $\begin{array}{l}0.022^{* * * *} \\
(0.007)\end{array}$ & $\begin{array}{l}0.019^{* * *} \\
(0.007)\end{array}$ & $\begin{array}{l}0.018^{* * *} \\
(0.007)\end{array}$ \\
\hline \multicolumn{7}{|l|}{ Main parent's education } \\
\hline NVQ level 1 & $\begin{array}{c}0.006 \\
(0.012)\end{array}$ & $\begin{array}{l}-0.002 \\
(0.012)\end{array}$ & $\begin{array}{c}0.002 \\
(0.013)\end{array}$ & $\begin{array}{c}0.006 \\
(0.015)\end{array}$ & $\begin{array}{c}0.017 \\
(0.015)\end{array}$ & $\begin{array}{c}0.016 \\
(0.015)\end{array}$ \\
\hline NVQ level 2 & $\begin{array}{c}-0.011 \\
(0.009)\end{array}$ & $\begin{array}{c}-0.006 \\
(0.009)\end{array}$ & $\begin{array}{l}-0.000 \\
(0.011)\end{array}$ & $\begin{array}{c}-0.016 \\
(0.012)\end{array}$ & $\begin{array}{c}0.012 \\
(0.012)\end{array}$ & $\begin{array}{c}0.011 \\
(0.012)\end{array}$ \\
\hline NVQ level 3 & $\begin{array}{c}-0.015 \\
(0.010)\end{array}$ & $\begin{array}{c}-0.022^{* *} \\
(0.010)\end{array}$ & $\begin{array}{l}-0.006 \\
(0.012)\end{array}$ & $\begin{array}{c}-0.031^{* * *} \\
(0.012)\end{array}$ & $\begin{array}{c}0.008 \\
(0.014)\end{array}$ & $\begin{array}{c}0.008 \\
(0.014)\end{array}$ \\
\hline NVQ level 4 & $\begin{array}{c}-0.009 \\
(0.009)\end{array}$ & $\begin{array}{c}-0.022^{* *} \\
(0.009)\end{array}$ & $\begin{array}{r}-0.019^{*} \\
(0.011)\end{array}$ & $\begin{array}{c}-0.017 \\
(0.013)\end{array}$ & $\begin{array}{l}-0.004 \\
(0.012)\end{array}$ & $\begin{array}{c}-0.004 \\
(0.012)\end{array}$ \\
\hline NVQ level 5 & $\begin{array}{c}0.006 \\
(0.018)\end{array}$ & $\begin{array}{c}-0.033^{* *} \\
(0.013)\end{array}$ & $\begin{array}{l}-0.040^{* * *} \\
(0.013)\end{array}$ & $\begin{array}{c}-0.044^{* *} \\
(0.017)\end{array}$ & $\begin{array}{l}-0.013 \\
(0.018)\end{array}$ & $\begin{array}{l}-0.013 \\
(0.018)\end{array}$ \\
\hline Child long-term illness & $\begin{array}{r}-0.012^{*} \\
(0.006)\end{array}$ & $\begin{array}{l}0.017^{* *} \\
(0.007)\end{array}$ & $\begin{array}{c}0.002 \\
(0.007)\end{array}$ & $\begin{array}{c}0.000 \\
(0.009)\end{array}$ & $\begin{array}{c}0.006 \\
(0.012)\end{array}$ & $\begin{array}{c}0.007 \\
(0.012)\end{array}$ \\
\hline Health conditions & $\begin{array}{c}0.002 \\
(0.002)\end{array}$ & $\begin{array}{c}0.001 \\
(0.002)\end{array}$ & $\begin{array}{c}0.005^{* *} \\
(0.002)\end{array}$ & $\begin{array}{c}0.005^{* *} \\
(0.002)\end{array}$ & $\begin{array}{c}0.005 \\
(0.004)\end{array}$ & $\begin{array}{c}0.004 \\
(0.005)\end{array}$ \\
\hline Main parent long-term illness & $\begin{array}{c}-0.001 \\
(0.006)\end{array}$ & $\begin{array}{r}0.010^{*} \\
(0.006)\end{array}$ & $\begin{array}{c}0.007 \\
(0.007)\end{array}$ & $\begin{array}{l}0.015^{* *} \\
(0.008)\end{array}$ & $\begin{array}{c}0.009 \\
(0.008)\end{array}$ & $\begin{array}{c}0.010 \\
(0.008)\end{array}$ \\
\hline No. of siblings & $\begin{array}{c}0.000 \\
(0.002)\end{array}$ & $\begin{array}{l}-0.007^{* * *} \\
(0.002)\end{array}$ & $\begin{array}{l}-0.004 \\
(0.003)\end{array}$ & $\begin{array}{l}-0.010^{* * *} \\
(0.003)\end{array}$ & $\begin{array}{l}-0.010^{* * *} \\
(0.004)\end{array}$ & $\begin{array}{l}-0.009^{* *} \\
(0.004)\end{array}$ \\
\hline Birthweight & $\begin{array}{l}0.014^{* * *} \\
(0.005)\end{array}$ & $\begin{array}{l}0.026^{* * *} \\
(0.005)\end{array}$ & $\begin{array}{l}0.013^{* * *} \\
(0.005)\end{array}$ & $\begin{array}{l}0.019^{* * *} \\
(0.005)\end{array}$ & $\begin{array}{l}0.029^{* * *} \\
(0.006)\end{array}$ & $\begin{array}{l}0.031^{* * *} \\
(0.006)\end{array}$ \\
\hline Weight gain 9 months-3 (kg) & $\begin{array}{l}0.024^{* * *} \\
(0.002)\end{array}$ & $\begin{array}{l}0.018^{* * *} \\
(0.002)\end{array}$ & $\begin{array}{l}0.018^{* * *} \\
(0.002)\end{array}$ & $\begin{array}{l}0.014^{* * * *} \\
(0.003)\end{array}$ & $\begin{array}{l}0.012^{* * *} \\
(0.003)\end{array}$ & $\begin{array}{l}0.012^{* * *} \\
(0.003)\end{array}$ \\
\hline \multicolumn{7}{|l|}{ Ethnicity } \\
\hline Mixed & $\begin{array}{l}0.047^{* *} \\
(0.030)\end{array}$ & $\begin{array}{c}0.011 \\
(0.024)\end{array}$ & $\begin{array}{l}-0.021 \\
(0.022)\end{array}$ & $\begin{array}{c}0.039^{* *} \\
(0.023)\end{array}$ & $\begin{array}{l}-0.030 \\
(0.018)\end{array}$ & $\begin{array}{l}-0.030 \\
(0.018)\end{array}$ \\
\hline Indian & $\begin{array}{c}-0.002 \\
(0.020)\end{array}$ & $\begin{array}{c}0.015 \\
(0.024)\end{array}$ & $\begin{array}{c}0.019 \\
(0.026)\end{array}$ & $\begin{array}{c}-0.031^{*} \\
(0.012)\end{array}$ & $\begin{array}{c}0.004 \\
(0.026)\end{array}$ & $\begin{array}{c}0.003 \\
(0.025)\end{array}$ \\
\hline Pakistani and Bangladeshi & $\begin{array}{c}0.005 \\
(0.012)\end{array}$ & $\begin{array}{l}0.038^{* * *} \\
(0.016)\end{array}$ & $\begin{array}{r}0.027^{*} \\
(0.016)\end{array}$ & $\begin{array}{c}0.028^{*} \\
(0.020)\end{array}$ & $\begin{array}{c}0.016 \\
(0.019)\end{array}$ & $\begin{array}{c}0.016 \\
(0.019)\end{array}$ \\
\hline Black or Black British & $\begin{array}{l}0.051^{* * *} \\
(0.021)\end{array}$ & $\begin{array}{l}0.058^{* * *} \\
(0.021)\end{array}$ & $\begin{array}{l}0.094^{* * *} \\
(0.026)\end{array}$ & $\begin{array}{l}0.052^{* * *} \\
(0.024)\end{array}$ & $\begin{array}{c}0.020 \\
(0.021)\end{array}$ & $\begin{array}{c}0.020 \\
(0.022)\end{array}$ \\
\hline Other Ethnic group (inc Chinese,Other) & $\begin{array}{c}0.021 \\
(0.026)\end{array}$ & $\begin{array}{c}0.019 \\
(0.028)\end{array}$ & $\begin{array}{c}0.015 \\
(0.032)\end{array}$ & $\begin{array}{c}0.003 \\
(0.030)\end{array}$ & $\begin{array}{c}-0.014 \\
(0.024)\end{array}$ & $\begin{array}{c}-0.015 \\
(0.023)\end{array}$ \\
\hline $\mathbb{E}[\operatorname{Pr}($ obese $) \mid \boldsymbol{x}]$ & $\begin{array}{r}0.038 \\
10714\end{array}$ & $\begin{array}{r}0.039 \\
11115\end{array}$ & $\begin{array}{l}0.039 \\
8047\end{array}$ & 0.040 & $\begin{array}{l}0.037 \\
6085\end{array}$ & $\begin{array}{l}0.037 \\
6085\end{array}$ \\
\hline 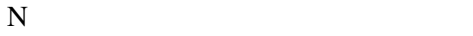 & 10,714 & 11,115 & 8,942 & 8,408 & 6,985 & 6,985 \\
\hline
\end{tabular}

Note: $* * *$ and $* * *$ denote statistical significance it $10 \%, 5 \%$ and $1 \%$ respectively. The outcome in each column is whether or not a child is overweight, defined using the the IOTF cutoffs (Table A1). The effects reported are marginal effects obtained after estimating Equation 4 fixing the independent variables at their sample mean. The MCS data do not contain parents' BMI at age 14, so columns 5 and 6 use BMI from age 11 or as predicted to define obesity. All observations are adjusted for the probability of attrition and being sampled, see (Hansen et al., 2014). The omitted categories are income: highest quintile; parents' education: no qualifications; ethnicity: white. Female is an indicator of whether a child is female. $\mathbb{E}[\operatorname{Pr}($ overweight $) \mid \boldsymbol{x}]$ represents estimated the conditional expectation of a child being overweight. The main parent is the mother for over $99 \%$ of children at 9 months. Ns differ across columns because of missing data. 
Table B19(a): Individual healthy behaviours and overweight or obesity in children across ages

\begin{tabular}{|c|c|c|c|c|c|c|}
\hline & & & & & \multicolumn{2}{|c|}{ (5)-(6) Age 14} \\
\hline & $\begin{array}{c}(1) \\
\text { Age } 3\end{array}$ & $\begin{array}{c}\text { (2) } \\
\text { Age } 5\end{array}$ & $\begin{array}{c}\text { (3) } \\
\text { Age } 7\end{array}$ & $\begin{array}{c}(4) \\
\text { Age } 11\end{array}$ & $\begin{array}{l}\text { Parental weight } \\
\text { constant }\end{array}$ & $\begin{array}{c}\text { Parental weight } \\
\text { predicted }\end{array}$ \\
\hline Main parent overweight & $\begin{array}{l}0.036^{* * *} \\
(0.011)\end{array}$ & $\begin{array}{l}0.078^{* * *} \\
(0.010)\end{array}$ & $\begin{array}{l}0.085^{* * *} \\
(0.011)\end{array}$ & $\begin{array}{l}0.120^{* * *} \\
(0.013)\end{array}$ & $\begin{array}{l}0.110^{* * *} \\
(0.014)\end{array}$ & $\begin{array}{l}0.084^{* * *} \\
(0.013)\end{array}$ \\
\hline Main parent obese/morbidly obese & $\begin{array}{l}0.091^{* * *} \\
(0.014)\end{array}$ & $\begin{array}{l}0.165^{* * *} \\
(0.014)\end{array}$ & $\begin{array}{l}0.155^{* * *} \\
(0.015)\end{array}$ & $\begin{array}{l}0.241^{* * *} \\
(0.016)\end{array}$ & $\begin{array}{l}0.232^{* * *} \\
(0.018)\end{array}$ & $\begin{array}{l}0.230^{* * *} \\
(0.017)\end{array}$ \\
\hline \multicolumn{7}{|l|}{ Income quintiles } \\
\hline Lowest quintile & $\begin{array}{l}0.055^{* * *} \\
(0.017)\end{array}$ & $\begin{array}{l}0.035^{* *} \\
(0.016)\end{array}$ & $\begin{array}{c}0.014 \\
(0.018)\end{array}$ & $\begin{array}{c}0.044^{*} \\
(0.026)\end{array}$ & $\begin{array}{l}0.138^{* * *} \\
(0.029)\end{array}$ & $\begin{array}{l}0.140^{* * *} \\
(0.029)\end{array}$ \\
\hline Second quintile & $\begin{array}{l}0.043^{* * *} \\
(0.015)\end{array}$ & $\begin{array}{c}0.016 \\
(0.015)\end{array}$ & $\begin{array}{c}0.020 \\
(0.016)\end{array}$ & $\begin{array}{l}0.065^{* * *} \\
(0.021)\end{array}$ & $\begin{array}{l}0.069^{* * *} \\
(0.022)\end{array}$ & $\begin{array}{l}0.068^{* * *} \\
(0.022)\end{array}$ \\
\hline Third quintile & $\begin{array}{l}0.030^{* *} \\
(0.014)\end{array}$ & $\begin{array}{c}0.000 \\
(0.013)\end{array}$ & $\begin{array}{c}0.008 \\
(0.015)\end{array}$ & $\begin{array}{l}0.061^{* * *} \\
(0.018)\end{array}$ & $\begin{array}{l}0.050^{* * *} \\
(0.018)\end{array}$ & $\begin{array}{l}0.052^{* * *} \\
(0.017)\end{array}$ \\
\hline Fourth quintile & $\begin{array}{l}0.032^{* *} \\
(0.013)\end{array}$ & $\begin{array}{l}0.026^{* *} \\
(0.013)\end{array}$ & $\begin{array}{c}0.002 \\
(0.014)\end{array}$ & $\begin{array}{c}0.022 \\
(0.016)\end{array}$ & $\begin{array}{c}0.013 \\
(0.015)\end{array}$ & $\begin{array}{c}0.013 \\
(0.015)\end{array}$ \\
\hline \multicolumn{7}{|l|}{ Healthy behaviours } \\
\hline Fruit/veg once a day & $\begin{array}{c}0.018 \\
(0.025)\end{array}$ & $\begin{array}{c}0.006 \\
(0.009)\end{array}$ & $\begin{array}{c}0.008 \\
(0.009)\end{array}$ & $\begin{array}{c}-0.003 \\
(0.011)\end{array}$ & $\begin{array}{c}0.012 \\
(0.014)\end{array}$ & $\begin{array}{c}0.011 \\
(0.014)\end{array}$ \\
\hline Regular meals & $\begin{array}{c}-0.000 \\
(0.009)\end{array}$ & $\begin{array}{c}0.007 \\
(0.009)\end{array}$ & & & & \\
\hline Physically active games once a week & $\begin{array}{c}0.006 \\
(0.011)\end{array}$ & $\begin{array}{c}0.004 \\
(0.009)\end{array}$ & $\begin{array}{c}0.007 \\
(0.009)\end{array}$ & $\begin{array}{c}-0.039^{* * *} \\
(0.012)\end{array}$ & & \\
\hline Sport once a week & & $\begin{array}{c}-0.007 \\
(0.009)\end{array}$ & $\begin{array}{c}-0.036^{* *} \\
(0.017)\end{array}$ & $\begin{array}{c}-0.051^{* * *} \\
(0.020)\end{array}$ & & \\
\hline Sport with child once a week & & $\begin{array}{c}0.003 \\
(0.010)\end{array}$ & $\begin{array}{c}0.001 \\
(0.010)\end{array}$ & $\begin{array}{c}0.001 \\
(0.021)\end{array}$ & & \\
\hline Breakfast every day & & & & $\begin{array}{c}-0.033^{* *} \\
(0.017)\end{array}$ & $\begin{array}{c}-0.055^{* * *} \\
(0.013)\end{array}$ & $\begin{array}{c}-0.057^{* * *} \\
(0.013)\end{array}$ \\
\hline Art. sweetened drinks less than once a week & & & & $\begin{array}{c}-0.031^{* * *} \\
(0.012)\end{array}$ & $\begin{array}{c}-0.081^{* * *} \\
(0.017)\end{array}$ & $\begin{array}{c}-0.084^{* * *} \\
(0.017)\end{array}$ \\
\hline Sweetened drinks less than once a week & & & & $\begin{array}{r}-0.004 \\
(0.012)\end{array}$ & $\begin{array}{c}0.030^{* *} \\
(0.014)\end{array}$ & $\begin{array}{c}0.029^{*} \\
(0.014)\end{array}$ \\
\hline Fast food less than once a week & & & & & $\begin{array}{c}0.022 \\
(0.014)\end{array}$ & $\begin{array}{c}0.023^{*} \\
(0.014)\end{array}$ \\
\hline $\mathbb{E}[\operatorname{Pr}($ overweight $\cup$ obese $) \mid x]$ & 0.199 & 0.174 & 0.159 & 0.240 & 0.192 & 0.193 \\
\hline $\mathrm{N}$ & 10,714 & 11,115 & 8,942 & 8,408 & 6,985 & 6,985 \\
\hline
\end{tabular}


Table B19(b): Individual healthy behaviours and overweight or obesity in children across ages cont.

\begin{tabular}{|c|c|c|c|c|c|c|}
\hline & & & & & \multicolumn{2}{|c|}{ (5)-(6) Age 14} \\
\hline & $\begin{array}{c}(1) \\
\text { Age } 3\end{array}$ & $\begin{array}{c}\text { (2) } \\
\text { Age } 5\end{array}$ & $\begin{array}{c}\text { (3) } \\
\text { Age } 7\end{array}$ & $\begin{array}{c}(4) \\
\text { Age } 11\end{array}$ & $\begin{array}{l}\text { Parental weight } \\
\text { constant }\end{array}$ & $\begin{array}{l}\text { Parental weight } \\
\text { predicted }\end{array}$ \\
\hline Female & $\begin{array}{l}0.076^{* * *} \\
(0.010)\end{array}$ & $\begin{array}{l}0.099^{* * *} \\
(0.009)\end{array}$ & $\begin{array}{l}0.119^{* * *} \\
(0.010)\end{array}$ & $\begin{array}{l}0.075^{* * *} \\
(0.011)\end{array}$ & $\begin{array}{l}0.054^{* * *} \\
(0.013)\end{array}$ & $\begin{array}{l}0.055^{* * *} \\
(0.013)\end{array}$ \\
\hline \multicolumn{7}{|l|}{ Main parent's education } \\
\hline NVQ level 1 & $\begin{array}{c}0.010 \\
(0.022)\end{array}$ & $\begin{array}{c}0.013 \\
(0.021)\end{array}$ & $\begin{array}{l}-0.019 \\
(0.023)\end{array}$ & $\begin{array}{c}-0.007 \\
(0.026)\end{array}$ & $\begin{array}{l}-0.017 \\
(0.029)\end{array}$ & $\begin{array}{l}-0.023 \\
(0.029)\end{array}$ \\
\hline NVQ level 2 & $\begin{array}{c}-0.015 \\
(0.017)\end{array}$ & $\begin{array}{c}-0.012 \\
(0.016)\end{array}$ & $\begin{array}{c}-0.012 \\
(0.019)\end{array}$ & $\begin{array}{c}-0.016 \\
(0.021)\end{array}$ & $\begin{array}{c}-0.004 \\
(0.024)\end{array}$ & $\begin{array}{l}-0.008 \\
(0.024)\end{array}$ \\
\hline NVQ level 3 & $\begin{array}{c}-0.017 \\
(0.019)\end{array}$ & $\begin{array}{c}-0.019 \\
(0.018)\end{array}$ & $\begin{array}{l}-0.031 \\
(0.021)\end{array}$ & $\begin{array}{r}-0.042^{*} \\
(0.024)\end{array}$ & $\begin{array}{l}-0.030 \\
(0.026)\end{array}$ & $\begin{array}{l}-0.034 \\
(0.026)\end{array}$ \\
\hline NVQ level 4 & $\begin{array}{c}-0.009 \\
(0.018)\end{array}$ & $\begin{array}{c}-0.017 \\
(0.017)\end{array}$ & $\begin{array}{r}-0.036^{*} \\
(0.020)\end{array}$ & $\begin{array}{c}-0.020 \\
(0.024)\end{array}$ & $\begin{array}{l}-0.018 \\
(0.025)\end{array}$ & $\begin{array}{c}-0.022 \\
(0.025)\end{array}$ \\
\hline NVQ level 5 & $\begin{array}{l}0.066^{* *} \\
(0.031)\end{array}$ & $\begin{array}{c}-0.023 \\
(0.027)\end{array}$ & $\begin{array}{l}-0.058^{* *} \\
(0.028)\end{array}$ & $\begin{array}{c}-0.036 \\
(0.036)\end{array}$ & $\begin{array}{l}-0.070^{* *} \\
(0.033)\end{array}$ & $\begin{array}{l}-0.074^{* *} \\
(0.034)\end{array}$ \\
\hline Child long-term illness & $\begin{array}{c}0.007 \\
(0.013)\end{array}$ & $\begin{array}{c}-0.000 \\
(0.012)\end{array}$ & $\begin{array}{c}-0.002 \\
(0.013)\end{array}$ & $\begin{array}{c}0.001 \\
(0.017)\end{array}$ & $\begin{array}{c}0.010 \\
(0.022)\end{array}$ & $\begin{array}{c}0.011 \\
(0.022)\end{array}$ \\
\hline Health conditions & $\begin{array}{c}0.006 \\
(0.004)\end{array}$ & $\begin{array}{c}0.006 \\
(0.004)\end{array}$ & $\begin{array}{r}0.007^{*} \\
(0.004)\end{array}$ & $\begin{array}{c}0.005 \\
(0.005)\end{array}$ & $\begin{array}{c}0.008 \\
(0.010)\end{array}$ & $\begin{array}{c}0.007 \\
(0.010)\end{array}$ \\
\hline Main parent long-term illness & $\begin{array}{c}-0.016 \\
(0.011)\end{array}$ & $\begin{array}{c}0.005 \\
(0.010)\end{array}$ & $\begin{array}{r}0.022^{*} \\
(0.011)\end{array}$ & $\begin{array}{c}0.014 \\
(0.013)\end{array}$ & $\begin{array}{l}-0.002 \\
(0.014)\end{array}$ & $\begin{array}{c}0.000 \\
(0.014)\end{array}$ \\
\hline No. of siblings & $\begin{array}{c}0.003 \\
(0.005)\end{array}$ & $\begin{array}{l}-0.010^{* *} \\
(0.005)\end{array}$ & $\begin{array}{l}-0.013^{* * *} \\
(0.005)\end{array}$ & $\begin{array}{l}-0.026^{* * *} \\
(0.006)\end{array}$ & $\begin{array}{l}-0.027^{* * *} \\
(0.006)\end{array}$ & $\begin{array}{l}-0.027^{* * *} \\
(0.006)\end{array}$ \\
\hline Birthweight & $\begin{array}{l}0.114^{* * *} \\
(0.009)\end{array}$ & $\begin{array}{l}0.105^{* * *} \\
(0.008)\end{array}$ & $\begin{array}{l}0.065^{* * *} \\
(0.009)\end{array}$ & $\begin{array}{l}0.044^{* * *} \\
(0.010)\end{array}$ & $\begin{array}{l}0.044^{* * *} \\
(0.011)\end{array}$ & $\begin{array}{l}0.048^{* * *} \\
(0.011)\end{array}$ \\
\hline Weight gain 9 months-3 (kg) & $\begin{array}{l}0.091^{* * *} \\
(0.005)\end{array}$ & $\begin{array}{l}0.077^{* * *} \\
(0.005)\end{array}$ & $\begin{array}{l}0.057^{* * *} \\
(0.005)\end{array}$ & $\begin{array}{l}0.044^{* * *} \\
(0.005)\end{array}$ & $\begin{array}{l}0.037^{* * * *} \\
(0.005)\end{array}$ & $\begin{array}{l}0.037^{* * *} \\
(0.005)\end{array}$ \\
\hline \multicolumn{7}{|l|}{ Ethnicity } \\
\hline Mixed & $\begin{array}{c}0.059 \\
(0.049)\end{array}$ & $\begin{array}{c}-0.004 \\
(0.041)\end{array}$ & $\begin{array}{c}-0.036 \\
(0.048)\end{array}$ & $\begin{array}{l}0.070^{* *} \\
(0.037)\end{array}$ & $\begin{array}{c}-0.039 \\
(0.054)\end{array}$ & $\begin{array}{c}-0.045 \\
(0.051)\end{array}$ \\
\hline Indian & $\begin{array}{c}-0.085^{* *} \\
(0.031)\end{array}$ & $\begin{array}{c}0.032 \\
(0.039)\end{array}$ & $\begin{array}{r}0.063^{*} \\
(0.040)\end{array}$ & $\begin{array}{c}0.034 \\
(0.040)\end{array}$ & $\begin{array}{c}-0.004 \\
(0.043)\end{array}$ & $\begin{array}{l}-0.005 \\
(0.044)\end{array}$ \\
\hline Pakistani and Bangladeshi & $\begin{array}{c}-0.016 \\
(0.023)\end{array}$ & $\begin{array}{c}0.024 \\
(0.025)\end{array}$ & $\begin{array}{c}0.022 \\
(0.028)\end{array}$ & $\begin{array}{c}0.077^{* *} \\
(0.032)\end{array}$ & $\begin{array}{c}0.013 \\
(0.031)\end{array}$ & $\begin{array}{c}0.011 \\
(0.031)\end{array}$ \\
\hline Black or Black British & $\begin{array}{r}0.058^{*} \\
(0.033)\end{array}$ & $\begin{array}{l}0.107^{* * *} \\
(0.033)\end{array}$ & $\begin{array}{l}0.138^{* * *} \\
(0.037)\end{array}$ & $\begin{array}{l}0.134^{* * * *} \\
(0.040)\end{array}$ & $\begin{array}{c}0.055 \\
(0.038)\end{array}$ & $\begin{array}{c}0.054 \\
(0.039)\end{array}$ \\
\hline Other Ethnic group (inc Chinese,Other) & $\begin{array}{c}0.000 \\
(0.041)\end{array}$ & $\begin{array}{c}-0.019 \\
(0.039)\end{array}$ & $\begin{array}{l}-0.010 \\
(0.049)\end{array}$ & $\begin{array}{c}-0.000 \\
(0.065)\end{array}$ & $\begin{array}{c}0.049 \\
(0.067)\end{array}$ & $\begin{array}{c}0.043 \\
(0.068)\end{array}$ \\
\hline $\begin{array}{l}\mathbb{E}[\operatorname{Pr}(\text { overweight } \cup \text { obese }) \mid x] \\
\mathrm{N}\end{array}$ & $\begin{array}{r}0.199 \\
10,714\end{array}$ & $\begin{array}{r}0.174 \\
11,115\end{array}$ & $\begin{array}{l}0.159 \\
8.942\end{array}$ & $\begin{array}{l}0.240 \\
8.408\end{array}$ & $\begin{array}{l}0.192 \\
6.985\end{array}$ & $\begin{array}{l}0.193 \\
6.985\end{array}$ \\
\hline
\end{tabular}

Note: $* * *$ and $* * *$ denote statistical significance it $10 \%, 5 \%$ and $1 \%$ respectively. The outcome in each column is whether or not a child is overweight, defined using the the IOTF cutoffs (Table A1). The effects reported are marginal effects obtained after estimating Equation 4 fixing the independent variables at their sample mean. The MCS data do not contain parents' BMI at age 14, so columns 5 and 6 use BMI from age 11 or as predicted to define obesity. All observations are adjusted for the probability of attrition and being sampled, see (Hansen et al., 2014). The omitted categories are income: highest quintile; parents' education: no qualifications; ethnicity: white. Female is an indicator of whether a child is female. Not all healthy behaviours on which we have measures are available at all ages so each columns include those that are. Appendix Table A6(a) describes how indicators of healthy behaviours were constructed. $\mathbb{E}[\operatorname{Pr}($ overweight $) \mid \boldsymbol{x}]$ represents estimated the conditional expectation of a child being overweight. The main parent is the mother for over $99 \%$ of children at 9 months. Ns differ across columns because of missing data. 